RAUL MIGUEL FREITAS DE OLIVEIRA

\title{
CONCESSÃO FLORESTAL: EXPLORAÇÃO SUSTENTÁVEL DE FLORESTAS PÚBLICAS POR PARTICULAR
}

FACULDADE DE DIREITO DA UNIVERSIDADE DE SÃO PAULO SÃO PAULO 
RAUL MIGUEL FREITAS DE OLIVEIRA

\section{CONCESSÃO FLORESTAL: EXPLORAÇÃO SUSTENTÁVEL DE FLORESTAS PÚBLICAS POR PARTICULAR}

Tese apresentada como exigência parcial para obtenção do título de Doutor em Direito do Estado, sob orientação da Professora Titular Maria Sylvia Zanella Di Pietro

FACULDADE DE DIREITO DA UNIVERSIDADE DE SÃO PAULO SÃO PAULO 
À Juliana, amor e apoio incondicional na caminhada;

Aos "piccoli" Enrico e Beatrice, que resistiram bravamente à minha ausência;

E ao Augusto, cujo rostinho ainda não conheço pessoalmente. 


\section{AGRADECIMENTOS}

Agradeço à Professora Titular Maria Sylvia Zanella Di Pietro, paradigma de competência e de cuidado com as pessoas, por me acolher como seu orientado, confiar em minha capacidade e pela diuturna atenção.

Ao Professor Doutor Floriano Peixoto de Azevedo Marques Neto e Professor Doutor Fernando Dias Menezes de Almeida, pela compreensão de minhas dificuldades e limitações, além dos preciosos apontamentos no exame de qualificação que me auxiliaram na busca do aprimoramento deste trabalho.

Aos colegas de trabalho e estudo, pela ajuda e amizade. 


\section{RESUMO}

Esta tese tem por objeto a análise da concessão florestal, instrumento de outorga do uso de florestas públicas em caráter privativo ao particular.

Por tratar-se de uma relação jurídica, a análise é detida nos seus elementos componentes, que são basicamente o objeto, partes e regramento jurídico específico, comparando-a com outras espécies de concessão, como a concessão de serviço público e a concessão de uso de bem público.

Iniciando-se pelo estudo da tutela jurídica da floresta, uma vez que a concessão florestal também é instrumento de sua proteção, perpassa-se pelo delineamento da concessão e modelos de gestão de florestas públicas em outros países, para se alcançar o ponto principal que é a análise das regras da Lei $n^{\circ} 11.284$, de 02 de março de 2006, marco regulatório da gestão de florestas públicas brasileiras.

A conclusão procura realçar, dentre outros aspectos, a existência de uma efetiva política pública de gestão das florestas sob o domínio do poder público, erigida sobre o princípio constitucional do desenvolvimento sustentável do meio ambiente.

Palavras-chave: Bem público. Florestas. Uso privativo de bem público pelo particular. Gestão florestal. Uso sustentável da floresta pública. Princípio do desenvolvimento sustentável. Concessão de uso. Concessão Florestal. 


\section{RÉSUMÉ}

L'objectif de cette thèse est l'analyse de la concession forestière, instrument qui accord l'utilisation des forêts publiques en caractère privatif au particulier.

Se traitant d'une relation juridique, l'analyse est donc retenue dans ses éléments composants, qui sont essentiellement l'objet, les parties et le règlement juridique spécifique, en la comparant ainsi avec d'autres types de concession, telle que la concession du service publique et la concession d'utilisation de bien publique.

L'étude commence par la tutelle juridique de la forêt, une fois que la concession forestière est également un outil de sa propre protection, en passant par le délinéament de la concession et par les modèles de gestion des forêts publiques dans d'autres pays, afin d'atteindre le point principal qui est l'analyse des règles de la Loi n 11.284, du 2 mars 2006, borne réglementaire de la gestion des forêts publiques au Brésil.

La conclusion vise à souligner, entre autres choses, l'existence d'une effective politique publique de gestion des forêts sous le contrôle du gouvernement, érigée sur le principe constitutionnel du développement soutenable de l'environnement.

Mots-clés: Bien public. Forêts. L'usage privé des biens publics par l'individu. La gestion des forêts. L'utilisation durable de la politique forestière. Principe du développement soutenable. Concession d'utilisation et concession forestière. 


\begin{abstract}
This thesis focuses on the analysis of the forest concession an instrument which grants the use of public forests for private use.

From a legal perspective, the analysis is held in its component parts, which are basically the object, parties and specific legal rules, comparing it to other types of concessions, such as public service concession and authorization of use of public good.

The study begins with the legal protection of the forest, given the forest concession is equally a tool of its own protection, and one goes by the concession outline and the management models of public forests in other countries, in order to achieve the main point, which is the analysis of the rules of Law No. 11,284, from 02 March 2006, reglementary limit of public forests management in Brazil.

The conclusion seeks to highlight, among other aspects, the existence of an effective public policy for forest management under the control of government, built on the constitutional principle of sustainable development of the environment.
\end{abstract}

Keywords: Public good. Forests. Private use of public property by the individual. Forest management. Sustainable use of public forest. Principle of sustainable development. Consent of use. Forest Concession. 


\section{ÍNDICE}

CAPÍTULO 1 - DISCIPLINA JURÍDICA DA FLORA ............................................ 14

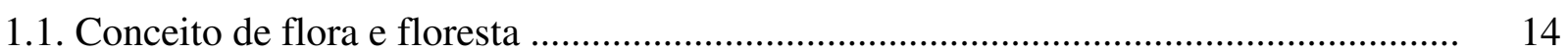

1.2. Natureza jurídica da flora ............................................................................. 18

1.2.1 Flora como um elemento do meio ambiente natural .......................................... 18

1.2.2 Natureza jurídica do meio ambiente ecologicamente equilibrado ........................ 20

1.2.2.1 Bem ambiental com natureza jurídica diversa de bem público ................ 22

1.2.2.2 Bem ambiental com natureza de bem público ........................................ 24

1.2.2.3 Natureza jurídica do bem ambiental ....................................................... 29

1.2.3 Conclusão quanto a natureza jurídica da flora ................................................... 33

1.3 Evolução histórica da tutela legal do patrimônio florestal .......................................... 33

1.4 Bloco normativo de tutela do patrimônio florestal ....................................................... 40

1.5 Classificação das florestas e demais formas de vegetação brasileiras ........................... 44

1.5.1 Classificaçãa técnica ..................................................................................... 44

1.5.2 Classificações jurídicas legais e doutrinárias ..................................................... 46

1.6 Competências em matéria florestal ........................................................................ 50

1.7 Instrumentos de proteção da flora previstos na legislação .......................................... 52

1.7.1 Da proteção de um elemento do ecossistema para a proteção dos biomas ........... 52

1.7.2 Espaços territoriais especialmente protegidos .................................................. 54

1.7.3 Área de preservação permanente ...................................................................... 57

1.7.3.1 Conceito legal e evolução da disciplina no Código Florestal .................. 57

1.7.3.2 Tipologia das áreas de preservação permanente …….............................. 58

1.7.3.3 Normas regulamentares e a supressão total ou parcial da área de 61 preservação permanente

1.7.3.4 Área de preservação permanente: características e principais discussões 69

1.7.4 Reserva florestal legal ............................................................................ 76

1.7.5 Servidão florestal e cota de reserva florestal ...................................................... 85

1.7.6 Área de inclinação média ........................................................................ 88

1.7.7 Proibição individualizada de corte ..................................................................... 89

1.7.8 Unidades de conservação ................................................................................. 91

1.7.8.1 Conceito e evolução ........................................................................ 91 
1.7.8.2 Categorias de unidades de conservação

1.7.8.3 Criação, modificação, funcionamento e extinção de unidades de 100 conservação

1.7.8. 4 Outras formas de proteção da flora ...................................................... 103

1.7.8.4.1 Reserva da biosfera ........................................................... 104

1.7.8.4.2 Ilhas oceânicas e ilhas lacustres e de rios ................................ 104

1.7.8.4.3 Hortos florestais .................................................................. 105

1.7.8.4.4 Jardins zoológicos .............................................................. 106

1.7.8.4.5 Paralelograma de cobertura florestal ..................................... 106

1.7.8.4.6 Zona de preservação da vida silvestre ................................... 106

1.7.8.4.7 Áreas Especiais de interesse turístico e locais de interesse 107 turístico

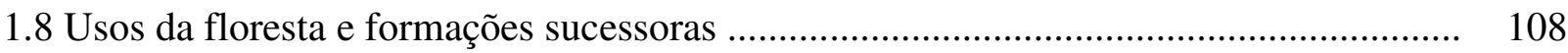

1.8.1 Regime de manejo florestal sustentável .......................................................... 110

1.8.2 Regime de supressão a corte raso de florestas e formações sucessoras para uso 111 alternativo do solo

1.8.3 Utilização de matéria-prima florestal e obrigação de reposição florestal .....

CAPÍTULO 2 - DELINEAMENTO DAS CONCESSÕES …..................................... 113

2.1. Considerações sobre a concessão em sentido amplo ................................................ 113

2.2. Classificações de concessão ...................................................................................... 116

2.3 Semelhanças entre as concessões de serviço público e de uso de bem público .............. 120

2.4 Diferenças entre as concessões de serviço público e de uso de bem público ................. 129

2.5 Breve comparação da concessão florestal com as demais modalidades ........................ 135

CAPÍTULO 3 - FLORESTAS PÚBLICAS NO MUNDO …...................................... 138

3.1 Anotações sobre a gestão de florestas públicas no mundo ......................................... 138

3.2 Antecedentes e marco regulatório da gestão de florestas públicas brasileiras ............... 149

3.3 Princípios da gestão de florestas públicas para produção sustentável ........................... 155

CAPÍTULO 4 - GESTÃO DAS FLORESTAS PÚBLICAS ….................................. 158

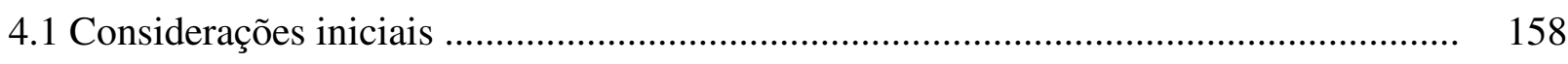

4.2 Gestão direta da floresta nacional, estadual e municipal ........................................... 159

4.3 Gestão pela outorga da exploração da floresta pública a comunidades locais ............... 163

4.3.1 Conceito de comunidades locais ................................................................. 163 
4.3.2 Criação de reservas extrativistas e reservas de desenvolvimento sustentável ...... 167

4.3.3 Concessões de uso para projetos de assentamento florestal e de outras naturezas 173

4.3.4 Outras formas de outorga às comunidades locais .......................................... 174

4.3.5 Concessão florestal para comunidades locais ............................................... 176

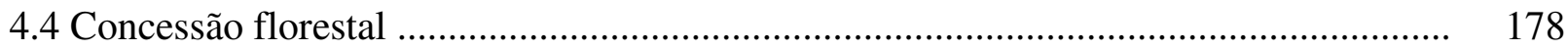

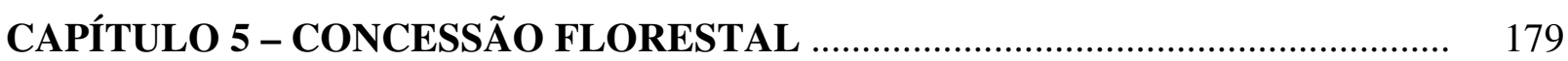

5.1 Delimitação do conceito e natureza jurídica da concessão florestal ............................. 179

5.2 Medidas prévias à licitação para concessão florestal .................................................. 185

5.2.1 Formação do Cadastro Nacional de Florestas Públicas - CNFP ......................... 189

5.2.2 Elaboração de Plano Anual de Outorga Florestal - PAOF ............................... 192

5.2.3 Licenciamento Ambiental .......................................................................... 198

5.3 Autorização legislativa prévia ............................................................................. 207

5.3.1 Autorização legislativa na transferência de propriedade de bens públicos ........... 207

5.3.2 Autorização legislativa na concessão de uso de bens públicos .............................. 209

3.5.3 Autorização legislativa do Congresso Nacional .............................................. 212

5.4 Procedimento da licitação para concessão florestal ................................................ 216

5.4.1 Fase de publicação do edital ........................................................................ 218

5.4.1.1 Disponibilização na rede mundial de computadores ............................... 219

5.4.1.2 Direito a informação e acesso aos documentos da licitação ..................... 219

5.4.1.3 Audiência pública obrigatória .............................................................. 220

5.4.1.4 Manifestação técnica de conveniência da concessão florestal .................. 223

5.4.1.5 Florestas públicas elegíveis à concessão florestal ................................... 225

5.4.1.6 Modalidade de licitação e impossibilidade de declaração de 226 inexigibilidade

5.4.1.7 Prazo de publicação do aviso de edital .................................................. 228

5.4.1.8 Local de realização dos atos da licitação ............................................... 229

5.4.1.9 Requisitos mínimos do edital .............................................................. 230

5.4.1.10 Universo de licitantes ......................................................................... 237

5.4.2 Fase de habilitação ....................................................................................... 243

5.4.3 Fase de classificação das propostas e julgamento ............................................ 244

5.5 Regramento do contrato de concessão florestal ....................................................... 247

5.5.1 Prévia existência do Plano de Manejo Florestal Sustentável - PMFS ................. 247

5.5.2 Cláusulas obrigatórias do termo contratual .................................................. 248 
5.5.3 Direitos e obrigações do concessionário

5.5.4 Prazo da concessão florestal ........................................................................ 255

5.5.5 Regime econômico financeiro da concessão florestal .................................... 257

5.5.5.1 Formação do preço florestal ............................................................. 258

5.5.5.2 Reajuste do preço florestal ............................................................. 262

5.5.5.3 Fixação de bônus ......................................................................... 262

5.5.5.4 Inadimplência do preço florestal ...................................................... 263

5.5.5.5 Salvaguardas da concorrência .......................................................... 264

5.5.5.6 Financiamento garantido por direitos emergentes .............................. 265

5.5.6 Gestão do contrato de concessão florestal ...................................................... 266

5.5.7 Extinção da concessão florestal ................................................................ 268

5.6 Fundo e repartição de receitas ................................................................................. 267

5.6.1 Repartição de receitas da concessão florestal ................................................... 273

5.6.2 Fundo Nacional de Desenvolvimento Florestal - FNDF ................................... 274

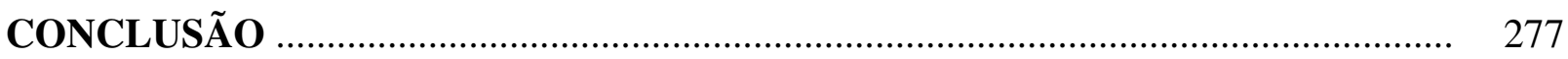

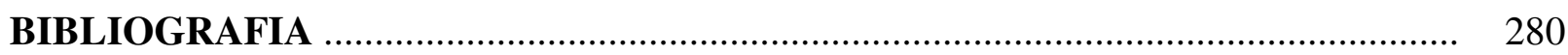




\section{INTRODUÇÃO}

A Lei $\mathrm{n}^{\mathrm{o}}$ 11.284, de 02 de março de 2006, trouxe a lume a gestão das florestas públicas brasileiras, assunto até então ausente no ordenamento jurídico brasileiro, com a completude com que é atualmente tratado.

Dentre os instrumentos de gestão da floresta pública, tal lei inovou por introduzir uma nova espécie de concessão de uso de bem público, a concessão florestal, que é o objeto central desta tese.

Com a pretensão de se alcançar a plena compreensão desta nova modalidade de contrato, foi adotada uma forma de exposição que privilegiou o objeto da relação jurídica, a descrição de outras relações semelhantes, o estado da arte da gestão de florestas públicas no mundo e, finalmente, o detalhamento do regramento específico da matéria na nova lei.

O primeiro capítulo consiste na exposição da disciplina jurídica da flora brasileira, em que se demonstra os conceitos basilares do Direito Florestal, a descrição das formações florestais, os instrumentos legais de sua proteção, entre outros aspectos.

Trilhou-se, portanto, nesse capítulo, uma análise crítica das normas jurídicas mais relevantes de tratamento desse bem ambiental, cujo conhecimento e entendimento não é tarefa fácil, na medida em que essas normas se encontrarem dispersas em diversos diplomas legais.

No segundo capítulo, a preocupação foi a de esmiuçar a relação jurídica da concessão em suas duas espécies básicas, a concessão de serviço público e a concessão de uso de bem público, para, ao final, construir-se demonstração ampla de que a concessão florestal é subespécie desta última.

No terceiro capítulo, o foco dirigiu-se ao contraponto entre as anotações sobre a gestão de florestas públicas no mundo e os antecedentes e marco regulatório da gestão de florestas públicas brasileiras para, só posteriormente, se concluir com o reconhecimento de princípios da gestão sustentável de florestas públicas que, apesar de construídos no ambiente internacional, foram albergados no ordenamento pátrio.

Por causa da complexidade da Lei Geral de Gestão de Florestas Públicas, que minudencia outros instrumentos de outorga do uso sustentável das florestas públicas ao particular, tais como a gestão direta de floresta nacional, estadual e municipal, a concessão de direito real de uso às comunidades locais, por meio da criação de reservas extrativistas e 
reservas de desenvolvimento sustentável, concessões de uso para projetos de assentamento florestal, dentre outros, inarredável a estruturação do quarto capítulo para o estudo particularizado de tais instrumentos.

No quinto e último capítulo, a atenção foi depositada exclusivamente na concessão florestal, na sua conceituação, definição da natureza jurídica, análise das fases do procedimento de licitação e regramento do contrato administrativo em si.

No objeto central do trabalho, grande importância foi conferida ao exame comparativo da normatização da licitação para concessão florestal, e do contrato dela decorrente, com as regras gerais da licitação e contratação públicas, tanto para aquisição de produtos, serviços e obras públicas, quanto para as concessões de serviço público.

Percebeu-se, ao fim do trajeto, que a concessão florestal possui a particularidade de ter incorporado em seu regramento uma série de institutos da concessão de serviço público, pela necessidade de melhor gerir o manejo florestal sustentável, espécie de uso privativo de bem público.

Da sucinta exposição, demonstrou-se que a tônica perseguida nesta tese foi a de se minudenciar a concessão florestal nos seus aspectos basilares, confirmando tratar-se de uma efetiva política pública de gestão do imenso patrimônio florestal, atrelada ao objetivo básico de efetivação do princípio do desenvolvimento sustentável, consagrado no artigo 225, da Constituição Federal. 


\section{CAPÍTULO 1 \\ DISCIPLINA JURÍDICA DA FLORA BRASILEIRA}

\subsection{Conceito de flora e floresta}

A proteção ou preservação da flora e, consequentemente, das florestas, encontra-se explicitada no texto da Constituição Federal em dois dispositivos, o inciso VII, do artigo 23 e o inciso VII, do $\S 1^{\circ}$, do artigo 225 , nos seguintes termos:

Art. 23 É competência comum da União, dos Estados, do Distrito Federal e dos Municípios:

(...)

VII - preservar as florestas, a fauna e a flora;

(...)

Art. 225 Todos têm direito ao meio ambiente ecologicamente equilibrado, bem de uso comum do povo e essencial à sadia qualidade de vida, impondo-se ao poder público e à coletividade o dever de defendê-lo e preservá-lo para as presentes e futuras gerações.

$\S 1^{\circ}$ Para assegurar a efetividade desse direito, incumbe ao Poder Público:

(...)

VII - proteger a fauna e a flora, vedadas, na forma da lei, as práticas que coloquem em risco sua função ecológica, provoquem a extinção de espécies ou submetam os animais a crueldade. (grifo nosso)

$\mathrm{Na}$ redação do inciso VII, do artigo 23 supra transcrito, denota-se que o legislador constitucional utilizou as palavras "florestas" e "flora", possibilitando dúvida quanto aos seus significados, ou seja, se esses termos designam ou não um mesmo objeto da preservação decorrente do exercício da competência material dos entes da federação.

A doutrina é profícua nessa discussão, tanto que, para Wellington Pacheco Barros $^{1}$, "Flora é o conjunto de espécies vegetais que compõem a cobertura vegetal de uma determinada área" enquanto "florestas, consideradas em si mesmas, são áreas com alta densidade de árvores”. Para tal doutrinador, ainda, “à uma pequena floresta também se dá o nome de mata".

Paulo Affonso Leme Machado ${ }^{2}$ cita que a Medida Provisória $n^{\circ}$ 2.16667/2001 define floresta como "vegetação cerrada constituída de árvores de grande porte, cobrindo grande extensão de terreno”. Entretanto, não se localiza no texto da última publicação da aludida norma essa definição.

${ }^{1}$ Curso de Direito Ambiental, $2^{\mathrm{a}}$ ed., São Paulo: Atlas, 2008. p. 141-142

${ }^{2}$ Direito Ambiental Brasileiro, $15^{\mathrm{a}}$ ed.., São Paulo: Malheiros, 2007. p. 735 
Celso Antonio Pacheco Fiorillo ${ }^{3}$ entende que os termos flora e floresta não possuem o mesmo significado na Constituição Federal, pois "o primeiro é coletivo que engloba o conjunto de espécies vegetais de uma determinada região", sendo a floresta "um dos conteúdos do continente flora".

Lembra o doutrinador que o Anexo I, da Portaria $\mathrm{n}^{\circ}$ 486-P do Instituto Brasileiro do Desenvolvimento Florestal - IBDF definia floresta como "formação arbórea densa, de alto porte, que recobre área de terra mais ou menos extensa”.

O Instituto Brasileiro do Desenvolvimento Florestal - IBDF era uma autarquia, vinculada ao Ministério da Agricultura, que foi criada pelo Decreto-Lei $\mathrm{n}^{\circ} 289$, de 28 de fevereiro de 1967 e extinta pela Medida Provisória $n^{\circ}$ 28, de 15 de janeiro de 1989, convertida na Lei $\mathrm{n}^{\circ}$ 7.732, de 14 de fevereiro de 1989.

$\mathrm{Na}$ definição de Eliana Goulart Leão de Faria", flora é um "conjunto das espécies vegetais de uma determinada localidade" e "floresta é uma espécie, caracterizada por vegetação densa, com árvores de grande porte, que cobre extensas áreas”.

Luís Paulo Sirvinskas 5 conceitua flora como "conjunto de plantas de uma região, de um país ou de um continente" e ressalta seu caráter de ecossistema sustentado, composto pela interação entre seres vivos, fatores energéticos e materiais que a compõem.

O mesmo doutrinador, para explicar floresta, refere-se ao conceito de Luiz Regis Prado ${ }^{6}$, assim: "um tipo de vegetação, formando um ecossistema próprio, onde interagem continuamente os seres vivos e a matéria orgânica e inorgânica presentes", conceito este que se assemelha com aquele por ele usado para definir a flora.

Para José Augusto Delgado "o conceito jurídico de floresta está concentrado na afirmação de que é uma formação vegetal geralmente densa, em que predominam as árvores ou espécies lenhosas de grande porte".

Teresa Cristina de Deus ${ }^{8}$, entende que flora é gênero do qual a floresta é uma espécie, ressaltando em relação à primeira a sua função ecológica:

\footnotetext{
${ }^{3}$ Curso de Direito Ambiental Brasileiro, $9^{\text {a }}$ ed., São Paulo: Saraiva, 2008. p. 113

${ }^{4}$ O Código Florestal brasileiro e seu aperfeiçoamento, in DALLARI, Adilson Abreu. FIGUEIREDO, Lucia Valle, Temas de Direito Urbanístico, São Paulo: RT, 1987. p. 74 - 106.

5 Manual de Direito Ambiental, 6 a ed., São Paulo: Saraiva, 2008. p. 376

${ }^{6}$ Crimes contra o ambiente, São Paulo, Revista dos Tribunais, 1998. p. 81

7 A proteção jurídica das florestas tropicais e a ação de desapropriação indireta. Doutrina e jurisprudência, in Anais do $3^{\circ}$ Congresso Internacional de Direito Ambiental, 30 de maio a 02 de junho de 1999: a proteção jurídica das florestas tropicais, organizado por Antônio Hermann de Vasconcelos e Benjamin, São Paulo: IMESP, 1999. p. 250

${ }^{8}$ Tutela da flora em face do direito ambiental brasileiro, São Paulo: Juarez de Oliveira, 2003. p. 17
} 
(...) o vocábulo flora deve ser conceituado como o "conjunto das espécies vegetais de um país ou de determinada localidade" onde cada planta tem uma importância fundamental na biocenose, participando com maior ou menor intensidade de diferentes cadeias tróficas. Esse conceito é coletivo, pois engloba florestas, caatingas, cerrados, brejos, mangues, vegetações forrageiras nativas que cobrem os campos naturais, etc. Em outras palavras, a flora é composta de todas as formas de vegetação que, de uma forma ou de outra, são úteis à terra que revestem e mantêm o equilíbrio de determinado ecossistema. (grifo nosso)

Na mesma linha, para Américo Luís Martins da Silva ${ }^{9}$ realça as interações biológicas existentes na floresta:

Floresta, bosque ou mata (...) é um ecossistema complexo, no qual as árvores são a forma vegetal predominante que protege o solo contra o impacto direto do sol, dos ventos e das precipitações. (...) Portanto, por floresta deve-se entender qualquer sociedade de seres vivos (tanto vegetal como animal) na qual os habitantes mais importantes são as árvores; mais importantes e não necessariamente os mais numerosos (...) (grifo nosso)

José Afonso da Silva ${ }^{10}$ destaca que o termo flora é sempre usado no singular, enquanto floresta é usado no plural, o que reafirma o fato do primeiro dever ser entendido como um coletivo referente "ao conjunto de espécies vegetais do país ou de determinada localidade", enquanto o segundo, a floresta, "é um tipo de flora" que se diferencia dos outros tipos por possuir uma característica própria de ser constituída por "vegetação razoavelmente densa e elevada" compreendendo "formações de grande ou pequena extensão".

De todas as definições perfiladas, em relação ao termo flora é inegável que deve ser compreendido como um coletivo, um conjunto de espécies vegetais ou plantas.

Portanto, tal coletivo ou conjunto é formado por um objeto bem definido: plantas ou espécies vegetais.

Além do elemento objetivo, no conceito de flora deve-se considerar também o elemento espacial: sempre refere-se a determinada região, área, país ou continente.

A definição completa de flora é, assim, de uma coletividade de plantas de determinado território, daí seu caráter também genérico.

Em relação a floresta, a conclusão é que as definições referem-se ao fato dela ser, em relação a flora, uma espécie. Se a flora é conjunto de vegetação de

\footnotetext{
${ }^{9}$ Direito do Meio Ambiente e dos Recursos Naturais, Vol. 2, São Paulo: Revista dos Tribunais, 2005. p. 3738

${ }^{10}$ Direito Ambiental Constitucional, $3^{\mathrm{a}}$ ed., São Paulo: Malheiros Editores, 2000. p.153
} 
determinado território, a floresta é um dos tipos de vegetação que a compõem. Por exemplo, são evidentes as diferenças entre uma floresta e a caatinga, cada qual com suas peculiaridades.

O próprio Código Florestal, Lei $n^{\circ}$ 4.771, de 15 de setembro de 1965, em seu artigo $1^{\circ}$ confirma tal fato, pois sua redação é a seguinte: "Art. $1^{\circ}$ As florestas existentes no território nacional e as demais formas de vegetação (...)" (grifo nosso), ou seja, as florestas são uma espécie de vegetação entre tantas outras existentes no território nacional.

$\mathrm{Na}$ conceituação de floresta também são adotados elementos descritivos, ou seja, a floresta é:

a) um tipo de vegetação cuja característica principal seria possuir alta densidade de árvores, geralmente de grande porte;

b) tais árvores serem os indivíduos mais importantes, sob o ponto de vista biológico;

c) tal vegetação estar sobre um terreno razoavelmente extenso.

Mesmo tecnicamente se denota que o conceito de floresta é descritivo, conforme confirma a definição abaixo da Fundação Instituto Brasileiro de Geografia e Estatística - $\mathrm{IBGE}^{11}$ :

Floresta: termo semelhante à mata no sentido popular, tem conceituação bastante diversificada, mas firmada cientificamente como sendo um conjunto de sinúsias ${ }^{12}$ dominado por fanerófitos de alto porte, com quatro estratos bem definidos (herbáceo, arbustivo, arvoreta, arbóreo). Além destes parâmetros, acrescenta-se o sentido de altura, para diferenciá-las das outras formações lenhosas campestres. Assim sendo, uma formação florestal apresenta dominância de duas subformas de vida de fanerófitos: macrofanerófitos, com alturas variadas de 30 e $50 \mathrm{~m}$, e mesofanerófitos, cujo porte situa-se entre 20 e $30 \mathrm{~m}$ de altura.

Ainda, tanto para a flora, quanto para a floresta, há definições doutrinárias que realçam o fato de se constituírem ecossistemas complexos e sustentados, aspecto este de suma importância, por alargar a definição para uma idéia mais complexa, de interações biológicas entre elementos orgânicos e inorgânicos, seres vivos vegetais ou não, componentes de tal realidade.

11 Manual Técnico da Vegetação Brasileira, Rio de Janeiro: IBGE, 1992, disponível em: http://biblioteca.ibge.gov.br/visualizacao/monografias/GEBIS\%2020RJ/ManuaisdeGeociencias/Manual\%20 Tecnico\%20da\%20Vegetacao\%20Brasileira\%20n.1.pdf Acesso em: 17.05.2009

${ }^{12} \mathrm{O}$ mesmo manual define "Sinúsia - termo que significa um conjunto de plantas de estrutura semelhante, integrada por uma mesma forma de vida ecologicamente homogênea (Du Rietz, 1957)”. 
Portanto, a definição para tais termos deve ser doutrinária, até porque não se encontra definição legal atualizada, informação esta também compartilhada por Américo Luís Martins da Silva ${ }^{13}$ : "Para conseguirmos determinar um conceito jurídico de floresta temos que recorrer à doutrina, já que a legislação nacional é omissa, aí incluindo o próprio Código Florestal (...)".

E mais, o doutrinador defende que cada tipo de floresta deve possuir sua própria definição jurídica doutrinária composta, porém, de elementos não jurídicos, das ciências biológicas, que descrevem as características de cada uma delas.

Sem qualquer espécie de demérito a tal opinião, é relevante observar que a definição jurídica doutrinária de flora passa, necessariamente, pela idéia de coletividade, conjunto de espécies vegetais, nele se incluindo os vários tipos de florestas.

A floresta, por sua vez, pode ser conceituada como uma espécie de flora caracterizada por ser formada por razoável quantidade de árvores, em determinado território, desempenhando esses indivíduos (árvores) uma função primordial no ecossistema ao qual pertencem.

\subsection{Natureza jurídica da flora.}

\subsubsection{Flora como um elemento do meio ambiente natural.}

No artigo 225, a Constituição Federal inaugurou um capítulo próprio para dispor sobre o meio ambiente como um direito social. Segundo a redação do "caput" do aludido dispositivo constitucional, o meio ambiente "ecologicamente equilibrado" é "bem de uso comum do povo" essencial à sadia qualidade de vida, por isso devendo o poder público e a coletividade preservá-lo às presentes e futuras gerações.

Ao explicar o conteúdo do dispositivo mencionado, José Afonso da Silva ${ }^{14}$ ressalta que o meio ambiente deve ser entendido como um bem jurídico qualificado pelo equilíbrio ecológico que é essencial a uma vida sadia, conferindo a tal objeto de direito uma natureza jurídica especial, entendimento este que conta com a concordância de Maria Sylvia Zanella Di Pietro ${ }^{15}$.

\footnotetext{
${ }^{13}$ Op. cit., p. 40

${ }^{14}$ Op. cit., p. $80-81$

${ }^{15}$ Polícia do meio ambiente, Revista Forense, vol. 317, Rio de Janeiro: Forense, 1992. p. 179-187
} 
Antecedendo a explicação dessa natureza jurídica especial, merece nota que, antes mesmo da nova ordem constitucional, uma conceituação para a expressão "meio ambiente" foi inserida no inciso I, do artigo $3^{\circ}$, da Lei $n^{\circ} 6.938$, de 31 de agosto de 1981 (Lei da Política Nacional do Meio Ambiente), do seguinte modo: “conjunto de condições, leis, influências e interações de ordem física, química e biológica, que permite, abriga e rege a vida em todas as suas formas".

O exame dessa definição legal demonstra que ela expressa apenas o meio ambiente natural, por isso não sendo adequada a atual concepção do mesmo, podendo ser considerada incompleta.

Isto porque, uma conceituação jurídica mais abrangente para o meio ambiente perpassa pelas divisões alinhavadas por vários doutrinadores, divisões estas denominadas de elementos componentes ou aspectos.

Para Celso Antonio Pacheco Fiorillo ${ }^{16}$, o meio ambiente possui quatro aspectos significativos: o natural, o artificial, o cultural e o do trabalho; assim definidos para que se "facilitar a identificação da atividade degradante e do bem imediatamente agredido".

Esta mesma classificação é adotada em obra conjunta com Marcelo Abelha Rodrigues $^{17}$, em que ambos explicam que a divisão do conceito de meio ambiente em tais aspectos não visa o "esquartejamento do conceito", mas “apenas (...) dizer que as agressões ao meio ambiente (...) podem se processar sob os diversos flancos que o meio ambiente admite existir".

Ou seja, a divisão nos citados aspectos, no modo de ver desses doutrinadores, contribui não só para a melhor compreensão do meio ambiente, como também para a sua melhor proteção, em todos os seus aspectos componentes. No mesmo viés é a doutrina de Luis Paulo Sirvinskas ${ }^{18}$, Teresa Cristina de Deus ${ }^{19}$, entre outros.

Para José Afonso da Silva ${ }^{20}$ o meio ambiente é composto por "elementos naturais, artificiais e culturais que propiciem o desenvolvimento equilibrado da vida em todas as suas formas”, devendo ser dispensada atenção também ao meio ambiente do trabalho que "se insere no artificial, mas digno de tratamento especial", em razão da particular disposição do artigo 200, inciso VIII, da Constituição Federal.

${ }^{16}$ Curso de direito ambiental brasileiro, São Paulo: Saraiva, 2008. p. 20

${ }^{17}$ Manual de direito ambiental e legislação aplicável, São Paulo: Max Limonad, 1999. p. 54-55

${ }^{18}$ Manual de direito ambiental, São Paulo: Saraiva, 2008. p. 38

${ }^{19}$ Tutela da flora em face do direito ambiental brasileiro, São Paulo: Editora Juarez de Oliveira, 2003. p. 37

${ }^{20}$ Op. cit., p. 20-24 
O meio ambiente natural, assim, pode ser conceituado como aquele ambiente composto pela relação entre os seres vivos e seu meio, a flora, a fauna, a atmosfera, a água, ou seja, aquelas relações explicitadas no conceito inserto na Lei da Política Nacional do Meio Ambiente, portanto, em princípio, sem a ação antrópica.

Ao contrário, o meio ambiente artificial é aquele que sobrevém, de alguma forma, da ação humana, nele podendo ser introduzido também parte do meio ambiente cultural e o meio ambiente do trabalho.

Tal meio ambiente artificial pode ser conceituado em sentido estrito como aquele que é composto pelo espaço urbano, tanto pelas edificações, quanto pelos equipamentos públicos.

Parte do meio ambiente cultural e o meio ambiente do trabalho podem ser entendidos como meio ambiente artificial, porém decorrentes de ação antrópica direcionada a determinadas finalidades específicas.

Se a ação antrópica é voltada a finalidades com valor especial, tais como as tradições e identidade dos povos, caracteriza-se o meio ambiente cultural, composto pelo denominado patrimônio histórico, artístico, arqueológico, paisagístico, turístico. Denota-se, apenas, que o elemento paisagístico pode ou não ser produto de ação do ser humano.

E, finalmente, a ação antrópica no ambiente no qual são desenvolvidas as atividades do trabalho humano, buscando-se a preservação da saúde e qualidade de vida, caracteriza o meio ambiente do trabalho.

Esta primeira abordagem do conceito de meio ambiente, pela divisão de seus elementos ou aspectos, serve para se estruturar uma primeira idéia de suma importância, que a flora é parte componente do meio ambiente natural. Então, eis aí uma primeira contribuição para o contorno de sua natureza jurídica: trata-se de um elemento que compõe o conceito de meio ambiente natural.

Feita tal consideração inicial, fica claro que, para a melhor definição da parte, a flora, necessária uma delimitação mais precisa do todo, o meio ambiente ecologicamente equilibrado citado na Constituição Federal, conceito sobre o qual recaem inúmeras discussões, conforme adiante se expõe.

\subsubsection{Natureza jurídica do meio ambiente ecologicamente equilibrado.}

O debate na doutrina quanto à natureza jurídica do meio ambiente ecologicamente equilibrado se relaciona com a delimitação do sentido da expressão "bem 
de uso comum do povo" constante no texto do "caput", do artigo 225, da Constituição Federal.

No direito administrativo, tal expressão serve para designar uma das espécies de bens públicos, ao lado dos bens de uso especial e bens dominicais ou dominiais, seguindo a tradicional classificação do Código Civil brasileiro.

Diante desse sentido para a expressão, questiona-se se a natureza jurídica do meio ambiente ecologicamente equilibrado pode ser definida como bem público ou se há uma natureza jurídica própria, diferenciada.

Tal debate parece ser de somenos importância, entretanto, se relaciona com outra discussão, de âmbito maior, quanto a uma suposta insuficiência do direito administrativo para explicar os conceitos relativos às regras jurídicas ambientais, sendo que não são incomuns posicionamentos doutrinários que expressam tal opinião.

Por exemplo, para Paulo de Bessa Antunes ${ }^{21}$ parece "o Direito Administrativo é uma das principais fontes do Direito Ambiental”, entretanto, a relação entre eles seria "dramática”, pois, no direito administrativo “(...) a noção de interesse público está profundamente vinculada à defesa dos interesses do Estado enquanto estrutura burocraticamente organizada e não para a defesa dos interesses dos cidadãos considerados como comunidade, em face do Estado.”.

E mais, para ele "Em matéria ambiental, não se poderá deixar de fazer uma crítica aos conceitos tradicionais do Direito Administrativo, sob pena de que estes impeçam uma adequada proteção ao meio ambiente".

Em trilha semelhante defende Antônio Hermann Benjamin"22 que "O Direito Administrativo tradicional tem sido, ao mesmo tempo, a fonte primária para o progresso do Direito Ambiental e o maior óbice de seu desenvolvimento pleno.”.

Assim, discutir a natureza jurídica do bem ambiental, para depois definir a natureza jurídica de um de seus elementos, no caso presente a flora, por meio de uma organização das principais correntes doutrinárias, poderá contribuir para se demonstrar que as diferentes formas de se conceituar o bem ambiental não acarreta a diminuição da utilidade de um ou outro ramo do direito.

Um determinado grupo de doutrinadores defende que a natureza jurídica do meio ambiente ecologicamente equilibrado não se acomoda na dicotomia de direito público

\footnotetext{
${ }^{21}$ Direito Ambiental, Rio de Janeiro: Editora Lumen Juris, 1999. p. 89

${ }^{22}$ Os princípios do estudo de impacto ambiental como limites da discricionariedade administrativa, Revista Forense, 1992, n 317, jan./mar., Rio de Janeiro, p. 25-45
} 
e direito privado, ou seja, o "bem ambiental" não seria bem público ou bem privado e sim "bem difuso".

Outro grupo de doutrinadores entende que a natureza jurídica do bem ambiental é de bem público, porém não inserido entre os bens sobre os quais o Estado exerce o direito de propriedade, mas somente a gestão, pois tal bem ambiental é bem pertencente a todos, por isso não pode ser apropriado por ninguém, inclusive o próprio poder público.

Tanto num quanto noutro grupo o sentido que se confere à expressão "bem de uso comum do povo", que qualifica o bem ambiental na Constituição Federal, não se aproxima da idéia de que tal bem é apenas uma das espécies de bens públicos alinhavadas na doutrina tradicional civilista e administrativista.

Feitas tais considerações iniciais, caminha-se para a discussão dos conceitos construídos por cada um dos citados grupos de doutrinadores.

\subsubsection{Bem ambiental com natureza jurídica diversa de bem público.}

Para Paulo Affonso Leme Machado ${ }^{23}$ o artigo 225, da Constituição Federal, "deu nova dimensão ao conceito de meio ambiente como bem de uso comum do povo", não tendo eliminado o conceito antigo, mas ampliado-o em razão dos princípios da "função social e a função ambiental da propriedade como bases da gestão do meio ambiente, ultrapassando o conceito de propriedade privada e pública”.

Tal doutrinador não adota uma denominação específica para o bem ambiental, porém defende que sobre ele o Estado não exerce propriedade, tal como no bem público, mas apenas gestão.

Celso Antonio Pacheco Fiorillo ${ }^{24}$ defende que, após o advento da Constituição Federal de 1988, a dicotomia entre bem público e bem privado, baseada no critério diferenciador da propriedade do seu titular, proveniente do direito civil, foi suplantada por uma nova concepção, baseada num "novo bem, que não é público e não é privado: o bem difuso".

Para ele, o bem ambiental possui como titulares todas as pessoas, inclusive as gerações futuras, e não apenas um titular que sobre ele exerce o domínio, sendo, ainda, relevante a "somatória dos dois aspectos - bem de uso comum do povo e essencial à sadia

${ }^{23}$ Op. cit., p. 98 e 122

${ }^{24}$ Curso de Direito Ambiental Brasileiro, São Paulo: Saraiva, 2008. p. 69 
qualidade de vida - que se estrutura constitucionalmente o bem ambiental", que efetivamente diferencia o bem ambiental do bem público puro e simples.

Para Rui Carvalho Piva ${ }^{25}$ o "Bem ambiental é um valor difuso, imaterial ou material, que serve de objeto mediato a relações jurídicas de natureza ambiental.”. Ele também admite que é bem de uso comum do povo no sentido de não ter um titular pleno e individual de seu uso, uma vez que seria de todas as pessoas indistintamente.

Contudo, Rui Carvalho Piva ${ }^{26}$ faz a ressalva que seu entendimento deve ser compatibilizado com as demais normas constitucionais, particularmente a do artigo 20, da Constituição Federal, que prevê uma série de bens ambientais que comporiam o patrimônio específico da União.

Afora a menção ao entendimento de outros doutrinadores, que consideram que tal questão refere-se, em parte, à impropriedade redacional da Constituição Federal, o doutrinador defende conceito próprio do bem ambiental elevando, como elemento diferenciador, sua natureza imaterial e diferencia o conceito de bem ambiental dos conceitos de meio ambiente e de recursos ambientais.

Luciane Martins de Araújo Mascarenhas ${ }^{27}$ explora a idéia que a classificação do Código Civil teria "nítida conotação dominial e econômica", o que poderia não ser compatível com muitos recursos naturais que não são passíveis de apropriação individual. E, arremata a doutrinadora: "De fato, em uma análise ampla e global, não há como enquadrar os componentes do meio ambiente nos estreitos limites a que se refere o Código Civil. O meio ambiente não é um bem do Poder Público, nem privado, trata-se de bem pertencente a toda a coletividade".

Durval Salge Júnior $^{28}$ também defende que o bem ambiental deve ser incluído em categoria própria e diferenciada, em razão de sua natureza difusa, pois não se amolda na categoria de bem público ou privado. Diz ele: "Essa característica difusa confere ao bem ambiental especial força jurídica, posto que conferirá aos seus titulares as mais diversas medidas para possibilitar a vitaliciedade do instituto".

Também comunga de entendimento semelhante Paulo de Bessa Antunes ${ }^{29}$ para quem o bem ambiental merece classificação diversa do bem público e do bem

\footnotetext{
${ }^{25}$ Bem ambiental, São Paulo: Max Limonad, 2000. p. 114 - 152.

${ }^{26}$ Loc. cit.

${ }^{27}$ Desenvolvimento Sustentável, Estudo de Impacto Ambiental e Estudo de Impacto de Vizinhança. Curitiba: Letra da Lei, 2008. p. 58 - 59.

${ }^{28}$ Instituição do bem ambiental no Brasil, pela Constituição Federal de 1988. Seus reflexos jurídicos ante os bens da União. São Paulo: Editora Juarez de Oliveira, 2003. p. 111

${ }^{29}$ Op. cit. p. 44
} 
particular em razão do conceito de meio ambiente na Constituição Federal confirmar o fato que tal bem não pode "ser incluído dentre aqueles pertencentes a uma ou outra pessoa jurídica de direito público", pois "o meio ambiente é integrado por bens pertencentes a diversas pessoas jurídicas, naturais ou não, públicas ou privadas" e que, por outro lado, demonstraria um rompimento com "o tradicional enfoque de que os bens de uso comum só podem ser públicos".

Luís Paulo Sirvinskas ${ }^{30}$ afirma categoricamente que o bem ambiental "não pode ser classificado como bem público nem como bem privado" se situando "numa faixa intermediária entre o público e o privado, denominando-se bem difuso". Para ele, o bem ambiental "pertence a cada um e, ao mesmo tempo, a todos", seu titular não é identificável e é indivisível.

Os entendimentos retro perfilados no sentido que o bem ambiental possui natureza jurídica diferenciada do bem público são baseados, em síntese, nas seguintes idéias:

a) sobre o bem público o Estado exerce direito de propriedade, enquanto sobre o bem ambiental pode exercer somente gestão;

b) a classificação dicotômica bem público e bem privado baseia-se nas diferenças de regime de propriedade e, na medida em que o Estado não exerce tal direito sobre o bem ambiental, este não se amoldaria a uma das categorias de tal classificação;

c) por tudo isso, o bem ambiental deve ser denominado "bem difuso".

\subsubsection{Bem ambiental com natureza jurídica de bem público.}

Outro grupo de doutrinadores defende que o meio ambiente ecologicamente equilibrado ou, genericamente, bem ambiental, é bem público, porém de uma categoria diferenciada sobre a qual o Estado não exerce direito de propriedade.

As razões são aquelas mesmas que a outra corrente doutrinária se utiliza para defender uma natureza jurídica e denominação próprias para o bem ambiental: tal bem não pode ser apropriado por ninguém, é bem incluído entre os interesses difusos etc.

Interessante notar, porém, que nesta segunda corrente doutrinária também se admite que a expressão "bem de uso comum do povo", existente no texto constitucional e referente ao bem ambiental, não deve ser tomada como mera espécie de bem público,

\footnotetext{
${ }^{30}$ Manual de Direito Ambiental. São Paulo: Saraiva, 2008. p. 49
} 
tendo sido utilizada pelo legislador constituinte em sentido genérico, atécnico, comum, ou seja, simplesmente para expressar a idéia de que o meio ambiente ecologicamente equilibrado é um bem de todos, inclusive de futuras gerações, inapropriável por qualquer pessoa, pública ou privada, individualmente.

José Afonso da Silva ${ }^{31}$, por exemplo, explica que a expressão "bem de uso comum do povo" refere-se ao atributo de equilíbrio ecológico que deve possuir o meio ambiente, atributo este que "não pode ser de apropriação privada mesmo quando seus elementos constitutivos pertençam a particulares".

A qualidade de equilibro ecológico do meio ambiente é que não integra a disponibilidade de qualquer pessoa pública ou privada.

Entende, também, que alguns elementos físicos do meio ambiente, tais como água, ar, "são, já por si, bens de uso comum do povo. Por isso, como qualidade ambiental, não são bens públicos nem particulares" (grifo nosso).

E conclui que são "bens de interesse público, dotados de um regime jurídico especial, enquanto essenciais à sadia qualidade de vida e vinculados, assim, a um fim de interesse coletivo" (itálico do original).

Assim, José Afonso da Silva ${ }^{32}$ utiliza a mesma expressão "bem de uso comum do povo" para referir-se a duas idéias distintas.

A primeira idéia, sem dúvida inovadora, seria que tal expressão se refere à qualidade do meio ambiente descrito na Constituição Federal, de dever ser ecologicamente equilibrado.

A segunda idéia, esta mais tradicional, de que a expressão refere-se a “elementos físicos do meio ambiente" que são inapropriáveis, como a água e o ar.

E conclui por meio de uma junção do objeto da segunda idéia ("elementos físicos”) ao objeto da primeira idéia (o equilíbrio ecológico referente ao meio ambiente), o que caracterizaria uma categoria nova de "bens de interesse público", bens estes submetidos a um regime jurídico especial.

Portanto, o doutrinador não propõe um rompimento com a classificação dicotômica tradicional, tal como fazem aqueles da corrente doutrinária anteriormente exposta, apenas adotou uma denominação própria para o bem ambiental e o manteve na categoria de bem público.

\footnotetext{
${ }^{31}$ Op. cit. p. $80-81$
}

${ }^{32}$ Loc. cit. 
Maria Sylvia Zanella Di Pietro ${ }^{33}$ explica que a expressão "bem de uso comum do povo", aplicável ao meio ambiente ecologicamente equilibrado pela Constituição, não deve ser confundida com uma das categorias de bens públicos, neste caso coisas corpóreas, pois, o meio ambiente ecologicamente equilibrado é coisa incorpórea cuja proteção ultrapassa a esfera dos direitos individuais.

Em razão disto, tal como José Afonso da Silva ${ }^{34}$ posteriormente definiu, o meio ambiente ecologicamente equilibrado possui natureza jurídica diferenciada da classificação dicotômica de bem público e bem privado, constituindo-se como bem de interesse público.

Ou seja, a expressão do texto constitucional deve ser interpretada de forma comum, para expressar apenas a idéia de que o bem ambiental é de todos, sendo que a legislação é profícua em outros exemplos do uso de expressões neste jaez.

Confirma tal fato a anotação que Maria Sylvia Zanella Di Pietro ${ }^{35}$ faz em relação à Lei no 6.938, de 31 de agosto de 1981, que, antes da Constituição Federal de 05 de outubro de 1988, em seu artigo $2^{\circ}$, inciso I, previu que o meio ambiente, objeto de "ação governamental" para manter seu equilíbrio ecológico, é "como um patrimônio público a ser necessariamente assegurado e protegido, tendo em vista o uso coletivo" (grifo nosso).

De forma semelhante, a definição constante no texto da Lei da Política Nacional do Meio Ambiente, para o meio ambiente como "patrimônio público", também não visa inclúílo no conjunto de bens corpóreos e mesmo incorpóreos das pessoas jurídicas de direito público, mas, tão somente, confirmar o seu caráter de algo que é de todos, que é inapropriável e, por isso, é de ninguém em específico, em particular.

Tanto a expressão "bem de uso comum", constante no texto constitucional, quanto "patrimônio público", constante no texto legal anterior à Constituição Federal, foram utilizadas no sentido lato, não técnico, para exprimir o caráter de uso geral do bem jurídico ambiental.

Anotou, porém, Maria Sylvia Zanella Di Pietro ${ }^{36}$ que a linguagem utilizada pelo legislador constituinte de 1988 foi emprestada do Código Civil, porém, não exatamente no sentido de conferir ao meio ambiente ecologicamente equilibrado uma natureza de relação de propriedade com o poder público, mas, somente, para confirmar a característica de ser usufruído por todas as pessoas indistintamente:

\footnotetext{
${ }^{33}$ Polícia do meio ambiente, Revista Forense, vol. 317, Rio de Janeiro: Forense, 1992. p. 179-187

${ }^{34}$ Loc. cit.

${ }^{35}$ Op. Cit.

${ }^{36}$ Op. cit.
} 
Ao definir o direito ao meio ambiente ecologicamente equilibrado como "bem de uso comum do povo", o constituinte usou de linguagem emprestada ao Código Civil Brasileiro que, no art. 66, ao classificar os bens públicos, fala em bens "de uso comum do povo, tais como os mares, rios, estradas, ruas e praças". Doutrinariamente, bem de uso comum do povo é aquele que está aberto ao uso de todos, indistintamente; daí alguns preferirem falar em bem do domínio público e até negarem que estejam eles em relação de propriedade com o Poder Público. Embora essa tese esteja superada, ela dá bem o sentido que interessa a este tema do meio ambiente: trata-se de direito de que todos devem usufruir como condição essencial para melhoria da qualidade de vida; não é um patrimônio do Estado, mas um patrimônio público, no sentido que pertence a todos.

A mesma doutrinadora ${ }^{37}$, de forma percuciente, defende que a expressão "bem de uso comum do povo" pode ser aplicada para coisas corpóreas, aí sim espécie de bens públicos, como pode ser aplicada ao meio ambiente ecologicamente equilibrado, aí coisa incorpórea, mas ambos os casos "trata-se de coisas insuscetíveis de avaliação patrimonial; em e outro caso, trata-se de coisas cuja proteção ultrapassa a esfera dos direitos individuais para entrar na categoria dos interesses públicos”.

Interessante notar, ainda, que no artigo $225, \S 4^{\circ}$, da Constituição Federal também é previsto que a Floresta Amazônica brasileira, a Mata Atlântica, a Serra do Mar, o Pantanal Mato-Grossense e a Zona Costeira são "patrimônio nacional", cuja utilização deve assegurar, na forma da lei, a preservação do meio ambiente inclusive quanto ao uso dos recursos naturais.

Nesse dispositivo constitucional encontra-se mais um exemplo do uso da linguagem não técnica para expressar uma idéia de que tais ecossistemas merecem proteção especial, ainda que os particulares exerçam o direito de propriedade sobre bens imóveis situados nas áreas componentes de tais ecossistemas.

Ou seja, conforme ressaltado por Maria Sylvia Zanella Di Pietro ${ }^{38}$, “o dispositivo nada mais é do que um prolongamento ou uma aplicação da idéia maior, contida no caput do art. 225, de colocar como bem de uso comum do povo o direito ao meio ambiente ecologicamente equilibrado".

A doutrinadora ressaltou que, também no Código Florestal, Lei ${ }^{\circ} 4.771$, de 15 de setembro de 1965, no seu artigo $1^{\circ}$, se previu que as florestas e demais formas de

\footnotetext{
${ }^{37}$ Loc. cit.
}

${ }^{38}$ Loc. cit. 
vegetação existentes no território nacional são "bens de interesse comum a todos os habitantes do país, exercendo-se os direitos de propriedade com as limitações que a legislação em geral e especialmente esta Lei estabelecerem".

Colocado desta forma, não é difícil concluir que as expressões "bens de interesse comum a todos", "patrimônio público", "bem de uso comum do povo" e "patrimônio nacional", que nos textos normativos referem-se ao bem ambiental, devem ser interpretadas apenas como declarações do caráter de generalidade do uso de tal bem pelas pessoas, com a impossibilidade de apropriação do mesmo por alguém em particular, até mesmo pela natureza incorpórea do mesmo, daí sua natureza de interesse difuso.

Floriano Peixoto de Azevedo Marques Neto $^{39}$ resume que os bens públicos podem ser divididos em bens de propriedade do Estado e bens de "propriedade comum", "pertença de todos apenas gerida pelo Estado", cujo uso é exercido por todos, dividindo-os em "público-Estatal (ou seja, aquilo que se refere à pessoa jurídica de direito público Estado, titular de direitos de propriedade sobre bens) e o público-comum (atinente aos bens que pela sua natureza não são apropriáveis por qualquer pessoa, que pertencem a todos em comum e são apenas atribuídas ao Estado como decorrência do domínio eminente)".

$\mathrm{Na}$ explicação do doutrinador ${ }^{40}$ há menção a doutrina tradicional do domínio eminente, como causa da atribuição do "bem público-comum" ao Estado, que, por sua vez, assim pode ser definido:

O domínio eminente se traduz num domínio abstrato do Estado sobre todas as coisas contidas no território. Ele decorre diretamente da soberania, do poder do Estado de concentrar a autoridade, da prerrogativa que o poder público possui sobre pessoas e coisas dentro do seu território. Do domínio eminente decorre não a propriedade sobre todas as coisas contidas no território, mas a prerrogativa de ordenar e disciplinar o exercício desta propriedade (poder-dever de vigilância, proteção e de polícia, nas palavras de Rodrigo OTÁVIO).

Além disso, para o doutrinador, no contexto hodierno a função sócioambiental da propriedade desempenha importante vetor na manifestação do domínio eminente do Estado sobre todos os bens do território nacional.

\footnotetext{
${ }^{39}$ O Regime Jurídico das utilidades públicas: função social e exploração econômica dos bens públicos. São Paulo, 2008, Tese de livre docência, Data de defesa 02.10.2008, Faculdade de Direito da Universidade de São Paulo, p. 31

${ }^{40}$ Op. cit., p. 86
} 
Independentemente da causa, a nota comum nos três entendimentos doutrinários é a manutenção do bem cuja propriedade não é de uma pessoa em específico na categoria de bem público.

A categoria de bem público é, portanto, alargada e se compõe também por aquele bem que é de todos, inapropriável por uma pessoa em específico, modificando-se apenas o papel desempenhado pelo Estado perante eles, não de propriedade, mas de mera gestão.

Esta forma de compreender o bem público não foi considerada pelos doutrinadores jus-ambientalistas que afirmam ser insuficiente o direito administrativo para explicar a natureza jurídica própria do bem ambiental.

\subsubsection{Natureza jurídica do bem ambiental.}

De todos os entendimentos perfilados é possível retirar algumas conclusões, sendo, de partida, a mais importante a noção que a expressão "bem de uso comum do povo", constante no "caput", do artigo 225, da Constituição Federal, adjetiva do meio ambiente ecologicamente equilibrado, não possui o sentido restrito de uma das espécies de bem público.

Tendo sido tal expressão utilizada ou não em linguagem comum, no sentido de referência a um bem jurídico que todos os seres humanos usufruem, nas presentes e futuras gerações, podendo até ser substituída por outras equivalentes, tais como "bem de uso comum da humanidade", "bem de uso coletivo", enfim, todas expressões da linguagem comum que designam o caráter de bem jurídico difuso, de coisa incorpórea, de bem inapropriável por determinada pessoa, seja pública ou privada, o fato é que o bem ambiental pode ser considerado um bem público.

Os raciocínios que alicerçam as conceituações construídas por doutrinadores jus-ambientalistas, que tentam demonstrar a incompatibilidade do bem ambiental à categoria de bem público e, em conseqüência, justificar a existência de uma terceira espécie "sui generis" de bem jurídico, no fundo partem da descrição dos caracteres do bem ambiental, tais como o fato de ser um interesse difuso, de ser composto por elementos incorpóreos, de ser insuscetível de compor o patrimônio de uma pessoa física ou jurídica, pública ou privada, características estas que não são suficientes para justificar a defendida natureza diversa. 
Sem dúvida, o bem ambiental possui todas essas características que, realmente, torna-o diferenciado de qualquer outra coisa corpórea ou incorpórea que possa constituir o patrimônio jurídico de um sujeito de direitos específico.

O bem ambiental é bem jurídico, ou seja, objeto de direito, de relações jurídicas não patrimoniais de todos os sujeitos de direitos, relações estas que, a falta de melhor definição, caracterizam-se como uso, fruição, de tal bem ambiental, não se confundindo com atributos da propriedade descritos na tradicional doutrina do direito civil.

Nesse contexto, o bem ambiental realmente não se amolda a qualquer regime de dominialidade, seja público ou privado, pois a relação jurídica que todo sujeito de direito estabelece com tal bem não é relação de propriedade, mas somente de uso, de fruição, de conservação, respeitando-se os limites que a lei ambiental estabelece para que não haja degradação da qualidade ambiental.

Se a classificação dicotômica de bem público e bem privado prende-se substancialmente à relação jurídica de propriedade, realmente o bem ambiental não se encaixa, em princípio, em tal classificação.

Em razão disso, também, nas definições há proposição no sentido que a função do Estado perante o meio ambiente não seria de exercício dos atributos da propriedade, mas de exercício de mera gestão, pois o Estado é gestor do meio ambiente ecologicamente equilibrado e não seu proprietário.

Mesmo que se queira negar que o bem ambiental encontra-se na categoria de bem público, é inegável que aquele possui um ponto em comum com este último, ponto este que também o diferencia bem privado: tanto o bem ambiental, quanto o bem público, são regrados por regime jurídico especial, diferenciado do regime privado.

Confirma tal assertiva a clássica doutrina de Mário Masagão ${ }^{41}$, na qual demonstra que os bens públicos são caracterizados a regime jurídico especial: "Em nossa opinião, só há dois característicos próprios dos bens públicos: a) pertencem às pessoas jurídicas de direito público interno; b) estão sujeitos a regime especial, oriundo de normas do direito público" (grifo nosso).

Ainda, mesmo dentro do regime jurídico de propriedade pública encontram-se diferentes regimes jurídicos, a depender da espécie de bem público que, por sua vez, dependem da natureza patrimonial do bem e de seu uso pela coletividade e pelo Estado.

\footnotetext{
${ }^{41}$ Curso de Direito Administrativo, São Paulo: Editora Revista dos Tribunais, 1968. p. 119
} 
Esclarece tal aspecto Maria Sylvia Zanella Di Pietro ${ }^{42}$, quando, em relação aos bens de uso comum do povo e bens de uso especial, afirma que "subordinam-se a regime jurídico próprio, informado por princípios publicísticos, derrogatórios e exorbitantes do direito comum".

Estas considerações servem para confirmar que, de certa forma, falta maior profundidade nas definições da maioria dos jus-ambientalistas suso referidos, pela completa ausência de menção ao segundo aspecto que caracteriza o regime de dominialidade pública, a pedra de toque com o regime regente do bem ambiental: a existência de regramento jurídico derrogatório do direito comum, regime jurídico este que preserva a função de tais bens.

Maria Sylvia Zanella Di Pietro ${ }^{43}$ também demonstra que o próprio conceito de domínio público é equívoco, admitindo três sentidos: amplo, menos amplo e restrito.

No sentido amplo, seriam os bens que pura e simplesmente constituem o patrimônio das pessoas jurídicas de direito público interno.

No sentido menos amplo, seriam os bens afetados a um uso público, nele se incluindo os bens de uso comum do povo e os bens de uso especial.

Finalmente, em sentido restrito, correspondente ao "demanio" do direito italiano, seriam somente os bens de uso comum do povo.

As citadas definições que propõem uma natureza jurídica diferenciada ao bem ambiental apegam-se muito mais ao mencionado sentido amplo do domínio público, ou seja, os bens que constituem o patrimônio das pessoas jurídicas de direito público interno.

Nessa discussão, ainda, relevante a lição de Edmir Netto de Araújo ${ }^{44}$, para quem “o enfoque da noção de domínio público é sua referibilidade ao Estado e à coletividade, com afetação à finalidade pública e submissão a regime jurídico de direito público", idéias estas que também são aplicáveis ao bem ambiental.

$\mathrm{Na}$ doutrina alienígena, Blanca Lozano Cutanda ${ }^{45}$ explica que os textos constitucionais de países europeus promovem uma "demanialização dos recursos naturais" quando prevêem que bens ambientais são "bienes de domínio público estatal", com atribuição deles ao Estado, sendo esta "una técnica dirigida primordialmente a excluir el

\footnotetext{
${ }^{42}$ Uso privativo de bem público por particular, São Paulo: Revista dos Tribunais, 1983. p. 05

${ }^{43}$ Direito Administrativo, São Paulo: Saraiva, 2008. p. 634

${ }^{44}$ Curso de Direito Administrativo. São Paulo: Saraiva, 2005. p. 1058

${ }^{45}$ Derecho Ambiental Administrativo, Madrid: Dykinson, 2003. p. 385
} 
bien afectado del tráfico jurídico privado, protegiéndolo de esta exclusión mediante una serie de reglas exorbitantes de las que son comunes em dicho tráfico privado".

Ou seja, denomina a citada doutrinadora de "demanialização" a criação de regramento jurídico próprio para os bens ambientais, também derrogatório do regime jurídico comum, cuja principal característica é torná-los bens de uso comum do povo, no sentido comum de tal expressão, inapropriáveis.

Nesta maneira de ver, pode-se concluir que o bem ambiental possui com o bem público a característica comum de possuir um regime jurídico derrogatório do regime jurídico de direito privado, o que também confirma sua natureza de bem público especial.

De tudo o que se expôs, conclui-se que o bem ambiental pode ser considerado um bem público, diferenciado pelo fato do poder público sobre ele não exercer direito de propriedade, por tratar-se de coisa incorpórea, imaterial, inapropriável, mas gestão.

Quanto a uma denominação específica, quer de "bem de interesse público" ou "bem público-comum", entende-se ser desnecessária, uma vez que a utilização da expressão "bem ambiental” se configura suficiente para designá-lo.

A existência de um regime jurídico próprio, derrogatório do regime de dominialidade privada, e amplificado pelo princípio da função sócio-ambiental, confirma também sua natureza de bem público.

O gênero bem público, dentro dessa visão, deve ser dividido da seguinte forma:

a) bens sobre os quais o poder público exerce direito de propriedade: bens públicos estatais, subdivididos conforme a classificação tradicional do direito civil, segundo o uso, em bens de uso comum do povo, bens de uso especial e bens dominicais; constituídos por coisas corpóreas em grande parte;

b) bens sobre os quais o poder público exerce gestão: por alguns denominados "bens públicos-comuns", para outros "bens de interesse público", aqui o bem ambiental, coisa incorpórea, inapropriável por qualquer pessoa física ou jurídica, pública ou privada.

Na citada classificação, denota-se que o critério diferenciador refere-se ao exercício ou não do direito de propriedade, pois, em ambas as categorias é preservado o critério finalístico ou funcional, ou seja, o bem público em qualquer das hipóteses é sempre voltado a um uso de interesse público, sendo no caso do bem ambiental, a sua preservação, para presente e futuras gerações. 


\subsubsection{Conclusão quanto à natureza jurídica da flora.}

Conforme analisado no item 1.2.1, a flora é um elemento que compõe o conceito de meio ambiente natural.

O meio ambiente natural, por sua vez, compõe um conceito maior de meio ambiente, juntamente com o meio ambiente artificial, cultural e do trabalho.

O meio ambiente ecologicamente equilibrado ou, simplesmente, bem ambiental, é conceituado na Constituição Federal como "bem de uso comum do povo", expressão esta que deve ser interpretada como confirmação do fato daquele tratar-se de um bem cujo uso todos podem exercer, sendo inapropriável por qualquer pessoa física ou jurídica, pública ou privada, por isso, é um bem sobre o qual o Estado exerce apenas gestão e não direito de propriedade, como ocorre em relação às demais espécies de bens públicos.

Ademais, o bem ambiental também possui um regime jurídico próprio, derrogatório do regime jurídico de dominialidade privada, que confirma sua natureza de bem público e possui como nota marcante a função sócio-ambiental da propriedade.

Estando a flora inserta no conceito de bem ambiental, trata-se também de bem público sobre o qual o Estado deve exercer a gestão, conforme prevê o "caput", do artigo 225, da Constituição Federal, com a finalidade pública de sua preservação para as presentes e futuras gerações.

Em relação às florestas em si, assim como ocorre com outros elementos do bem ambiental, os regimes de dominialidade e gestão ao qual estão inseridas serão abordados oportunamente adiante.

\subsection{Evolução histórica da tutela legal do patrimônio florestal.}

Desde os primórdios da história moderna, na Europa existe a preocupação com a proteção legal do patrimônio florestal, principalmente contra incêndios e para a preservação da função florestal de formação dos mananciais.

Por exemplo, segundo Nara Cristina Esteves Fonseca Gonçalez ${ }^{46}$, na França, a administração das florestas é até os dias hodiernos denominada "administração de águas e florestas", em razão da expressão cunhada em 1.291, pelo Rei Felipe, "le Bel”,

\footnotetext{
${ }^{46}$ Contribuição da legislação florestal francesa para a legislação brasileira, Brasília ano 43, n 169, jan./mar. 2006, p. 265-276
} 
ao estabelecer as regras que delimitavam a competência dos "mestres das Águas e das Florestas".

Ainda em tal país, consta que no período feudal as florestas pertenciam ao rei, aos senhores feudais e às comunidades religiosas, podendo, porém, ser concedidas por meio de "cartas de franquia" aos particulares.

Em Portugal, encontram-se regras de proteção ambiental, especialmente proibição de corte deliberado de árvores, nas Ordenações Afonsinas, editadas pelo Rei Dom Afonso IV e em vigor a partir de 12 de março de 1.393.

Entretanto, a Carta Régia de 27 de abril de 1.442 é reconhecida como o primeiro instrumento legal de Portugal de proteção específica da flora, porém em razão especificamente dos incêndios que assolavam as florestas portuguesas.

Apesar da existência de tais leis, as mesmas não foram suficientes para impedir a devastação das florestas pelos colonizadores portugueses em várias áreas conquistadas, sendo um emblemático exemplo de tal fato o relatado por Américo Luís Martins da Silva ${ }^{47}$, em relação a exploração da Ilha da Madeira:

Após descobrir a Ilha da Madeira e logo que ela começou a dar lucros, através da exploração de madeira, da resina de uma árvore chamada "sangue de dragão", que tingia tecidos, e da produção de trigo, João Gonçalves Zarco, para chegar ao centro da ilha, colocou fogo nas florestas, que queimaram durante 7 (sete) anos sem parar.

No Brasil, segundo Antônio Hermann de Vasconcelos e Benjamin ${ }^{48}$, desde o descobrimento em 1.500 até quase o início da segunda metade do século XX, "pouca atenção recebeu a proteção ambiental no Brasil, à exceção de umas poucas normas isoladas que não visavam, na vocação principal, resguardar o meio ambiente como tal", mas apenas "assegurar a sobrevivência de alguns recursos naturais preciosos em acelerado processo de exaurimento (o pau-brasil, p.ex.)".

Neste contexto do Brasil colonial, a Coroa Portuguesa, pela Lei de 1.605, criou as "reservas extrativistas" de pau-brasil, sob controle da realeza, e a função de

\footnotetext{
${ }^{47}$ Direito do meio ambiente e dos recursos naturais, São Paulo: Editora Revista dos Tribunais, 2005, p. 81

${ }^{48}$ Introdução ao Direito Ambiental Brasileiro, in Anais do $3^{\circ}$ Congresso Internacional de Direito Ambiental, 30 de maio a 02 de junho de 1999: a proteção jurídica das florestas tropicais, organizado por Antônio Hermann de Vasconcelos e Benjamin, São Paulo: IMESP, 1999, p. 77
} 
"guardas florestais" para fiscalizar a exploração de tal espécie. Em relação a tal lei, Gilberto D'Ávila Rufino ${ }^{49}$ detalha:

A Ordem Régia de 12 de dezembro de 1.605 impunha a pena de morte para aqueles que transgredissem as normas sobre a exploração das florestas litorâneas. Mais tarde essas disposições foram reforçadas por um regulamento detalhado da exploração florestal (Ordem Régia de 1.797).

Andréa Struchel e Elson Rony Servilha ${ }^{50}$ consideram tal lei a primeira "protecionista" florestal brasileira, "inclusive com previsão de pena de morte para o corte do pau-brasil sem expressa licença real ou do provedor-mor" não havendo notícia de qualquer execução para tal fim.

Em 1.635 veio a lume o Regimento do Pau-Brasil, pelo qual foram instituídas as "conservatórias", áreas que visavam certa conservação e racionalização no uso dos recursos naturais e, principalmente, em relação ao corte de tais árvores, sujeitavam-no a autorização das autoridades públicas da época.

As Ordenações Filipinas também dispuseram sobre o controle de corte de árvores, utilização, proibição do corte de determinadas espécies e proibição de queimadas, com penalidades de pagamento de indenização, açoite e degredo para a África ou Brasil, por até quatro anos quando houvesse grandes danos.

Pela Carta Régia de 13 de março de 1.797, a Coroa previu ser de propriedade real "todas as matas e árvores à borda da Costa, ou de rios que desemboquem imediatamente no mar, e por onde em jangadas se possam conduzir as madeiras cortadas até o mar".

O Regimento de 11 de julho de 1.799, dispôs sobre o corte de madeira no Brasil e criou o "juiz conservador", cuja competência relacionava-se com a fiscalização da atividade madeireira.

Entretanto, tendo tal decreto vigorado por apenas três anos, em razão das pressões dos colonos, em 01 de julho de 1.802 foram editadas novas normas sobre reflorestamento.

\footnotetext{
${ }^{49}$ Direito Florestal da Amazônia (uma análise do regime florestal e suas implicações fundiárias), in Anais do $3^{\circ}$ Congresso Internacional de Direito Ambiental, 30 de maio a 02 de junho de 1999: a proteção jurídica das florestas tropicais, organizado por Antônio Hermann de Vasconcelos e Benjamin, São Paulo: IMESP, 1999, p. 148

${ }_{50}$ O Direito, as Leis e a Conservação da Floresta, in Revista de Direito Ambiental, ano 12, n. 46, abr.jun./2007, p. 17-40
} 
Do relato breve de todas essas normas, chega-se à conclusão que, no período inicial da colonização, tais normas visavam muito mais a proteção de interesses econômicos do que uma preocupação de conservação ambiental, fato este também realçado por Teresa Cristina de Deus ${ }^{51}$,

Certamente a motivação de nossos colonizadores, ao disporem sobre corte de árvores, era bastante diferente das atuais noções de proteção ecológica. Naquele tempo, ao impedir o corte de um determinado tipo de árvore o que se pretendia era manter, ou melhor dizendo, economizar bens de valor econômico alto para fins de fabrico de móveis, essências ou tintas. (negrito do original)

Com isso, adentra-se no período imperial, onde a Constituição de 25 de março de 1.824 sequer dispunha sobre proteção da flora.

Esta realidade é modificada somente pelo Regimento de 15 de outubro de 1.827, que incumbia aos juízes de paz das províncias fiscalizar as matas e cuidar da interdição do corte das madeiras de construção em geral, denominadas, por isso, até os dias atuais de "madeiras de lei", o que também é confirmado pela notícia histórica anotada por Gilberto D’Ávila Rufino ${ }^{52}$ :

Após a Independência, manteve-se a proibição do 'corte de pau-brasil, perobas e tapinhoãs aos particulares'. A proibição de roçar e derrubar matas em terras devolutas foi reafirmada em 1.829, quando a competência para outorgar as licenças passou às câmaras municipais. A Lei de 15 de outubro de 1.827 originou a expressão até hoje usada de "madeira de lei".

Conforme o trecho doutrinário supra transcrito, a Lei de 11 de junho de 1.829 incumbiu às Câmaras de Vereadores das províncias a competência de autorizar o corte de árvores nas terras devolutas, sob pena de ser considerada ilegal tal prática, caso ausente essa autorização.

No Código Penal de 1.830, em seus artigos 178 e 257, o corte ilegal de madeiras foi tipificado como crime.

Não se pode olvidar que a Lei $\mathrm{n}^{\circ} 601$, de 18 de setembro de 1.850, denominada de "Lei de Terras", também objetivou conter a destruição ambiental em terras públicas, além de prever que as mesmas poderiam ser adquiridas somente por compra e venda, proibir a usucapião de tais terras e declarar crime a sua posse desautorizada.

${ }^{51}$ Tutela da flora em face do direito ambiental brasileiro, São Paulo: Juarez de Oliveira, 2003. p. 94
${ }^{52}$ Op. cit., p. 148 
No período republicano, a Constituição de 1.891 também não definiu qualquer competência para legislar sobre florestas, o que é explicado por José Afonso da Silva $^{53}$ como conseqüência da concepção privatista do direito de propriedade adotada à época:

A concepção do direito de propriedade adotada na Constituição de 1.891, no entanto, impediu prosperasse uma política protetora eficaz das florestas e demais formas de vegetação porque nela se consubstanciava a idéia individualista segundo a qual o proprietário poderia usar, gozar e dispor de sua propriedade como melhor lhe aprouvesse. Em consequiência, custou muito a aparecer uma ordenação jurídica sistematizada de proteção florestal.

Apesar do silêncio legislativo no nível federal até a Revolução de 1.930, registra José Afonso da Silva ${ }^{54}$ que muitos estados da federação criaram seus próprios serviços florestais, tal como a Bahia, em 1905, ou editaram seus próprios códigos florestais, como o Paraná, em 1.907.

Somente pelo Decreto no 23.793, de 23 de janeiro de 1.934, foi instituído o primeiro Código Florestal que não foi suficientemente eficaz para evitar a degradação das florestas brasileiras.

Andréa Struchel e Elson Roney Servilha ${ }^{55}$ lecionam que, apesar da edição do referido código não ter cessado a devastação em curso, "pela primeira vez, reconheceu a floresta como um bem de interesse comum, não só dos brasileiros natos, mas de todos os habitantes do país.", daí sua importância como marco inicial como idéia de bem ambiental de todas as pessoas, incorporada ao direito ambiental brasileiro posterior.

Neste antigo código foi estabelecida uma classificação para as florestas em protetoras, remanescentes, modelo e de rendimento.

As florestas protetoras foram definidas como aquela que, por sua localização, servem a fins determinados, tais como de proteção de mananciais, evitar a erosão do solo por agentes naturais, fixar dunas, auxiliar na defesa de fronteiras, assegurar condições de salubridade pública, abrigar exemplares raros de fauna.

As florestas declaradas remanescentes eram as que formavam os parques nacionais, estaduais e municipais, bosques e pequenos parques públicos entre outras.

\footnotetext{
${ }^{53}$ Direito Ambiental Constitucional, São Paulo: Malheiros, 2000. p. 159

${ }^{54}$ Loc. cit.

${ }^{55}$ Op. cit., p. 22
} 
As florestas modelo eram definidas como artificiais e constituídas por determinados indivíduos florestais, exóticos ou indígenas, cuja disseminação fosse importante para determinada região.

O conceito das florestas de rendimento era residual, sendo constituídas por aquelas que não se amoldassem às categorias anteriores.

Gilberto D’Ávila Rufino ${ }^{56}$ esclarece que o Código Florestal de 1934 tentou modificar o conceito de propriedade quando nela houvesse florestas cuja "existência fosse devida às próprias forças da natureza" e declarou as matas existentes no território nacional "bem de interesse comum do povo a todos os habitantes do país", porém, tais dispositivos não tiveram maior alcance prático.

Tal código não foi capaz de garantir a preservação de porções nos imóveis para "perenidade da quarta parte das florestas", sendo que tal dispositivo, segundo o mesmo doutrinador, "foi na prática deturpado por diferentes e capciosos argumentos, entre os quais o artifício de aplicar-se a regra da proporcionalidade sobre toda a área do imóvel e não apenas em relação à mata existente".

E nele se permitiu também a derrubada da floresta heterogênea para substituição pela floresta homogênea, "para maior facilidade de sua exploração industrial", concepção esta ultrapassada e que possibilitou a destruição de importantes biomas.

Segundo Moisés Villalba González e Carlos José Caetano Bacha ${ }^{57}$, no Código Florestal de 1934 foi restringido o desmatamento nas propriedades privadas em "até $75 \%$ da vegetação existente e instituiu a obrigatoriedade de o proprietário rural obter licenças para explorar áreas próximas aos rios e lagos. Também previa a criação de unidades de conservação.". Porém, segundo eles, os resultados dessas medidas "foram pífios e o processo de desmatamento foi intensificado após 1934.”.

Também, conforme adiante se esclarecerá melhor, o antigo Código Florestal de 1934 dispôs sobre a exploração de florestas públicas, o que não foi inserido no Código Florestal que o sucedeu.

Coube à Constituição de 16 de julho de 1.934 , em seu artigo $5^{\circ}$, n. XIX, letra $\mathrm{j}$, a primeira atribuição de competência legislativa, em nível constitucional, sobre florestas e sua exploração à União, informação confirmada por José Afonso da Silva ${ }^{58}$.

\footnotetext{
${ }^{56}$ Op. cit., p. 149

${ }^{57}$ As Políticas Florestais do Brasil e Paraguai, in Teoria e Evidência Econômica, Passo Fundo, v. 14, n. 28, p. 37-56, maio 2007

${ }^{58}$ Op. cit., p. 160
} 
Na Constituição de 10 de novembro de 1.937 , foi prevista a competência legislativa e material de exploração da floresta, tanto para a União, quanto para os Estadosmembros.

Pelo Decreto-lei $\mathrm{n}^{\mathrm{o}} 1.202$, de 8 de abril de 1.939, foi previsto que a vigência de decretos-leis que dispusessem sobre arrendamento, concessão ou autorização de exploração de florestas, regime, regulamentação, bem como sobre riquezas florestais e sua exploração deveria ser condicionada à aprovação do Presidente da República.

O Serviço Florestal Brasileiro, entidade responsável pela gestão das florestas, foi criado pelo Decreto-lei no 4.439, de 26 de julho de 1.939.

Ainda no governo de Getulio Vargas, pelo Decreto-Lei n ${ }^{\circ} 2.014$, de 13 de fevereiro de 1940, foram os Estados autorizados a promover a guarda e fiscalização das florestas existentes em seus territórios.

No artigo 250, do Decreto-lei $\mathrm{n}^{\mathrm{o}} 2.848$, de 07 de dezembro de 1.940, Código Penal, foi previsto o aumento de pena no crime de incêndio em mata ou floresta.

No Decreto-lei $n^{\circ} 3.583$, de 03 de setembro de 1.941, foi proibida a derrubada de cajueiros em áreas rurais do território nacional, conforme entendimento da época em razão da importância florestal de tal espécie vegetal, além de ser fonte de matéria prima para indústrias nacionais e exportação, motivos pelos quais se pretendia um estímulo à sua cultura organizada.

Pelo Decreto-lei no 3.914, de 09 de dezembro de 1.941, Lei de Introdução ao Código Penal e à Lei de Contravenções Penais, foram transformadas em contravenções penais os fatos tipificados como crimes nos artigos $3^{\circ}$ e $4^{\circ}$ do Código Florestal.

No artigo $5^{\circ}$, inciso $\mathrm{XV}$, item 1 , da Constituição de 18 de setembro de 1.946, foi estabelecida a competência da União para legislar sobre floresta e, no artigo 175, foi determinada a proteção pelo poder público dos monumentos naturais, paisagens e os locais dotados de particular beleza, portanto, tal texto constitucional avançou um pouco mais na tutela ambiental em geral.

Pela Lei $\mathrm{n}^{\mathrm{o}} 4.466$, de 12 de novembro de 1.964, o governo federal determinou a arborização das margens das rodovias do Nordeste e, pelo Decreto $\mathrm{n}^{\circ} 55.795$, de 24 de fevereiro de 1.965, instituiu a Festa Anual das Árvores em todo o território nacional, cujo objetivo, à época alegado, era o de difusão de conhecimentos sobre a conservação da floresta e conscientização da importância ambiental das árvores no progresso da Pátria e bem estar dos cidadãos. 
A Lei $\mathrm{n}^{\circ}$ 5.106, de 02 de setembro de 1966, dispôs sobre a concessão de incentivos fiscais às pessoas físicas e jurídicas que empreendessem florestamento e reflorestamento.

$\mathrm{Na}$ Constituição de 24 de janeiro de 1.967 , em seu artigo $8^{\circ}$, inciso XV, item $\mathrm{h}$, foi disciplinada a competência da União para legislar sobre florestas e, no seu artigo 172, foi previsto o dever de proteção, pelo poder público, dos monumentos e paisagens naturais notáveis.

Apesar dos inúmeros diplomas legais, disciplinando diferentes aspectos relativos às florestas, pode-se concluir que a devastação florestal caminhava, desde aquela época, a passos largos no território brasileiro.

\subsection{Bloco normativo de tutela do patrimônio florestal.}

A Constituição Federal de 05 de outubro de 1988, sem dúvida, constituise no diploma legal de maior detalhamento da tutela do patrimônio florestal brasileiro.

Nos artigos 23, inciso VII e 24, inciso VI, da Constituição Federal de 1988, são previstas as competências material e legislativa em matéria florestal, objeto de análise mais aprofundada adiante.

No artigo $225, \S \S 1^{\circ}$ e $4^{\circ}$, da Constituição Federal de 1988, encontra-se a regra de que a proteção da flora é incumbência do poder público e as florestas que compõem determinados ecossistemas considerados "patrimônio nacional", expressão esta designativa de sua maior importância para o povo brasileiro e não propriamente a sua inclusão no acervo patrimonial do poder público federal.

Quanto às normas infraconstitucionais, o diploma legal base é a Lei $n^{\circ}$ 4.771, de 15 de setembro de 1.965, atual Código Florestal, que possui regras jurídicas de maior abrangência se comparadas com as do antigo Código Florestal de 1934.

O atual Código Florestal também sofreu diversas alterações, principalmente na década de oitenta do século passado e primeira década do presente, sendo relevante citar que as alterações mais profundas foram implementadas pela Lei $\mathrm{n}^{\mathbf{o}}$ 7.511, de 07 de julho de 1986, revogada pela Lei $\mathrm{n}^{\circ}$ 7.803, de 18 de julho de 1989 e pela Medida Provisória $n^{\circ}$ 2.080-58, de 27 de dezembro de 2000, revogada pela Medida Provisória nº 2.166-67, de 24 de agosto de 2001.

A Lei do Sistema Nacional das Unidades de Conservação - SNUC (Lei no 9.985, de 18 de julho de 2000), a Lei de Gestão das Florestas Públicas (Lei nº 11.284, de 
02 de março de 2006) e a Lei de Proteção do Bioma Mata Atlântica (Lei nº 11.428, de 22 de dezembro de 2006), também introduziram importantes alterações no atual Código Florestal.

Um exemplo que comprova a maior abrangência do atual Código Florestal, em comparação com a disciplina do antigo, é a ampliação do conceito de bem jurídico objeto de sua proteção, incluindo-se não só as florestas como também "as demais formas de vegetação" e "terras que revestem", conforme dispõe seu artigo $1^{\circ}$, entendimento este coincidente com o de Paulo de Bessa Antunes ${ }^{59}$.

Na mesma direção Américo Luís Martins da Silva ${ }^{60}$, que assim anota:

Há que se destacar que a abrangência do atual Código é maior que a do anterior (não só as florestas foram elevadas à categoria de bem público ou privado de interesse comum) haja vista alcançar ele não apenas a proteção das florestas propriamente ditas, mas, também, a das "demais formas de vegetação natural", reconhecidas de utilidade para as terras que revestem e quando declaradas por ato do Poder Público de preservação permanente.

O atual Código Florestal também dispõe sobre as florestas e demais formas de vegetação de preservação permanente, que assim podem ser divididas:

a) as do seu artigo $2^{\circ}$, em razão da localização e função ambiental, como, por exemplo, aquelas situadas ao longo dos rios ou de outro curso d’água; ao redor de lagoas, lagos ou reservatórios artificiais ou naturais; nas nascentes e olhos d’água; no topo de morros, montes, montanhas e serras; nas encostas ou partes destas, cuja declividade seja superior a $45^{\circ}$ (quarenta e cinco graus); nas restingas, como fixadoras de dunas ou estabilizadoras de mangues; nas bordas de tabuleiros ou chapadas; em altitude superior a 1.800 (mil e oitocentos) metros qualquer que seja a vegetação;

b) as do seu artigo $3^{\circ}$, "quando assim declaradas por ato do Poder Público", também em razão da função ambiental prevista no Código, tais como para atenuar a erosão de terras; fixar as dunas; formar faixas de proteção ao longo de rodovias ou ferrovias; auxiliar na defesa do território nacional; proteger sítios de excepcional beleza ou de valor científico ou histórico; asilar exemplares da fauna ou flora ameaçados de extinção; manter o ambiente necessário à vida das populações silvícolas e assegurar as condições de bem-estar público.

Os dois dispositivos legais retro citados estão abarcados no conceito mais amplo de "áreas de preservação permanente", expressão esta introduzida no inciso II, do

\footnotetext{
${ }^{59}$ Direito ambiental, Rio de Janeiro: Editora Lumen Juris, 1999. p. 240

${ }^{60}$ Op. cit., p. 84
} 
artigo $1^{\circ}$, do atual Código Florestal, pela Medida Provisória ${ }^{\circ} 2.166$, de 24 de agosto de 2001, cuja importância assim é melhor explicada por Paulo Affonso Leme Machado ${ }^{61}$ : "pois é um espaço territorial em que a floresta ou a vegetação devem estar presentes. Se a floresta aí não estiver, ela deve ser aí plantada.".

Ainda, tal doutrinador professa que a idéia de permanência não deve estar vinculada somente às florestas, mas também ao solo e à fauna e "se a floresta perecer ou for retirada, nem por isso a área perderá sua normal vocação florestal.”.

De fundamental importância também é a disciplina que o atual Código Florestal faz em relação ao regime de restrição da utilização das florestas do domínio privado, em seus artigos 16 e 44, onde, além das áreas de preservação permanente, se impõe o respeito a percentuais da propriedade privada, nos quais se localizam vegetação, que devem ser mantidos inexplorados, sendo denominados de "reserva legal florestal". Tais percentuais, por sua vez, variam a depender da região do país, conforme adiante melhor se explica.

Inovou o Código Florestal de 1965 ao prever, em seu artigo 18, a possibilidade do Poder Público Federal promover florestamento ou reflorestamento de preservação permanente em terras de propriedade privada cujos proprietários assim não o fizer, sem, no entanto, desapropriá-las.

Além de o atual Código Florestal ter sido modificado pela Lei $n^{\circ} 7.803$, de 15 de agosto de 1989 e pela Medida Provisória no 2.166-67, de 24 de agosto de 2001, há farta regulamentação por atos administrativos normativos, tais como a Resolução CONAMA n 302, de 20 de março de 2002, que dispõe sobre parâmetros, definições e limites de áreas de preservação permanente de reservatórios artificiais e o regime de uso do entorno e a Resolução CONAMA no 303, da mesma data, que dispõe igualmente sobre parâmetros, definições e limites de áreas de preservação permanente, de forma mais genérica.

O artigo 19, do Código Florestal, que disciplina a exploração de florestas e de formações sucessoras, tanto de domínio público como de domínio privado, é regulamentado pelo Decreto $\mathrm{n}^{\mathrm{o}} 5.975$, de 30 de novembro de 2006, entre outros atos normativos.

Deve-se notar que assuntos específicos, tais como a reposição florestal, floresta plantada, gestão florestal, desmatamento, recebem farto tratamento em atos

${ }^{61}$ Op. cit., p. 735 
administrativos do Instituto Brasileiro do Meio Ambiente e Recursos Naturais Renováveis - IBAMA, autarquia federal supervisionada pelo Ministério do Meio Ambiente criada pela Lei Federal no 7.735, de 22 de fevereiro de 1989.

A flora também é tutelada, de forma mais ampla, pela Lei $n^{\circ} 6.938$, de 31 de agosto de 1.981, denominada Lei da Política Nacional do Meio Ambiente, alterada pela Lei $\mathrm{n}^{\mathrm{o}} 7.804$, de 18 de julho de 1989, juntamente com a Lei $\mathrm{n}^{\circ}$ 9.605, de 12 de fevereiro de 1998, denominada Lei dos Crimes Ambientais.

A Lei n 6.902, de 27 de abril de 1981, que dispõe a criação de estações ecológicas e áreas de proteção ambiental, ao disciplinar como objeto de proteção a biota como um todo de um determinado território também se liga intrinsecamente à proteção da flora.

Em direção semelhante a Lei $\mathrm{n}^{\circ}$ 9.985, de 18 de julho de 2000, denominada de Lei do Sistema Nacional das Unidades de Conservação - SNUC, contribuiu enormemente para a proteção do patrimônio florestal, também inserindo-o como recurso ambiental de um determinado espaço territorial protegido e sob um regime especial de administração.

Lei $\mathrm{n}^{\mathrm{o}}$ 11.428, de 22 de dezembro de 2006, a Lei do Bioma Mata Atlântica, disciplina especificamente a conservação, proteção, regeneração e utilização do Bioma Mata Atlântica, definido como as formações florestais nativas e ecossistemas associados formados por Floresta Ombrófila Densa, Floresta Ombrófila Mista ("Mata de Araucárias"), Floresta Ombrófila Aberta, Floresta Estacional Semidecidual e Floresta Estacional Decidual, bem como manguezais, vegetações de restingas, campos de altitude, brejos interioranos e encraves florestais do Nordeste.

Finalmente, o marco regulatório das florestas públicas é a Lei n ${ }^{\circ} 11.284$, de 02 de março de 2006 (Lei Geral de Gestão das Florestas Públicas), instituiu o Serviço Florestal Brasileiro - SFB, na estrutura do Ministério do Meio Ambiente e criou o Fundo Nacional de Desenvolvimento Florestal - FNDF.

Tal lei foi regulamentada pelo Decreto n 6.063, de 20 de março de 2007, que também disciplina o Cadastro Nacional de Florestas Públicas, o Plano Anual de Outorga Florestal, entre outras especificidades da matéria.

Pela Resolução SFB nº 02, de 06 de julho de 2007, foi regulamentado o Cadastro Nacional de Florestas Públicas e foram definidos os tipos de vegetação e as formações de cobertura florestal, para fins de identificação das florestas públicas federais. 
Por intermédio da Portaria MMA n 430, de 31 de julho de 2007, foi tornado público o Plano Anual de Outorga Florestal - PAOF 2007/2008, instituído nos termos dos artigos 49, incisos I e II, e 51, inciso I, da Lei de Gestão das Florestas Públicas.

Denota-se, da descrição do bloco normativo de tutela do patrimônio florestal brasileiro, que as florestas existentes em terras públicas recebeu tratamento recente, principalmente quanto à sua exploração sustentável, sendo a compreensão de tal bloco um dos pontos principais desta tese.

\subsection{Classificação das florestas e demais formas de vegetação brasileiras.}

\subsubsection{Classificação técnica:}

No magistério de Américo Luís Martins da Silva ${ }^{62}$ encontra-se a divisão da cobertura florestal brasileira segundo regiões de ecossistemas florestais específicos, a saber:

a) Região da savana, que abrange o Cerrado;

b) Região da savana estépica, que abrange a Caatinga do sertão árido, os campos de Roraima, o chaco sul-matogrossense e o Parque do Espinilho;

c) Região de estepe, que abrange os compôs gerais planálticos e a campanha gaúcha;

d) Região de campinarama, que abrange as campinas do rio Negro;

e) Região de floresta ombrófila densa, que abrange a floresta tropical pluvial;

f) Região de floresta ombrófila aberta, que abrange as faciações da floresta ombrófila densa;

g) Região de floresta ombrófila mista, que abrange a floresta de araucária;

h) Região de floresta estacional semidecidual, que abrange a floresta tropical subcaducifólia;

i) Região de floresta estacional decidual, que abrange a floresta tropical caducifólia;

j) Áreas de formações pioneiras, que abrange ecossistemas associados, com influência marinha, fluviomarinha, fluvial ou lacustre;

k) Áreas de tensão ecológica, que abrange contatos entre tipos de vegetação;

1) Refúgio ecológico, que abrange as relíquias ecológicas.

Teresa Cristina de Deus ${ }^{63}$ divide as formações vegetais brasileiras em:

${ }^{62}$ Op. cit., p. 48-49

${ }^{63}$ Tutela da flora em face do direito ambiental brasileiro, São Paulo: Juarez de Oliveira, 2003. p. 22 
a) formações florestais: compostas por floresta latifoliada equatorial, floresta latifoliada tropical, floresta latifoliada tropical úmida da encosta e mata de araucária;

b) formações herbáceas, composta por campos;

c) formações complexas, compostas por cerrado, caatinga e complexo do Pantanal;

d) formações litorâneas, composta por vegetação do litoral.

Para Paulo Affonso Leme Machado ${ }^{64}$, os tipos de vegetação existentes no Brasil são os seguintes:

a) floresta latifoliada perene;

b) floresta latifoliada semidecídua;

c) floresta acicufoliada;

d) manguezal;

e) caatinga;

f) cerrado;

g) vegetação de praias e restingas;

h) vegetação mista de mata e campo;

i) complexo do pantanal;

j) vegetação campestre.

A diversidade de classificações técnicas existentes confirma a dificuldade da escolha de uma delas.

Relevante apontar, porém, que as diferentes formações vegetais brasileiras recebem proteção jurídica pela lei geral, o Código Florestal, como também por leis específicas, como a Lei $\mathrm{n}^{\circ} 11.428$, de 22 de dezembro de 2006 (Lei do Bioma Mata Atlântica) disciplina especificamente a conservação, proteção, regeneração e utilização do Bioma Mata Atlântica, definido como as formações florestais nativas e ecossistemas associados formados por Floresta Ombrófila Densa, Floresta Ombrófila Mista ("Mata de Araucárias”), Floresta Ombrófila Aberta, Floresta Estacional Semidecidual e Floresta Estacional Decidual, bem como manguezais, vegetações de restingas, campos de altitude, brejos interioranos e encraves florestais do Nordeste.

${ }^{64}$ Op. cit., p. $735-736$ 


\subsubsection{Classificações jurídicas legais e doutrinárias:}

Em que pese o título do presente tópico referir-se a classificações jurídicas legais e doutrinárias, deve-se anotar, preliminarmente, que inúmeros conceitos da classificação fitogeográfica são incorporados na legislação, por tratar-se mesmo de matéria com grande carga técnica.

Portanto, a diferenciação entre a classificação do tópico anterior com o presente, serve apenas para melhor descrição das florestas podendo, com isso, contribuir para a melhor compreensão do objeto de estudo.

Nesta toada, uma primeira tentativa de classificação das florestas brasileiras encontra-se no antigo Código Florestal, Decreto n ${ }^{\circ} 23.793$, de 23 de janeiro de 1934, em seus artigos $3^{\circ}$ a $7^{\circ}$, que assim dispunham:

a) protetoras: aquelas que, por sua localização, serviriam conjunta ou separadamente para conservar o regime das águas, evitar erosão das terras pela ação dos agentes naturais, fixar dunas, auxiliar a defesa de fronteiras, assegurar condições de salubridade pública, proteger sítios e asilar espécies raros da fauna indígena;

b) remanescentes: seriam aquelas declaradas pelo poder público para formação de parques nacionais, estaduais ou municipais, as que possuíssem espécies preciosas biológica ou esteticamente e aquelas reservadas pelo poder público para formação de pequenos parques ou bosques de gozo público;

c) modelo: seriam as florestas artificiais, formadas por uma espécie ou número limitado delas, indígenas ou exóticas, cuja disseminação conviesse fazer-se na região;

d) de rendimento: conceituadas por exclusão, seriam aquelas em que se exercesse a extração de elementos da fauna e produtos florestais como atividade comercial.

Essa classificação é de interesse apenas histórico, não possuindo aplicabilidade na atualidade, pois o atual Código Florestal (Lei $\mathrm{n}^{\circ} 4.771$, de 15 de setembro de 1965 e alterações posteriores) dispôs de forma diversa, podendo-se dele extrair mais de uma classificação, dependendo do critério diferenciador adotado.

Desta forma, é possível a construção de uma primeira classificação das florestas com base em dois critérios diferenciadores: a natureza jurídica do ato que a institui (se ato legislativo ou ato administrativo) e a função ambiental por elas desempenhada, como a proteção dos recursos hídricos, da fauna, entre outros.

Nestes moldes, as florestas podem ser assim classificadas:

a) florestas de preservação permanente por determinação legal $\left(\operatorname{artigo~} 2^{\circ}\right)$; 
b) florestas de preservação permanente por ato do poder público (artigo $3^{\circ}$ );

c) florestas de preservação permanente de indígenas $\left(\operatorname{artigo~} 3^{\circ}, \S 2^{\circ}\right)$.

As florestas de preservação permanente por determinação legal, disciplinadas no artigo $2^{\circ}$, do atual Código Florestal, por sua vez, são subdivididas em:

a) florestas de preservação permanente para proteção dos cursos d’água, também denominadas de "matas ciliares";

b) florestas de preservação permanente para proteção das encostas e elevações;

c) florestas de preservação permanente para proteção das restingas;

d) florestas de preservação permanente em regiões urbanas.

As florestas de preservação permanente por ato do poder público, disciplinadas no artigo $3^{\circ}$, do atual Código Florestal, são subdivididas em:

a) florestas de preservação permanente para atenuar erosão das terras;

b) florestas de preservação permanente para fixar as dunas;

c) florestas de preservação permanente para formação de faixas de proteção ao longo de rodovias e ferrovias;

d) florestas de preservação permanente para auxílio na defesa do território nacional;

e) florestas de preservação permanente para proteção de sítios de excepcional beleza ou de valor científico ou histórico;

f) florestas de preservação permanente para asilo de exemplares da fauna e flora ameaçados de extinção;

g) florestas de preservação permanente para manutenção do ambiente necessário à vida das populações silvícolas;

h) florestas de preservação permanente para assegurar condições de bem-estar público.

José Afonso da Silva ${ }^{65}$ entende que o atual Código Florestal, ao contrário do antigo, não adotou uma classificação para as florestas, "conquanto dele decorra o reconhecimento de vários tipos delas". O doutrinador assinalou os seguintes tipos:

a) florestas nativas, florestas primitivas, florestas regeneradas e florestas artificiais ou plantadas (artigos 12, 15, 16 e 46);

b) florestas heterogêneas e florestas homogêneas;

c) florestas de preservação permanente e florestas não preservadas ( $\operatorname{artigos} 2^{\circ}, 3^{\circ}$ e $6^{\circ}$ );

d) florestas de livre exploração (plantadas); florestas de exploração limitada florestas de exploração permitida com restrições (artigos 10, 12 e 16);

\footnotetext{
${ }^{65}$ Direito Ambiental Constitucional, $3^{\mathrm{a}}$ ed., São Paulo: Malheiros Editores, 2000. p. 162
} 
e) florestas de domínio público (nacionais, estaduais e municipais) e florestas de domínio particular (artigos 50, "b”, $9^{\circ}$ e 16).

Para ele, o código adotou uma "tipologia inorgânica, assistemática, mais valendo como conceitos lançados aqui e ali", "sem normatividade precisa", mas relevante por tratar-se da base de sustentação do regime de exploração e conservação florestal.

Por outro lado, deve-se notar que na organização dos tipos de florestas procedida pelo citado doutrinador, apesar de, segundo seu próprio entendimento, não se tratar de uma classificação propriamente dita, foram adotados como elementos diferenciadores critérios de existência ou não da ação antrópica na sua formação, a existência ou não de exploração e a titularidade do domínio. Ou seja, tais critérios, em princípio, são aptos para diferenciar os vários tipos de florestas encontrados, de forma implícita ou explícita, no atual Código Florestal.

Conforme apontado por Paulo Affonso Leme Machado ${ }^{66}$, "classificar as florestas não é tarefa isenta de dificuldades, pois depende muito dos critérios adotados", sendo que, para ele, "atualmente temos florestas a serem preservadas e florestas de rendimento". Portanto, o critério diferenciador adotado pelo doutrinador refere-se à exploração da floresta.

Neste ponto, cabível anotar que a expressão "florestas de rendimento", adotada pelo doutrinador, não corresponde à terminologia adotada no antigo Código Florestal, mas ao que prevê o artigo 12, do atual Código Florestal, as florestas plantadas, não consideradas de preservação permanente, em que há liberdade para a extração de lenha e demais produtos florestais ou a fabricação de carvão.

Celso Antonio Pacheco Fiorillo ${ }^{67}$ prefere uma classificação baseada nos critérios da preservação, da variabilidade das espécies, do tipo de reposição florestal, do primitivismo e da exploração, assim divididos:

a) quanto à preservação: as florestas podem ser permanentes e não permanentes. As permanentes são aquelas previstas nos artigos $2^{\circ}$ e $3^{\circ}$, do Código Florestal. Em conseqüência, as não permanentes são residuais, sendo todas aquelas que não se amoldarem aos conceitos dos referidos dispositivos;

b) quanto à variabilidade de espécies: as florestas podem ser homogêneas ou heterogêneas. As homogêneas são constituídas pela dominância de determinada espécie, enquanto as heterogêneas por uma grande diversidade genética e de ecossistemas.

\footnotetext{
${ }^{66}$ Direito Ambiental Brasileiro, $15^{\mathrm{a}}$ ed., São Paulo: Malheiros, 2007. p. 736

${ }^{67}$ Curso de Direito Ambiental Brasileiro, $9^{a}$ ed., São Paulo:Saraiva, 2008. p. 116-120
} 
c) quanto ao tipo de reposição florestal: as florestas podem ser nativas ou exóticas. Nativas são aquelas formadas por espécies que possuem identidade com a região. Exóticas são aquelas formadas por espécies alienígenas, estranhas à identidade de espécies regionais. d) quanto ao primitivismo: as florestas podem ser primitivas (virgens) ou secundárias. As secundárias, por sua vez, podem ser regeneradas ou plantadas. As florestas primitivas ou virgens são aquelas que não sofreram ação antrópica. As florestas secundárias regeneradas são aquelas que se recompõem a partir de espécies nativas, enquanto as florestas secundárias plantadas são aquelas que decorrem da ação humana, por isso também denominadas artificiais;

e) quanto à exploração: as florestas podem ser inexploráveis ou exploráveis. As florestas inexploráveis são, por exemplo, aquelas previstas nos artigos $2^{\circ}$ e $3^{\circ}$, do Código Florestal (florestas de preservação permanente por ato legal ou administrativo), as Unidades de Proteção Integral previstas na Lei no 9.985, de 18 de julho de 2000, aquelas sobre a qual recaia a proibição de corte prevista no artigo $7^{\circ}$, do Código Florestal, entre outras. As florestas exploráveis são subdivididas em florestas de rendimento permanente e florestas com restrições. As florestas de rendimento permanente seriam aquelas previstas no artigo 10, do Código Florestal, que proíbe a derrubada de florestas situadas em áreas de inclinação entre vinte e cinco e quarenta e cinco graus, podendo haver, porém, extração de madeira em regime de utilização racional. As florestas exploráveis com restrições são aquelas previstas nos artigos 15 e 16, do Código Florestal, nas quais é permitida a exploração desde que conforme um plano de manejo racional devidamente aprovado pelos órgãos reguladores.

A classificação proposta por Luís Paulo Sirvinskas ${ }^{68}$ alicerça-se em três critérios: a titularidade, a origem e ao uso. Quanto a titularidade, as florestas podem ser de domínio público ou de domínio privado. Para ele, as de domínio público seriam aquelas instituídas na forma dos artigos $2^{\circ}$ e $3^{\circ}$, do Código Florestal, ou seja, as florestas de preservação permanente previstas em ato legislativo e as declaradas por ato administrativo.

Quanto à origem, no seu entender, as florestas podem ser:

a) primitivas (primárias, nativas, natural ou virgem): constituídas por espécies do país e da região;

b) em regeneração: a floresta que se encontra em fase de reconstituição após destruição;

${ }^{68}$ Manual de Direito Ambiental, São Paulo: Saraiva, 2008. p. 388 
c) regenerada: a floresta que foi reconstituída por meios naturais, sem intervenção do homem;

d) plantada: a floresta reconstituída por meio da ação humana por florestamento ou reflorestamento, podendo ser natural ou artificial, a depender do fato da espécie utilizada ser ou não exótica.

Finalmente, quanto ao uso, as florestas podem ser: de exploração proibida ou de exploração limitada, esta última dependente de autorização do órgão federal regulador.

Da comparação das classificações propostas por Celso Antonio Pacheco Fiorillo e Luís Paulo Sirvinskas, conclui-se que este último usa como sinônimo de floresta primitiva o termo "nativas", que, para o primeiro, aplica-se a outro critério de classificação, a reposição florestal.

Segundo a classificação de Celso Antonio Pacheco Fiorillo, uma floresta primitiva (virgem, intocada) sempre é nativa (constituída por espécies da região), mas o contrário nem sempre ocorre. Ou seja, é possível existir uma floresta constituída por espécies nativas que tenha sido produto da ação humana (floresta plantada).

Em todas as classificações retro descritas é possível constatar-se que foram inspiradas em dispositivos do Código Florestal, sendo todas servíveis para a melhor compreensão do objeto de estudo, no caso, as florestas.

É inegável também que a conceituação dos inúmeros tipos de floresta possui utilidade prática, na medida em que a legislação pode incidir sobre eles dispensando diferentes tratamentos, como, por exemplo, na aplicação das regras de manejo ou na aplicação de sanções em razão da degradação florestal.

A existência de diferentes biomas protegidos pela legislação, assunto adiante melhor detalhado, também justifica a utilidade prática da tipologia das florestas e demais formas de vegetação brasileiras.

\subsection{Competências em matéria florestal.}

O artigo 23, inciso VII, da Constituição Federal, prevê que é competência comum da União, Estados, Distrito Federal e Municípios preservar "as florestas, a fauna e a flora".

Trata-se esta da competência material, sendo que a repetição dos termos "florestas" e "flora" é considerada falta de precisão técnica, redundância no texto 
constitucional, pois, conforme demonstrado no início deste capítulo, floresta é espécie de flora, por isso bastando a menção apenas a este último termo, mais amplo, para se garantir a referida proteção.

No artigo 225, $\S 1^{\circ}$, inciso VII, da Constituição Federal, por exemplo, foi prevista a incumbência do poder público "proteger a fauna e a flora", sem qualquer menção ao termo mais restrito "floresta".

Quanto à competência para legislar, prevê o artigo 24, inciso VI, da Constituição Federal que é concorrente em relação às "florestas", neste ponto, portanto, tendo sido empregado o termo mais restritivo, o que não é considerado como uma vedação à legislação sobre a flora propriamente.

Constata-se, assim, que há imprecisão no texto constitucional na repetição de termos designativos de um mesmo objeto na competência material e na utilização de um termo mais restritivo na competência legislativa.

A competência legislativa concorrente constitui-se inovação em relação à tradição constitucional brasileira, pois, desde a Constituição Federal de 1934, tal competência era exclusiva da União, fato este anotado por José Afonso da Silva ${ }^{69}$ : "A Constituição de 1934 foi a primeira a dispor sobre florestas, ao reconhecer a competência privativa da União para legislar sobre elas e sua exploração. Nesse sentido dispuseram as demais até a de 1988, que inovou na matéria".

$\mathrm{Na}$ visão do mesmo doutrinador, mesmo antes da alteração no texto constitucional de 1988, havia na legislação e em especial no Código Florestal de 1965, ainda em vigor, dispositivos que prescreviam competência aos Estados para legislar sobre a matéria florestal.

Portanto, os Estados, o Distrito Federal e os Municípios detêm competência para legislar sobre a flora, detalhando as disposições gerais da lei federal, que possui caráter de norma geral.

No âmbito interno de cada ente federativo, a competência para a propositura de projetos de lei em matéria ambiental, aí se incluindo a matéria florestal, também é concorrente, entre os membros do Poder Legislativo e o Chefe do Poder Executivo, uma vez que a Constituição Federal não inclui tal matéria entre aquelas de competência privativa deste último.

${ }^{69}$ Op. cit., p. 160 
Deve-se asseverar, entretanto, que a competência legislativa concorrente, quando manejada por parlamentares, deve respeitar a regra da independência e harmonia entre os Poderes, prevista no artigo $2^{\circ}$, da Constituição Federal, não criando ônus e despesas, por exemplo, ao Poder Executivo.

Aos Estados a Constituição Federal, no artigo 24, §2º, confere a competência suplementar e, no $\S 3^{\circ}$, a competência plena, caso a União não estabeleça normas gerais sobre a matéria.

Os Municípios, no exercício da competência de legislar sobre assuntos de interesse local, conforme artigo 30, inciso I, da Constituição Federal, também poderão disciplinar a matéria florestal, respeitadas as normas gerais estaduais e nacionais.

Este também é o entendimento de Giuliano Deboni ${ }^{70}$ ao defender que, não obstante o artigo 24, da Constituição Federal, não mencionar expressamente os Municípios, “(...) é possível estes legislar sobre a flora local e sobre áreas verdes, por expressa disposição dos incisos I e II do art. 30 da Constituição Federal”, ressalvando, porém, “(...) que não cabe ao Município, dentro do interesse local, é extrapolar seus limites espaciais. Tanto é assim que a Constituição não faz qualquer limitação acerca de assuntos e situações, a não ser a geográfica."

Na mesma senda é a doutrina de Edis Milaré ${ }^{71}$, com a qual se concorda, que entende que a ausência de menção ao Município no citado dispositivo constitucional, "tem levado à conclusão precipitada de que ele não tem competência normativa em matéria ambiental" e conclui: "Levado ao pé da letra tal entendimento, chegar-se-ia ao absurdo de sustentar também que ele não tem competência para legislar sobre urbanismo, por ser matéria de competência concorrente incluída no art. 24. É evidente o disparate!”.

\subsection{Instrumentos de proteção da flora previstos na legislação.}

\subsubsection{Da proteção de um elemento do ecossistema para a proteção dos biomas.}

A Constituição Federal de 1988, em seu artigo 225, inciso III, também inovou na ordem jurídica ao determinar que o Poder Público deve "definir, em todas as unidades da Federação, espaços territoriais e seus componentes a serem especialmente

\footnotetext{
${ }^{70}$ Florestas: Competência para Legislar e Fiscalizar, Revista Magister de Direito Ambiental e Urbanístico, ano III, n. 14, out.-nov./2007, p. 81-101

${ }^{71}$ Direito do Ambiente, São Paulo: Revista dos Tribunais, 2005. p. 243
} 
protegidos, sendo a alteração e a supressão permitidas somente através de lei, vedada qualquer utilização que comprometa a integridade dos atributos que justifiquem sua proteção".

Essa regra constitucional baseou-se na idéia de que a melhor proteção do meio ambiente se concretiza pelo resguardo de um espaço territorial com seus componentes reunidos e em interação (entenda-se flora, fauna, recursos hídricos etc), enfim, um ecossistema, ao invés de cada um dos elementos separadamente, como era a comum estar previsto na legislação anterior.

No âmbito da flora, por exemplo, o Código Florestal inaugurou o conceito de florestas de preservação permanente em sua redação original de 1965 e, no ano de 2001, por intermédio da Medida Provisória $\mathrm{n}^{\circ}$ 2.166-67, tal conceito foi incrementado para área de preservação permanente, independentemente de ela estar ou não coberta pela floresta ou outro tipo de vegetação.

Após a edição da Lei nº 9.985, de 18 de julho de 2000 (Lei do Sistema Nacional das Unidades de Conservação) e Lei n ${ }^{\circ}$ 11.428, de 22 de dezembro de 2006, consolidou-se a idéia da preservação dos ecossistemas nas unidades de conservação e, mais ainda, dos biomas.

A sucessão da disciplina legal espelha uma evolução conceitual de proteção ambiental, em especial da flora, partindo-se da idéia de preservação de um elemento do ecossistema, no caso exemplificado a floresta, para a preservação de uma área que abriga tal ecossistema e, posteriormente, o reconhecimento da especialidade dos ecossistemas componentes de determinado bioma.

Clarifica-se o mencionado aperfeiçoamento nas definições técnicas de ecossistema e bioma.

Considera-se ecossistema o conjunto formado por comunidades que interagem em determinado território, inclusive com os elementos abióticos. A interação da biota (seres vivos) entre si e com os citados elementos abióticos (recursos hídricos, clima etc).

E considera-se bioma um conjunto de ecossistemas, uma comunidade biológica com condições ambientais específicas, tais como determinadas flora e fauna.

Portanto, no conceito de bioma se inclui o de ecossistema e, neste último, o conceito de flora, por exemplo, que compõe, juntamente com outros elementos, o ecossistema. 
Luís Carlos Silva de Moraes $^{72}$ explora a mesma idéia ao defender que a proteção ambiental, constante na Constituição Federal, se alicerça, primeiro, na individualização do ecossistema a ser protegido; segundo, na identificação objetiva da área em que esse ecossistema se situa e, terceiro, nas medidas biológicas e jurídicas necessárias para se garantir a efetividade do comando constitucional, caso a caso.

Em outras palavras, há uma centralidade da preservação do ecossistema como um todo nas disposições constitucionais e não apenas a preservação de um ou outro elemento específico do meio ambiente.

A exposição inicial deste tema visa demonstrar que a legislação que dispõe sobre a proteção da flora brasileira, ao evoluir da proteção da floresta para a proteção dos biomas em que aquelas se inserem, aperfeiçoou instrumentos para a citada proteção.

Para melhor esclarecimento, então, propõe-se uma organização e enfrentamento de tais instrumentos segundo os diplomas legais que os instituiu e aperfeiçoou, partindo-se daqueles previstos no Código Florestal, passando-se pela Lei do Sistema Nacional de Unidades de Conservação e pela Lei de Proteção do Bioma Mata Atlântica, o que é desenvolvido em cada subtópico seguinte.

\subsubsection{Espaços territoriais especialmente protegidos.}

Em razão do contido no artigo $225, \S^{\circ}$, inciso III, da Constituição Federal, construiu-se o conceito amplo de espaços territoriais especialmente protegidos, cuja instituição é uma obrigação imposta ao poder público, sendo sua alteração e supressão permitidas somente por meio de lei.

Polyana Faria Pereira e Fernando Paiva Scardua ${ }^{73}$ anotam que, segundo José Afonso da Silva, tais espaços territoriais especialmente protegidos são similares aos “espaces naturels sensibles” do direito ambiental francês.

O conceito de espaços territoriais especialmente protegidos, construído a partir do citado dispositivo constitucional, agasalha conceitos criados em legislação anterior e posterior a edição da Constituição Federal.

\footnotetext{
${ }^{72}$ Código Florestal Comentado, São Paulo: Atlas, 2009. p. 242

${ }^{73}$ Espaços territoriais especialmente protegidos: conceito e implicações jurídicas, in Ambiente \& Sociedade, Campinas, v. XI, n. 1, p. 81-97, jan.-jun. 2008
} 
Também, dentro do conceito mais amplo de espaços territoriais especialmente protegidos encontra-se o conceito de áreas protegidas, que, conforme o artigo $2^{\circ}$, da Convenção da Diversidade Biológica, é “área definida geograficamente que é destinada, ou regulamentada, e administrada para alcançar objetivos específicos de conservação".

Essa Convenção foi subscrita pelo Presidente da República na Conferência das Nações Unidas sobre Meio Ambiente e Desenvolvimento, em junho de 1992 e ratificada pelo Congresso Nacional pelo Decreto Legislativo ${ }^{\circ}{ }^{2}$, de 8 de fevereiro de 1994 e promulgada pelo Decreto n ${ }^{\circ}$ 2.519, de 17 de março de 1998 estando, portanto, devidamente internalizada na ordem legal nacional.

Para regulamentar as disposições da referida Convenção, o governo federal editou o Decreto $\mathrm{n}^{\mathrm{o}}$ 5.758, de 13 de abril de 2006, pelo qual instituiu o Plano Estratégico Nacional de Áreas Protegidas - PNAP, que também alinhavou as espécies de áreas protegidas. Assim, segundo tal decreto, as áreas protegidas são um gênero do qual são espécies:

a) áreas terrestres e marinhas do Sistema Nacional de Unidades de Conservação;

b) terras indígenas;

c) territórios quilombolas;

d) áreas de preservação permanente;

e) reserva florestal legal.

Denota-se, conforme aludido, que são espécies de espaços territorialmente protegidos as áreas de preservação permanente e reserva florestal legal disciplinadas pelo Código Florestal, lei anterior à Constituição Federal e aos diplomas legais que disciplinam as áreas protegidas.

Entretanto, o gênero espaços territoriais especialmente protegidos admite as seguintes espécies, que englobam aquelas retro referidas, previstas no Decreto $\mathrm{n}^{\circ} 5.758$, de 13 de abril de 2006.

Nesta senda, Polyana Faria Pereira e Fernando Paiva Scardua ${ }^{74}$ apresentam as seguintes espécies de espaços territoriais especialmente protegidos:

a) as unidades de conservação da Lei $n^{\circ}$ 9.985, de 18 de julho de 2000 (Lei do Sistema Nacional das Unidades de Conservação);

b) áreas destinadas às comunidades tradicionais, sejam indígenas ou quilombolas;

\footnotetext{
${ }^{74}$ Loc. cit.
} 
c) áreas tombadas por razões ambientais;

d) monumentos arqueológicos e pré-históricos;

e) áreas especiais e locais de interesse turístico, destinados à prática do ecoturismo;

f) as reservas da biosfera;

g) os corredores ecológicos;

h) as zonas de amortecimento;

i) os espaços protegidos constitucionalmente como patrimônio nacional: Floresta Amazônica, Mata Atlântica, Serra do Mar, Zona Costeira e Pantanal Matogrossense;

j) as áreas de proteção especial, destinadas à gestão ambiental urbana;

k) os jardins botânicos;

1) os hortos florestais;

m) os jardins zoológicos;

n) as terras devolutas e arrecadadas, necessárias à proteção dos ecossistemas naturais;

o) as áreas de preservação permanente e as reservas legais, disciplinadas pelo Código Florestal;

p) os megaespaços ambientais protegidos por normas internacionais, tais como: Convenção das Nações Unidas sobre o Direito do Mar, o Tratado da Bacia do Prata, o Tratado de Cooperação Amazônica, a Convenção Relativa a Zonas Úmidas de Importância Internacional e a Convenção Relativa à Proteção do Patrimônio Mundial Cultural e Natural.

Luis Paulo Sirvinskas ${ }^{75}$, a respeito do tema assim conclui:

A regra constitucional, segundo Edis Milaré, Paulo Affonso Leme Machado, Antônio Herman Benjamin, Paulo Bessa Antunes, não se restringiu somente às unidades de conservação. Os espaços territoriais especialmente protegidos são considerados gênero, tendo como espécies as Unidades de Conservação, a Reserva Legal e a Área de Preservação Permanente (APP). Cada uma dessas modalidades possui regime jurídico específico. (grifo nosso)

O objetivo da exposição deste tópico é demonstrar que os instrumentos legais de defesa da flora inserem-se entre os espaços territoriais especialmente protegidos, conforme a mais atual disciplina da matéria no direito ambiental.

Desta forma, nos subtópicos seguintes não se analisam apenas instrumentos de defesa da flora, mas sim instrumentos de defesa de ecossistemas e biomas

${ }^{75}$ Op. cit., p. 394 
em espaços territoriais especialmente protegidos, atendendo-se o mandamento constitucional.

Não é demasiado concluir, em conseqüência, que há uma sobreposição de regimes jurídicos que devem ser interpretados conjuntamente até mesmo em razão de um princípio de proteção integral do meio ambiente.

Abordados tais aspectos iniciais, adentra-se nos principais instrumentos legais de defesa da flora.

\subsection{3 Área de preservação permanente.}

\subsubsection{Conceito legal e evolução da disciplina no Código Florestal:}

No artigo $4^{\circ}$, do Decreto $\mathrm{n}^{\circ}$ 23.793, de 23 de janeiro de 1934, antigo Código Florestal, havia a previsão de florestas protetoras com funções ambientais bastante semelhantes a da atual área de preservação permanente.

Porém, a área de preservação permanente insere-se na moderna realidade ambiental, em que se deve proporcionar a proteção integral de um ecossistema e não apenas de um dos elementos do meio ambiente, no caso a flora, o que é confirmado por Ângela Aparecida Napolitano e Ângela Issa Haonat ${ }^{76}$, em relação à antiga disciplina do Código Florestal:

Antes, muitos entendiam que o que merecia proteção eram
apenas as florestas e as demais formas de vegetação que
recobriam estas áreas. O que pode ser considerado um
entendimento equivocado. O que merece proteção são as
áreas de preservação permanente de maneira holística,
estejam ou não recobertas por florestas ou vegetações. (grifo
nosso)

Em razão dessa nova realidade que também foi modificada a redação original do Código Florestal atualmente em vigor, Lei $\mathrm{n}^{\mathrm{o}} 4.771$, de 15 de setembro de 1965, para inclusão, em seu inciso II, do $\S 2^{\circ}$, do artigo $1^{\circ}$, do conceito de área de preservação permanente, como sendo: "área protegida nos termos dos arts. $2^{\circ}$ e $3^{\circ}$ desta Lei, coberta ou não por vegetação nativa, com a função ambiental de preservar os recursos

\footnotetext{
${ }^{76}$ Recomposição Florestal em APPs pelo Poder Público: Análise do Artigo 18 do Código Florestal, in Revista de Direitos Difusos, São Paulo, ano VI, vol. 31, maio-jun. 2005, p. 1126 - 137
} 
hídricos, a paisagem, a estabilidade geológica, a biodiversidade, o fluxo gênico de fauna e flora, proteger o solo e assegurar o bem-estar das populações humanas" (grifo nosso).

Esta modificação ocorreu por força da Medida Provisória nº 2.166-676, de 2001, sendo que antes dela a disposição do código era de que somente as florestas eram de preservação permanente e não propriamente as áreas nas quais se localizavam, o que é confirmado pelo próprio teor do inciso incluído referente a uma "área protegida (...) coberta ou não por vegetação nativa".

Este também é o entendimento de Fernanda de Salles Cavedon, Ricardo Stanziola Vieira e Francelise Pantoja Diehl ${ }^{77}$ :

Deve-se ressaltar que o Código Florestal não utilizava a expressão "áreas de preservação permanente", que foi sendo forjada no processo de interpretação e aplicação da norma, sendo posteriormente introduzida no Código, em seu artigo $1^{\circ}, \S 2^{\circ}$, II, com redação dada pela Medida Provisória $\mathrm{n}^{\circ}$ 2.166-67/01, que fixou o seu conceito (...).

Desta forma, a alteração do Código Florestal acabou por adaptá-lo à disciplina jurídica de defesa do ecossistema da área como um todo e não apenas de um dos seus elementos, o que também confirma o fato de ser tal área uma espécie de espaço territorial especialmente protegido, conforme prevê o artigo $225, \S 1^{\circ}$, inciso III, da Constituição Federal, conforme exposto no tópico precedente.

\subsubsection{Tipologia das áreas de preservação permanente:}

Quanto aos tipos de áreas de preservação permanente, segue-se classificação assemelhada àquela adotada para as florestas, exposta no tópico 1.5.2 supra, podendo-se afirmar que existem basicamente:

a) áreas de preservação permanente por determinação legal, previstas no artigo $2^{\circ}$, do Código Florestal, podendo ser denominadas simplesmente de "áreas de preservação permanente legais";

b) áreas de preservação permanente declaradas por ato do poder público, previstas no artigo $3^{\circ}$, do Código Florestal, podendo ser denominadas simplesmente "áreas de preservação permanente administrativas".

\footnotetext{
${ }^{77}$ Regime Jurídico das Áreas de Preservação Permanente e Desenvolvimento Econômico. Conciliação ou Flexibilização? in Revista de Direitos Difusos, Meio Ambiente, Saúde e Desenvolvimento Econômico I, São Paulo, ano VIII, vol. 43, jul.-set. 2007, p. 15 - 37
} 
Antonio Herman de Vasconcellos e Benjamin ${ }^{78}$ também adota tais denominações, justificando que são chamadas de áreas de preservação permanente legais "porque sua delimitação ocorre no próprio Código Florestal” e de áreas de preservação permanente administrativas "porque sua concreção final depende de expedição de ato administrativo da autoridade ambiental competente".

As áreas de preservação permanente legais são as que se encontram a certa distância de cursos d'água, ao redor de lagoas, lagos ou reservatórios d'água naturais ou artificiais, nas nascentes e olhos d'água, no topo de morros, montes, montanhas, serras, nas encostas e elevações, nas restingas, como fixadoras de dunas, estabilizadoras de mangue, nas bordas dos tabuleiros ou chapadas, em altitude superior a mil e oitocentos metros, qualquer que seja a vegetação.

Especialmente para as áreas de preservação permanente legais protetoras de cursos d'água, deve-se notar que são medidas "desde o nível mais alto em faixa marginal"79 de tal curso e respeitam as seguintes larguras mínimas:

a) de trinta metros para cursos d'água de menos de dez metros de largura;

b) de cinqüenta metros para cursos d'água que tenham entre dez e cinqüenta metros de largura;

c) de cem metros para cursos d'água que tenham de cinqüenta a duzentos metros de largura;

d) de duzentos metros para cursos d'água que tenham de duzentos a seiscentos metros de largura;

e) de quinhentos metros para cursos d'água que tenham largura superior a seiscentos metros.

Em relação às áreas de preservação permanente legais protetoras de nascentes e olhos d'água, em qualquer tipo de topografia, a largura é de um raio mínimo de cinqüienta metros.

As áreas de preservação permanente legais em encostas ou partes destas, com declividade superior a quarenta e cinco graus, deve ser equivalente a cem por cento na linha de maior declive [artigo $2^{\circ}$, alínea e), do Código Florestal].

\footnotetext{
${ }^{78}$ Reflexões sobre a Hipertrofia do Direito de Propriedade na Tutela da Reserva Legal e das Áreas de Preservação Permanente. Anais do Congresso Internacional de Direito Ambiental, 5 anos após a ECO-92, São Paulo, 1997. p. 26

${ }^{79}$ Segundo definição constante no inciso I, do artigo $2^{\circ}$, da Resolução CONAMA n ${ }^{\circ} 303$, de 20 de março de 2003, "nível mais alto: nível alcançado por ocasião da cheia sazonal do curso d'água perene ou intermitente".
} 
As áreas de preservação permanente legais localizadas em bordas dos tabuleiros ou chapadas devem ser contadas a partir da linha de ruptura do relevo em faixa nunca inferior a cem metros em projeções horizontais.

As áreas de preservação permanentes administrativas disciplinadas no artigo $3^{\circ}$, do Código Florestal, são destinadas a:

a) atenuar erosão das terras;

b) fixar as dunas;

c) formar faixas de proteção ao longo de rodovias e ferrovias;

d) auxiliar a defesa do território nacional a critério das autoridades militares;

e) proteger sítios de excepcional beleza ou de valor científico ou histórico;

f) asilar exemplares da fauna e flora ameaçados de extinção;

g) manter o ambiente necessário à vida das populações silvícolas;

h) assegurar condições de bem-estar público.

Denota-se que a verificação das situações que justificam a declaração de uma área de preservação permanente administrativa depende de uma análise técnica por parte do órgão ambiental competente, disso também se confirmando a discricionariedade opinião esta compartilhada com Luís Paulo Sirvinskas ${ }^{80}$ :

O Poder Público decidirá da conveniência ou não da necessidade de instituir áreas de preservação permanente. Essas áreas só poderão ser criadas com base nos critérios preestabelecidos por lei, utilizando-se, é claro, do seu poder discricionário.

O exercício de tal competência discricionária pelo poder público deverá observar o princípio da proporcionalidade, para que não haja esvaziamento da função econômica da propriedade privada, ou seja, é necessário o equilíbrio na fixação das áreas de preservação permanente do artigo $3^{\circ}$, do Código Florestal, equilibrando-se a função ambiental com um mínimo de manutenção do aproveitamento econômico da propriedade.

A competência para declarar as áreas de preservação permanente administrativas, segundo entendimento de José Afonso da Silva ${ }^{81}$, é de qualquer ente federativo, em atendimento ao artigo 23, inciso VIII, da Constituição Federal, que prevê a competência comum material em matéria de preservação das florestas.

${ }^{80}$ Manual de Direito Ambiental, São Paulo: Saraiva, 2008. p. 402

${ }^{81}$ Op. cit., p. 164 
Na mesma direção Eliana Goulart Leão de Faria ${ }^{82}$ explica:

Por "ato do Poder Público" entenda-se, neste caso, ato da Administração Federal, Estadual ou Municipal, já que as autoridades pertencentes às três esferas de governo são competentes para tanto, conforme seja, o interesse determinante da providência a ser adotada em cada caso, geral, regional ou local.

Quanto a localização, a rigor, as áreas de preservação permanente, tanto para as legais, quanto para as administrativas, são somente aquelas áreas localizadas na zona rural, havendo, porém, discussão a respeito da adoção do regime jurídico das áreas de preservação permanente também na zona urbana, o que é exposto com mais detalhes adiante.

1.7.3.3 Normas regulamentares e a supressão total ou parcial da área de preservação permanente:

A Resolução CONAMA n ${ }^{\circ}$ 302, de 20 de março de 2002, disciplina parâmetros, definições e limites de áreas de preservação permanente no entorno de reservatórios artificiais, estabelecendo um regime de uso, com isso regulamentando a previsão do artigo $2^{\circ}$, alínea b) e $\S 6^{\circ}$, do artigo $4^{\circ}$, todos do Código Florestal, que, de forma genérica, não previu os citados limites.

Na mencionada resolução são previstas as larguras mínimas das áreas de preservação permanente em entorno de reservatórios artificiais, medidas do nível máximo normal, sendo de:

a) trinta metros, quando o reservatório artificial estiver situado em zona urbana e de cem metros para aqueles situados na zona rural;

b) quinze metros para os reservatórios de geração de energia elétrica com até dez hectares, sem prejuízo de compensação ambiental;

c) quinze metros, no mínimo, para reservatórios artificiais não utilizados em abastecimento público ou geração de energia elétrica, com até vinte hectares de superfície e localizados em zona rural.

${ }^{82}$ O Código Florestal Brasileiro e seu Aperfeiçoamento, in DALLARI, Adilson Abreu. FIGUEIREDO, Lucia Valle. (coord.) Temas de Direito Urbanístico, São Paulo: Editora Revista dos Tribunais, 1987. p. 74 - 106 
Denota-se que as áreas de preservação permanente possuem diferentes medidas a depender do tipo de reservatório e se é destinada à geração de energia elétrica ou ao abastecimento público, conjugadas ou não tais finalidades.

Ainda, segundo a referida norma administrativa, os limites das áreas de preservação permanente ao redor de reservatórios poderão ser ampliados ou reduzidos, observado sempre um patamar mínimo de trinta metros, dependendo de licenciamento ambiental e plano de recursos hídricos da bacia onde o reservatório se inserir, independentemente deles estarem localizados em zona urbana ou rural.

Quanto aos reservatórios utilizados na geração de energia elétrica e/ou abastecimento público, só é permitida a ampliação também dependente de licenciamento ambiental e plano de recursos hídricos da bacia que os abrigar.

Em qualquer dos casos, o impacto ambiental causado pela implantação do reservatório deverá ser analisado, assim como as características ambientais e fisiografia da bacia hidrográfica, tipologia vegetal, representatividade ecológica da área no bioma presente dentro da citada bacia, especialmente a existência de espécimes ameaçadas de extinção, finalidade do uso da água e uso e ocupação do solo no entorno.

Para os reservatórios artificiais destinados à geração de energia e abastecimento público, o empreendedor deverá elaborar um plano ambiental de conservação e uso do entorno do reservatório junto ao procedimento de licenciamento ambiental.

A Resolução CONAMA nº 303, de 20 de março de 2002, dispõe sobre os parâmetros, definições e limites das áreas de preservação permanente, constituindo norma administrativa de suma importância para definir os conceitos necessários ao estabelecimento de tais áreas.

Diferentemente da resolução anterior, que disciplina áreas de preservação permanente no entorno de reservatórios artificiais de água, a Resolução $n^{\circ} 303$, de 20 de março de 2002, disciplina as metragens para aquelas situadas no entorno de lagos e lagoas naturais, da seguinte forma:

a) trinta metros, para os que estejam situados em áreas urbanas consolidadas;

b) cem metros, para as que estejam em áreas rurais, exceto corpos d'água com até vinte hectares de superfície, cuja faixa marginal será de cinqüenta metros.

A resolução também detalha as áreas de preservação permanente existentes em morros, montanhas, encostas, escarpas e bordas dos tabuleiros e chapadas, restingas, manguezal, duna, em altitude superior a mil e oitocentos metros, locais de 
refúgio ou reprodução de aves migratórias, praias e locais de nidificação e reprodução da fauna silvestre.

Portanto, a Resolução $n^{\circ}$ 303, de 20 de março de 2002, regulamenta não só as alíneas b) a h), do artigo $2^{\circ}$, do Código Florestal, como também amplia o rol de locais em que as APPs deverão ser preservadas.

Se as duas resoluções anteriores tratam de regulamentar, principalmente, características e limites das áreas de preservação permanente não definidos pelo Código Florestal, a Resolução n 396, de 28 de março de 2006, de edição mais recente, detalha as situações de utilidade pública, interesse social e baixo impacto ambiental que justificam a intervenção ou supressão de vegetação em áreas de preservação permanente, situações estas previstas de forma ampla no artigo $3^{\circ}, \S 1^{\circ}$ e artigo $4^{\circ}$, todos do mesmo código.

Não se pode olvidar que, no regime jurídico das áreas de preservação permanente a intervenção humana deve ser excepcional, sendo que, na redação original do Código Florestal, tal intervenção era permitida somente nas áreas de preservação permanente administrativas, o que foi alterado pela Medida Provisória $n^{\circ}$ 2.166-67, de 2001 que permitiu também a alteração em áreas de preservação permanente legais.

No artigo $4^{\circ}$, do Código Florestal, é disciplinada a supressão total ou parcial de vegetação das áreas de preservação permanente, dependente de autorização administrativa, nas hipóteses de utilidade pública ou de interesse social, devidamente caracterizados em procedimento próprio, quando não existir alternativa técnica e locacional ao empreendimento proposto.

Pela atual sistemática é possível a supressão ou alteração da vegetação em áreas de preservação permanente nos casos previstos no Código Florestal e regulamentados pela Resolução no 369, de 28 de março de 2006.

O artigo $4^{\circ}$, "caput", do Código Florestal, prevê que a supressão total ou parcial de vegetação em áreas de preservação permanente poderá ser autorizada nos casos de utilidade pública ou de interesse social, devidamente caracterizados e motivados em procedimento administrativo próprio, quando inexistir alternativa técnica e locacional ao empreendimento proposto.

O artigo $2^{\circ}$, da Resolução CONAMA n ${ }^{\circ}$ 396, de 28 de março de 2006, impõe como condições para a alteração e supressão de vegetação em áreas de preservação permanente a existência de procedimento prévio, no qual se verifica o cumprimento da legislação federal, estadual e municipal, além do Plano Diretor, do Zoneamento EcológicoEconômico e Plano de Manejo de Unidades de Conservação, se existentes. 
A hipótese de utilidade pública, conforme o inciso I, do mesmo dispositivo citado, é caracterizada pelo seguinte:

a) atividades de segurança nacional e proteção sanitária;

b) obras essenciais de infra-estrutura destinadas aos serviços públicos de transporte, saneamento e energia;

c) as atividades de pesquisa e extração de substâncias minerais, outorgadas pela autoridade competente, exceto areia, argila, saibro e cascalho;

d) a implantação de área verdade pública em área urbana;

e) pesquisa arqueológica;

f) obras para implantação de instalações necessárias à captação e condução de água e de efluentes tratados;

g) implantação de instalações necessárias à captação e condução de água e de efluentes tratados para projetos privados de aqüicultura.

Quanto à hipótese de interesse social, inserem-se as seguintes atividades:

a) atividades imprescindíveis à proteção da integridade da vegetação nativa, tais como prevenção, combate e controle do fogo, controle da erosão, erradicação de invasoras e proteção de plantios com espécies nativas, de acordo com o estabelecido pelo órgão ambiental competente;

b) manejo agroflorestal, ambientalmente sustentável, praticado na pequena propriedade ou posse rural familiar, que não descaracterize a cobertura vegetal nativa, ou impeça sua recuperação, e não prejudique a função ecológica da área;

c) regularização fundiária sustentável de área urbana;

d) as atividades de pesquisa e extração de areia, argila, saibro e cascalho, outorgadas pela autoridade competente.

A Resolução CONAMA nº 396, de 28 de março de 2006, em seu artigo 11, dispõe sobre a intervenção ou supressão de vegetação eventual e de baixo impacto ambiental em área de preservação permanente, conceituando-a nas seguintes atividades:

a) abertura de pequenas vias de acesso interno e suas pontes e pontilhões, quando necessárias à travessia de um curso de água, ou à retirada de produtos oriundos das atividades de manejo agroflorestal sustentável praticado na pequena propriedade ou posse rural familiar;

b) implantação de instalações necessárias à captação e condução de água e efluentes tratados, desde que comprovada a outorga do direito de uso da água, quando couber;

c) implantação de corredor de acesso de pessoas e animais para obtenção de água; 
d) implantação de trilhas para desenvolvimento do ecoturismo;

e) construção de rampa de lançamento de barcos e pequeno ancoradouro;

f) construção de moradia de agricultores familiares, remanescentes de comunidades quilombolas e outras comunidades extrativistas e tradicionais em áreas rurais da região amazônica ou do Pantanal, onde o abastecimento de água se de pelo esforço próprio dos moradores;

g) construção e manutenção de cercas de divisa de propriedades;

h) pesquisa científica, desde que não interfira com as condições ecológicas da área, nem enseje qualquer tipo de exploração econômica direta, respeitados outros requisitos previstos na legislação aplicável;

i) coleta de produtos não madeireiros para fins de subsistência e produção de mudas, como sementes, castanhas e frutos, desde que eventual e respeitada a legislação específica a respeito do acesso a recursos genéticos;

j) plantio de espécies nativas produtoras de frutos, sementes, castanhas e outros produtos vegetais em áreas alteradas, plantadas junto ou de modo misto;

k) outras ações ou atividades similares, reconhecidas como eventual e de baixo impacto pelo conselho estadual de meio ambiente.

Segundo o artigo 11, $\S 2^{\circ}$, da citada Resolução, a intervenção ou supressão eventual e de baixo impacto ambiental deve respeitar o limite máximo de $5 \%$ (cinco por cento) da área da área de preservação permanente impactada localizada na posse ou propriedade.

Da exposição dos principais dispositivos das citadas resoluções, retira-se que houve um detalhamento do regime jurídico da área de preservação permanente disciplinada pelo Código Florestal a tal ponto que, para alguns doutrinadores, haveria excesso de poder regulamentar em prejuízo da proteção ambiental.

De certo modo, pensam desta forma Fernanda de Salles Cavedon, Ricardo Stanziola Vieira e Francelise Pantoja Diehl ${ }^{83}$ concluíram que “(...) as app's (...) vem sofrendo uma paulatina 'descaracterização jurídica', decorrente de alterações introduzidas no Código Florestal e que flexibilizaram o seu regime jurídico".

Entretanto, com respeito ao posicionamento dos doutrinadores, a leitura atenta dos principais pontos regulamentados pelas Resoluções no 302 e 303, de 20 de

${ }^{83}$ Op. cit. p. 35 
março de 2002 e n 396, de 28 de março de 2006, leva a crer que se trata de normatização extremamente técnica que justifica emanar de órgão da Administração Pública.

Além disso, deve ser sempre lembrado que a intervenção ou supressão de vegetação em área de preservação permanente "só se admitirá caso não haja alternativa técnica e locacional ao empreendimento proposto", daí o "caráter excepcional da medida",

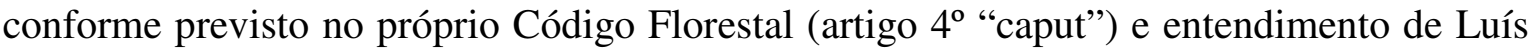
Paulo Sirvinskas ${ }^{84}$.

A redação atual do Código Florestal, que alberga o atual regime jurídico das áreas de preservação permanente, foi introduzida pela Medida Provisória $n^{\circ} 2.166$ 67/2001, não sem intensa discussão quanto à necessidade de lei em sentido estrito para autorizar a supressão total ou parcial de vegetação da área de preservação permanente, por ser ela espaço territorial especialmente protegido, conforme artigo $225, \S 1^{\circ}$, inciso III, da Constituição Federal, conforme já analisado.

No fundo, a discussão possuía um duplo aspecto, primeiro quanto a possibilidade ou não de medida provisória modificar o regime jurídico da área de preservação permanente, previsto no Código Florestal, nelas se permitindo a alteração ou supressão de vegetação e, segundo, quanto a exigência de lei específica em cada caso de supressão ou alteração de área de preservação permanente.

Erigiu-se, então, uma primeira corrente doutrinária, defensora da tese que, somente por meio de lei a referida supressão e alteração de vegetação em área de preservação permanente poderia ocorrer, em razão mesmo do artigo $225, \S 1^{\circ}$, inciso III, da Constituição Federal, adotada, por exemplo, por Paulo Affonso Leme Machado, Paulo de Bessa Antunes e José Eduardo Ramos Rodrigues.

Noutro quadrante, a segunda corrente doutrinária, defensora da tese da possibilidade de supressão e alteração de vegetação da área de preservação permanente por meio de ato administrativo, desde que nos casos determinados pelo Código Florestal e regulamentados também por atos administrativos normativos.

O debate a respeito deste conflito ocorreu no processo da ação direta de inconstitucionalidade registrada sob o $\mathrm{n}^{\mathrm{o}} 3.540-1$, movida pela Procuradoria Geral da República, e cujo Relator foi o Ministro Celso de Mello.

Tendo ocorrido em 01 de setembro de 2005, no julgamento da referida ação concluiu-se pela constitucionalidade e eficácia do artigo $4^{\circ}$ do Código Florestal,

\footnotetext{
${ }^{84}$ Manual de Direito Ambiental, São Paulo: Saraiva, 2008. p. 398
} 
conforme a redação da Medida Provisória $\mathrm{n}^{\circ}$ 2.166-67/2001, portanto, pela não necessidade de lei para autorizar a supressão de vegetação em APPs.

Segundo o Supremo Tribunal Federal, apesar da área de preservação permanente ser espécie de espaço territorial especialmente protegido, não se exige lei para autorizar a supressão total ou parcial de vegetação em seu âmbito, uma vez que o Código Florestal que as disciplina possui dispositivo que outorgou competência técnica a determinada entidade administrativa autorizar tal supressão.

Merece transcrição parte da ementa do acórdão, vazada nos seguintes termos:

O ART. $4^{\circ}$ DO CÓDIGO FLORESTAL E A MEDIDA PROVISÓRIA $\mathrm{N}^{\mathrm{o}}$ 2.166-67/2001: UM AVANÇO EXPRESSIVO NA TUTELA DE ÁREAS DE PRESERVAÇÃO PERMANENTE. - A Medida Provisória $\mathrm{n}^{\circ}$ 2.166-67, de 24/08/2001, na parte em que introduziu significativas alterações no art. $4^{\circ}$ do Código Florestal, longe de comprometer os valores constitucionais consagrados no art. 225 da Lei Fundamental, estabeleceu, ao contrário, mecanismos que permitem um real controle, pelo Estado, das atividades desenvolvidas no âmbito das áreas de preservação permanente, em ordem a impedir ações predatórias e lesivas ao patrimônio ambiental, cuja situação de maior vulnerabilidade reclama proteção mais intensa, agora propiciada, de modo adequado e compatível com o texto constitucional, pelo diploma normativo em questão. Somente a alteração e a supressão do regime jurídico pertinente aos espaços territoriais especialmente protegidos qualificam-se, por efeito da cláusula inscrita no art. $225, \S 1^{\circ}$, III, da Constituição, como matérias sujeitas ao princípio da reserva legal. É lícito ao Poder Público - qualquer que seja a dimensão institucional em que se posicione na estrutura federativa (União, Estados-membros, Distrito Federal e Municípios) - autorizar, licenciar ou permitir a execução de obras e/ou a realização de serviços no âmbito dos espaços territoriais especialmente protegidos, desde que, além de observadas as restrições, limitações e exigências abstratamente estabelecidas em lei, não resulte comprometida a integridade dos atributos que justificaram, quanto a tais territórios, a instituição de regime jurídico de proteção especial $\left(\mathrm{CF}\right.$, art. $225, \S^{\circ}$, III). (grifo nosso)

Deve-se notar que a discussão girou em torno da dúvida se o artigo 225 , $\S 1^{\circ}$, inciso III, da $\mathrm{CF}$, impõe a obrigação de lei em sentido estrito para a supressão e alteração da área de preservação permanente ou apenas da vegetação nela existente, tendo sido este último entendimento o adotado pelo Supremo Tribunal Federal para julgar 
improcedente a ação declaratória de inconstitucionalidade, tendo o Relator Ministro Celso de Mello ${ }^{85}$, em seu voto, anotado:

Vê-se, portanto, que somente a alteração e a supressão do regime jurídico pertinente aos Espaços Territoriais Especialmente Protegidos é que se qualificam, por efeito da cláusula inscrita no art. $225, \S 1^{\circ}$, III, da Constituição, como matérias sujeitas ao princípio da reserva de lei formal.

Quando se tratar, porém, de execução de obras ou de serviços a serem realizados em tais espaços territoriais, cumpre reconhecer que, observadas as restrições, limitações e exigências abstratamente estabelecidas em lei, tornar-se-á lícito ao Poder Público - qualquer que seja o nível em que se posicione na estrutura federativa (União, Estados-membros, Distrito Federal e Municípios) autorizar, licenciar ou permitir a realização de tais atividades no âmbito dos espaços territoriais especialmente protegidos, desde que não resulte comprometida a integridade dos atributos que justificaram, quanto a tais territórios, a instituição de um regime jurídico de proteção especial. (negrito do original)

O Ministro Cezar Peluso ${ }^{86}$, no mesmo julgamento, em seu voto trouxe interessante argumento quanto a possibilidade da disciplina do uso da área de preservação permanente ser feita por meio de ato administrativo: o controle da legalidade do mesmo, pois, para ele “(...) é mais fácil controlar a prática de um ato administrativo do que a edição de uma lei em sentido formal".

Diante do quadro supra, o melhor entendimento é o de considerar que o Código Florestal outorgou competência para o órgão administrativo ambiental autorizar a supressão total ou parcial de vegetação existente na área de preservação permanente e não da própria área de preservação permanente, tanto que tal órgão licenciador poderá exigir medidas de compensação do particular para tanto.

Este parece ser o entendimento que contempla o princípio da razoabilidade, na medida em que não seria razoável, a cada supressão ou alteração de vegetação de uma área de preservação permanente, o Poder Legislativo do ente federativo ser instado a manifestar-se e autorizá-la por meio de lei, até porque, por mais que o legislador possa ser assessorado tecnicamente em tais questões, jamais alcança a expertise dos órgãos especializados da Administração Pública que tratam unicamente de tal matéria.

\footnotetext{
${ }^{85}$ Ação Direta de Inconstitucionalidade $n^{0}$ 3.540-MC/DF, julgamento em 01/09/2005, publicação DJ 03/02/2006, p. 560-561

${ }^{86}$ Op. cit., p. 583
} 


\subsubsection{4 Área de preservação permanente: características e principais discussões:}

Podem-se resumir como principais características da área de preservação permanente o seguinte:

a) a generalidade, na medida em que são fixadas, com efeito, "erga omnes";

b) em regra, gratuidade, na medida em que não é cabível a indenização ao proprietário do imóvel pela sua instituição;

c) unilateralidade, na medida em que corporificam verdadeira imposição de vontade do Estado sobre a do particular, decorrente, portanto, do princípio da supremacia do interesse público;

d) são localizadas na zona rural;

e) são espécies de espaços territoriais especialmente protegidos;

f) são limitação a propriedade privada, com imposição de deveres positivos e negativos aos proprietários dos imóveis, como a de florestamento ou reflorestamento, entre outras medidas;

g) não são suscetíveis de implantação de empreendimentos exclusivamente econômicos, para geração de lucro individual;

h) podem ser públicas ou privadas, tanto que o Código Florestal não as diferencia em razão do domínio.

A área de preservação permanente visa a proteção de qualquer vegetação, florestal ou não, em decorrência da expressão "florestas e demais formas de vegetação natural" constante no "caput" dos artigos $2^{\circ}$ e $3^{\circ}$, do Código Florestal, sendo que, no passado, houve dúvida quanto ao termo "natural" referir-se ou não às florestas, o que acarretaria a interpretação quanto a inexistência de área de preservação permanente composta por florestas plantadas.

Tal interpretação, porém, mostrou-se irrazoável, na medida em que o artigo 12, do Código Florestal, prevê que somente em florestas plantadas não consideradas de preservação permanente há liberdade para extração de lenha, produtos florestais ou fabricação de carvão.

Também, o artigo 18, do Código Florestal, prevê que nas áreas privadas "onde seja necessário o florestamento ou o reflorestamento de preservação permanente, o Poder Público Federal poderá fazê-lo sem desapropriá-las, se não o fizer o proprietário" (grifo nosso). 
E, mais tardiamente, a introdução do conceito de áreas de preservação permanente no inciso II, do $\S 1^{\circ}$, do artigo $1^{\circ}$, do Código Florestal, veio a clarificar mais ainda tal discussão, pois nele se encontra a expressão "área (...) coberta ou não por vegetação nativa" (grifo nosso), ou seja, se não é nativa, pode ser plantada.

Diante das três regras comentadas confirma-se a possibilidade de florestas plantadas estarem inseridas nas áreas de preservação permanente, o que é confirmado por José Afonso da Silva ${ }^{87}$ :

\begin{abstract}
A interpretação correta é a de que tal adjetivo ("natural") só se refere à vegetação, não qualificando florestas. Por isso está no singular. (...) Assim há de ser pois, se se plantaram florestas no ambiente previsto nas alíneas do art. $2^{\circ}$, nada mais lógico que elas se subsumam ao regime jurídico ali qualificado.
\end{abstract}

Edis Milaré ${ }^{88}$ também defende esta idéia, marcando justamente o conteúdo do citado conceito legal como razão de assim entender.

Tais dispositivos também conduzem à outra conclusão, a possibilidade de tais áreas não estarem cobertas por formação florestal, podendo haver outro tipo de vegetação, como já referido, ou mesmo necessitando do florestamento ou reflorestamento.

Outro questionamento travado refere-se à composição das florestas da área de preservação permanente, se por indivíduos exóticos ou nativos, havendo posicionamentos quanto à necessidade de retirada dos primeiros, a fim de que se aumente o valor ecológico da área.

Sem dúvida, a retirada de indivíduos exóticos de uma floresta em área de preservação permanente pode contribuir para a melhora de seu valor ecológico, porém, tal extirpação deve ser realizada mediante compensação com outros indivíduos nativos, por meio de plano de manejo devidamente aprovado pelas autoridades administrativas competentes, sob pena da área ficar sem cobertura vegetal, portanto não cumprindo sua função ambiental.

Merece atenção também a discussão quanto à obrigação do Poder Público indenizar os proprietários de imóveis nos quais exista uma área de preservação permanente, dado eventual gravame sofrido na propriedade privada pela diminuição de seu uso.

\footnotetext{
${ }^{87}$ Op. cit. p. 164

${ }^{88}$ Direito do Ambiente. São Paulo: Editora Revista dos Tribunais, 2005. p. 360
} 
Apesar de não haver posicionamento pacífico a respeito de tal tema, entende-se que, quando se tratar de uma área de preservação permanente legal, a indenização é indevida, na medida em que ela se liga à localização das florestas e sua função ambiental, sendo, por isso mesmo, genérica, gratuita e unilateral, além de ser algo que antecede a propriedade do imóvel rural.

Tal espécie de área de preservação permanente antecede o próprio direito de propriedade do particular sobre o imóvel, sendo um gravame que sempre existiu, que é da natureza do bem e, portanto, não merece ser indenizado.

Antonio Herman de Vasconcellos e Benjamin ${ }^{89}$ bem fundamenta tal tese no fato de que a área de preservação permanente e a reserva florestal legal, no regime jurídico brasileiro, não "inviabilizam o exercício do direito de propriedade no restante do imóvel”.

Para ele, as áreas de preservação permanente legais e a reserva florestal legal seriam "limites internos" do domínio, caracterizando-o como uma "propriedade restrita", por isso: "Integram a essência do domínio, sendo com o título transmitidas. Não importam, per se, (...) 'em esvaziamento do conteúdo econômico do direito de propriedade"',

Mesmo entendimento é o de Luís Paulo Sirvinskas ${ }^{90}$, para quem:

(...) a instituição ou a supressão dessas áreas não ensejará qualquer tipo de indenização por parte do proprietário, pois as limitações legais são de ordem pública, as quais têm caráter de generalidade, gratuidade e unilateralidade, sendo conferido ao Poder Público através do poder de polícia administrativo. (grifo nosso)

Também entende desta forma Paulo Affonso Leme Machado ${ }^{91}$, para quem a área de preservação permanente legal é limitação administrativa, cujas características são a generalidade, a gratuidade, a unilateralidade e tratar-se de norma de ordem pública.

Por outro lado, na hipótese de uma área de preservação permanente administrativa, deverá ser indenizado o proprietário da área que sofreu tal limitação do direito de propriedade, decorrente de ato administrativo, assim também concluindo Luís Paulo Sirvinskas ${ }^{92}$ :

\footnotetext{
${ }^{89}$ Desapropriação, Reserva Florestal Legal e Áreas de Preservação Permanente, in Temas de Direito Ambiental e Urbanístico, São Paulo: Max Limonad, 1998, ano II, nº 03, p. 62 - 79

${ }^{90}$ Op. cit., p. 401

${ }^{91}$ Op. cit., p. 749

${ }^{92}$ Op. cit., p. $402-403$
} 
As áreas de preservação permanente criadas por ato administrativo são passíveis de indenização, pois ensejam uma limitação ao direito de propriedade. Parte da doutrina entende que, devido à impossibilidade da exploração normal da floresta, fica, assim, o Poder Público obrigado a indenizar o proprietário.

Antonio Herman de Vasconcellos e Benjamin ${ }^{93}$ considera as áreas de preservação permanente administrativas são de "ocorrência raríssima na vida prática" e que "conforme o caso, devem ser indenizadas" em razão do seguinte:

a) lhes faltar o traço da generalidade (afetar um ou poucos proprietários);

b) não beneficiarem, direta ou indiretamente, o proprietário; e

c) sua efetivação inviabilizar, por inteiro, a totalidade do único (hipótese raríssima) ou de todos os possíveis usos da propriedade, respeitado, evidentemente, o lapso prescricional, que corre da promulgação do ato administrativo de regência.

Denota-se, das razões invocadas pelo doutrinador, que são exatamente a contrariedade das características de uma limitação administrativa, sendo este também o entendimento de Paulo Affonso Leme Machado ${ }^{94}$.

A aplicação do regime jurídico da área de preservação permanente na zona urbana também tem gerado debates, em que pese o conteúdo do parágrafo único, do artigo $2^{\circ}$, do Código Florestal, que exclui as áreas urbanas de sua disciplina, submetendoas aos planos diretores e leis de uso do solo, "respeitados os princípios e limites" do mesmo Código, conforme anteriormente analisado.

Os planos diretores, por serem a lei básica de organização urbana dos Municípios, poderão fixar outros limites, desde que respeitados os limites mínimos do Código Florestal.

Os questionamentos colocados giram em torno de se saber se os planos diretores podem adotar limites maiores ou menores do que aqueles do Código Florestal.

A Lei $\mathrm{n}^{\mathrm{o}}$ 6.766, de 19 de dezembro de 1.979, que dispõe sobre o parcelamento do solo urbano, no seu artigo $2^{\circ}$, parágrafo único, inciso $\mathrm{V}$, proíbe o parcelamento do solo em "áreas de preservação ecológica".

\footnotetext{
${ }^{93}$ Loc. cit.

${ }^{94}$ Op. cit., p. 750
} 
Como a expressão "áreas de preservação ecológica”, constante na referida Lei, é mais ampla do que área de preservação permanente, é autorizado o entendimento de que numa área de preservação permanente não poderá haver parcelamento do solo, seguindo-se o regime jurídico do Código Florestal.

Especificamente quanto a limites, a citada Lei de Parcelamento do Solo Urbano, em seu artigo $4^{\circ}$, inciso III, com redação dada pela Lei $\mathrm{n}^{\circ} 10.932$, de 03 de agosto de 2004, prevê um mínimo de 15 (quinze) metros de faixa não edificável "ao longo de águas correntes e dormentes (...) salvo maiores exigências da legislação específica".

Portanto, o referido limite de área não edificável, apesar de ser menor do que o limite mínimo de uma área de preservação permanente ao longo de cursos d' água, que é de 30 (trinta) metros, não deverá ser adotado, pois a própria Lei de Parcelamento de Solo Urbano previu a obrigatoriedade de respeitar-se "maiores exigências da legislação específica".

Em relação a este assunto, Luís Carlos Silva de Moraes ${ }^{95}$ entende que a Lei de Parcelamento do Solo Urbano e o Código Florestal "estão ligadas por envio e reenvio nelas previstas (...) o que legitima a aplicação do Código Florestal na zona urbana, em especial as normas de APP" e completa: "E não é porque essas formações geológicas se dão na zona urbana que seu tratamento, em especial, as faixas de APP do art. $2^{\circ}$ do Código Florestal, possam ser alteradas.".

Quanto ao tema de supressão de área de preservação permanente em área urbana, o Código Florestal, no seu $\S 2^{\circ}$, do artigo $4^{\circ}$, estabelece a sua possibilidade, desde que submetida à autorização prévia do órgão ambiental competente, devendo o Município possuir conselho de meio ambiente com caráter deliberativo e plano diretor, mediante anuência prévia do órgão ambiental estadual competente fundamentada em parecer técnico.

$\mathrm{Ou}$ seja, é necessário licenciamento ambiental para tanto e que o Município possua uma estrutura mínima, um conselho que possibilite inclusive a participação social, conforme defende Paulo Affonso Leme Machado ${ }^{96}$.

Em relação ao limite de tal supressão de área de preservação permanente em área urbana, interpreta Luís Carlos Silva de Moraes ${ }^{97}$ que deverá sempre ser respeitado o limite de quinze metros previsto na Lei de Parcelamento do Solo Urbano:

\footnotetext{
${ }^{95}$ Código Florestal Comentado, São Paulo: Atlas, 2009. p. 97

${ }^{96}$ Op. cit. p. 741

${ }^{97}$ Loc..cit.
} 
Neste há previsão para a supressão de APP em zona urbana, por utilidade pública ou de interesse social. Pela combinação de ambos, chega-se à conclusão de que a supressão não poderá ser total, havendo sempre o respeito à faixa não edificável de 15 metros de cada lado do corpo d'água.

Ainda a confirmar a aplicação do regime jurídico da área de preservação permanente em áreas urbanas, tem-se que a Lei $n^{\circ} 10.931$, de 02 de agosto de 2004, que dispõe sobre o patrimônio de afetação de incorporações imobiliárias e outros assuntos afetos a tal atividade, teve seu artigo 64 vetado pelo Presidente da República em razão da previsão original de não manutenção dos limites de área de preservação permanente do Código Florestal para áreas urbanas e de expansão urbana.

A redação do artigo 64, do Projeto de Lei no 47, de 2004 (nº 2.109/99 na Câmara dos Deputados) era a seguinte: “Artigo 64 - Na produção imobiliária, seja por incorporação ou parcelamento do solo, em áreas urbanas e de expansão urbana, não se

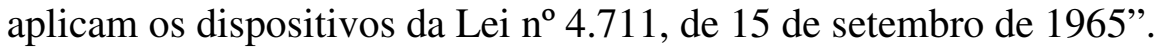

Consta nas razões de veto, veiculadas na Mensagem $\mathrm{n}^{\circ} 461$, de 02 de agosto de 2004, como um dos principais argumentos, o fato da área de preservação permanente ser espécie de espaço territorial especialmente protegido pelo poder público, conforme artigo 225, $\S 1^{\circ}$, inciso III, da Constituição Federal, devendo ser submetido à disciplina do Código Florestal.

Portanto, mais uma vez confirma-se a tese que também para as áreas urbanas deve ser aplicado o regime jurídico de área de preservação permanente previsto no Código Florestal, em especial aquelas do artigo $2^{\circ}$, denominadas áreas de preservação permanente legais.

A função ambiental desempenhada por uma área de preservação permanente na zona urbana pode ser sensivelmente diversa daquela localizada na zona rural, uma vez que, principalmente em grandes centros urbanos, os ecossistemas estão seriamente comprometidos.

Noutro quadrante, a área de preservação permanente em zona urbana pode desempenhar outras funções ambientais relevantes, tais como a dispersão da poluição, amenização da temperatura em seu entorno, melhoria da paisagem, aumento da umidade relativa do ar, absorção de ruído e mesmo a proteção de nascentes e cursos d'água, tal como a área de preservação permanente em zona rural, o que também justifica a adoção do 
regime jurídico do Código Florestal às áreas urbanas, conforme entendimento de José Gustavo de Oliveira Franco ${ }^{98}$.

Outro debate a respeito das áreas de preservação permanentes legais refere-se a obrigatoriedade de sua recuperação, tanto pelo poder público, quanto pelo particular, em razão do que prevê o artigo 18, do Código Florestal, nestes termos:

Artigo 18 - Nas terras de propriedade privada, onde seja necessário o florestamento ou o reflorestamento de preservação permanente, o Poder Público Federal poderá fazê-lo sem desapropriá-las, se não o fizer o proprietário.

$\S 1^{\circ}$ Se tais áreas estiverem sendo utilizadas com culturas, de seu valor deverá ser indenizado o proprietário.

$\S 2^{\circ}$ As áreas assim utilizadas pelo Poder Público Federal ficam isentas de tributação.

Conforme exposto neste trabalho, as áreas de preservação permanente legais não são meras limitações administrativas, mas delimitação do próprio direito de propriedade prevista na Lei Florestal, de tal forma que caracterizam a função sócio ambiental da propriedade.

Deste modo, mesmo quando a área de preservação permanente não possuir vegetação, estando sob exploração de alguém, deverá ser recuperada, até porque tal exploração desrespeita frontalmente o Código Florestal e o caráter de preservação de tal área.

O fato de não estar coberta por vegetação, conforme prevê o próprio conceito constante no artigo $2^{\circ}$, inciso II, $\S 2^{\circ}$, do Código Florestal, não lhe retira a natureza de área de preservação permanente.

O Código Florestal impõe, portanto, um dever de conservação e recuperação de tal área de preservação permanente, o que também é confirmado pela Lei $\mathrm{n}^{\circ}$ 9.605, de 13 de fevereiro de 1998 (Lei dos Crimes Ambientais), que, em seus artigos 38 e 48 capitula como crimes as condutas de "destruir ou danificar florestas de preservação permanente, mesmo que em formação, ou utiliza-la com infringência das normas de proteção" e "impedir ou dificultar a regeneração natural de florestas e demais formas de vegetação".

$\mathrm{O}$ artigo $18, \S 1^{\circ}$, do retro transcrito, também recebe críticas de alguns doutrinadores por prever a indenização aos proprietários do imóvel pela cultura

\footnotetext{
${ }^{98}$ Direito Ambiental - Matas Ciliares, Conteúdo Jurídico e Biodiversidade, Curitiba: Juruá, 2009. p. 101
} 
eventualmente existente em área de preservação permanente que venha a ser recuperada, uma vez que em tal área jamais deveria ter sido implantada uma cultura.

Neste sentido é a lição de Ângela Aparecida Napolitano e Ângela Issa Haonat ${ }^{99}$ :

\begin{abstract}
A doutrina tem defendido que a obrigação de reconstituir a vegetação natural nas áreas de preservação permanente e reserva legal, possui caráter real - propter rem. No entanto, essa conclusão corre o risco de encontrar obstáculo no privilégio injustificável do art. 18 do Código Florestal, o qual prevê a indenização do valor das culturas efetuadas em terras de preservação permanente cujo reflorestamento seja efetuado compulsoriamente pelo poder público, se não o fizer o proprietário. (grifo nosso)
\end{abstract}

Ainda na temática da recuperação de áreas de preservação permanente, Giuliano Deboni ${ }^{100}$, citando Paulo Affonso Leme Machado, entende que "as florestas do art. $2^{\circ}$ do Código Florestal são imperativas, enquanto as do art. $3^{\circ}$ dependem de motivação, mediante a análise da conveniência e da oportunidade de florestar e reflorestar.”.

Quanto à demarcação e averbação da área de preservação permanente na matrícula do imóvel, junto ao Registro de Imóveis, não há previsão na legislação federal de forma semelhante ao que ocorre com a reserva florestal legal, sendo que há doutrinadores, como Paulo Affonso Leme Machado ${ }^{101}$, que defendem tal demarcação em razão de possuir verdadeiro "efeito pedagógico, pois os proprietários privados se autoconscientizam da função social de seus imóveis, e no caso das áreas urbanas educa-se a população e comprova-se a boa governança ambiental".

Sendo estas as principais questões referentes à área de preservação permanente, adentra-se na reserva florestal legal, outro instrumento de proteção da flora previsto no Código Florestal.

\title{
1.7.4 Reserva florestal legal:
}

No artigo $2^{\circ}$, inciso III, do Código Florestal, com redação dada pela Medida Provisória n ${ }^{\circ}$ 2.166-67, de 24 de agosto de 2001, encontra-se um conceito para a reserva legal como "área no interior de uma propriedade ou posse rural, excetuada a de

\footnotetext{
${ }^{99}$ Op. cit., p. 134

${ }^{100}$ Florestas: Competência para Legislar e Fiscalizar, Revista Magister de Direito Ambiental e Urbanístico, ano III, n. 14, out.-nov./2007, p. 81-101

${ }^{101}$ Op. cit., p. 742
} 
preservação permanente, necessária ao uso sustentável dos recursos naturais, à conservação e reabilitação dos processos ecológicos, à conservação da biodiversidade e ao abrigo e proteção de fauna e flora nativas".

Conforme bem lecionado por Paulo Affonso Leme Machado ${ }^{102}$, o termo "reserva legal" merece ser substituído por "reserva legal florestal", porque a reserva biológica, prevista na Lei $\mathrm{n}^{\text {o }}$ 9.985/2000 também seria uma espécie de reserva legal, podendo haver, assim, confusão entre o regime jurídico designado pela expressão "reserva legal" e os diversos objetos específicos desse regime.

Também, a adoção da expressão reserva florestal legal é apropriada para que não haja confusão com o princípio da reserva legal previsto no artigo $5^{\circ}$, da Constituição Federal.

Mesma opinião é a de Luis Carlos Silva de Moraes ${ }^{103}$ : "Corriqueiramente denominada 'reserva legal', deve-se acostumar a nominá-la 'reserva florestal legal', como distinção necessária a instituto jurídico superior que é o princípio constitucional da 'reserva legal' (fazer ou deixar de fazer senão em virtude de lei)".

A reserva florestal legal corresponde sempre a um percentual da propriedade, que difere a depender das regiões do país e dos tipos de vegetação, sendo que os percentuais estão previstos no artigo 16, incisos I a IV, do Código Florestal, e são os seguintes:

a) oitenta por cento, na propriedade rural situada em área de floresta localizada na Amazônia Legal;

b) trinta e cinco por cento, na propriedade rural situada em área de cerrado localizada na Amazônia Legal, sendo no mínimo vinte por cento na propriedade e quinze por cento na forma de compensação em outra área, desde que esteja localizada na mesma microbacia, e seja averbada na matrícula do imóvel;

c) vinte por cento, na propriedade rural situada em área de floresta ou outras formas de vegetação nativa localizada nas demais regiões do país;

d) vinte por cento, na propriedade rural situada em área de campos gerais localizada em qualquer região do país.

O conceito de Amazônia Legal está previsto no inciso VI, do artigo 1], do Código Florestal, como os Estados do Acre, Pará, Amazonas, Roraima, Rondônia, Amapá e Mato Grosso e as regiões situadas ao norte do paralelo $13^{\circ} \mathrm{S}$ (treze graus sul), dos Estados

${ }^{102}$ Op. cit., p. 755

${ }^{103}$ Código Florestal Comentado, São Paulo: Atlas, 2009. p. 231 
de Tocantins e Goiás, e ao oeste do meridiano de $44^{\circ} \mathrm{W}$ (quarenta e quatro graus oeste), do Estado do Maranhão.

Paulo Affonso Leme Machado ${ }^{104}$ esclarece que se trata de verdadeiro "regime jurídico florestal", cujo objetivo seria a formação de um "estoque vegetal para conservar a biodiversidade", podendo ser classificados quatro tipos de reserva florestal legal, em razão dos ecossistemas em que se localizam, a saber:

a) na Amazônia Legal;

b) na área de cerrado;

c) na área de campos gerais e

d) nas demais áreas do país.

Segundo o artigo 16, "caput" do Código Florestal, é permitida a supressão de florestas ou outras formas de vegetação nativa, no interior de uma propriedade, mantidas a área de preservação permanente, áreas sujeitas ao regime de utilização limitada, áreas objeto de legislação específica e a reserva legal naqueles percentuais.

Luís Paulo Sirvinskas ${ }^{105}$ esclarece que, "delimitada a reserva legal, a exploração da área restante passa a ser permitida, mediante autorização e fiscalização do IBAMA, sob o regime de utilização limitada.”.

Portanto, a reserva florestal legal é uma restrição legal que recai sobre a propriedade, sendo que o $\$ 2^{\circ}$, do artigo 16, do Código Florestal, reiterando os termos do mencionado "caput", proíbe expressamente a supressão de vegetação da área de preservação permanente e permite o uso sob o regime de manejo florestal sustentável, de acordo com princípios e critérios técnicos e científicos regulamentados em legislação.

Em relação ao corte raso de espécies vegetais na reserva florestal legal, a antiga redação do artigo 44, do Código Florestal, o proibia expressamente, sendo que, com a alteração do texto promovida pela Medida Provisória n ${ }^{\circ} 2.166-67$, de 24 de agosto de 2001, tal prática amolda-se a situação de ilícito administrativo disciplinado pelo artigo 51, do Decreto $\mathrm{n}^{\circ}$ 6.514, de 22 de julho de 2008 (Regulamento do Processo Administrativo de Infrações Administrativas ao Meio Ambiente).

Quanto à sua localização na propriedade, dispõe o $\$ 4^{\circ}$, do artigo 16 , do Código Florestal que deve ser aprovada pelo órgão ambiental estadual competente ou, mediante convênio, pelo órgão ambiental municipal ou outra instituição habilitada,

${ }^{104}$ Op. cit., p. 755

${ }^{105}$ Op. cit. p. 404 
devendo ser considerados no processo de aprovação a função social da propriedade e os seguintes critérios e instrumentos, quando houver:

a) plano de bacia hidrográfica;

b) plano diretor municipal;

c) o Zoneamento Ecológico Econômico;

d) outras categorias de zoneamento ambiental;

e) a proximidade com outra reserva florestal legal, área de preservação permanente, unidade de conservação ou outra área legalmente protegida.

Desta regra, denota-se que a demarcação da área de reserva florestal legal é procedimento técnico que se interelaciona com outros instrumentos de proteção ambiental, constituindo-se em verdadeiro licenciamento ambiental, conforme também realçado por Paulo Affonso Leme Machado ${ }^{106}$ :

A legislação da Reserva Legal Florestal passou a exigir que o proprietário rural enfrente o procedimento do licenciamento ambiental (ainda que sob outros nomes aprovação ou aprovação prévia) pelo menos por duas vezes. Isto se não lhe for imposto submeter o plano de manejo para aprovação todos os anos.

Considerando-se o que for indicado em Zoneamento Ecológico Econômico e no Zoneamento Agrícola, poderá o Poder Executivo, ouvidos o Conselho Nacional do Meio Ambiente - CONAMA, do Ministério do Meio Ambiente, o Ministério da Agricultura, Pecuária e Abastecimento, autorizar a redução ou ampliação da reserva florestal legal, em conformidade com o que prevê o artigo $16, \S 5^{\circ}$, do Código Florestal.

A redução do percentual referente à reserva florestal legal, para fins de recomposição, na Amazônia Legal, é de até cinqüenta por cento da propriedade, excluindose a área de preservação permanente, os ecótonos (regiões de transição de biomas diferentes), os sítios e ecossistemas especialmente protegidos, os locais de expressiva biodiversidade e os corredores ecológicos (artigo 16, inciso I, §5º do Código Florestal).

A ampliação da área de reserva florestal legal, por outro lado, em até cinqüenta por cento dos índices previstos no Código Florestal, é permitida em todo o território nacional, conforme dispõe o artigo 16, inciso II, §5 , do Código Florestal.

Para Paulo Affonso Leme Machado ${ }^{107}$, a Medida Provisória no 2.166-67, de 24 de agosto de 2001, que instituiu a possibilidade de redução e ampliação da reserva

\footnotetext{
${ }^{106}$ Op. cit. , p. 759
}

${ }^{107}$ Op. cit., p. 764 
florestal legal, modificou profundamente o regime jurídico anterior, deixando que o "tamanho da Reserva ficasse na dependência do ato do Governo", vislumbrando, nisso, a instituição de um "sistema de desigualdade, que pode ferir a generalidade da limitação ao direito de propriedade, garantidora da gratuidade da própria limitação".

$\mathrm{O}$ artigo $16, \S 6^{\circ}$, do Código Florestal permite que seja computada na área de reserva florestal legal a vegetação nativa existente em área de preservação permanente, desde que não implique em conversão de novas áreas para uso alternativo do solo e quando a soma da vegetação nativa em área de preservação permanente e reserva florestal legal exceder a:

a) oitenta por cento da propriedade rural localizada na Amazônia Legal;

b) cinqüenta por cento da propriedade rural localizada nas demais áreas do país;

c) vinte e cinco por cento da pequena propriedade rural ou posse familiar, explorada mediante trabalho pessoal do proprietário ou posseiro e de sua família, admitida ajuda eventual de terceiro e cuja renda bruta seja proveniente, no mínimo, em oitenta por cento, de atividade agroflorestal ou de extrativismo.

Os limites de área da pequena propriedade rural ou posse familiar são diferentes, a depender da região do país, e estão previstos no artigo $1^{\circ}, \S 2^{\circ}$, alíneas a) e b), do Código Florestal.

A área de reserva florestal legal deve sofrer averbação à margem da inscrição de matrícula do imóvel, no registro de imóveis competente, sendo vedada a alteração de sua destinação, nos casos de transmissão, a qualquer título, de desmembramento ou de retificação de área, sendo gratuita no caso da pequena propriedade ou posse rural familiar, conforme artigo $16, \S \S 8^{\circ}$ e $9^{\circ}$, do Código Florestal.

Ou seja, a destinação da área para a reserva florestal legal é inalterável, mesmo nos casos de transmissão do imóvel, por modo originário ou derivado, fato este bem explicado por Paulo Affonso Leme Machado: "Nos casos de transmissão por compra e venda como, também, por acessão, usucapião e pelo direito hereditário, a área de Reserva, a partir da promulgação da Lei 7.803/1989, continua com os novos proprietários numa cadeia infinita." (grifo nosso).

Isto, em verdade, comprova o caráter de obrigação "propter rem”, ou seja, ligada à coisa e não à pessoa do proprietário, sendo que um novo adquirente do imóvel rural será responsável pela existência da reserva florestal legal. 
Paulo Affonso Leme Machado ${ }^{108}$ entende que qualquer pessoa pode promover o registro de tal averbação da reserva florestal legal, independentemente de ser ou não o proprietário do imóvel rural, inclusive o Ministério Público e associações.

Ana Maria de Oliveira Nusdeo ${ }^{109}$ entende que a obrigação de averbação da reserva legal junto à matrícula do imóvel, no registro de imóveis competente: “(...) é uma regra interessante, pois cumpre o objetivo de publicidade que é característica dos registros públicos em geral, mas acrescenta a esse o objetivo da destinação da perenidade da área pelo atual e por futuros proprietários" (grifo nosso).

O dever de manutenção da reserva florestal legal independe de sua averbação na matrícula do imóvel rural, perante o registro de imóveis competente, porém, não é incomum a legislação ambiental exigir sua comprovação (da averbação) nos processos de licenciamento ambiental para outras atividades na propriedade, como, por exemplo, a Portaria IBAMA n 9, de 23 de janeiro de 2002, que estabelece o Roteiro e Especificações Técnicas para o Licenciamento Ambiental em Propriedade Rural.

Há entendimentos doutrinários até no sentido da possibilidade de ajuizamento de ações civis públicas em face de tabeliães, para que se abstenham de praticar atos registrários ou notariais em matrículas de imóveis rurais sujeitos à da averbação da RFL, tal como defende Alexandre de Matos Guedes ${ }^{110}$.

Também é permitida a instituição de reserva florestal legal em regime de condomínio, entre mais de uma propriedade, desde que respeitado o percentual legal em cada imóvel, mediante aprovação do órgão ambiental estadual competente e as averbações referentes a todos os imóveis envolvidos (artigo 16, § 11, do Código Florestal).

No loteamento de propriedade rural, a área destinada a completar os limites percentuais da reserva florestal legal poderá ser agrupada numa só porção em condomínio entre os adquirentes, conforme artigo 17, do Código Florestal.

Conforme prevê o artigo $16, \S 3^{\circ}$, do Código Florestal, em pequena propriedade ou posse rural familiar, para o cumprimento da manutenção ou compensação da área de reserva florestal legal, podem ser computados os plantios de árvores frutíferas

\footnotetext{
108 Op. cit., p. 761

109 Servidão Florestal para fins de compensação de Reserva Legal: instrumento de incentivo à proteção florestal? in Revista Brasileira de Direito Ambiental, São Paulo: Editora Fiúza, v. 48, 2007, p. 35

${ }^{110}$ A concretização da Reserva Legal via de Ação Civil Pública proposta em face de Tabeliães de Registro de Imóveis, in Anais do $3^{\circ}$ Congresso Internacional de Direito Ambiental, 30 de maio a 02 de junho de 1999: a proteção jurídica das florestas tropicais, BENJAMIN, Antonio Herman de Vasconcellos e. São Paulo: IMESP, 1999. p. 25
} 
ornamentais ou industriais, compostos por espécies exóticas, cultivadas em sistema intercalar ou em consórcio com espécies nativas.

Assim, em regra a reserva florestal legal pode ser composta por florestas nativas, primitivas ou regeneradas e, excepcionalmente, no caso da pequena propriedade ou posse rural familiar, ser computada espécie exótica, desde que cultivadas naquele sistema intercalar ou consorciado.

Neste quadrante, também se incluem os questionamentos se a reserva florestal legal deve ser computada sobre toda a área do imóvel, incluindo-se nela a área de área de preservação permanente, ou se somente sobre a área em que não se encontra a área de preservação permanente, ou seja, excluindo-a.

Giuliano Deboni ${ }^{111}$ indica que no Estado do Rio Grande do Sul, por exemplo, os órgãos ambientais elegeram a primeira forma de cálculo, computando-se a área total do imóvel, sem desconto da área de preservação permanente, para incidir o percentual legal da reserva florestal legal.

Contudo, dada a natureza e finalidade praticamente idênticas da reserva florestal legal com a área de preservação permanente, principalmente legal, muitos doutrinadores entendem que o cômputo da área incluindo esta última seria verdadeiro "bis in idem", o que é defendido por Ricardo Domingos Rinhel ${ }^{112}$ :

Não é lógico exigir-se, no caso em tela, que o percentual da reserva legal incida sobre a terra nua e a área de preservação permanente, uma vez que esta tem finalidade idêntica à da reserva legal. O razoável é que se institua a reserva legal sobre a terra nua, ou melhor, sobre toda a área do imóvel, excluída a área de preservação permanente.

No artigo 44, do Código Florestal, é imposto o dever do proprietário de imóvel rural recompor sua reserva florestal legal caso a "área de floresta nativa, natural, primitiva ou regenerada ou outra forma de vegetação nativa” possuir extensão inferior aos percentuais previstos, adotando as seguintes medidas, isoladas ou conjuntamente:

a) plantio, a cada três anos, de no mínimo 1/10 (um dez avos) da área total necessária à sua complementação, com espécies nativas, de acordo com critérios estabelecidos pelo órgão ambiental estadual competente;

\footnotetext{
111 Loc. cit.

112 Direito Ambiental: incidência do percentual da área de preservação permanente na reserva florestal legal. In Revista de Direito Ambiental, n. 40, out.-dez./2005. p. 163-185
} 
b) conduzir a regeneração natural da reserva florestal legal, com autorização do órgão técnico, podendo tal área permanecer isolada ( $\$ 3^{\circ}$, do artigo 44, do Código Florestal);

c) compensar a reserva florestal legal por outra área equivalente em importância ecológica e extensão, desde que pertença ao mesmo ecossistema e esteja localizada na mesma microbacia, conforme critérios previstos em regulamento.

No artigo 99, da Lei nº 8.171, de 17 de janeiro de 1991 (Lei da Política Agrícola Nacional), foi previsto que, a partir do ano seguinte de sua promulgação, o proprietário rural é obrigado a recompor a reserva florestal legal em sua propriedade mediante o plantio, em cada ano, de pelo menos um trinta avos da área total para complementar a referida reserva.

A principal diferença da reserva florestal legal em relação à área de preservação permanente é fato daquela ser aplicável somente à propriedade privada, enquanto esta última pode ser aplicada tanto para a propriedade privada, quanto pública, o que é corroborado por Luis Paulo Sirvinskas ${ }^{113}$.

Todavia, reitera-se, quanto à natureza jurídica a reserva florestal legal assemelha-se à área de preservação permanente legal, do artigo $2^{\circ}$, do Código Florestal, por isso não é passível de ser indenizada ao proprietário da área, até porque o seu uso não é totalmente interditado, podendo ocorrer o manejo florestal sustentável antecedido de licenciamento ambiental.

Neste particular, a explicação de Teresa Cristina de Deus ${ }^{114}$ :

Uma vez que a instituição desse tipo de reserva nada mais é do que mera restrição ao uso da propriedade, não há que se falar em nenhum direito à indenização, nem mesmo compensação ao proprietário da área onde a mesma está inserida.

Desta exposição podem ser sintetizadas as principais características da reserva florestal legal, conforme o magistério de Paulo Affonso Leme Machado ${ }^{115}$ e Luis Paulo Sirvinskas:

a) inalterabilidade de sua destinação, pois, uma vez constituída a reserva florestal legal é perpétua e mantida mesmo quando houver transmissão do imóvel rural, mesmo ocorrendo desmembramento ou retificação de sua área;

\footnotetext{
${ }^{113}$ Op. cit., p. 404

${ }^{114}$ Tutela da Flora em face do Direito Ambiental Brasileiro, São Paulo: Juarez de Oliveira, 2003, p. 128

${ }^{115}$ Reserva Legal Florestal, in Revista de Direitos Difusos, São Paulo: ADCOAS, ano VI, vol. 31, maio - jun. 2005, p. $11-13$
} 
b) restrição quanto ao seu uso, com a proibição ao corte raso e permissão apenas ao manejo florestal sustentável, mediante prévia autorização do órgão competente e licenciamento ambiental;

c) gratuidade na sua constituição, na medida em que não é indenizada ao proprietário do imóvel rural pelo poder público e não acarreta custo à pequena propriedade ou posse rural familiar;

d) obrigatoriedade de averbação na matrícula do imóvel rural, perante o registro de imóveis competente;

e) necessidade de medição, demarcação e delimitação por meio de procedimento tramitado diante do órgão ambiental competente;

f) isenção tributária.

Com posicionamento peculiar, Luís Carlos Silva de Moraes defende que o regime jurídico da reserva florestal legal do Código Florestal não foi recepcionado pela atual ordem constitucional, invocando como principais argumentos ao seu modo de pensar: a) o regime jurídico da reserva florestal legal é restrito e incompatível com o novo sistema normativo de proteção integral do ecossistema e bioma, cuja base encontra-se no artigo 225, da Constituição Federal;

b) o regime jurídico da reserva florestal legal, antes mesmo da nova ordem constitucional, foi substituído por outro regime jurídico de proteção plena;

c) sob o ponto de vista fático e técnico, a reserva florestal legal pode causar desequilíbrio ambiental.

Conforme sua teoria, o artigo 225, da Constituição Federal, instituiu um sistema de proteção integral do ecossistema que é incompatível com a lógica do regime jurídico da reserva florestal legal do Código Florestal, pois aquele seria baseado em três premissas lógicas: a individualização do ecossistema que será objeto de proteção, a identificação objetiva da área em que o ecossistema se situa e as medidas biológicas e jurídicas necessárias para se garantir a efetividade do comando constitucional, caso a caso.

Luis Carlos Silva de Moraes $^{116}$ defende que o Sistema Nacional das Unidades de Conservação, instituído pela Lei $\mathrm{n}^{\circ}$ 9.985, de 18 de julho de 2000, atende plenamente o sistema de preservação integral previsto no artigo 225, da Constituição Federal, pois se baseia no Zoneamento Ecológico Econômico prévio, como condição para

${ }^{116}$ Op. cit., p. 283 
a criação das unidades de conservação de proteção integral ou de uso sustentável, tendo substituído o regime jurídico da reserva florestal legal previsto no Código Florestal.

Apesar das razões invocadas pelo doutrinador, a reserva florestal legal contempla instrumentos de proteção do ecossistema, tanto que, quanto a sua localização no imóvel rural, conforme artigo 16, $\S 4^{\circ}$, do Código Florestal, devem ser contemplados critérios e instrumentos tais como o plano da bacia hidrográfica, o plano diretor municipal, o Zoneamento Ecológico Econômico, outras categorias de zoneamento ambiental e a proximidade com outra reserva florestal legal, área de preservação permanente, unidade de conservação ou qualquer outra área legalmente protegida.

Denota-se, portanto, que o regime jurídico da reserva florestal legal é consentâneo com o sistema de preservação integral de ecossistemas e biomas disciplinado no artigo 225, da Constituição Federal, conforme tese do citado doutrinador.

Em relação à competência legislativa sobre normas aplicáveis a reserva florestal legal pelos demais entes federativos além da União, é entendimento de Giuliano Deboni ${ }^{117}$ que dever ser exercida "apenas para torná-las mais severas, mas não abrandá-las, sob pena de afastar-se do objeto principal: a preservação do meio ambiente.”.

De tudo o que se enfrentou, conclui-se pela pacífica convivência entre as regras do Código Florestal, aplicáveis à área de preservação permanente e à reserva floresta legal, com aquelas aplicáveis às unidades de conservação e aos biomas protegidos, temas estes desnudados nos próximos tópicos.

\subsubsection{Servidão florestal e cota de reserva florestal:}

No artigo 44-A, do Código Florestal, é conferida ao proprietário rural a possibilidade de instituir servidão florestal mediante a qual voluntariamente renuncia, em caráter permanente ou temporário, o direito de supressão ou exploração de vegetação nativa, localizada fora da reserva florestal legal e da área de preservação permanente.

Este é mais um instrumento de proteção florestal, além da reserva florestal legal e da área de preservação permanente, mas com caráter facultativo e que incide somente sobre imóveis do domínio privado.

A servidão florestal pode ser adotada nos casos em que, por exemplo, em determinada propriedade rural a reserva florestal legal não estiver totalmente reconstituída,

${ }^{117}$ Loc. cit. 
podendo haver uma compensação por meio da instituição de servidão florestal sobre áreas de vegetação já reconstituída ou intocada.

No $\S 1^{\circ}$, do citado dispositivo, prescreve-se que tal limitação ao uso da vegetação da área sob regime de servidão florestal deve ser, no mínimo, a mesma estabelecida para a reserva florestal legal.

Assim, dependendo das características da propriedade, como o tipo de vegetação ou localização no país, a reserva florestal legal terá determinada extensão e uso, sendo este último, inclusive, regulamentado por plano de manejo previamente aprovado pela autoridade ambiental competente, o mesmo sendo aplicado à servidão florestal.

E, para que se cumpra o princípio da publicidade, o artigo 44-A, $\S 2^{\circ}$, do Código Florestal, impõe o dever de averbação da servidão florestal à margem da inscrição de matrícula do imóvel, no registro de imóveis, após anuência do órgão ambiental estadual, sendo vedada, durante o prazo de sua vigência, a alteração da destinação da área, nos casos de transmissão a qualquer título, de desmembramento ou de retificação dos limites de propriedade.

Então, é visível que o regime jurídico ao qual está submetida a servidão florestal é bastante parecido com o da reserva florestal legal, já que, para a área de preservação permanente, o Código Florestal não impõe, ao menos explicitamente, tal obrigação de averbação da área à margem da matrícula do imóvel rural, no registro de imóveis.

Sendo a servidão florestal uma autolimitação do uso do imóvel rural, instituída pelo próprio proprietário, incabível a indenização pelo poder público em razão da sua constituição.

A lei é silente quanto à possibilidade de instituição de servidão florestal sobre a posse rural familiar, não se vislumbrando óbice a sua ocorrência, podendo ser adotada a regra do artigo $16, \S 10$, do Código Florestal, por analogia.

Esse dispositivo, aplicado à instituição da reserva florestal legal em posse, prevê a necessidade de estabelecimento de um termo de ajustamento de conduta entre o possuidor e o órgão ambiental ou federal competente, com força de título executivo e contendo, no mínimo, a localização da citada reserva, as suas características ecológicas básicas e a proibição de supressão de sua vegetação, aplicando-se, no que couber, as mesmas disposições do Código Florestal para propriedade rural.

A cota de reserva florestal, instituída pelo artigo 44-B, do Código Florestal, consiste num título representativo de vegetação nativa sob regime de servidão 
florestal, de reserva particular do patrimônio natural ou reserva florestal legal instituída voluntariamente sobre vegetação que exceder os percentuais estabelecidos no art. 16, do Código Florestal.

Anote-se que a citada reserva particular do patrimônio natural é uma espécie de unidade de uso sustentável disciplinada na Lei nº 9.985, de 18 de julho de 2000 (Lei do Sistema Nacional das Unidades de Conservação).

A emissão de um título representativo das parcelas protegidas de vegetação do imóvel rural, sobre as quais o proprietário não exerce todos os atributos da propriedade, visa estimular um determinado comportamento conservacionista e preservacionista da flora, podendo também ser utilizado com o mesmo objetivo da servidão florestal, para compensar áreas faltantes para a recomposição de reserva florestal legal.

O aludido dispositivo do Código Florestal ainda não foi regulamentado, tendo havido apenas a apresentação de um projeto de lei para tal fim, pelo Deputado Federal Luciano Castro, em 12 de setembro de 2005, registrado sob o número PL$5876 / 2005$.

Segundo o citado projeto de lei, a cota de reserva florestal seria emitida pelo órgão federal executor do Sistema Nacional do Meio Ambiente - SISNAMA, que, atualmente, é a autarquia federal Instituto Brasileiro do Meio Ambiente e dos Recursos Naturais Renováveis - IBAMA.

Também, tal certificado de reserva florestal sofreria averbação na matrícula do imóvel rural e poderia ser transferido, de forma onerosa ou gratuita, entre pessoas físicas ou jurídicas, estas últimas de direito público ou privado, mediante termo assinado pelo titular e pelo adquirente do título.

A finalidade do certificado de reserva florestal, conforme o artigo $5^{\circ}, \S 2^{\circ}$, do projeto de lei, seria a compensação da reserva florestal legal e a proteção de áreas de interesse ambiental, sendo que, para a compensação, exigir-se-ia que o imóvel rural se situasse no mesmo Estado e no mesmo bioma da área à qual o título estivesse vinculado.

O proprietário do imóvel rural, ainda, deveria manter a área vinculada ao certificado de reserva florestal nas mesmas condições de preservação da vegetação nativa da área que deu origem ao título, sendo que a transmissão do imóvel, a que título fosse, não eliminaria e nem alteraria o vínculo de área contida no imóvel ao certificado.

Por fim, as hipóteses de cancelamento do título poderiam ser a solicitação do proprietário rural, caso viesse a desistir de manter a área sob servidão florestal, a não manutenção da área de reserva florestal legal excedente dos limites legais mínimos, o 
término do prazo da servidão florestal ou a decisão do órgão federal executor do SISNAMA, em razão de degradação da vegetação nativa da área vinculada ao certificado de reserva florestal cujos custos e prazo de recuperação ambiental inviabilizassem a continuidade do vínculo entre a área e o título.

\subsection{6 Área de inclinação média:}

Prescreve o artigo 10, do Código Florestal, que não é permitida a derrubada de florestas situadas em áreas de inclinação entre 25 (vinte e cinco) e 45 (quarenta e cinco) graus, sendo nelas tolerada somente a extração de toros, quando em regime de utilização racional, que vise a rendimentos permanentes.

Este é mais um instrumento de proteção legal da flora, na medida em que limita o uso de florestas em áreas com determinada inclinação.

Isto não significa que o uso é totalmente interditado, pois o próprio artigo lança luzes quanto a um determinado uso permitido, quando houver regime de utilização racional para rendimento permanente, em que será permitida a extração de toros.

De qualquer forma, tal uso depende de manejo florestal sustentável, mediante prévio licenciamento ambiental.

Para a melhor interpretação de tal dispositivo, é relevante o conceito de "floresta", pois somente a ela se aplica a limitação e não às "demais formas de vegetação", na linguagem do próprio Código Florestal.

Assim, para as formações vegetais não florestais, assunto este abordado no item 1.1 deste trabalho, tal limitação do artigo 10, do Código Florestal, não é aplicável.

Luís Carlos Silva de Moraes ${ }^{118}$ pontua que tal artigo "completa o sistema de proteção criado no Código Florestal para as áreas vinculadas a elementos geográficos (arts. $2^{\circ}, 3^{\circ}$ e 10$) "$.

O doutrinador tem razão, pois, no artigo $2^{\circ}$, alínea e), do Código Florestal, é prevista como sendo área de preservação permanente legal nas áreas de encostas ou partes destas, com declividade superior a $45^{\circ}$ (quarenta e cinco graus), equivalente a $100 \%$ (cem por cento) na linha de maior declive.

Verifica-se, dessa forma, que se combinada a alínea e), do artigo $2^{\circ}$ com o artigo 10, ambos do Código Florestal, a exploração da floresta é totalmente proibida acima

\footnotetext{
${ }^{118}$ Código Florestal Comentado, São Paulo: Atlas, 2009. p.206
} 
dos $45^{\circ}$ (quarenta e cinco graus) de declividade, é limitada entre $25^{\circ}$ (vinte e cinco graus) e $45^{\circ}$ (quarenta e cinco graus) e, consequentemente, permitida em declividade menor do que $25^{\circ}$ (vinte e cinco graus).

Por isso, o doutrinador Luís Carlos Silva de Moraes ${ }^{119}$ denomina tal área de "área de transição", assim resumindo o teor do dispositivo:

Se os arts. $2^{\circ}$ e $3^{\circ}$ proíbem a exploração em áreas de declividade acima de 45 graus, $\mathrm{o}$ art. 10 permite a exploração da vegetação de floresta entre 25 e 45 graus de inclinação, instituindo uma "área de transição" entre a proibição total (APP) e as de exploração econômica intensiva (abaixo de 25 graus de declividade). Não é o caso de se prolongar aqui, mas vale informar que a pedologia e a geomorfologia, na maioria das vezes - cabem exceções - , dará uma aptidão agropecuária mais baixa para essas áreas, em razão do relevo e tipo de solo (normalmente em formação).

Finalmente, a área de inclinação média poderá ser computada para fins de reserva florestal legal, na medida em que não se trata de uma área de preservação permanente legal, por não se emoldurar à hipótese do artigo $2^{\circ}$, alínea e), do Código Florestal e desde que não seja instituída nela uma área de preservação permanente administrativa, pelo poder público, com fundamento numa das hipóteses do artigo $3^{\circ}$, do mesmo Código.

\subsubsection{Proibição individualizada de corte:}

A proibição individualizada de corte é objeto de disciplina do artigo $7^{\circ}$, do Código Florestal, e consiste na previsão de que qualquer árvore poderá ser declarada imune de corte, mediante ato do poder público, por motivo de sua localização, raridade, beleza ou condição de porta-sementes.

Não se vislumbra óbice à aplicação do dispositivo do Código Florestal a um grupo de árvores reunidas, que não poderão ser cortadas em razão da função ecológica que desempenham.

Trata-se de medida administrativa restritiva do direito de propriedade do particular, muito semelhante ao tombamento.

${ }^{119}$ Loc.cit. 
Na verdade, o tombamento visa atender o que dispõe o artigo $216, \S 1^{\circ}$, da Constituição Federal, que estabelece o dever do poder público, com colaboração da comunidade, de promover e proteger o patrimônio cultural brasileiro, por meio de inventários, registros, vigilância, tombamento e desapropriação, e de outras formas de acautelamento e preservação.

O tombamento, a rigor, é procedimento voltado a um objeto específico de proteção, relacionado muito mais com o conceito de meio ambiente cultural do que com o conceito de meio ambiente natural, onde a flora se insere.

A proibição individualizada de corte assemelha-se ao tombamento também no fato de, quanto ao alcance, ser uma restrição parcial do direito de propriedade, recaindo sobre determinado objeto específico.

Quanto às modalidades, também podem ser adaptadas à proibição individualizada de corte as mesmas do tombamento, a saber:

a) de ofício, quando ocorrer por iniciativa do órgão ambiental e recair sobre bem público;

b) compulsório, quando ocorrer por iniciativa do órgão ambiental e recair sobre bem particular;

c) voluntário, quando o próprio proprietário da árvore requerer a instituição de proibição individualizada de corte sobre ela.

Ainda, a proibição individualizada de corte assemelha-se ao tombamento na medida em que recai sobre um objeto específico, no caso a árvore ou grupo delas, e não sobre a propriedade como um todo.

Porém, aprofundando-se mais esta análise e com base na lição de Maria Sylvia Zanella Di Pietro ${ }^{120}$, a proibição individualizada de corte difere do tombamento na medida em que este visa preservação de "bens de qualquer natureza cuja conservação seja de interesse público, por sua vinculação a fatos memoráveis da história ou por seu excepcional valor arqueológico ou etnológico, bibliográfico ou artístico” (grifo nosso).

A natureza jurídica da proibição individualizada de corte não pode ser considerada limitação administrativa, pois dela difere no fato de não impor obrigações de caráter geral a proprietários indeterminados, como ocorre com a área de preservação permanente e reserva florestal legal, e sim limitação a um objeto específico, em caráter temporário eventualmente.

${ }^{120}$ Direito Administrativo, São Paulo: Atlas, 2008. p.128-129 
Também não se trata de uma servidão administrativa, na medida em que não é direito real de gozo, de natureza pública e instituído sobre imóvel de propriedade alheia, por entidade pública ou seus delegados, no interesse de um serviço público prestado ou de afetação a um fim de utilidade pública.

O objeto de proteção da proibição individualizada de corte é uma árvore ou grupo delas, com finalidade estritamente de conservação da flora.

Nota-se, porém, que é uma restrição parcial do direito de propriedade, não acarretando, por isso, tal como ocorre no tombamento, em regra, direito a indenização.

A indenização será devida, porém, quando acarretar a "impossibilidade total de exercício dos poderes inerentes ao domínio", tal como ocorre no tombamento.

Mesma opinião é a de Luís Carlos Silva de Moraes $^{121}$, em relação especificamente à proibição individualizada de corte de uma árvore: “(...) imposto um ônus sobre o proprietário do imóvel onde se localiza a referida árvore, necessária a indenização. Isso acontece quando as condições de conservação da coisa acarretarem despesas extraordinárias para o proprietário".

\subsubsection{Unidades de conservação:}

\subsubsection{Conceito e evolução:}

As unidades de conservação podem ser definidas sucintamente como áreas com relevante ecossistema criadas por lei e submetidas a um regime jurídico próprio de proteção.

No artigo $2^{\circ}$, inciso I, da Lei $\mathrm{n}^{\circ} 9.985$, de 18 de julho de 2000, a unidade de conservação é conceituada como espaço territorial e seus recursos ambientais, incluindo as águas jurisdicionais, com características naturais relevantes, legalmente instituído pelo poder público, com objetivos de conservação e limites definidos, sob regime especial de administração, ao qual se aplicam as garantias adequadas de proteção.

No tópico 1.4 deste trabalho foi brevemente descrita a legislação de proteção ao meio ambiente e à flora brasileira, tendo sido apontado que a Lei ${ }^{\circ}$ 9.985, de 18 de julho de 2000 instituiu o Sistema Nacional das Unidades de Conservação - SNUC.

${ }^{121}$ Op. cit., p. 191 
Trata-se de sistema, na medida em que as diversas modalidades de unidades de conservação são partes de um conjunto organizado, cujo funcionamento é regido pelas regras e princípios de tal lei.

A instituição desse sistema de unidades de conservação efetivou a regra do artigo 225, $\S 1^{\circ}$, inciso III, da Constituição Federal que obriga o poder público a definir, em todas as unidades da Federação, espaços territoriais especialmente protegidos, cuja alteração e supressão dependem de lei, vedada qualquer utilização que comprometa a integridade dos atributos que justifiquem tal proteção.

Mais adiante, no tópico 1.7.2, demonstrou-se que as unidades de conservação são espécies do gênero espaço territorial especialmente protegido e foram incluídos no Plano Estratégico Nacional de Áreas Protegidas - PNAP, juntamente com as terras indígenas, territórios quilombolas, áreas de preservação permanente e reserva florestal legal, plano este disciplinado pelo Decreto $\mathrm{n}^{\circ}$ 5.758, de 13 de abril de 2006.

Esta nova disciplina para tais áreas protegidas tem como antecedente histórico mais remoto a Lei $\mathrm{n}^{\mathrm{o}}$ 6.902, de 27 de abril de 1981, que criou as estações ecológicas e as áreas de proteção ambiental.

As estações ecológicas eram instituídas em áreas de domínio público da União, Estados, Distrito Federal e Municípios e as áreas de proteção ambiental em áreas privadas submetidas à restrições de uso.

Posteriormente, a Lei ${ }^{\circ}$ 6.938, de 31 de agosto de 1981 (Lei da Política Nacional do Meio Ambiente), alterada pela Lei $n^{\circ}$ 7.804, de 18 de julho de 1989, no seu artigo $9^{\circ}$, inciso VI, previu como instrumento de tal política a criação de espaços territoriais especialmente protegidos pelo Poder Público federal, estadual e municipal, tais como áreas de proteção ambiental, de relevante interesse ecológico e reservas extrativistas.

A mesma Lei da Política Nacional do Meio Ambiente, na redação original de seu artigo 18, transformou em reservas ou estações ecológicas as florestas e demais formas de vegetação natural de preservação permanente, relacionadas no artigo $2^{\circ}$, da Lei n 4.771 , de 15 de setembro de 1965, Código Florestal, portanto, mudou o regime jurídico das áreas de preservação permanente legais.

No Decreto $\mathrm{n}^{\circ}$ 89.336, de 31 de janeiro de 1984, ainda antes da atual ordem constitucional, em seu artigo $1^{\circ}$, houve a ampliação do regime jurídico das reservas ecológicas e áreas de relevante interesse ecológico, incluindo também as áreas de preservação permanente administrativas do artigo $3^{\circ}$, do Código Florestal. 
Segundo o regime jurídico instituído por tal diploma legal, as reservas ecológicas poderiam ser públicas ou privadas, dependendo de sua situação dominial e as estações ecológicas sempre eram públicas.

As áreas de relevante interesse ecológico, por sua vez, eram divididas em áreas de proteção ambiental, zonas de vida silvestre e estações ecológicas.

Destaca-se que tal diploma legal foi um embrião da organização de áreas com ecossistemas protegidos, antes mesmo da Constituição Federal de 1988.

Entretanto, o regime jurídico criado pelo artigo 18, da Lei da Política Nacional do Meio Ambiente, que transformou as áreas de preservação permanente em reservas ecológicas e estações ecológicas, foi revogado posteriormente pelo artigo 60, da Lei do Sistema Nacional das Unidades de Conservação.

Apesar de não constar revogação expressa da Lei $n^{\circ}$ 6.902, de 27 de abril de 1981 e do Decreto $n^{\text {o }}$ 89.336, de 31 de janeiro de 1984, em legislação posterior, é inegável que o regime jurídico das atuais unidades de conservação substituiu o regime criado por esses antigos instrumentos legais.

Tal assertiva se comprova pelo próprio fato do Sistema Nacional de Unidades de Conservação ser constituído pelo conjunto de unidades de conservação federais, estaduais e municipais e ter por objetivos a contribuição para a manutenção da diversidade biológica e dos recursos genéticos no território nacional e nas águas jurisdicionais, a proteção das espécies ameaçadas de extinção no âmbito regional e nacional, a contribuição para preservação e restauração da diversidade de ecossistemas naturais, promoção de desenvolvimento sustentável a partir dos recursos naturais, a promoção da utilização de princípios e práticas de conservação da natureza no processo de desenvolvimento, entre outros.

\subsubsection{Categorias de unidades de conservação:}

José Heder Benatti ${ }^{122}$ conceitua duas categorias de unidades de conservação:

a) áreas protegidas de domínio público, em que "obrigatoriamente são patrimônios públicos, não pertencem a particulares. Por isso, a necessidade de desapropriar todos os imóveis particulares existentes dentro das unidades";

${ }^{122}$ Posse Agroecológica \& Manejo Florestal à Luz da Lei 9.985/00, Curitiba: Juruá, 2008. p.154 
b) áreas protegidas mistas "(públicas e privadas) ou somente privadas (lembramos que neste último caso essa proteção é uma limitação administrativa ou exercício do direito de propriedade, por isso mesmo não indenizável)".

Essa classificação leva em conta o fato de existirem unidades de conservação compostas somente por áreas públicas e outras, tais como as áreas de proteção ambiental, áreas de relevante interesse ecológico, entre outras, poderem ser constituídas também por áreas privadas em seu interior.

Porém, tendo em vista o uso de tais unidades de conservação, a Lei $n^{\circ}$ 9.985, de 18 de julho de 2000, previu que são duas as categorias para as mesmas:

a) unidades de proteção Integral, cujo objetivo básico é a preservação da natureza, sendo admitida somente, em regra, o uso indireto dos seus recursos naturais;

b) unidades de uso sustentável, cujo objetivo básico é compatibilizar a conservação da natureza com o uso sustentável de parcela dos seus recursos naturais.

Segundo definição constante na própria Lei do Sistema Nacional de Unidades de Conservação, o uso indireto é aquele que não envolve consumo, coleta, dano ou destruição dos recursos naturais e o uso sustentável é aquele em que a exploração do ambiente é feita de maneira a garantir a perenidade dos recursos ambientais renováveis e dos processos ecológicos, mantendo a biodiversidade e os demais atributos ecológicos, de forma socialmente justa e economicamente viável.

As espécies de unidades de proteção integral são as seguintes:

a) estação ecológica;

b) reserva biológica;

c) parque nacional;

d) monumento natural;

e) refúgio da vida silvestre.

As estações ecológicas são de posse e domínio públicos, sendo que as áreas particulares eventualmente nelas incluídas devem ser desapropriadas.

Nelas é vedada a visitação pública, exceto com objetivo educacional e conforme o plano de manejo e regulamento da unidade e a pesquisa científica é permitida mediante autorização prévia do órgão gestor da unidade, conforme regulamento.

As alterações no ecossistema das estações ecológicas são admitidas somente quando as medidas visem a restauração de ecossistemas modificados, o manejo de espécies com o fim de preservar a diversidade biológica, a coleta de componentes dos ecossistemas com finalidade científica e pesquisas científicas cujo impacto sobre o 
ambiente seja maior do que aquele causado pela simples observação ou pela coleta controlada de componentes dos ecossistemas, em área correspondente a no máximo três por cento da extensão total da unidade e até o limite de mil e quinhentos hectares.

$\mathrm{O}$ estabelecimento de limites territoriais, mesmo no desenvolvimento de pesquisas científicas, visa a proteção do ecossistema, devendo tal atividade também estar previamente autorizada pelo órgão administrativo gestor da unidade e conforme seu plano de manejo ou regulamento.

Pontua-se que estas estações ecológicas não se confundem com aquelas criadas pela Lei ${ }^{\circ} 6.902$, de 27 de abril de 1981.

A reserva biológica objetiva a preservação integral da biota e demais atributos naturais existentes nos seus limites, sem interferência humana direta ou modificações ambientais, com exceção das medidas de recuperação de seus ecossistemas alterados e as ações de manejo necessários para recuperar e preservar o equilíbrio natural, a diversidade biológica e os processos ecológicos naturais.

Também se trata de unidade de posse e domínio públicos, devendo ser desapropriadas eventuais áreas particulares incluídas em seus limites e sendo nela também vedada a visitação pública, exceto com objetivo educacional, conforme regulamento específico.

Quanto à pesquisa científica, é dependente de autorização prévia do órgão gestor da unidade e deve observar as condições e restrições estabelecidas por tal órgão, conforme regulamento.

O parque nacional tem sua razão de existir na preservação de ecossistemas naturais de grande relevância e beleza cênicas, podendo em seus limites ser realizadas pesquisas científicas, o desenvolvimento de atividades de educação e interpretação ambiental, recreação em contato com a natureza e o turismo ecológico.

Da mesma forma que as anteriores, possui natureza jurídica pública, devendo as áreas existentes em seus limites ser desapropriadas.

A visitação pública se sujeita às normas e restrições constantes no plano de manejo da unidade, às normas emanadas da autoridade gestora e regulamento e a pesquisa científica é dependente de autorização prévia de tal autoridade.

Poderão existir parques estaduais, distritais e municipais criados pelos demais entes da federação, cujo regramento básico é o da Lei do Sistema Nacional de Unidades de Conservação. 
O refúgio da vida silvestre visa a proteção dos ambientes naturais onde se asseguram condições de existência ou reprodução de espécies ou comunidades da flora local e da fauna residente ou migratória.

Diferentemente das outras espécies de unidades de proteção integral, tal categoria pode ser composta por áreas particulares, desde que seja possível a compatibilidade dos objetivos da unidade com o uso da terra e dos recursos naturais do local dos proprietários.

Caso haja incompatibilidade entre os objetivos da área e as atividades privadas nela desenvolvidas, ou quando houver discordância por parte do proprietário das condições propostas pelo órgão administrativo gestor da unidade, a área privada deve ser desapropriada.

A visitação pública é permitida, assim como a pesquisa científica, desde que conforme as condições e restrições estabelecidas em plano de manejo e regulamento da unidade.

O grupo das unidades de uso sustentável é composto pelas seguintes categorias:

a) área de proteção ambiental;

b) área de relevante interesse ecológico;

c) floresta nacional;

d) reserva extrativista;

e) reserva da fauna;

f) reserva de desenvolvimento sustentável;

g) reserva particular do patrimônio natural.

A área de proteção ambiental é constituída por áreas públicas e privadas, normalmente extensas, com certo grau de ocupação humana, sendo dotada de atributos abióticos, bióticos, estéticos ou culturais especialmente importantes para a qualidade de vida e o bem estar das populações humanas, tendo por objetivo básico proteger a biodiversidade biológica, disciplinar o processo de ocupação e assegurar a sustentabilidade do uso dos recursos naturais.

Nela é possível a visitação pública e o desenvolvimento de pesquisas científicas, conforme regras estabelecidas pelo órgão gestor da unidade, na porção pública da área. Na porção privada, compete ao proprietário estabelecer as condições de pesquisa científica e visitação pública, observadas restrições legais. 
$\mathrm{Na}$ sua gestão deve funcionar um conselho presidido pelo órgão administrativo gestor e composto por representantes das entidades públicas, das organizações da sociedade civil e da população residente, conforme o regulamento da unidade.

A área de relevante interesse ecológico também pode ser constituída por terras pública e/ou privadas, porém normalmente de pequena extensão, com pouca ou nenhuma ocupação humana, com características naturais extraordinárias ou que abriga exemplares raros da biota regional.

O objetivo de tal unidade de uso sustentável é a manutenção dos ecossistemas naturais de importância regional ou local e regular o uso admissível dessas áreas, de modo a compatibilizá-lo com a conservação da natureza.

A floresta nacional é uma área com cobertura florestal de espécies predominantemente nativas e tem como objetivo básico o uso múltiplo sustentável dos recursos naturais e a pesquisa científica, com ênfase em métodos para exploração sustentável de florestas nativas.

Tal unidade de uso sustentável sempre será de posse e domínio públicos, devendo as áreas particulares existentes dentro de seus limites ser desapropriadas.

Também é permitida a permanência nelas de populações tradicionais que a habitam quando de sua criação, a visitação pública e pesquisa científica, esta última devendo ser incentivada, tudo conforme o disposto em regulamento e no plano de manejo da unidade.

$\mathrm{Na}$ administração da floresta nacional deve existir um conselho consultivo, presidido pelo seu órgão público gestor e constituído de órgãos públicos, organizações da sociedade civil e das populações residentes.

Quando criadas pelos Estados e Municípios, as unidades podem ser denominadas florestas estaduais e florestas municipais, respectivamente.

A reserva extrativista é área utilizada por populações tradicionais, cuja subsistência baseia-se na agricultura, criação de animais de pequeno porte e extrativismo, sendo o objetivo da instituição deste tipo de unidade é justamente a proteção dos meios de vida e cultura de tais populações compatível com o uso sustentável dos recursos naturais de tal unidade.

Essa unidade é composta por áreas de domínio público concedidas às populações extrativistas tradicionais, que se obrigam a preservá-la, recuperá-la, defendê-la 
e mantê-la, sendo que as áreas privadas, eventualmente existentes dentro de seus limites, devem ser desapropriadas.

A referida concessão, na verdade, trata-se de concessão de direito real de uso instrumentalizada por um termo de compromisso firmado entre o poder público e as populações tradicionais que habitem na reserva extrativista, cuja regulamentação encontrase no Decreto ${ }^{\circ} 4.340$, de 22 de agosto de 2002 (Regulamento da Lei do Sistema Nacional de Unidades de Conservação).

A gestão de tal unidade é feita por um conselho deliberativo, composto por representantes do poder público, de organizações da sociedade civil e das populações tradicionais residentes na sua área, conselho este que deve aprovar o plano de manejo da área.

A visitação pública e pesquisa científica são permitidas, desde que mediante prévia autorização do órgão ambiental e conforme o plano de manejo e regulamento da unidade, sendo proibida exploração de recursos minerais, caça amadora ou profissional.

A exploração comercial de recursos madeireiros é permitida somente se realizada com bases sustentáveis, em situações especiais e complementares às principais atividades que devem ser desenvolvidas na unidade, previstas no seu plano de manejo e regulamento.

A reserva da fauna é uma área natural com populações animais de espécies nativas, terrestres ou aquáticas, residentes ou migratórias, adequadas para estudo técnico-científicos sobre o manejo econômico sustentável de recursos faunísticos.

Trata-se também de unidade composta por áreas de domínio públicos, sendo que as áreas particulares incluídas em seus limites devem ser desapropriadas, sendo permitida a visitação pública, desde que adequada ao plano de manejo da unidade e de acordo com as normas estabelecidas pelo órgão responsável por sua administração.

Até por ser unidade de proteção da fauna, é proibida a caça amadora ou profissional e a comercialização dos produtos e subprodutos resultantes de pesquisas deve obedecer ao disposto nas leis sobre fauna e regulamentos.

A reserva de desenvolvimento sustentável é área natural que também abriga populações tradicionais, cuja existência baseia-se em sistemas sustentáveis de exploração dos recursos naturais, desenvolvidos ao longo de gerações e adaptados às condições ecológicas locais e que desempenham um papel fundamental na proteção da natureza e na manutenção da diversidade biológica. 
Seu objetivo é preservar a natureza e, ao mesmo tempo, assegurar as condições e meios necessários para a reprodução e a melhoria dos modos e da qualidade de vida e exploração dos recursos naturais das populações tradicionais, bem como valorizar, conservar e aperfeiçoar o conhecimento e as técnicas de manejo do ambiente, desenvolvido por estas populações.

Trata-se, também, de unidade de domínio público, devendo ser desapropriadas as áreas particulares incluídas em seus limites.

Da mesma forma que a reserva extrativista, a gestão da reserva de desenvolvimento sustentável é atribuída a um conselho deliberativo, com representação do poder público, de organizações da sociedade civil e das populações tradicionais residentes na área, conforme regulamento.

A visitação pública é permitida e incentivada, devendo ser compatível com os interesses locais e com o plano de manejo, assim como a pesquisa científica, que deve ser voltada à conservação da natureza e ser previamente autorizada pelo órgão administrador da unidade.

Admite-se exploração de componentes dos ecossistemas naturais somente em regime de manejo sustentável, a substituição da cobertura vegetal por espécies cultiváveis, desde que sujeitas ao zoneamento, devendo, em ambas as atividades, ser observados os limites legais e técnicos constantes no plano de manejo da área.

Tal plano de manejo deve ser aprovado pelo conselho deliberativo da unidade e contemplar as zonas de proteção integral, as zonas de uso sustentável, as zonas de amortecimento e os corredores ecológicos, atentando-se para o equilíbrio dinâmico entre o tamanho da população e a conservação.

A reserva particular do patrimônio natural é uma área privada, criada com o fim de conservar a diversidade biológica por meio de um gravame perpétuo, constituído de termo de compromisso estabelecido perante o órgão ambiental, posteriormente averbado à margem da matrícula do imóvel no registro público de imóveis.

As atividades permitidas na reserva particular do patrimônio natural, conforme regulamento, são a pesquisa científica e visitação com objetivos turísticos, recreativos e educacionais. 


\subsubsection{Criação, modificação, funcionamento e extinção de unidades de conservação.}

A Lei $n^{\circ} 9.985$, de 18 de julho de 2000 , em obediência ao artigo $225, \S 1^{\circ}$, inciso III, da Constituição Federal, determina que a criação, modificação e extinção de unidade de conservação deve ser feita por meio de lei específica, precedida de estudos técnicos e participação popular por meio de consultas públicas.

No aludido procedimento de criação, é facultada a consulta pública somente para a estação ecológica e a reserva biológica, sendo obrigatória para as demais categorias.

O doutrinador Saint-Clair Honorato Santos ${ }^{123}$, considera “(...) salutar providência, já que de bom alvitre estudar o local pretendido, bem como discutir com a comunidade a sua criação, demonstrando-se o endereçamento constitucional da participação pública nos atos da administração".

A unidade de conservação também deve possuir uma zona de amortecimento e corredores ecológicos.

A primeira é conceituada como entorno da unidade de conservação onde as atividades humanas sofrem restrições com a finalidade de se minimizar impactos negativos sobre tal unidade.

A segunda é conceituada como partes de ecossistemas naturais ou seminaturais de interligação de unidades de conservação, pelos quais se possibilita o fluxo de genes e movimento da biota, auxiliando na dispersão de espécies, recolonização de áreas degradadas e manutenção de populações que exijam área de maior extensão do que da unidade individual para a sua sobrevivência.

Compete ao órgão gestor da unidade de conservação estabelecer as regras de ocupação e uso dos recursos naturais da zona de amortecimento e dos corredores ecológicos.

O subsolo e o espaço aéreo, sempre que influenciarem na estabilidade do ecossistema, também devem integrar os limites da unidade de conservação.

Um conjunto de unidades de conservação de categorias diversas, ou não, constitui o denominado "mosaico", cuja gestão deve ser feita de forma integrada e participativa, compatibilizando-se os diferentes objetivos de conservação e valorizando-se a presença da biodiversidade, da sociodiversidade e do desenvolvimento sustentável no contexto regional.

\footnotetext{
${ }^{123}$ Direito Ambiental, Unidades de Conservação, Limitações Administrativas, Curitiba: Juruá, 2008. p. 88
} 
Segundo o Decreto $n^{\circ} 4.340$, de 22 de agosto de 2002 (Regulamento da Lei do Sistema Nacional de Unidades de Conservação), os corredores ecológicos também compõem o mosaico, cuja gestão deverá também ser realizada por um conselho.

A gestão técnica da unidade de conservação é regrada por seu plano de manejo, instrumento que deve abranger a sua área, a zona de amortecimento e corredores ecológicos e que deve buscar proporcionar a integração da vida econômica e social das comunidades vizinhas, tanto que, em sua elaboração, atualização e implementação deve ser assegurada ampla participação da população residente.

Denota-se que é uma tônica na criação e gestão das unidades de conservação a participação popular e daqueles que são diretamente envolvidos com a unidade, contemplando-se, na legislação, o princípio democrático e o dever imposto pelo artigo 225, "caput", da Constituição Federal, à participação da coletividade nas questões ambientais.

Mais uma vez, Saint-Clair Honorato Santos ${ }^{124}$ entende que houve “(...) intenção do legislador em obedecer ao princípio constitucional da democracia participativa, garantindo à sociedade civil a possibilidade de integrar conselhos e encaminhar soluções que interessassem à comunidade" (grifo nosso, itálico do original).

Na gestão da unidade de conservação, ainda, é permitido entabulamento de parcerias com organizações da sociedade civil de interesse público, cujos objetivos institucionais tenham afinidade com os da unidade, além de comprovar a realização de atividades de proteção do meio ambiente ou desenvolvimento sustentável, preferencialmente na unidade de conservação ou no mesmo bioma.

Nos artigos 21 a 24, do Regulamento da Lei do Sistema Nacional de Unidades de Conservação, são estabelecidos os contornos básicos dessa parceria com organizações da sociedade civil de interesse público visando a gestão de unidade de conservação.

Consta em tais dispositivos, que a parceria é regulada por um termo de referência definido pelo órgão gestor, ouvido o conselho da unidade, devendo ocorrer um procedimento de chamada pública, por meio de edital, para o seu estabelecimento.

Em regra, é proibida a introdução nas unidades de conservação de espécies não autóctones, exceção feita às áreas de proteção ambiental, as florestas nacionais, as reservas extrativistas, reservas de desenvolvimento sustentável, aos animais e

${ }^{124}$ Op. cit., p. 89 
plantas necessários à administração e outras atividades, desde que conforme o plano de manejo da unidade de conservação, às áreas particulares localizadas em refúgio de vida silvestre e monumentos naturais, onde podem ser criados animais domésticos e cultivadas plantas que guardem compatibilidade com os fins da unidade, na forma do plano de manejo.

As pesquisas científicas nas unidades de conservação devem ser previamente aprovadas pelos seus órgãos administradores e sofrem fiscalização, estando excluídas dessa regra a área de proteção ambiental e a reserva particular do patrimônio natural, conforme $\S 2^{\circ}$, do artigo 32 , da Lei do Sistema Nacional de Unidades de Conservação.

Os frutos financeiros de pesquisas científicas desenvolvidas em unidade de conservação, por sua vez, merecem ser disciplinados de tal forma que revertam para a sociedade, dada a própria natureza do bem ambiental, opinião que é compartilhada por Saint-Clair Honorato Santos ${ }^{125}$, que sobre o assunto assim se manifestou:

A atividade de pesquisa, ao nosso ver, deve estar sempre subordinada à administração do poder público, quando realizadas em unidades de conservação, bem como garantidos os eventuais lucros daí decorrentes, em contratos bem elaborados, para que, como nos casos atuais de biodiversidade, garantam a devida remuneração à população brasileira, através da participação da universidade, para que não estejamos alienando a outros países o nosso conhecimento tradicional e científico, e para que redunde em benefício da nossa própria população.

A exploração de produtos, subprodutos ou serviços obtidos ou desenvolvidos dos recursos naturais, biológicos, cênicos ou culturais, assim como da imagem da unidade de conservação, com exceção da área de proteção ambiental e reserva particular do patrimônio natural, depende de prévia autorização e sujeita o explorador a pagamento de preço.

Os recursos usados na manutenção da unidade de conservação podem advir também de doações, nacionais ou internacionais, com ou sem encargos e provir de pessoas jurídicas privadas ou públicas e de pessoas físicas, cabendo sua administração ao órgão gestor da unidade.

${ }^{125}$ Op. cit. , p. 90 
O artigo 45, do Regulamento da Lei do Sistema Nacional de Unidades de Conservação, determina que cada categoria de unidade de conservação deve ser objeto de regulamentação específica.

As unidades de conservação fazem parte do acervo patrimonial do ente público União, uma vez que são bens públicos imóveis, porém a sua administração é supervisionada pelo Ministério do Meio Ambiente, por intermédio da autarquia federal Instituto Chico Mendes de Conservação da Biodiversidade, criada pela Lei $\mathrm{n}^{\circ} 11.516$, de 28 de agosto de 2007 e cujos objetivos são, conforme artigo $1^{\circ}$ :

I - executar ações da política nacional de unidades de conservação da natureza, referentes às atribuições federais relativas à proposição, implantação, gestão, proteção, fiscalização e monitoramento das unidades de conservação instituídas pela União;

II - executar as políticas relativas ao uso sustentável dos recursos naturais renováveis e ao apoio ao extrativismo e às populações tradicionais nas unidades de conservação de uso sustentável instituídas pela União;

III - fomentar e executar programas de pesquisa, proteção, preservação e conservação da biodiversidade e de educação ambiental;

IV - exercer o poder de polícia ambiental para a proteção das unidades de conservação instituídas pela União; e

$\mathrm{V}$ - promover e executar, em articulação com os demais órgãos e entidades envolvidos, programas recreacionais, de uso público e de ecoturismo nas unidades de conservação, onde estas atividades sejam permitidas.

\subsubsection{Outras formas de proteção da flora:}

Além dos instrumentos estudados, previstos basicamente no Código Florestal e na Lei do Sistema Nacional de Unidades de Conservação, existem outros instrumentos previstos em leis específicas, com a mesma finalidade de proteção dos ecossistemas, neles se incluindo a flora.

As unidades de conservação submetem-se a um regramento legal próprio que não se confunde com as unidades ambientais analisadas, entendimento compartilhado por Américo Luís Martins da Silva ${ }^{126}$, para que, estas últimas dizem respeito "à unidade funcional de planejamento e gestão ambiental" e que, na prática, pode ser definida "pelos limites político-administrativos relativos à área de jurisdição da autoridade a quem compete geri-la".

${ }^{126}$ Direito do Ambiente e dos Recursos Naturais, São Paulo: Revista dos Tribunais, 2005. p. 130 
Adiante, são enfrentados dois instrumentos previstos na citada Lei do Sistema Nacional de Unidades de Conservação, além de outras formas previstas em leis específicas.

\subsection{Reserva da biosfera:}

A reserva da biosfera é disciplinada no artigo 41, da Lei do Sistema Nacional de Unidades de Conservação, não se constituindo propriamente numa unidade de conservação, mas num modelo de gestão integrada, participativa e sustentável dos recursos naturais, composta por áreas públicas ou privadas.

Os seus objetivos básicos são a preservação da biodiversidade, o desenvolvimento das atividades de pesquisa científica, o monitoramento ambiental, a educação ambiental, o desenvolvimento sustentável e a melhoria de vida das populações.

Tal reserva da biosfera é constituída por uma ou várias áreas destinadas à proteção da integral da natureza, uma ou várias zonas de amortecimento, onde não são admitidas apenas atividades que não ocasionem dano às áreas-núcleo e uma ou várias zonas de transição, sem limites rígidos, onde a ocupação e manejo de recursos naturais é conduzida de modo participativo e segundo bases sustentáveis.

Também, pode ser formada por um conjunto de unidades de conservação criadas pelo poder público, respeitadas as normas de manejo de cada categoria.

Sua gestão é desenvolvida por um conselho deliberativo, em cuja composição há representantes do poder público, das organizações da sociedade civil e da população residente na área, respeitando as normas do regulamento ou de seu ato de constituição.

\subsection{Ilhas oceânicas, lacustres e de rios:}

Também na Lei do Sistema Nacional de Unidades de Conservação, no artigo 44, é previsto que as ilhas oceânicas e costeiras destinam-se prioritariamente à proteção da natureza, sendo que fins diversos devem ser precedidos de autorização do órgão ambiental competente.

Além das ilhas oceânicas, as ilhas lacustres e de rios desempenham importante função ambiental de proteção da flora. 
Tais ilhas existentes em rios, lagos e estuários são disciplinadas pela Resolução CONAMA, no 302, de 20 de março de 2002, que também considera as ilhas existentes em reservatórios de usinas hidrelétricas área de preservação permanente.

\subsection{Hortos florestais:}

No governo do Presidente Getulio Vargas foi criado o Serviço Florestal pelo Decreto-lei n ${ }^{\circ}$ 982, de 23 de dezembro de 1938, cuja atribuição era a proteção das florestas do país, sua guarda e conservação, o fomento da silvicultura e a organização de parques nacionais, de reservas florestais e de florestas típicas, tudo de acordo com o antigo Código Florestal.

Pelo Decreto $\mathrm{n}^{\mathrm{o}}$ 4.439, de 26 de julho de 1939, o Serviço Florestal foi estruturado com os seguintes órgãos: Secção de Botânica, Secção de Silvicultura, Secção de Tecnologia de Produtos Florestais e Secção de Parques Nacionais.

A Secção de Botânica era composta pelo Jardim Botânico e suas dependências, acrescido da área do antigo Horto Florestal da Gávea com as respectivas instalações.

$\mathrm{Na}$ Secção de Silvicultura, foram incluídos os hortos florestais dos Estados e o do Distrito Federal, que deveriam ter área mínima de 500 (quinhentos) hectares de terras servidas por curso d'água e localização em zona salubre servida por estradas de ferro, companhias de navegação ou estrada de rodagem.

Portanto, essa a origem legal histórica dos hortos florestais que, com as reformas legislativas foram repassados à administração do antigo Instituto Brasileiro de Desenvolvimento Florestal - IBDF, pelo Decreto-lei no 289, de 28 de novembro de 1967 e, finalmente, ao Instituto Brasileiro do Meio Ambiente e dos Recursos Naturais Renováveis - IBAMA, pela Lei n ${ }^{\circ}$ 7.735, de 22 de fevereiro de 1989.

Na Resolução CONAMA no 11, de 03 de dezembro de 1987, os hortos florestais foram incluídos na lista de sítios ecológicos de relevância cultural, não havendo uma regulamentação em lei atual.

No artigo 55, da Lei do Sistema Nacional de Unidades de Conservação, previu-se que as unidades de conservação e áreas protegidas criadas com base em legislações anteriores e não pertençam às categorias nela previstas seriam revalidadas, entre elas, tais hortos florestais. 


\subsection{Jardins zoológicos:}

Os jardins zoológicos são definidos na Lei ${ }^{\circ} 7.173$, de 14 de dezembro de 1983, como qualquer coleção de animais silvestres mantidos vivos em cativeiro ou em semiliberdade e expostos à visitação pública, com finalidade sócio-culturais e objetivos científicos.

A ênfase, portanto, nos jardins zoológicos é a fauna, porém não se pode desprezar o ecossistema como um todo, inclusive a flora, como elemento de proteção por tal instrumento também.

A instalação de jardins zoológicos pode se dar em áreas de domínio público ou privado, mediante prévio registro regulamentado pela Portaria IBAMA $\mathrm{n}^{\circ}$ 283/P, de 18 de maio de 1989.

\subsection{Paralelograma de cobertura florestal:}

Na Lei $n^{\circ} 7.754$, de 14 de abril de 1989, repetindo o que previa o Código Florestal, se estabeleceu que as florestas e demais formas de vegetação natural existentes nas nascentes dos rios são consideradas de preservação permanente.

Para melhor proteção das nascentes, o mesmo diploma legal instituiu o paralelograma de cobertura florestal, uma área em forma de paralelograma em que são vedadas a derrubada de árvores e qualquer forma de desmatamento, sendo que aquelas que estivessem degradadas, quando da edição da lei, deveriam ser recuperadas.

Segundo tal lei, as dimensões do paralelograma de cobertura florestal deveriam ser objeto de regulamento, levando-se em conta o comprimento e largura dos rios cujas nascentes seriam protegidas.

A citada regulamentação não adveio e a figura do paralelograma de cobertura florestal é pouco conhecida e utilizada, uma vez que a proteção de nascentes está incluída entre uma das áreas de preservação permanente legal, dispostas no artigo $2^{\circ}$, do Código Florestal.

\subsection{Zona de preservação da vida silvestre:}

No Decreto $\mathrm{n}^{\mathrm{o}}$ 89.336, de 31 de janeiro de 1984, foram disciplinadas as antigas reservas ecológicas e áreas de relevante interesse ecológico, que, por seu turno, 
constituíam as chamadas áreas de proteção ambiental, regulamentando-se a sistemática então existente inaugurada pela Lei nº 6.902, de 27 de abril de 1981.

Portanto, essa sistemática é anterior à instituição do conceito de espaço territorial especialmente protegido, pelo artigo 225, $\S 1^{\circ}$, inciso III, da Constituição Federal e do Sistema Nacional de Unidades de Conservação pela Lei $n^{\circ}$ 9.985, de 18 de julho de 2000, decorrente daquele dispositivo constitucional.

No contexto pré-Sistema Nacional de Unidades de Conservação, a Resolução CONAMA $n^{\circ}$ 10, de 14 de dezembro de 1988, previu que as antigas reservas ecológicas, públicas ou privadas, e “outras áreas com proteção legal equivalente”, existentes no território das antigas áreas de proteção ambiental, constituíam-se em zonas de preservação de vida silvestre, nelas sendo proibidas atividades que ocasionassem alteração antrópica da biota.

No mesmo ato administrativo normativo foi disciplinada a zona de conservação da vida silvestre, em áreas nas quais era admitido um uso demorado e autosustentado da biota, porém regulado para assegurar a manutenção dos ecossistemas naturais.

Nestas zonas de conservação da vida silvestre, a norma proibia a utilização de agrotóxicos, cultivo da terra que não observasse práticas de conservação do solo recomendadas pelos órgãos oficiais, pastoreio excessivo, terraplanagem, mineração, dragagem e escavação, havendo também restrições para atividades industriais e empreendimentos imobiliários.

O interesse sobre tais áreas, na atualidade, resume-se ao histórico, uma vez que, apesar da legislação citada não ter sido revogada expressamente, sem dúvida houve uma modificação de regime jurídico e de gestão dos atuais espaços territoriais especialmente protegidos.

\subsubsection{7 Áreas especiais de interesse turístico e locais de interesse turístico:}

A Lei $n^{\circ}$ 6.513, de 20 de dezembro de 1977, disciplina as áreas especiais de interesse turístico e os locais de interesse turístico.

As primeiras são conceituadas como trechos contínuos do território nacional, inclusive suas águas territoriais, preservados e valorizados no sentido cultural e natural, destinados à realização de planos e projetos de desenvolvimento turístico. 
Já, os locais de interesse turístico são trechos do território nacional, compreendidos ou não nas primeiras, destinados por sua adequação ao desenvolvimento de atividades turísticas e à realização de projetos específicos que compreendam bens não sujeitos a regime específico de proteção e os respectivos entornos de proteção e ambientação.

O entorno de proteção, por sua vez, é o espaço físico necessário ao acesso do público ao local de interesse turístico e à sua conservação, manutenção e valorização e o entorno de ambientação é o espaço físico necessário à harmonização do local de interesse turístico com a paisagem em que se situar.

A referida lei não foi revogada e as áreas existentes sob tais formas jurídicas, antes da entrada em vigor da lei do sistema nacional de unidades de conservação, foram mantidas, sendo, porém, de restrita ou nenhuma ocorrência nos dias atuais.

$\mathrm{O}$ objeto principal da proteção ambiental nessas áreas, além do meio ambiente natural, é também o meio ambiente cultural no atendimento da atividade específica de turismo, não sendo, portanto, instrumento voltado especificamente à defesa da flora.

\subsection{Usos da floresta e formações sucessoras:}

$\mathrm{O}$ assunto tratado neste tópico relaciona-se diretamente com o tema central deste trabalho, a concessão florestal.

O uso ou exploração da floresta é tratado, em termos gerais, no próprio Código Florestal, que, no seu artigo 19, determina que tal exploração de florestas e formações sucessoras, tanto de domínio público como de domínio privado, depende de prévia aprovação pelo órgão estadual competente do Sistema Nacional do Meio Ambiente - SISNAMA que verificará a adoção de técnicas de condução, exploração, reposição florestal e manejo compatíveis com os vários ecossistemas formados pela cobertura arbórea.

A competência do órgão estadual, porém, não afasta a competência do Instituto Brasileiro de Meio Ambiente - IBAMA para a aprovação da exploração de florestas públicas e unidades de conservação criadas pela União, assim como a exploração de florestas em empreendimentos potencialmente causadores de impacto ambiental nacional ou regional. 
O mesmo ocorre em relação aos Municípios, a quem o Código Florestal, com redação alterada pela Lei no 11.284, de 02 de março de 2006 (Lei Geral de Gestão das Florestas Públicas), incumbiu de aprovar a exploração de florestas e unidades de conservação por eles criadas e em casos de delegação por convênio ou outro instrumento, ouvidos os órgãos competentes das demais esferas federativas.

O Código Florestal, em seu artigo 12, permite a livre exploração em florestas plantadas, não consideradas de preservação permanente, de onde também se pode extrair lenha e demais produtos florestais ou fabricar-se carvão, sendo que, nas demais florestas, depende de regulamentação do órgão ambiental.

No artigo 15, do Código Florestal, há clara proibição a exploração sob a forma empírica de florestas primitivas da bacia amazônica, que só poderão ser utilizadas em observância a planos técnicos de condução e manejo.

Quanto à reposição florestal, reza o artigo $19, \S 3^{\circ}$, que devem ser priorizados projetos que contemplem a utilização de espécies nativas, por ser esta a melhor forma de se repor o ecossistema como um todo.

O Código Florestal, em linhas gerais, também disciplinou os diferentes empreendimentos e atividades em que a exploração da floresta deve ser regrada de forma mais específica:

a) os assentamentos humanos ou de colonização para fim de reforma agrária;

b) as empresas industriais consumidoras de grande quantidade de matéria prima florestal;

c) as empresas siderúrgicas, de transporte e outras, que funcionem movidas por carvão vegetal, lenha ou outra matéria-prima florestal.

Sobre os assentamentos humanos ou de colonização para fim de reforma agrária, prevê o artigo 19, do Código Florestal, que é proibida a implantação de tais projetos em áreas com cobertura florestal primária e secundária, com estágio avançado de regeneração, com exceção somente aos assentamentos agro-extrativistas regulamentados por legislação específica.

Para as empresas industriais consumidoras de grande quantidade de matéria prima florestal, o Código Florestal impõe a obrigação de manterem, dentro de um raio em que a exploração e o transporte sejam julgados econômicos, um serviço organizado que assegure o plantio de novas áreas, em terras próprias ou de terceiros, cuja produção sob exploração racional seja equivalente ao consumido para seu abastecimento.

As empresas siderúrgicas, de transporte e outras, que funcionem movidas por carvão vegetal, lenha ou outra matéria-prima florestal, são obrigadas a manter florestas 
próprias para exploração racional ou a formar, diretamente ou por intermédio de empreendimentos dos quais participem, florestas destinadas ao seu suprimento.

O Decreto $\mathrm{n}^{\mathrm{o}}$ 5.975, de 30 de novembro de 2006, regulamenta os dispositivos do Código Florestal supra comentados, estabelecendo normas para a exploração de florestas e formações sucessoras, sob dois regimes, a saber:

a) regime de manejo florestal sustentável;

b) regime de supressão de florestas e formações sucessoras para uso alternativo do solo.

Segue adiante o detido estudo de cada um deles.

\subsubsection{Regime de manejo florestal sustentável:}

A Lei $n^{\circ} 11.284$, de 02 de março de 2006 (Lei de Gestão das Florestas Públicas), em seu artigo $3^{\circ}$, inciso VI, conceitua o manejo florestal sustentável como "administração da floresta para a obtenção de benefícios econômicos, sociais e ambientais, respeitando-se os mecanismos de sustentação do ecossistema objeto do manejo e considerando-se, cumulativa ou alternativamente, a utilização de múltiplas espécies madeireiras, de múltiplos produtos e subprodutos não madeireiros, bem como a utilização de outros bens e serviços de natureza florestal".

Portanto, tal regime visa permitir basicamente ao homem retirar da floresta todos os produtos e serviços por ela fornecidos, porém sem destruir o seu ecossistema.

Para que tal regime de manejo florestal sustentável possa ser autorizado pelo órgão ambiental do Sistema Nacional do Meio Ambiente - SISNAMA, deve ser antecedido de um documento técnico composto por diretrizes e procedimentos para a administração da floresta que, uma vez aprovado, confere ao detentor a licença ambiental para a prática do referido manejo.

Tal plano de manejo deverá ser anualmente relatado à autoridade ambiental, que, por sua vez, fiscalizará sua aplicação.

No plano de manejo florestal sustentável, devem ser atendidos os seguintes fundamentos técnicos e científicos:

a) caracterização do meio físico e biológico;

b) determinação do estoque existente;

c) intensidade de exploração compatível com a capacidade da floresta; 
d) ciclo de corte compatível com o tempo de restabelecimento do volume de produto extraído da floresta;

e) promoção de regeneração natural da floresta;

f) adoção de sistema silvicultural adequado;

g) adoção de sistema de exploração adequado;

h) monitoramento do desenvolvimento da floresta remanescente;

i) adoção de medidas mitigadoras dos impactos ambientais e sociais.

A supressão de florestas e formações sucessoras para uso alternativo do solo, devidamente autorizada, e o manejo de florestas plantadas localizadas fora de áreas de reserva florestal legal não exigem a aprovação de plano de manejo florestal sustentável.

1.8.2 Regime de supressão a corte raso de florestas e formações sucessoras para uso alternativo do solo:

O uso alternativo do solo é conceituado como a substituição de florestas e formações sucessoras por outras coberturas do solo, tais como projetos de assentamento para reforma agrária, agropecuários, industriais, de geração e transmissão de energia, de mineração e de transporte.

Tais atividades devem ser previamente autorizadas pelo órgão competente do Sistema Nacional do Meio Ambiente - SISNAMA, que verificará se o requerimento de autorização contém, no mínimo, a localização georreferenciada do imóvel, das áreas de preservação permanente e de reserva legal florestal, o cumprimento da reposição florestal, a efetiva utilização de áreas já convertidas e o uso alternativo a que será destinado o solo a ser desmatado.

O pequeno proprietário rural ou possuidor familiar são dispensados de indicação georreferenciada da localização do imóvel, das áreas de preservação permanente e reserva florestal legal.

\subsubsection{Utilização de matéria-prima florestal e obrigação de reposição florestal:}

A utilização de matéria-prima florestal por empresas é submetida a controle pelo órgão ambiental, por meio do plano de suprimento sustentável e informações prestadas anualmente pelas citadas empresas. 
Assim, os recursos de matéria-prima florestal para as atividades dessas empresas devem advir de manejo florestal, realizado por plano de manejo florestal sustentável aprovado; de supressão da vegetação natural, devidamente autorizada; de florestas plantadas e outras formas de biomassa florestal, definidas em normas específicas do órgão ambiental competente.

A obrigação de reposição florestal configura-se como a compensação do volume de matéria-prima extraído de vegetação natural pelo volume de matéria-prima resultante do plantio florestal para geração de estoque ou recuperação de cobertura florestal.

Essa obrigação é imposta a todo aquele que utilizar matéria-prima florestal oriunda de supressão de vegetação natural ou detenha a autorização de supressão de vegetação natural, dela ficando isento somente quem comprovar a utilização de resíduos provenientes de:

a) atividade industrial;

b) de matéria-prima florestal oriunda de supressão vegetal autorizada para realização de benfeitoria ou uso doméstico do imóvel rural de sua origem;

c) plano de manejo florestal sustentável;

d) material não madeireiro.

Ao órgão ambiental compete a verificação da efetiva reposição florestal, por meio de um sistema de creditamento, sendo que o plantio de florestas com espécies nativas em áreas de preservação permanente e de reserva florestal legal degradadas pode gerar créditos de reposição florestal.

Finalmente, também é possível que uma lei ou ato normativo eleja determinada espécie vegetal o artigo 29, do Decreto $n^{\circ}$ 5.975, de 30 de novembro de 2006, pró́be a exploração para fins madeireiros a castanheira ("Betholetia excelsa") e a seringueira ("Hevea spp") em florestas naturais, primitivas ou regeneradas. 


\section{CAPÍTULO 2 \\ DELINEAMENTO DAS CONCESSÕES}

\subsection{Considerações sobre a concessão em sentido amplo:}

O vocábulo concessão, conforme explica Maria Sylvia Zanella Di Pietro $^{127}$, é usado no Direito Administrativo com diversos sentidos, em razão de possuir diferentes objetos, tais como a delegação de execução de serviço público ao particular, a execução de obra pública ou o simples uso de bem público, com ou sem possibilidade de exploração comercial.

A professora ${ }^{128}$ também ressalta que inexiste uniformidade de pensamento sobre uma definição do instituto da concessão, percebendo-se três linhas doutrinárias bem definidas, uma mais ampla, uma intermediária e uma restrita, tomando por critério diferenciador o fato de abarcar um maior número de objetos ou não na relação jurídica.

Na primeira escola, de origem italiana e de pouca aceitação no Brasil, ensina a doutrinadora que a concessão é conceituada como qualquer tipo de ato, unilateral ou bilateral, por meio do qual a Administração Pública outorga direitos ou poderes ao particular.

Tal concepção ampla, portanto, abarcaria num mesmo conceito as várias hipóteses de atos e contratos administrativos diferenciados pela tradição do Direito Administrativo brasileiro.

A segunda escola, intermediária, parte de uma divisão entre concessão constitutiva e concessão translativa e admite três categorias em sentido amplo, a concessão de serviço público, a concessão de obra pública e a concessão de uso de bem público.

A terceira corrente doutrinária, mais restritiva, conceitua a concessão somente como aquela modalidade pela qual a Administração Pública outorga a execução de um serviço público ao particular.

Pela maneira de entender de Odete Medauar ${ }^{129}$, a explicação do contrato de concessão deve ser feita pela exposição de suas modalidades, porém em número de quatro, ao invés de três, como adotado pela maioria dos outros doutrinadores.

Assim, para ela a concessão "se apresenta sob quatro modalidades no ordenamento brasileiro", sendo a concessão de serviço público, concessão de serviço

\footnotetext{
127 Parcerias na Administração Pública, concessão, permissão, franquia, terceirização, parceria públicoprivada e outras formas, São Paulo: Atlas, 2006. p. 83

${ }^{128}$ Direito Administrativo, São Paulo: Atlas, 2008. p. 271 - 272

${ }^{129}$ Direito Administrativo Moderno, São Paulo: Editora Revista dos Tribunais, 2001. p. 252
} 
público precedida de obra pública (ou concessão de obra pública), concessão de uso de bem público) e concessão de direito real de uso.

Para Hely Lopes Meirelles ${ }^{130}$, o conceito de concessão também é construído pela exposição das suas características básicas (bilateralidade, comutatividade, onerosidade e personalismo) e das diferentes espécies de contratos dele componentes, que, para ele, são apenas três, pois deve ser excluída a concessão de direito real de uso, nos seguintes termos:

Contrato de concessão é o ajuste pelo qual a Administração delega ao particular a execução remunerada de serviço ou de obra pública ou lhe cede o uso de um bem público, para que o explore por sua conta e risco, pelo prazo e nas condições regulamentares e contratuais. Daí a tripartição da concessão em concessão de serviço público, concessão de obra pública e concessão de uso de bem público, consubstanciadas em contrato administrativo bilateral, comutativo, remunerado e realizado intuitu personae. (itálico do original, grifo nosso)

Edmir Netto de Araújo ${ }^{131}$, partindo da explicação do significado da palavra "concessão", conclui que no conceito jurídico de concessão devem ser incluídas, basicamente, duas espécies de relações jurídicas estabelecidas pelo poder público e o particular, a outorga do uso privativo do bem público e a execução de um serviço público:

Como se vê, em qualquer caso, o sentido é o da aquiescência de alguém que detém poder ou direito sobre algo (titularidade), para a ação de outrem. Assim, o Poder Público, titular do patrimônio e dos serviços públicos, concede ou permite (ou até simplesmente autoriza) ou uso privativo de bem público por particular, ou o desempenho de serviços públicos delegáveis (pois há serviços públicos indelegáveis), a particulares ou outras entidades públicas. (negrito do original, grifo nosso)

A importância da doutrina supra transcrita reside exatamente no fato que, muito apropriadamente o doutrinador realçou o sentido do instituto concessão: ser uma concordância daquele que detém o poder de prestar um serviço público ou um direito real de transferi-los ao exercício de outra pessoa.

Este é o cerne do conceito de concessão, apesar das inúmeras utilizações equivocadas do termo, com diversos sentidos e variações entre os doutrinadores quanto a

\footnotetext{
${ }^{130}$ Direito Administrativo Brasileiro, São Paulo: Malheiros, 1998. p. 231
}

${ }^{131}$ Curso de Direito Administrativo, São Paulo: Saraiva, 2005. p. 154 
inclusão da concessão de obra pública na concessão de serviço público ou exclusão da concessão de uso de bem público do conceito de concessão.

José Cretella Júnior ${ }^{132}$, tal como Maria Sylvia Zanella Di Pietro, anotou que o vocábulo concessão "tem trazido dificuldades no campo do Direito Público" e "doutrina, a lei e a jurisprudência têm concorrido para semelhante confusão", porém:

Por outro lado, qualquer que seja a aplicação deste vocábulo - concessão - nele sempre existe um sentido comum, que é o da transferência ou outorga a terceiro de poderes, no todo ou em parte, vantagens, utilidades que pertencem ao concessionário, reservando-se, entretanto, o concedente, alguns dos direitos, vantagens ou utilidades. (itálico do original, grifo nosso)

Com efeito, o doutrinador ${ }^{133}$ posteriormente separa o conceito de concessão em dois sentidos, o lato e o técnico.

No sentido lato, a concessão pode ser conceituada como "atos que, em determinados casos concretos, constituem em favor de determinadas pessoas uma nova condição jurídica ou um novo direito subjetivo".

No sentido técnico, "preciso, concessão é transferência, temporária ou resolúvel, por uma pessoa coletiva de Direito Público, de poderes que lhe competem para outra singular ou coletiva, pública ou privada, a fim de que esta execute serviços por sua conta e risco, mas no interesse geral" (grifo nosso).

A menos que se compreenda o termo "serviços" de forma muito ampla e, em conseqüência, não como especificamente serviços públicos, o aludido doutrinador acaba por adotar uma definição jurídica de concessão que contempla apenas a concessão de serviço público, portanto a corrente doutrinária mais restrita.

Tomando-se em consideração os diferentes pensamentos expostos, o conceito de concessão pode ser construído como a relação jurídica contratual, regida pelo direito público, por meio da qual o poder público transfere ao particular o exercício de uma atividade que lhe competia realizar ou o exercício de um direito sobre bem de seu domínio.

Este conceito é amplo e considera a concessão um gênero, cujas espécies que nele podem ser abarcadas sãs as três mencionadas, sendo que a concessão de serviço público e a concessão de obra pública amoldam-se à transferência do exercício de uma

${ }^{132}$ CRETELLA JUNIOR, José. Dos Contratos Administrativos, Rio de Janeiro: Editora Forense, 2001. p. 123

${ }^{133}$ Op. cit. p. 127 
atividade que competia ao poder público realizar e a concessão de uso de bem público amolda-se ao exercício de um direito sobre bem de domínio do poder público.

Tal conceito é adequado à lição de José Cretella Júnior ${ }^{134}$, para quem “o vocábulo concessão serve para dar o gênero próximo de diversos institutos do direito administrativo que, em suas linhas gerais, apresentam um traço comum insuprimível - a transferência, pelo poder público, de algumas prerrogativas, às pessoas de direito privado.”.

Para reforço do conceito ora colocado, não é demais atentar-se ao conceito em sentido amplo construído por Maria Sylvia Zanella Di Pietro ${ }^{135}$ : “(...) contrato administrativo pelo qual a Administração confere ao particular a execução remunerada de serviço público ou de obra pública, ou lhe cede o uso de bem público, para que o explore pelo prazo e nas condições regulamentares e contratuais.” (negrito do original).

Neste contexto, considera-se que a concessão de direito real de uso é apenas uma subespécie, ou seja, espécie de concessão de uso de bem público.

Percebe-se que os conceitos de serviço público, obra pública e uso de bem público qualificam o "núcleo concessão" dos conceitos de cada uma das citadas espécies, o que é reservado para os tópicos seguintes, até para se contribuir no desvendamento da natureza jurídica da concessão florestal que, adianta-se, assemelha-se mais a uma subespécie de concessão de uso de bem público, do que à concessão de serviço público.

Feitas tais considerações iniciais, adentra-se nas classificações para as várias espécies de concessão.

\subsection{Classificações de concessão:}

No tradicional magistério de Oswaldo Aranha Bandeira de Mello ${ }^{136}$ depara-se uma primeira classificação para o gênero concessão, a concessão translativa e a concessão constitutiva de direito.

Para o doutrinador, a primeira é "ato administrativo (...) pelo qual o concedente atribui ao concessionário inalterados os poderes e deveres que lhe cabem para exercê-los e cumpri-los em seu lugar, a fim de praticar ato jurídico" (grifo nosso); e a segunda é "ato administrativo constitutivo de direito a concessão pela qual o concedente

\footnotetext{
${ }^{134}$ Tratado do Domínio Público, Rio de Janeiro: Editora Forense, 1984. p. 130

${ }^{135}$ Direito Administrativo, São Paulo: Atlas, 2008. p. 274

${ }^{136}$ Princípios Gerais de Direito Administrativo, Rio de Janeiro: Editora Forense, vol. I, 1969. p. 490-491
} 
delega ao concessionário poderes para utilizar ou explorar bem público, mas os atribui em qualidade inferior e quantidade menor do que os tem".

Em primeiro plano, relevante apontar que o doutrinador conceitua a concessão sempre como "ato administrativo", portanto manifestação unilateral de vontade, e não como contrato, bilateral, estando sua classificação neste ponto prejudicada diante do entendimento doutrinário atual, o que é verificável, por exemplo, pela lição de Maria Sylvia Zanella Di Pietro ${ }^{137}$ :

Diante do direito positivo brasileiro não há como negar a existência da concessão de uso privativo de bem público, como instituto independente da concessão de serviço público. Ambas constituem espécies do gênero concessão. Sob o aspecto formal, as duas modalidades constituem contratos administrativos sujeitos a regime jurídico publicístico. (grifo nosso)

Noutro sentido, a qualidade da classificação reside no fato de precisar seus conteúdos específicos, podendo-se pinçar o núcleo do conceito de concessão translativa como outorga de poderes, deveres, prática mesmo de atos (atividade) e de concessão constitutiva como uso, exploração de bem público.

Apercebe-se que há uma diferença de intensidade dos direitos que são objeto da outorga a terceiros pelo concedente, havendo na concessão translativa, comparativamente à concessão constitutiva, maior conteúdo, uma vez que o doutrinador anota, em relação a esta última, que o concedente reserva para si parte daquilo que transfere, pois "atribui em qualidade inferior e quantidade menor do que os tem".

Na acertada explicação de Maria Sylvia Zanella Di Pietro ${ }^{138}$, na concessão translativa o concedente passa ao concessionário um bem ou um direito que se perde pelo primeiro e se adquire pelo segundo, enquanto na concessão constitutiva o concedente detém para si um poder mais amplo enquanto atribui ao concessionário um menos amplo.

Realmente, a classificação cumpre seu objetivo de precisamente demonstrar a diferença entre duas espécies bem definidas de concessão, incluindo-se na categoria de concessão translativa a concessão de serviço público, a concessão de obra pública, a concessão patrocinada e a concessão administrativa e na categoria de concessão constitutiva a concessão de uso de bem público e sua espécie concessão de direito real de uso.

${ }^{137}$ Uso Privativo de Bem Público por Particular, São Paulo: Revista dos Tribunais, 1983. p. 85

${ }^{138}$ Op. cit., p. 272-273 
Em ambas, contudo, há um traço característico comum de reserva pelo poder concedente de alguns direitos, poderes, vantagens, o que, em verdade, decorre da natureza jurídica de contrato administrativo, ou seja, contrato disciplinado por regime jurídico de direito público, com prerrogativas à Administração sustentadas nos princípios da supremacia e da indisponibilidade do interesse público.

$\mathrm{Na}$ doutrina estrangeira, Pietro Virga ${ }^{139}$, ao analisar o denominado "uso excepcional" ("uso eccezionale") de bens demaniais ("bene demaniale") explica que ele é conferido por meio de concessão de natureza constitutiva, da seguinte forma: "Le concessioni sono atti di natura costitutiva, i quali conferiscono al privato um diritto su cosa altrui di tipo análogo ai diritti parziari disciplinati da diritto privato (ad. es. diritto di superfície per le concessioni di suolo pubblico."

Uma segunda classificação possível é a que adota como critério diferenciador o conteúdo do objeto da concessão, podendo-se dividi-la em dois grandes grupos, a concessão de serviço público em sentido amplo e concessão de uso de bem público.

Pela explanação de Edmir Netto de Araújo ${ }^{140}$, por exemplo, pode-se reforçar este entendimento:

Embora também formalizadas por contratos administrativos, as concessões de uso de bem público diferem das concessões de serviço público exatamente no objeto da relação jurídica: enquanto nesta o Estado, titular de um serviço público, resolve delegá-lo a particular ou empresa, visando melhoria, agilização dos serviços e redução de custos para o erário, naquela o Poder Público permite que um particular use e/ou explore, em seu proveito, com exclusividade, um determinado bem do domínio público, da coletividade, ou parte dele. (grifo nosso)

De forma semelhante é a doutrina de Marçal Justen Filho ${ }^{141}$, que entende que "a grande diferença entre concessão de serviço e concessão de uso reside na posição jurídica do concessionário".

Para ele, na primeira o concessionário "desempenha função pública e assume encargos próprios e típicos do Estado" e, na segunda, o “ particular não assume nenhum interesse público específico e definido, até se admitindo que lhe seja facultado valer-se do bem para satisfação exclusiva e privativa de seus interesses egoísticos”.

\footnotetext{
${ }^{139}$ Diritto Amministrativo, Milão: Giuffrè, 1983. p. 257

${ }^{140}$ Op. cit., p. 687

${ }^{141}$ Curso de Direito Administrativo, São Paulo: Saraiva, 2005. p. 726
} 
Das transcrições doutrinárias é possível verificar que, no primeiro grupo, o da concessão de serviço público em sentido amplo, são incluídas as subespécies concessão de serviço público em sentido estrito (ou concessão comum de serviço público), concessão de obra pública (ou concessão de serviço público antecedida de obra pública), concessão patrocinada, concessão administrativa e concessão de portos organizados ${ }^{142}$.

No segundo grupo, o da concessão de uso de bem público em geral, podese inserir a concessão de uso de bem público (ou concessão administrativa de uso de bem público), concessão de direito real de uso e demais concessões regidas por legislação esparsa (desde que com natureza contratual), como a concessão florestal, a concessão especial para fins de moradia, concessão de uso de águas públicas, concessão de terreno em cemitério público e concessão de áreas aeroportuárias ${ }^{143}$.

Ressalta-se, apenas, que os atos unilaterais de trespasse de serviço público ou de uso de bem público não são objeto deste estudo, motivo pelo qual não se pode, por exemplo, incluir a concessão do denominado "regime de concessão", previsto no artigo $2^{\circ}$, inciso I, do Decreto-Lei n ${ }^{\circ}$ 227, de 28 de fevereiro de 1967 (Código de Mineração), com redação alterada pela Lei no 9.314, de 14 de novembro de 1996.

Tal regime de concessão, em verdade, contempla mero ato administrativo, pois, na dicção do citado dispositivo, é configurado "quando depender de portaria de concessão do Ministro de Estado de Minas e Energia”, o que é defendido também por Digo de Figueiredo Moreira Neto ${ }^{144}$, que assim se manifesta: "A denominação, embora tradicional não é técnica, pois aqui não se trata de celebração de um contrato administrativo" (grifo nosso).

Independentemente da classificação, é possível se definir os traços semelhantes dos dois grandes universos de concessões, as de serviço público e a de uso de bem público, sendo um primeiro traço, por exemplo, a aplicação subsidiária a todas elas da Lei $n^{\circ}$ 8.666, de 21 de junho de 1993 (Lei Geral de Licitações e Contratos), quer em razão de remição nesse sentido nas leis específicas, como ocorre nas leis disciplinadoras das concessões de serviço público, quer em razão do próprio estatuto geral das licitações e contratos administrativos, no caso da concessão de uso de bem público.

\footnotetext{
${ }^{142}$ Conforme o Decreto $\mathrm{n}^{\circ}$ 6.620, de 29 de outubro de 2008, trata-se de subespécie de concessão de serviço público, com expressa previsão de submissão à Lei Geral de Concessões e Permissões de Serviços Públicos.

${ }^{143}$ Chama-se a atenção para os contratos de arrendamento de instalações portuárias, disciplinados pelo mesmo decreto que, apesar da denominação, podem ser considerados subespécie de concessão de uso de bem público.

${ }^{144}$ Curso de Direito Administrativo, Rio de Janeiro: Editora Forense, 2006. p. 456
} 
Comparando-se as duas principais espécies de concessão, a matéria encontra-se muito mais sistematizada na legislação em relação às concessões de serviço público, pela Lei $n^{\circ} 8.987$, de 13 de fevereiro de 1995 e Lei ${ }^{\circ} 11.079$, de 30 de dezembro de 2004.

Em situação diversa encontra-se a disciplina legal da concessão de uso de bem público, um dos instrumentos de outorga do uso privativo de bem público para o particular, quase sempre de forma esparsa, necessitando por isso ser sistematizada pela doutrina.

Edmir Netto de Araújo ${ }^{145}$, inclusive, aponta este fato não só para a concessão de uso de bem público, como também para os demais instrumentos de outorga do uso privativo de bem público ao particular, e conclui que "Assim, evidencia-se a importância da construção doutrinária e jurisprudencial sobre tais instrumentos jurídicos de outorga de uso privativo de bem público".

Thiago Marrara ${ }^{146}$ também ressalta que, no Brasil, tanto pela matéria não possuir acento constitucional, quanto pelo fato de todos os entes federativos gozarem de competência legislativa em Direito Administrativo, “(...) é comum que esses institutos sejam recriados a cada diploma legal, assumindo variadas significações”.

Posto isto, o objetivo deste capítulo é de fixar um roteiro para se definir a qual categoria de concessão se encaixa a concessão florestal, para isso se analisando, num primeiro momento, concisamente os traços semelhantes da disciplina jurídica das duas grandes categorias de concessões (serviço público e uso de bem público) e, em segundo lugar, as normas próprias de cada categoria.

\subsection{Semelhanças entre as concessões de serviço público e de uso de bem público:}

A primeira característica comum das concessões de serviço público e das concessões de uso de bem público é o fato de possuírem natureza jurídica contratual, o que, por si só, faz defluir uma série de outras similitudes.

Por ser contrato, é uma relação jurídica que se inicia pelo acordo de vontades de, no mínimo, duas partes, com obrigações recíprocas e determinado objeto, ou seja, como toda relação jurídica é composta pelo elemento subjetivo e pelo elemento objetivo.

\footnotetext{
${ }^{145}$ Op. cit. p. 1085

${ }^{146}$ Bens Públicos Domínio Urbano Infra-estruturas, Belo Horizonte: Editora Fórum, 2007. p. 136
} 
Trata-se, também, de contrato administrativo, ou seja, relação jurídica regida pelo direito público com um regime jurídico especial, caracterizado por elementos essenciais como "a possibilidade de o conteúdo das prestações ser alterado, durante a execução do contrato, para a satisfação das novas exigências do interesse público" e o princípio do equilíbrio financeiro do contrato, que "deve ser sempre respeitado, de tal forma que o interesse público não seja satisfeito à custa dos legítimos interesses dos particulares, nem estes possam sobrepor-se à necessária garantia do primeiro", no dizer de Diogo Freitas do Amaral ${ }^{147}$.

O conceito de contrato aqui adotado, portanto, assemelha-se aquele constante no artigo $2^{\circ}$, parágrafo único, da Lei no 8.666, de 21 de junho de 1993.

Além disso, é relação jurídica que nasce, se desenvolve em determinado prazo e se extingue, incidindo neste trajeto um conjunto de regras e princípios jurídicos próprios, de direito público, por isso sendo qualificado como um contrato administrativo.

Diogo de Figueiredo Moreira Neto ${ }^{148}$, muito apropriadamente, mesmo se referindo apenas à concessão de serviço público, relaciona como características do contrato administrativo de concessão:

a) imperatividade, qualificada como "imanente, mas apenas em potencial";

b) validade, "construída sobre a presunção de veracidade, de legalidade, de legitimidade e de licitude dos pressupostos fáticos e jurídicos sobre os quais foi estabelecida";

c) eficácia, "decorrente da presumida validade";

d) exeqüibilidade, "possibilidade de execução imediata";

e) executoriedade, "que é própria dos atos em que a Administração é parte";

f) bilateralidade, "referida nos efeitos desejados";

g) comutatividade, "equivalência das prestações recíprocas";

h) onerosidade, "existência de obrigações de valor econômico";

i) instabilidade, "tanto quanto ao conteúdo obrigacional de interesse público, quanto à própria permanência da relação contratual".

Acertada a lição do doutrinador, podendo-se alagar tais características também à concessão de uso de bem público, uma vez que, com as devidas adaptações, nela também são encontradiças.

Também, as duas principais categorias de concessões exigem, em regra, um procedimento prévio à sua celebração, de escolha da melhor parte contratante,

\footnotetext{
${ }^{147}$ Curso de Direito Administrativo, Coimbra: Almedina, 2001. p. 504

${ }^{148}$ Curso de Direito Administrativo, Rio de Janeiro: Editora Forense, 2006. p. 438-439
} 
procedimento este que deve obediência, além de outros específicos, ao princípio da igualdade.

A obrigação expressa de licitação prévia à concessão de serviço público é prevista no artigo 175, da Constituição Federal: “Artigo 175 - Incumbe ao Poder Público, na forma da lei, diretamente ou sob regime de concessão ou permissão, sempre através de licitação, a prestação de serviços públicos." (grifo nosso).

No artigo 14, da Lei nº 8.987, de 13 de fevereiro de 1995 (Lei Geral de Concessões e Permissões), nos seguintes termos:

Artigo 14 - Toda concessão de serviço público, precedida ou não da execução de obra pública, será objeto de prévia licitação, nos termos da legislação própria e com observância dos princípios da legalidade, moralidade, publicidade, igualdade, do julgamento por critérios objetivos e da vinculação ao instrumento convocatório. (grifo nosso)

No diploma legal paulista, Lei Paulista $\mathrm{n}^{\mathrm{o}}$ 7.835, de 08 de maio de 1992, regra em sentido semelhante assim dispõe:

Artigo $3^{\circ}$ - A concessão de obra e de serviço público, subordinada à existência de interesse público previamente justificado, será sempre precedida de licitação, na modalidade de concorrência. (grifo nosso)

Na própria Lei nº 8.666, de 21 de junho de 1993 (Lei Geral de Licitações e Contratos Administrativos), no artigo 124, há disposição de aplicação dela às licitações e contratos para concessão e permissão de serviços públicos, desde que não conflitante com a legislação específica.

$\mathrm{E}$, se não bastassem as disposições retro apontadas, a obrigatoriedade de licitação prévia também consta como regra geral nas leis que regem concessões de serviços públicos específicos, tais como os exemplos abaixo:

a) serviço de energia elétrica: no artigo 23, da Lei n 9.427, de 26 de dezembro de 1996, há regra de caráter amplo, no sentido que as licitações para outorga de concessões devem observar como "norma geral", a Lei no 8.666, de 21 de junho de 1993;

b) serviço de telecomunicações: no artigo $3^{\circ}$, da Lei ${ }^{\circ}$ 9.295, de 19 de julho de 1996, com redação modificada pela Lei $n^{\circ}$ 9.472, de 16 de julho de 1997, assim como o artigo 88, desta última, são claros quanto à promoção de licitação prévia à concessão de tal serviço; c) serviço de exploração de portos: no artigo $1^{\circ}, \S 2^{\circ}$, da Lei $n^{\circ} 8.630$, de 25 de fevereiro de 1993, é prevista a licitação prévia; 
c) serviço de transporte de gás natural, entre outras atividades: no artigo $3^{\circ}$, inciso I, da Lei $\mathrm{n}^{\circ} 11.909$, de 04 de março de 2009 também é prevista a licitação prévia à concessão.

Ainda, na Lei $n^{\circ} 11.079$, de 30 de dezembro de 2004 (Lei das Parcerias Público-privadas), no artigo 10, “caput”, há previsão de licitação prévia ao estabelecimento de tais espécies de concessão.

Para a concessão de uso de bem público a aplicação da Lei $n^{\circ}$ 8.666, de 21 de junho de 1993 decorre de que prevê seu artigo 2', "caput", que incluiu "concessões", entre obras, serviços, compras, alienações, permissões e locações da Administração Pública que, quando contratadas com terceiros, devem ser precedidas de licitação.

Esta licitação, por seu turno, também é regrada por um diploma legal próprio, básico, com regras genéricas aplicáveis a qualquer uma das hipóteses de outorga de serviço público ou uso de bem público em caráter privativo ao particular, como demonstrado.

Ou seja, o diploma legal da licitação e contrato administrativo constitui um núcleo comum de regras e princípios jurídicos regente das duas espécies de concessão.

Tanto na concessão de serviço público, quanto na concessão de uso de bem público, não se pode olvidar, também são exigidas outras formalidades prévias, antes mesmo da promoção da licitação, ressaltando-se:

a) a manifestação de interesse público;

b) avaliação do objeto a ser transferido (seja a atividade, seja o uso de bem);

c) autorização legislativa.

A manifestação de interesse público, a avaliação do objeto da outorga e a autorização legislativa, também terão suas peculiaridades próprias, porém, em substância, todas essas medidas prévias devem ser implementadas nas duas espécies de concessão.

Os motivos disto são explicados com bastante lógica.

Em relação à primeira providência, a exposição das razões de interesse público, serve para que a Administração Pública demonstre a conveniência e oportunidade tanto da delegação da execução de um serviço público ao particular, quanto da delegação do uso de um bem público em caráter privativo ao particular.

Portanto, há discricionariedade na decisão de delegação, por isso é obrigatório que a motivação do ato seja expressa na medida prévia, que se demonstre o melhor atendimento do interesse público, pois, em razão mesmo do princípio da finalidade, é condição de validade da decisão a sujeição ao interesse público. 
Deve-se notar que, na própria Lei Paulista $n^{\circ} 7.835$, de 08 de maio de 1992, diploma legal das concessões e permissões de serviço público no Estado de São Paulo, a dicção do artigo $3^{\circ}$ é de que "a concessão de obra e de serviço público, subordinada à existência de interesse público previamente justificado" (grifo nosso), demonstrando-se, assim, a necessidade da exposição prévia de todas as justificativas para a realização da concessão.

E, de forma mais explícita, no artigo $5^{\circ}$, da Lei $\mathrm{n}^{\circ} 8.987$, de 13 de fevereiro de 1995 (Lei Geral de Concessões e Permissões), a dicção é “o poder concedente, publicará, previamente ao edital de licitação, ato justificando a conveniência da outorga de concessão ou permissão, caracterizando seu objeto, área e prazo" (grifo nosso).

Além dessas disposições, tem-se também na Lei $\mathrm{n}^{\circ} 11.079$, de 30 de dezembro de 2004 (Lei das Parcerias Público-privadas), no seu artigo 10, inciso I, alínea a), previsão quanto à necessidade de autorização da autoridade competente, fundamentada em estudo técnico que demonstre, entre outras coisas, "a conveniência e oportunidade da contratação, mediante identificação das razões que justifiquem a opção pela forma de parceria público-privada". Esta autorização, no âmbito das parcerias público-privadas, é expressão da citada regra geral de manifestação de interesse público para todas as hipóteses de concessão.

A propósito da finalidade de tal manifestação prévia de interesse público, Maria Sylvia Zanella Di Pietro ${ }^{149}$ bem anota:

Quando a lei exige manifestação quanto ao mérito, tem-se que entender que aí se incluem vários aspectos, como o da razoabilidade e proporcionalidade, que exigem adequação entre meios e fins, exame da relação custo-benefício, utilidade para o interesse público, economicidade, entre outros.

Apesar de a anotação referir-se especificamente às parcerias públicoprivadas é inegável que também se aplica às demais espécies de concessão, sejam de serviço público ou mesmo uso de bem público.

Nas parcerias público-privadas, Mauricio Portugal Ribeiro e Lucas Navarro Prado ${ }^{150}$, explicam que tal manifestação de conveniência e oportunidade da contratação se faz pela demonstração "da finalidade do projeto, dos seus impactos no

\footnotetext{
${ }^{149}$ Direito Administrativo, São Paulo: Atlas, 2008. p. 300

150 Comentários à Lei de PPP Parceria Público-Privada, fundamentos econômico-jurídicos, São Paulo: Malheiros, 2007. p. 259
} 
desenvolvimento econômico regional e/ou nacional, e análise comparativa do projeto com opções funcionalmente equivalentes".

Da mesma forma, a manifestação de interesse público para as demais formas de concessão de serviço público, ou mesmo para uso de bem público, guardadas as devidas proporções e peculiaridades, podem perseguir os mesmos objetivos.

A avaliação prévia, com nuanças específicas para cada uma das categorias de concessão, pois baseadas em critérios e parâmetros definidores diversos, sempre deve ocorrer para proteção do patrimônio público e, por que não dizer, do patrimônio do particular concessionário.

Constatam-se as peculiaridades da avaliação prévia para cada uma das espécies de concessão, por exemplo, no fato da "precificação" do serviço público ser diferente da "precificação" do uso privativo de bem público, sendo, no primeiro caso, verificados critérios atinentes à tarifa, enquanto, no segundo caso, são verificados critérios do valor de mercado do uso de áreas e finalidades semelhantes.

A avaliação prévia protege o patrimônio público e privado, na medida em que visa impossibilitar o enriquecimento sem causa quer seja do particular, a quem se outorgou atividade ou uso, quer seja ao poder público.

É inegável que é decisão de suma importância a referente ao cálculo da contraprestação devida pelo particular que, na condição de concessionário, também deverá ter garantida a percepção do lucro, se prestando a isso também a medida de avaliação prévia.

Mais uma vez, pode-se constatar que no artigo $6^{\circ}$, da Lei Paulista $n^{\circ}$ 7.835, de 08 de maio de 1992 (Lei Paulista de Concessões e Permissões) há disposição quanto à obrigação do poder concedente disponibilizar aos interessados os estudos sobre a viabilidade do serviço ou obra pública objetos da concessão.

Ora, se tais estudos objetivam a demonstração da viabilidade da outorga do serviço ou obra pública, também evidenciam aquilo que o poder concedente deve auferir pela concessão.

Obviamente, a forma de exposição ora adotada é bastante simplista principalmente em relação à concessão de serviço público, que possui regramento complexo para a fixação de tarifa e manutenção do equilíbrio econômico-financeiro do contrato, por exemplo. 
Quanto à autorização legislativa, conceitualmente o que se busca é a manifestação de vontade do povo representado no Poder Legislativo, concordante com a delegação pretendida pelo Poder Executivo.

Interessante notar que o ato legislativo, além do conteúdo autorizador, também pode servir de veículo para o atendimento da primeira providência retro comentada, a manifestação de interesse público.

Ou seja, a aquiescência do povo representado se expressa pelo ato legislativo produzido.

Todavia, a indispensabilidade da autorização legislativa prévia às concessões é matéria bastante discutida e controvertida.

$\mathrm{Na}$ concessão de serviço público, a autorização legislativa prévia é determinada no artigo $2^{\circ}$, da Lei $n^{\circ} 9.074$, de 07 de julho de 1995, que modificou a Lei ${ }^{\circ}$ 8.987, de 13 de fevereiro de 1995 (Lei Geral de Concessões e Permissões), sendo dispensada nos casos de saneamento básico, limpeza urbana e nos referidos na Constituição Federal, nas Constituições Estaduais e Leis Orgânicas do Distrito Federal e Municípios.

Na Lei Paulista $n^{\circ} 7.835$, de 08 de maio de 1992, não há dispositivo específico que imponha a obrigatoriedade de autorização legislativa prévia à licitação de concessão de serviço público.

A exigência de autorização legislativa prévia para concessão de serviço público, prevista no artigo $2^{\circ}$, da Lei $\mathrm{n}^{\circ}$ 9.074, de 07 de julho de 1995, é criticada duramente por Maria Sylvia Zanella Di Pietro ${ }^{151}$ baseada nos argumentos abaixo sintetizados:

a) a autorização legislativa configura uma interferência do Poder Legislativo na prática de ato típico do Poder Executivo, inerente ao exercício de sua função administrativa, por isso, exigiria disposição constitucional expressa, tais como as hipóteses de controle prévio de um Poder sobre o outro, previstas na Constituição Federal;

b) no artigo 175, da Constituição Federal, dispositivo constitucional base para o regime de concessões e permissões de serviço público, a previsão é de execução de serviço público de forma direta ou por meio de concessão e permissão, sem qualquer outra exigência;

c) em relação à concessão de serviços públicos para os quais o dispositivo legal dispensa autorização legislativa prévia, ocorreria a invasão da competência dos Estados e

${ }^{151}$ Parcerias na Administração Pública, Concessão, Permissão, Franquia, Terceirização, Parceria PúblicoPrivada e outras Formas, São Paulo: Atlas, 2006. p. 89 - 90 
Municípios, pois as Constituições Estaduais e Leis Orgânicas Municipais é que devem disciplinar tal matéria.

Na mesma linha é o entendimento de Marcos Juruena Vilela Souto ${ }^{152}$, para quem a "delegação do serviço público mediante concessão configura ato de gestão, que, na sistemática constitucional da separação de Poderes, cabe, principiologicamente, ao Poder Executivo”, além da lei federal não poder “(...) descer a minúcias que interfiram na autonomia municipal e estadual".

$\mathrm{Na}$ concessão de uso de bem público, também há discussão sobre a obrigatoriedade de autorização legislativa prévia à licitação, havendo a corrente doutrinária favorável e outra contrária.

A primeira corrente doutrinária, no sentido da obrigatoriedade de autorização legislativa é aquela que se baseia numa interpretação ampla do termo “alienação", constante no artigo 17, inciso I, da Lei n 8.666, de 21 de junho de 1993 (Lei Geral de Licitações e Contratos Administrativos), de bens imóveis da Administração Direta, autárquica e fundacional, dispensada em casos específicos previstos na mesma lei.

Pertence a esta corrente doutrinária Marçal Justen Filho ${ }^{153}$ que defende que, no citado artigo 17, “A expressão "alienação" é utilizada numa acepção ampla", compreendendo a "alienação no sentido próprio e técnico" e "outros institutos que possibilitam a outro sujeito o uso e a fruição parcial ou temporária de bens e de direitos de titularidade da Administração Pública.", pois, apesar de reconhecer que "essas figuras não se enquadram no conceito de 'alienação', há similitude nos "interesses em jogo" e "uma equivalência quanto ao tipo de relacionamento entre a Administração e os particulares". (grifo nosso).

$\mathrm{Na}$ corrente doutrinária contrária, que defende a não obrigatoriedade de autorização legislativa prévia à licitação para concessão de uso de bem público, encontrase Floriano Peixoto de Azevedo Marques Neto ${ }^{154}$, cuja compreensão do termo "alienação" restringe-se à transferência de domínio do bem, por qualquer negócio jurídico admitido, apartando-se as hipóteses de outorga de direitos especiais (privativos) de uso.

Edmir Netto de Araújo ${ }^{155}$ também defende que termo "alienação" do citado artigo 17 deve ser somente aquele definido no artigo $6^{\circ}$, inciso IV, da mesma Lei $\mathrm{n}^{\circ}$ 8.666, de 21 de junho de 1993, portanto apenas a transferência "do direito de propriedade

\footnotetext{
${ }^{152}$ Direito Administrativo das Concessões, Rio de Janeiro: Lumen Juris, 2004. p, 48

${ }^{153}$ Comentários à Lei de Licitações e Contratos Administrativos, São Paulo: Dialética, 2008. p. 212

${ }^{154}$ Op. cit., p. 358

${ }^{155}$ Curso de Direito Administrativo, São Paulo:Saraiva, 2005. p. 499
} 
(eliminando eventuais dúvidas sobre alienação da posse-concessão, permissão)" (itálico do original, grifo nosso), mas lembra que é exigida a autorização legislativa pelo artigo 19, incisos IV e V, da Constituição do Estado de São Paulo ${ }^{156}$.

Ao analisar o tema alienação de bens públicos imóveis, Diogenes Gasparini $^{157}$ ressalta que será legítima se observado também o requisito autorização legislativa, porém, informa que, no âmbito da União não é exigida em razão do artigo 23, da Lei $n^{\circ}$ 9.636, de 15 de maio de 1998.

Tal dispositivo legal declara ser suficiente para tal finalidade um ato do Presidente da República, precedido de parecer da Secretaria de Patrimônio da União SPU, podendo tal competência ser delegada ao Ministro de Estado da Fazenda, permitida até a subdelegação, sendo, portanto, tal regra aplicável somente à União, concluindo o doutrinador que, “outras entidades da Federação, a cada caso, há de ser precedida de autorização legislativa, segundo, a exemplo de outras, prescreve a Constituição de São Paulo (art. 19, IV)".

Neste particular, ainda, reforça-se que é muito comum as Leis Orgânicas de Municípios atribuírem ao Poder Legislativo a competência de autorizar previamente, por meio de lei, a transferência de domínio e também de poderes a ele inerentes, de bens públicos a particulares.

No artigo 49, inciso XVII, da Constituição Federal, é prevista a competência exclusiva do Congresso Nacional de aprovar, previamente, a alienação ou concessão de terras públicas com área superior a dois mil e quinhentos hectares.

Portanto, comparando-se o texto da Constituição Federal com o da Constituição Estadual e muitas Leis Orgânicas Municipais, há uma diferença de intensidade, pois a regra da primeira estabelece um limite de área em que a autorização legislativa deve ser exigida (acima de dois mil e quinhentos hectares) e as regras estaduais e municipais são mais amplas, não estabelecendo tal limite.

Portanto, a sistemática geral é no sentido mesmo da necessidade de autorização legislativa prévia à licitação de concessão de uso de bem público,

\footnotetext{
${ }^{156}$ O conteúdo dos citados dispositivos da Constituição do Estado de São Paulo são: “Artigo 19 - Compete à Assembléia Legislativa, com a sanção do Governador, dispor sobre todas as matérias de competência do Estado, ressalvadas as especificadas no art. 20, e especialmente sobre: (...)IV - autorização para a alienação de bens imóveis do Estado ou a cessão de direitos reais a eles relativos, bem como o recebimento, pelo Estado, de doações com encargo, não se considerando como tal a simples destinação específica do bem; V autorização para cessão ou para concessão de uso de bens imóveis do Estado para particulares, dispensado o consentimento nos casos de permissão e autorização de uso, outorgada a título precário, para atendimento de sua destinação específica;

${ }^{157}$ Direito Administrativo, São Paulo: Saraiva, 2008. p. 917
} 
consubstanciada na razão já abordada da concordância do povo representado com a restrição do uso que o mesmo faz do bem público em benefício do particular.

Contudo, vislumbra-se que tal regra poderá ser questionada quanto à constitucionalidade, pelo desrespeito à cláusula de separação dos poderes $\left(\operatorname{artigo} 2^{\circ}\right.$, da Constituição Federal), pois, também, não foi estabelecido no texto constitucional uma regra específica que permita a interferência de um poder sobre o outro em ato de gestão de transferência de serviço público ou uso de bem público, em conformidade com o que pensam de Maria Sylvia Zanella Di Pietro e Marcos Juruena Vilela Souto.

Não se deve olvidar também, que se exige lei para a desafetação de bens públicos de uso comum do povo e bens públicos de uso especial, sendo que tal lei de desafetação também pode servir de veículo à autorização da posterior concessão de uso do bem público ao particular, em caráter privativo e de forma onerosa.

\subsection{Diferenças entre as concessões de serviço público e de uso de bem público:}

Analisadas as principais semelhanças das espécies básicas de concessão de serviço público e concessão de uso de bem público, neste tópico adentra-se nas principais diferenças, de forma bastante sucinta, com a finalidade de se contribuir para a comparação, ao final, com a concessão florestal.

Neste tópico também não se imerge profundamente nas várias subespécies de concessão de serviço público e de concessão de uso de bem público, pois a comparação genérica é suficiente para o atingimento do objetivo final.

O traçado da comparação das principais diferenças segue um eixo que se baseia na exploração dos princípios jurídicos próprios e conjunto de leis aplicáveis, às partes contratantes e terceiros, ao objeto da relação contratual, aos direitos e deveres do concessionário, entre outros aspectos.

Confrontando-se a concessão de serviço público com a concessão de uso de bem público, chega-se à conclusão que a principiologia jurídica que incide sobre elas é muito semelhante e, por que não dizer, praticamente idêntica, pois os princípios da supremacia e indisponibilidade do interesse público são os que se encontram nas bases de tais relações jurídicas.

Além de tais princípios, toda a principiologia específica da licitação também é comum para as duas espécies de concessão. 
Portanto, a diferenciação entre elas é conseqüência do objeto específico de cada uma, dando-se maior nota ao da concessão de serviço público.

Em razão do objeto da concessão de serviço público é que incidem princípios jurídicos diversos daqueles incidentes sobre a concessão de uso de bem público, princípios jurídicos aqueles que também compõem o regime jurídico dos serviços públicos.

Neste diapasão, o primeiro princípio que se pode afirmar que é aplicável somente à concessão de serviço público é o da continuidade do serviço público, expresso no fato da impossibilidade de tal atividade parar, uma vez que as necessidades sociais por ele atendidas também não cessam.

A incidência desse princípio ocasiona particularidades na concessão de serviço público, não observadas na concessão de uso de bem público, sendo exemplos mais marcantes os privilégios que a Administração Pública titular do serviço público detém, tais como a reversão, a encampação, o uso da estrutura do concessionário para que a atividade não seja interrompida.

Além de tal característica própria, decorre de tal princípio da continuidade do serviço público também a existência de prazos contratuais mais rigorosos, a adoção da teoria da imprevisão na recomposição do equilíbrio econômico-financeiro do contrato e a não aplicação da cláusula de exceção do contrato não adimplido ("exceptio non adimpleti contractus") na concessão de serviço público, não se verificando o mesmo na concessão de uso de bem público.

Outro princípio exclusivo da concessão de serviço público é o da modicidade de tarifas, que decorre do princípio da generalidade (ou igualdade de usuários).

Se este último princípio significa a busca do atendimento das necessidades do maior número possível de beneficiários, sem discriminações, o primeiro visa efetivá-lo, pois em função dele é que os serviços públicos devem ser remunerados com preços módicos, que permitam o acesso do maior número possível de usuários, pois, caso contrário, se forem elevados, restringirão o almejado acesso universal ao serviço público.

O princípio da mutabilidade de regime jurídico também é outro que se aplica somente a concessão de serviço público, pois significa que a Administração Pública poderá modificar o regime jurídico de execução do serviço público a fim de adaptá-lo ao interesse público.

Com base em tal princípio que aspectos da concessão de serviço público poderão ser alterados, para a melhor prestação do serviço público. 
Quanto ao conjunto de normas jurídicas e bloco de legislação aplicável a cada uma das espécies de concessão, tem-se que na concessão de serviço público incide, em caráter geral, a Lei $n^{\circ}$ 8.987, de 13 de fevereiro de 1995 (Lei Geral de Concessões e Permissões), alterada pela Lei $n^{\circ}$ 9.074, de 07 de julho de 1995, a Lei no 11.079, de 30 de dezembro de 2004 (Lei das Parcerias Público-Privadas), além daquelas que dispõem sobre serviços públicos específicos como telecomunicações, energia elétrica, transporte e outras atividades com gás natural, entre outros.

Na concessão de uso de bem público, entretanto, não se encontra um bloco de legislação tão organizado quanto ao aplicável à concessão de serviço público. Trata-se de matéria disciplinada por legislação esparsa, de cada ente federativo, sendo que as normas básicas encontram-se mesmo na Lei $n^{\text {o }}$ 8.666, de 21 de junho de 1993 e alterações posteriores.

Contudo, para a subespécie concessão de direito real de uso e para concessão de uso específicas, tais como a concessão especial para fins de moradia, concessão de uso de águas públicas, concessão de áreas aeroportuárias e concessão florestal, existem diplomas legais específicos, a saber, respectivamente: Decreto-Lei $\mathrm{n}^{\circ}$ 271, de 28 de fevereiro de 1967, Medida Provisória $n^{\circ}$ 2.220, de 04 de setembro de 2001, Decreto $\mathrm{n}^{\mathrm{o}}$ 24.643, de 10 de julho de 1934 (Código das Águas), Lei no 7.565, de 19 de dezembro de 1986 (Código Brasileiro de Aeronáutica) e Lei nº 11.284, de 02 de março de 2006 (Lei Geral de Gestão das Florestas Públicas).

Em que pese o fato da concessão de serviço público e da concessão de uso de bem público serem formadas por duas partes contratantes, na primeira é possível a produção de efeitos perante um terceiro que não compõe a relação jurídica principal, o usuário do serviço público.

Maria Sylvia Zanella Di Pietro ${ }^{158}$ denomina tal peculiaridade de "efeitos trilaterais da concessão" e explica que é uma das características da concessão de serviço público a produção de efeitos perante os usuários do serviço concedido.

Os citados efeitos, assim, decorrem da própria postura do usuário perante o serviço público, que independe do fato dele ser prestado diretamente pelo poder público ou por um concessionário, tanto que a própria Lei $\mathrm{n}^{\mathrm{o}}$ 8.987, de 13 de fevereiro de 1995, prevê os direitos do usuário: à prestação do serviço adequado, à fiscalização sobre a prestação do serviço, à informação para defesa de direitos individuais ou coletivos, à

${ }^{158}$ Op. cit., p. 111 
modicidade de tarifas, à indenização por danos causados na prestação do serviço, entre outros.

Reitera-se, as peculiaridades da concessão de serviço público decorrem do próprio objeto, o serviço público, que é submetido a um regramento jurídico peculiar, o que não ocorre em relação à concessão de uso de bem público.

Se não bastasse tal especificidade, o objeto da concessão de uso de bem público é normalmente menos complexo do que o serviço público, nisto se explicando a menor complexidade jurídica, em regra, da concessão de uso de bem público.

Aspectos como a modicidade da tarifa, a forma de execução do serviço público, o respeito aos direitos dos usuários, sem se analisar as espécies mais complexas de parcerias público-privadas, por exemplo, demonstram a maior complexidade jurídica das várias subespécies de concessão de serviço público.

Todavia, em algumas subespécies de concessão de uso de bem público, tais como a concessão de áreas aeroportuárias, a concessão de uso de águas públicas, o uso peculiar de tais bens jurídicos também exigem uma certa complexidade que distancia as concessões aplicáveis às suas outorgas daquela espécie clássica de concessão de uso de bem público pura e simples.

O mesmo ocorre em relação aos direitos e deveres do concessionário e demais peculiaridades, podendo-se pinçar como as principais, que distancia a concessão de serviço púbico da concessão de uso de bem público:

a) existência de remuneração ao concessionário por meio de tarifa paga pelos usuários;

b) possibilidade de outras fontes de remuneração ao concessionário;

c) a existência de prazos mais dilatados como forma de garantir a amortização dos investimentos do concessionário, que costumam ser de grande vulto e de demorada recuperação por causa também do princípio da modicidade da tarifa;

d) existência de formas de extinção com denominação própria, tais como a encampação, a caducidade;

e) necessidade de comprovação do interesse público e indenização ao concessionário, na hipótese de encampação, tanto dos bens reversíveis, quanto de outros prejuízos;

f) necessidade também de autorização legislativa para a encampação, cuja constitucionalidade é questionável;

g) necessidade de processo administrativo, com oferta de ampla defesa, para comprovação de inadimplemento contratual causado pelo concessionário, antecedido de prazo para 
correção das falhas, no caso de caducidade, não cabendo indenização, com exceção dos bens reversíveis;

h) obrigação do concessionário ajuizar ação judicial para a rescisão do contrato, na hipótese de descumprimento do contrato por culpa do concedente, devendo continuar prestando o serviço público até decisão final;

i) existência, em favor do concedente, do poder de intervenção, poder de encampação, poder de decretação da caducidade, poder de usar compulsoriamente a estrutura humana e material do concessionário;

j) ocorrência de reversão, em que os bens do concessionário aplicados ao serviço público concedido são transferidos ao poder concedente, uma vez extinta a concessão, com a devida indenização;

1) possibilidade de constituição de sociedade de propósito específico, para melhor gestão do serviço público concedido;

m) possibilidade de obtenção de financiamento, por parte do concessionário, garantido por direitos emergentes da concessão, desde que não inviabilize a prestação do serviço público.

Na concessão de uso de bem público, o concessionário não é remunerado por um usuário, pois ele próprio é quem usa em caráter privativo o bem público concedido, assim não podendo se falar em tarifa ou qualquer outra forma de remuneração.

A onerosidade do contrato, na verdade, decorre do pagamento da contraprestação que o concessionário deve despender em favor do concedente pelo uso do citado bem.

Os prazos também são mais curtos, devendo observar a regra do artigo 57, da Lei $\mathrm{n}^{\mathrm{o}}$ 8.666, de 21 de junho de 1993 (Lei Geral de Licitações e Contratos Administrativos) e alterações posteriores, motivados pela razão da duração contratual ter que ficar adstrita à vigência dos créditos orçamentários, portanto medida protetora das finanças públicas, mesmo não havendo dispêndio de receitas públicas em favor do concessionário pelo poder concedente.

As formas de extinção da concessão de uso de bem público são, em regra, algumas daquelas constantes no artigo 78 e 79, da Lei nº 8.666, de 21 de junho de 1993 (Lei Geral de Licitações e Contratos Administrativos) e alterações posteriores, podendo ser determinada por ato unilateral da Administração, amigável, desde que atendido o interesse público e judicial, nos casos previstos em lei.

Para todas as hipóteses é obrigatória a promoção de processo administrativo, conforme artigo 78, parágrafo único, da citada Lei, assegurada a ampla 
defesa e contraditório ao concessionário, como a qualquer contratado da Administração Pública.

Quanto às hipóteses previstas nos incisos do aludido artigo 78, da Lei, que se enquadram na concessão de uso de bem público, pode-se realçar as seguintes:

a) não cumprimento ou cumprimento irregular de cláusulas contratuais, especificações, projetos e prazos (incisos I e II);

b) subcontratação total ou parcial do objeto, associação do contrato com outrem, cessão ou transferência, total ou parcial, fusão, cisão ou incorporação, desde que não admitidas pelo edital ou termo contratual (inciso VI);

c) desatendimento das determinações regulares da autoridade que acompanha e fiscaliza a execução do contrato, assim como a de seus superiores (inciso VII);

d) cometimento reiterado de faltas (inciso VIII);

e) decretação de falência ou instauração de insolvência civil (inciso IX);

f) dissolução da sociedade ou falecimento do contratado (inciso X);

g) alteração social ou modificação da finalidade ou estrutura da empresa que acarrete prejuízo a execução do contrato (inciso XI);

h) razões de interesse público, relevantes, de amplo conhecimento, justificadas nos autos de processo administrativo pela autoridade superior (inciso XII);

i) ocorrência de caso fortuito ou de força maior impeditivas da execução do contrato, desde que comprovadas;

j) descumprimento do artigo $7^{\circ}$, inciso XXXIII, da Constituição Federal, ou seja, utilização de menores em trabalho noturno, perigoso ou insalubre (inciso XVIII).

É possível constatar-se que, apesar de denominações diferenciadas, muitas das hipóteses de extinção da concessão de serviço público assemelham-se às hipóteses de extinção da concessão de uso de bem público.

Feitas tais considerações, adentra-se no tópico final, da demonstração que a concessão florestal é subespécie de concessão de uso de bem público, e não de concessão de serviço público, o que também é objeto, com maior profundidade, no capítulo 5 deste trabalho. 


\subsection{Breve comparação da concessão florestal com as demais modalidades:}

Da exposição das principais semelhanças e diferenças existentes entre a concessão de serviço público e a concessão de uso de bem público, afere-se que a concessão florestal pertence ao grupo desta última modalidade.

A primeira razão que justificam tal entendimento é o fato de que, na concessão florestal, também se estabelece uma relação jurídica bilateral, entre o poder concedente e o concessionário.

Entretanto, na concessão florestal, tal como ocorre na concessão de serviço público, terceiros estranhos a tal relação jurídica também podem sofrer os seus efeitos jurídicos, como, por exemplo, comunidades locais que habitem uma determinada unidade de manejo submetida à concessão.

Tal influência da concessão florestal, contudo, não se aproxima daquela sentida pelo usuário de serviço público, pois tal comunidade local não é usuária da atividade de manejo florestal sustentável conduzida pelo concessionário.

Em verdade, antecedendo a isto tudo, tem-se a constatação que a atividade de condução do manejo florestal sustentável não é serviço público, mas simples uso peculiar, especialíssimo, da floresta pública, tal como ocorre na exploração de outros bens ambientais, como minas, água, areia.

Trata-se de uso privativo de bem público que comporta não só a ocupação (fixação da infra-estrutura para realização do manejo florestal sustentável) e transformação, como também o poder de disposição de uma parte da matéria, exemplificado por Maria Sylvia Zanella Di Pietro ${ }^{159}$ em situações como “aproveitamento de águas públicas ou extração de areia".

$\mathrm{Na}$ esteira desta constatação decorrem importantes conseqüências, como a inaplicabilidade, à concessão florestal, da principiologia que incide sobre a concessão de serviço público, tal como o princípio da continuidade ou da modicidade de tarifas, até porque inexistem tarifas em tal subespécie de concessão.

O poder concedente, na concessão florestal, também não despende outras formas de receitas públicas para remunerar o concessionário, podendo ocorrer apenas a adoção de um sistema de bonificação, consistente em descontos no preço público que remunera a exploração sustentável da floresta, quando atendidos parâmetros de desempenho socioambiental, além das obrigações legais e contratuais, conforme previsão

${ }^{159}$ Op. cit. p. 653 
do artigo 46, da Lei Geral de Gestão de Florestas Públicas (assunto este tratado especificamente no subitem 5.5.5.3 adiante).

A concessão de tais descontos no pagamento do preço público remuneratório do manejo florestal sustentável não se confunde com outras formas de remuneração do concessionário de serviço público.

Quanto aos prazos da concessão florestal, guarda-se certa semelhança com a concessão de serviço público, sendo também longuíssimos, nisto destoando da concessão de uso de bem público, pela razão também de se garantir a amortização dos investimentos do concessionário.

Contudo, a necessidade de amortização dos investimentos do concessionário florestal prende-se muito mais a razões ambientais, do que a necessidade de prestação do serviço público e a demora de recuperação em razão de tarifas módicas.

Conforme adiante se aborda com maior completude, no subitem 5.5.4, as razões ambientais que exigem prazos longos de concessão florestal referem-se basicamente aos ciclos de produção e recuperação da floresta, principalmente quando em ecossistemas tropicais.

Na concessão florestal, tal como ocorre com a concessão de serviço público, também há formas de extinção com denominação própria, porém, isto não é suficiente para se concluir que a primeira é espécie da segunda.

Tais formas de extinção estão previstas no artigo 44, da Lei n ${ }^{\circ} 11.284$, de 02 de março de 2006 (Lei Geral de Gestão de Florestas Públicas), consistindo em esgotamento do prazo contratual, rescisão, anulação, falência ou extinção do concessionário e falecimento ou incapacidade do titular, no caso de empresa individual e desistência e devolução, por opção do concessionário, do objeto da concessão.

Apesar de tais formas serem denominadas de forma diversa, são, em síntese, aquelas dispostas de modo genérico na Lei nº 8.666, de 21 de junho de 1993 (Lei Geral de Licitações e Contratos Administrativos).

$\mathrm{Na}$ concessão florestal também se previu a possibilidade de bens reversíveis, de obtenção de financiamento pelo concessionário garantido por direitos emergentes da concessão e de criação de sociedade de propósito específico, institutos próprios da concessão de serviço público.

Porém, não se pode concluir que tais especificidades da concessão florestal confere-lhe natureza jurídica de concessão de serviço público, uma vez que tais 
institutos servem para garantia da preservação da sustentabilidade e não em razão do princípio da continuidade do serviço público, como dito por razões ambientais.

O concessionário florestal, assim como ocorre o concessionário de serviço público, caso pretenda extinguir a concessão em razão do descumprimento contratual por culpa do poder concedente, também deverá ajuizar ação judicial, conforme artigo 47, da Lei n 11.284, de 02 de março de 2006 (Lei Geral de Gestão de Florestas Públicas).

Porém, tal como nas outras similitudes com a concessão de serviço público, a continuidade da manutenção do contrato por parte do concessionário florestal não visa atender o princípio da continuidade do serviço público, mas os princípios da precaução e do desenvolvimento sustentável.

Finalmente, não se aplica na concessão florestal os poderes de intervenção, de encampação e de decretação da caducidade, uma vez que tais hipóteses de extinção da concessão são específicas da concessão de serviço público.

Desta forma, resta inegável que a concessão florestal é uma subespécie de concessão de uso de bem público.

Também, pode ser classificada como uma espécie de concessão constitutiva, pois o poder público transfere ao particular o direito de usar e explorar a floresta pública, direito este que é menor, em qualidade e quantidade, do que os poderes que o poder público exerce sobre tal bem.

A concessão florestal, além disso, garante ao poder concedente da titularidade da floresta pública e a definição de seu melhor uso, conforme plano técnico de manejo florestal sustentável.

Cumprido o objetivo deste capítulo, apenas anota-se que todas as considerações genéricas que o compõem são detalhas e comprovadas no capítulo 5 , do presente trabalho. 


\section{CAPÍTULO 3 \\ FLORESTAS PÚBLICAS NO MUNDO}

\subsection{Anotações sobre a gestão de florestas públicas no mundo:}

Segundo Maria Teresa Cristina de Deus ${ }^{160}$, a principal floresta do mundo em extensão é a Floresta Boreal, também denominada de Floresta de Coníferas, que ocupa uma área de mais de 6 (seis) bilhões de hectares ou quase 12 (doze) milhões de quilômetros quadrados, o que equivale a $24 \%$ (vinte e cinco por cento) da superfície do globo terrestre.

Tal floresta está situada no extremo norte da Europa, Ásia e América do Norte, nos territórios de países desenvolvidos, motivo pelo qual não há tanta pressão para sua conservação como há com as florestas tropicais que, em sua grande maioria, estão localizadas nos países subdesenvolvidos.

Países como o Canadá e a Rússia (por este último chamada de "taiga"), possuem aproximadamente $70 \%$ (setenta por cento) da Floresta Boreal e na porção dela existente no território do Estado do Alaska, dos Estados Unidos da América, se encontra a maior floresta nacional norte-americana, de natureza jurídica pública, com uma extensão de 69 (sessenta e nove) mil quilômetros quadrados ${ }^{161}$.

Esta é a "Floresta Nacional Tongass" ("Tongass National Forest”), criada por ato do presidente Theodore Roosevelt Jr., em 10 de setembro de 1907, que possui as características de unidade de conservação e é administrada pelo Serviço Florestal NorteAmericano ("US Forest Service"), órgão do Ministério da Agricultura daquele país.

Em relação às florestas tropicais, são os países da América Latina, África, Oceania e Ásia seus maiores detentores, sendo que no Brasil está localizada a maior parte da Floresta Amazônica, cuja função ambiental é de ser "reguladora climática, tanto da região tropical propriamente dita, quanto da parte sul da América do Norte”, sendo que "até mesmo os países do ocidente da Europa acabam sendo beneficiados do ponto de vista climático", segundo explica Maria Teresa Cristina de Deus ${ }^{162}$.

Além da Floresta Amazônica, o Brasil também se destaca por possuir a Mata Atlântica e outros biomas de interesse nacional, tal como a Serra do Mar, o Pantanal Mato-Grossense e a Zona Costeira, todos incluídos no $§ 4^{\circ}$, do artigo 225, da Constituição

\footnotetext{
${ }^{160}$ Op. cit., p. 5

${ }^{161}$ Informação disponível em http://en.wikipedia.org/wiki/Tongass_National_Forest, acesso em 19 jul. 2009.

${ }^{162}$ Loc. cit.
} 
Federal e denominados "patrimônio nacional”, que, para Maria Sylvia Zanella Di Pietro ${ }^{163}$, é expressão que designa a idéia de "coisa incorpórea (...) cuja proteção ultrapassa a esfera dos direitos individuais para entrar na categoria de interesses públicos (...) sujeito a normas especiais de proteção (...).”.

Andréa Struchel e Élson Roney Servilha ${ }^{164}$ anotam que o Brasil conta com "a segunda maior área florestal do planeta, com 470 (quatrocentos e setenta) milhões de hectares, a floresta amazônica e a mata atlântica sofrem com o predadorismo nacional e internacional (...)".

Luís Paulo Sirvinskas ${ }^{165}$ informa que a Floresta Amazônica possui uma área aproximada de 3,5 (três e meio) milhões de quilômetros quadrados e a Amazônia Legal, conforme artigo $1^{\circ}, \S 2^{\circ}$, inciso VI, do Código Florestal, compreende os Estados do Acre, Pará, Amazonas, Roraima, Rondônia, Amapá, Mato Grosso e as regiões situadas ao norte do paralelo $13^{\circ} \mathrm{S}$, dos Estados de Tocantins e Goiás e ao oeste o meridiano $44^{\circ} \mathrm{W}$, do Estado do Maranhão.

Desta forma, trata-se da "segunda maior floresta do mundo, com 554 milhões de hectares, o que representa $14 \%$ da área mundial, a qual ocupa $64,3 \%$ do território nacional (FAO, 2005)”, segundo Amália Maria Goldberg Godoy ${ }^{166}$.

Ainda segundo tal doutrinadora ${ }^{167}$, no Brasil "cerca de $50 \%$ das florestas se encontram em áreas públicas" e:

No caso da Amazônia, por exemplo, 75\% estão em áreas públicas. Desse total, as Unidades de Conservação e Terras Indígenas, ou seja, as áreas protegidas juntas, representam $30 \%$ do total e outros $45 \%$ são de terras públicas de uso ainda não definido ou desprotegida (LBA, 2005).

Na Exposição de Motivos no 14 /MMA/GM/2005, de 16 de fevereiro de 2005, que acompanhou o Projeto de Lei n ${ }^{\circ}$ 4.776/2005, a então Ministra de Estado do Meio Ambiente, Marina Silva, explanou de forma semelhante:

Com a maior diversidade de espécies e ecossistemas do planeta, habitada por uma das mais diversas e amplas

163 __ Polícia do meio ambiente, Revista Forense, vol. 317, Rio de Janeiro: Forense, 1992. p. $179-187$

${ }^{164}$ O Direito, as Leis e a Gestão das Florestas, in Revista de Direito Ambiental, ano 12, n. 46, p. 17 40, abr.-jun./2007

${ }^{165}$ Op. cit., p. 378

${ }^{166}$ A gestão sustentável e a concessão das florestas públicas. Revista de Economia Contemporânea, Rio de Janeiro, 10(3), p. 631 - 654, set./dez. 2006

${ }^{167}$ Loc. cit. 
concentrações de povos e culturas indígenas, as florestas brasileiras protegem a circulação de $20 \%$ da água doce disponível no mundo.

3.2 Afora a grande extensão e diversidade de florestas, $\underline{\mathbf{o}}$ Brasil é o maior produtor e consumidor mundial de produtos florestais tropicais. (...)

3.5 A Amazônia brasileira, responsável por mais de $90 \%$ da produção florestal de áreas naturais do Brasil, apresenta, segundo estimativas, apenas $24 \%$ do território reclamado como área privada e $29 \%$ com áreas legalmente protegidas, incluindo as Unidades de Conservação e Terras Indígenas. Neste cenário fundiário, restam $47 \%$ da superfície ocupada por terras públicas ou devolutas, com cobertura predominantemente florestal e sobre as quais o exercício da atividade do Estado é ainda incipiente. (grifo nosso)

Das informações retro coligidas, a extensão de florestas públicas, somente na Floresta Amazônia brasileira, é de quase um milhão e setecentos e cinquienta mil quilômetros quadrados, o que, por si só, sinaliza a dificuldade de sua gestão.

Entre as principais experiências de gestão de florestas públicas estrangeiras, destacam-se como positivas as de países como o Canadá e Austrália, conforme informação de Vicente Gomes da Silva ${ }^{168}$, Procurador Federal do IBAMA, que também apontou, ao contrário, como experiências negativas as dos países africanos, como Costa do Marfim, Camarões, República Centro Africana e República Democrática do Congo e países asiáticos, como Indonésia e Filipinas, "fracassaram com projetos semelhantes".

Eder Zanetti ${ }^{169}$ informa que no Canadá, desde a década de 1990, foram criadas onze florestas-modelo com o objetivo básico de servir de "transição do manejo convencional para a produção florestal sustentável e a conservação dos recursos naturais". Tais florestas-modelo tem sido uma solução valiosa também para a gestão das florestas de domínio público e daquelas existentes em áreas de comunidades indígenas.

Explica o doutrinador que o programa de florestas-modelo iniciado no Canadá foi estruturado em forma de rede, para envolver outros países como Estados Unidos da América, México, Rússia, "estando em fase final de associação a Malásia, Japão, Chile e Argentina, havendo ainda mais 25 países que já acenam com a possibilidade de sua participação em um futuro próximo".

Porém, no continente asiático, asseverou que a Malásia "pode ser citada como experiência um pouco mais exitosa neste sentido, pelo fato de que o manejo da

168 Aspectos Legais sobre a Concessão de Florestas Públicas, in Fórum de Direito Urbano e Ambiental FDUA, Belo Horizonte, ano 5, n. 26, p. 3153-3156, mar./abr. 2006

${ }^{169}$ Meio Ambiente, Setor Florestal, Curitiba: Juruá, 2009. p. 53 
floresta naquele país é de longo prazo - em torno de 70 anos - e a legislação é rigorosíssima em relação ao descumprimento de regras de proteção das florestas”.

O mesmo doutrinador, em relação aos países da América Latina, ressaltou que no Peru, "onde se fez grandes investimentos públicos nos anos 1960 e 1970, as florestas continuam sendo fortemente devastadas".

Stela Maria Ramos de Melo ${ }^{170}$, ao contrário, expressa visão mais otimista, informando que, no Peru, "o Ministério do Meio Ambiente é assessorado pelos Estados Unidos, uma vez que este país possui facilidade de certificação de produtos florestais. É cobrada patente pelo uso da floresta, tanto para as terras públicas, como para as privadas".

Ela também informa que na Bolívia vigora a Lei $n^{\circ} 1.700 / 97$, que dispõe sobre a concessão empresarial, concessão para associações sociais e locais e, quanto às terras indígenas, "os empresários contratam diretamente como os índios, que possuem assessoria do governo", sendo que o processo de concessão, "ao contrário do Brasil, é aberto às empresas internacionais". Ainda, os prazos de concessão são de até quarenta anos, com possibilidade de renovação por igual período, e as auditorias são qüinqüenais e somente sobre as empresas que não possuam certificação dos produtos florestais.

No Paraguai, informa Moisés Villalba González e Carlos José Caetano Bacha $^{171}$, toda terra com cobertura florestal, "seja de propriedade estatal, seja privada, está sujeita ao regime da Lei $n^{\circ} 422$, que data de 16 de novembro de 1973 e que regula a utilização e conservação das florestas e bosques do país”.

Pelo relato de tais doutrinadores, o "Servicio Forestal Nacional (SFN)", do Ministério da Agricultura, é o órgão estatal gestor, em cujas atribuições se inclui a formulação da política florestal, administração das "reservas estatais" e outorga de "licenças e concessões para explorar bosques do Estado".

Ainda, segundo eles, as florestas públicas do Paraguai são classificadas como "florestas protetoras" e seu uso é outorgado ao particular por meio de "permissões e concessões”, sendo que “(...) uma permissão permite a exploração de até $1000 \mathrm{~m}^{3}$ por ano de madeira de espécies selecionadas pertencentes a lotes de até 100 ha.”. Quanto a áreas de até 2000 ha (dois mil hectares), é permitida a concessão a "pequenas indústrias e cooperativas" por um período de até cinco anos. Tais permissões e concessões não

\footnotetext{
${ }^{170}$ Concessão de Florestas Púbicas, in Biblioteca Digital Fórum de Direito Urbano e Ambiental - FDUA, Belo Horizonte, ano 7, n. 40, jul./ago. 2008. Disponível em: HTTP://www.editoraforum.com.br/bid/bidConteudoShow.aspx?idConteudo=54702. Acesso em: 16 julho 2009.

${ }^{171}$ As Políticas Florestais do Brasil e Paraguai, in Teoria e Evidência Econômica, Passo Fundo, v. 14, n. 28, p. 37-56, maio 2007.
} 
dependem de licitação e são outorgadas diretamente pelo "Servicio Forestal Nacional". Para áreas maiores, de até 10.000 ha (dez mil hectares), pode ser adotada concessão de caráter contratual e antecedida de licitação, por período de até oito anos, com possibilidade de renovação por mais cinco anos, somente para indústrias. Tanto as concessões contratuais ou não, quanto as permissões, são intransferíveis.

Adentrando no continente europeu, tem-se que na França, conforme relata Jacqueline Morand-Deviller ${ }^{172}$, professora da Universidade de Paris I (PantheónSorbonne), apesar das florestas fazerem parte tradicionalmente do domínio privado, são submetidas às normas de direito público, pois: "Beaucoup de forêst, en effet, sont à fa fois affectées à l'usage dos public et à une fonction de loisir et de maintien de équilibres naturels s'apparentant à une mission de service public.”.

A administração das florestas está a cargo do "Office National des Forêts" (ONF), assim descrito por Jacqueline Morand-Deviller ${ }^{173}$ :

(...) établissement public qualifié d'EPIC par la loi qui a pour mission "la mise em valeur de la forêt française' (...) Créé em 1966, em lieu et place de l'administration des eaux et forêts, l'ONF est um EPIC placé sous la cotutelle des ministères de l'Agriculture et l'Environnement. Il gere 12 millions d'hectares de forêts et d'espaces naturels pour le compte de l'État et des collectivités publiques, dont 4,4 millions de forêts em métropole et 7,6 millions de foret tropicale d'outre-mer.

Nara Maria Esteves Fonseca Gonçalez, Christian Dugas de la Boissonny e Joaquim Carlos Gonçalez ${ }^{174}$, confirmam que as florestas francesas são divididas em três categorias: as do Estado ("forêts domaniales"), as da coletividade pública ("forêts départamentales ou communales) e as particulares ("forêts privées"), sendo que as primeiras correspondem a " $12 \%$ do total e as das coletividades públicas, a aproximadamente 18\%." e "os 70\% restantes correspondem às florestas particulares".

Segundo tais doutrinadores, as duas primeiras categorias submetem-se ao regime florestal do Estado, que é responsável por uma política de reflorestamento intensa que aumento a média francesa metropolitana para "30 hectares de floresta por pessoa", enquanto a "média européia é de 12 hectares de florestas por habitante".

\footnotetext{
${ }^{172}$ Cours de Droit Administratif des Biens, Paris: Montcherestien, $3^{\mathrm{a}}$ ed. , 2003. p. 55

${ }^{173}$ Loc. cit.

${ }^{174}$ Contribuição da legislação florestal francesa para a legislação brasileira, Brasília a. 43, no 169, jan./mar. 2006. p. 265-276.
} 
O Serviço Nacional de Florestas (ONF) é conceituado como um “estabelecimento público de caráter industrial e comercial” e é encarregado da gestão das florestas do Estado e das coletividades públicas, possuindo dezenove diretorias regionais na França metropolitana e quatro em além-mar.

Entretanto, o sistema condutor da política florestal é composto também pelos seguintes órgãos, todos subordinados ao Ministério da Agricultura francês:

a) Serviço de Inventário Florestal Nacional e Fundo Florestal Nacional, para financiar operações de reflorestamento;

b) Serviços Regionais de Manejo Florestal (SRMF);

c) Centros Regionais de Propriedade Florestal (CRPF), com competência para orientar a produção florestal e de controlar a gestão das florestas particulares.

Denota-se que há uma bipartição de órgãos administrativos para gestão das florestas públicas e particulares. As primeiras, desde a reforma na administração pública francesa, em 1965, são de competência do Serviço Nacional de Florestas e as segundas dos Centros Regionais de Propriedade Florestal.

Segundo Nara Maria Esteves Fonseca Gonçalez, Christian Dugas de la Boissonny e Joaquim Carlos Gonçalez ${ }^{175}$, as florestas públicas “cobrem $28 \%$ da superfície da França" e "são incontestavelmente melhores quando se trata de assegurar funções de interesse geral, como proteção contra a erosão, conservação de dunas nos litorais e lazer nas florestas".

O estatuto peculiar ao qual estão tais florestas subordinadas possibilita regras de manejo "para um período de 15 a 20 anos", "fixa objetivos e programas de ação (cortes e trabalhos), garantindo a indispensável continuidade da gestão florestal”.

$\mathrm{Na}$ Alemanha, Eder Zanetti ${ }^{176}$ informa que $46 \%$ (quarenta e seis por cento) das florestas é privada, 20\% (vinte por cento) é distrital e 34\% (trinta e quatro por cento) é pública, sendo estas últimas pertencentes ao Estado alemão que as explora com fins econômicos.

O Estado alemão, segundo tal doutrinador, investe maciçamente na certificação do patrimônio florestal e nos usos múltiplos das florestas.

Italo Magnani ${ }^{177}$ explica que "le aree per ragioni naturalistiche ed ecologiche in Italia sono divise in parchi nazionali e in riserve naturali integrali". As

\footnotetext{
175 Loc. cit.

${ }^{176}$ Op. cit. p. 38

${ }^{177}$ Beni Pubblici, Problemi teorici e di gestione. Milão: Franco Angeli Editore, 1974. p. 183
} 
"riserve naturali integrali", por sua vez, são subespécies de "riserve naturali generali", que, juntamente com as "riserve naturali particolari” compõem as "riserve naturali'.

Assim, as reservas naturais são compostas pelas reservas naturais integrais e reservas naturais orientadas ("riserve naturali orientate").

As reservas naturais integrais têm por objetivo a proteção e conservação de modo absoluto do meio ambiente, sendo nelas permitida a entrada humana para estudos, pesquisas científicas e por razões administrativas.

As reservas naturais orientadas são instituídas com o objetivo de orientar a evolução da natureza.

Ou seja, as reservas naturais integrais são muito semelhantes às Unidades de Proteção Integral brasileiras, previstas no artigo $8^{\circ}$, da Lei $n^{\circ} 9.985$, de 18 de julho de 2000.

Conclui-se, nessa vereda, que na Itália há uma gama de espécies de reservas naturais, com diferentes funções ambientais, tal como ocorre no Brasil com as Unidades de Conservação que formam um verdadeiro sistema disciplinado pela citada lei, a Lei do Sistema Nacional de Unidades de Conservação.

A natureza jurídica dos parques nacionais italianos, conforme lição de Italo Magnani ${ }^{178}$, é de "entidades de zoneamento" (“enti di zona”), conceituados da seguinte forma:

Gli "enti di zona" sono infatti quegli enti pubblici funzionali i quali pongono in essere no un'attivitá comune a determinati enti locali ma un'attività istituzionalmente própria, incidente su interesse locali. Ora gli enti di zona nascono come enti per l'esecuzione di opere pubbliche o per la gestione di pubblici servizi. Gli interessi pubblici affidati al parco hanno normalmente un contenuto diverso; sono cioè interessi alla conservazione del território ed al godimento di questo parte della colletività.

Nos referidos parques nacionais, explica o doutrinador ${ }^{179}$, é possível a emissão de autorização de corte por suas administrações, mas com posterior concordância das demais autoridades administrativas ambientais, sendo o que ele denomina de “(...) funzione aggiuntiva ed um ulteriore controllo sull'uso del bosco", de atividades de lazer, construções, a depender do parque.

${ }_{179}^{178}$ Op. cit., p. 201

${ }^{179}$ Op. cit., p. 203 
Ao lado dos parques nacionais, na Itália também existem as florestas públicas estatais e comunais, denominadas "foreste demaniali statali" e "foreste demaniali delle regioni”, que, conforme Italo Magnani ${ }^{180}$, “che il demanio nazionale risponde ad esigenze nazionali, mentre il demanio regionale assolve instanze di interesse locale".

Indispensável anotar que, no direito administrativo italiano, as florestas são bens públicos que pertencem ao "demanio naturale", cujo significado se encontra no magistério de Pietro Virga ${ }^{181}$, nos seguintes moldes:

a) demanio naturale: costituito da quei Beni demaniali, che siano tal per loro natura, independentemente dalla destinazioni ad essi data dall'amministrazione. (...) Per tali Beni la demanialità è in re ipsa, inerisce alla loro stessa natura, independentemente da una qualsiasi attività o opera della pubblica amministrazione.

Os bens do "demanio", segundo o mesmo autor, admitem o quatro espécies de uso pelos particulares: o uso geral, o uso particular, o uso especial e o uso excepcional, este último por meio de concessão, que possui natureza jurídica de ato administrativo, conforme doutrina de Pietro Virga ${ }^{182}$ : “(...) L'uso eccezionale del bene demaniale è accordato in forza di um ato di concessione (...)" (grifo nosso).

Na Espanha, leciona Ramon Parada ${ }^{183}$, o sistema florestal foi inaugurado pelas “Ordenanzas de Montes”, do Ministro Javier de Burgos, aprovadas por Real Decreto de 22 de dezembro de 1833, que "suponen, como se ha dicho, la implantación em nuestro país del sistema forestal francés, pero con uma permisividad destructiva para los montes de los particulares que será catastrófica para nuestra riqueza forestal.”.

O citado sistema florestal francês da época, segundo Ramon Parada, se constituía como uma administração moderna, segundo o modelo napoleônico, com clássicas instâncias central e periféricas, corpo de funcionários e escolas de formação de engenheiros florestais.

A antiga legislação, contudo, foi derrogada pela "Ley de Montes de mayo de 1863", lei esta de vigência muito breve, mas que foi regulamentada pelo Real Decreto de 17 de maio de 1865, mantendo, segundo Ramon Parada ${ }^{184}$, o mesmo sistema jurídico de intervenção mínima do Estado nas florestas privadas, sendo que aquelas contíguas às

\footnotetext{
${ }^{180}$ Op. cit., p. 230

${ }^{181}$ Dirito Amministrativo, I principi. Milão: Giuffrè editore, 1983. p. 248

182 Op. cit. , p. 256

183 Derecho Administrativo III, Bienes públicos Derecho Urbanístico, Madrid: Marcial Pons, Ediciones Jurídicas y Sociales S.A., 2000. p. 209

${ }^{184}$ Op. cit. , p. 211
} 
florestas públicas ainda podiam colocar-se sob defesa e custódia da Administração florestal, pagando proporcionalmente os gastos que produzissem.

Em relação à nova legislação, o doutrinador acentua:

"Mas lo que realmente ocupa y preocupa al legislador de 1863 es salvar de la privatización, y precisamente para que no caigan en el incontrolado sistema de libertad próprio de los montes de los particulares, determinados montes públicos del Estado y de los pueblos, (...)”.

Tal realidade é finalizada em 8 de junho de 1957, com a edição da "Ley de Montes”, com regulamento aprovado por Decreto de 22 de fevereiro de 1962, pois tal legislação, ensina Ramon Parada ${ }^{185}$, "aseguraban los instrumentos de uma política de fuerte intervención administrativa y no solo sobre los montes públicos, sino também sobre los de particulares, fundamentalmente en matéria de repoblación, iniciada ya con la Ley de 10 de marzo de 1941, que creó el Patrimônio Forestal del Estado".

As categorias de florestas não formam um sistema uniforme, sendo que a principal divisão é aquela semelhante ao sistema francês e italiano, a divisão entre as florestas públicas e florestas privadas.

Neste sentido, na organização do sistema florestal espanhol, a maioria das florestas públicas são administradas pelas comunidades autônomas ou entes locais, sendo que as florestas públicas "afectadas a una Escuela de Montes (para la investigación o la enseñanza) pueden ser considerados, sen duda, em aplicación de los conceptos generales sobre el dominio público y al margen de la legislación forestal, como bienes de dominio público o demaniales".

As florestas na Espanha consideradas com maior grau submissão a um regime jurídico de direito público devem ser, obrigatoriamente, de propriedade de um ente público, ser declaradas de utilidade pública e, por ato ministerial, fazer parte do Catálogo de Utilidade Pública. Sobre tais florestas recai um regime jurídico exorbitante do regime privado, que reconhece determinadas prerrogativas para a Administração para a proteção da posse e propriedade.

Assevera Ramon Parada ${ }^{186}$ que para as florestas do Estado e consorciadas, "se ajustan a las normas estabelecidas en la Ley del Patrimonio Forestal y subsidiariamente, a las de contratación administrativa (art. 37 de la Ley de Montes)" e as florestas pertencentes a entidades locais, “deben aprovechar sus montes com subordinación

${ }_{186}^{185}$ Op. cit., p. 213

${ }^{186}$ Op. cit. , p. 224 
em lo técnico-facultativo, incluida la fijación de precios mínimos de los productos, a lo que disponga la Administración forestal, y em lo económico, a lo establezca la legislación de régimen local sobre administración de patrimonio y sobre contratación.”.

O sistema florestal espanhol, compreende-se dos indicativos retro arrostados, assemelha-se ao sistema francês e italiano, com florestas públicas de caráter nacional e regional submetidas a regime de utilização pelo particular, além dos parques e espaços naturais protegidos divididos em diferentes categorias de reservas ("Parques, Reservas Naturales, Monumentos Naturales, Paisages Protegidos").

A experiência do Canadá para gestão das florestas públicas, onde "94\% das florestas (...) são de propriedade da Coroa", pode ser considerada referencial, pois, conforme leciona Stela Maria Ramos de Melo ${ }^{187}$, foi implementada por meio de um eficiente instrumento, o "Canada Forest Accord (CFA)", "acordo, em que os interessados concordam em implantar o planejamento de gestão de florestas, nele estando consagrados, expressamente, os princípios de gestão florestal sustentável.”.

O primeiro CFA foi realizado em 1992, por "uma coligação governamental (federal e provincial) e não-governamental (proprietários privados, empresas, associações industriais e florestais e grupos indígenas)" e, no CFA de 2003, subscrito por sessenta e cinco signatários, agrupando oito grandes temas, a saber:

(...) gestão baseada em ecossistemas, comunidade florestal sustentável, direitos e participação dos povos aborígenes, benefício dos produtos florestais, conhecimento e inovação para a competitividade e sustentabilidade, a floresta urbana e participação social na sustentabilidade, woodlots $^{188}$ privados, contribuição para a sustentabilidade e elaboração de relatórios e responsabilização."

O "Forest Stewardship Council - FSC"189 é uma entidade não governamental, cuja sede está localizada na cidade de Bonn, na Alemanha, e com escritórios regionais em mais de cinqüenta países, que se dedica a promoção do manejo florestal responsável, conceituado como aquele que segue princípios e critérios que conciliam as salvaguardas ecológicas com os benefícios sociais e viabilidade econômica.

\footnotetext{
${ }^{187}$ Loc. cit.

${ }^{188}$ O "woodlots" pode ser conceituado como pequena área de floresta usada para exploração de produtos florestais.

${ }^{189}$ A página eletrônica da referida entidade na rede mundial de computadores é http://www.fsc.org.
} 
Edna Cardozo Dias ${ }^{190}$ informa que os princípios de manejo florestal do FSC podem ser resumidos da seguinte forma:

a) o manejo florestal deve respeitar todas as leis aplicáveis ao país onde se operam os tratados internacionais e acordos assinados por este país e obedecer a todos os princípios e critérios do FSC;

b) as posses de longo prazo e os direitos de uso da terra e dos recursos florestais devem ser claramente definidos, documentados e legalmente estabelecidos;

c) os direitos legais e costumeiros dos povos indígenas de possuir, usar e manejar suas terras, territórios e recursos devem ser reconhecidos e respeitados;

d) as atividades de manejo florestal devem manter ou ampliar, a longo prazo, o bem estar econômico e social dos trabalhadores florestais e das comunidades locais;

e) as atividades de manejo florestal devem incentivar o uso eficiente e otimizado dos múltiplos produtores e serviços da floresta para assegurar a viabilidade econômica e uma grande quantidade de benefícios ambientais e sociais;

f) o manejo florestal deve conservar a diversidade ecológica e seus valores associados, os recursos hídricos, os solos, os ecossistemas e paisagens frágeis e singulares, para manter as funções ecológicas e integridade das florestas;

g) um plano de manejo apropriado à escala e intensidade das operações deve ser escrito, implementado e atualizado, sendo que os objetivos de longo prazo de manejo florestal e os meios para atingi-los devem ser claramente definidos;

h) o monitoramento deve ser conduzido levando em conta a escala e a intensidade do manejo florestal, para que sejam avaliadas as condições da floresta, o rendimento dos produtos florestais, as atividades de manejo e seus impactos ambientais e sociais;

i) as atividades de manejo de florestas de alto valor de conservação devem manter ou incrementar os atributos que definem estas florestas, devendo as decisões a respeito de tais florestas sempre ser consideradas no contexto de uma abordagem de precaução.

Os princípios do FSC retro analisados demonstram que o manejo florestal sustentável deve ser também socialmente responsável, o que, conforme se demonstra no tópico seguinte, inspirou a construção do sistema de princípios e regras de gestão das florestas públicas brasileiras, com cardial importância às comunidades locais.

\footnotetext{
${ }^{190}$ Gestão de florestas públicas. Biblioteca Digital Fórum de Direito Urbano e Ambiental - FDUA, Belo $\begin{array}{lllll}\text { Horizonte, ano } 5, \quad \text { n. } 29, & \text { set./out. } & 2006 . & \text { Disponível }\end{array}$ em:<http://www.editoraforum.com.br/bid/bidConteudoShow.aspx?idConteudo=37937>. Acesso em: 16 julho 2009.
} 


\subsection{Antecedentes e marco regulatório da gestão de florestas públicas brasileiras:}

No tópico 1.3 deste trabalho, em que se analisou a evolução histórica da tutela legal do patrimônio florestal, foi citado que o Código Florestal de 1934 (Decreto n ${ }^{\circ}$ 23.793, de 23 de janeiro de 1934) dispôs regras sobre a exploração de florestas do domínio público.

E, realmente, na Seção II, do antigo Código Florestal, composta pelos artigos 36 a 47, o assunto foi disciplinado de forma detalhada para a época, inaugurando determinados conceitos e formas de gestão que foram adotadas na lei atual que disciplina a matéria, objeto da análise no presente trabalho.

Primeiramente, o Código Florestal de 1934 conceituou como públicas somente as florestas de rendimento que eram suscetíveis à "exploração industrial intensiva", sempre mediante concorrência pública.

Como medida antecedente à exploração da floresta pública, impunha o artigo 37, do antigo Código Florestal, a demarcação da área pelo poder público, competindo ao órgão ambiental da época também determinar os contornos da exploração, tais como as variedades de essências florestais sujeitas ao corte, o diâmetro de tais indivíduos arbóreos sujeitos a corte ("a um metro e meio $(1,5)$ de altura do colo da raiz", na dicção do artigo 38) e os produtos e subprodutos que poderiam ser retirados da floresta.

Quanto às normas de contratação, previa o artigo 39, do Código Florestal de 1934, que a concorrência pública deveria anteceder a concessão florestal, devendo nos editais da licitação ser declaradas as obrigações impostas aos licitantes, tais como os prazos dos contratos, o início de sua execução, o preço do arrendamento e modo de seu pagamento, além das cláusulas técnicas elaboradas pela autoridade florestal daquele tempo.

O prazo do contrato não podia exceder a 10 (dez) anos, podendo, porém, ser prorrogado a juízo do governo, quando presentes algumas razões de interesse público, tais como "quando os contratantes se obrigarem a inverter novos capitais que permitam ampliar os serviços, instalando maquinismos aperfeiçoados, melhorando as vias de comunicação existentes e abrindo novas, utilizando os cursos e quedas d'água como força motriz, transformando em subprodutos os refugos não utilizados na indústria principal, ou a conceder outras compensações de interesse público." (artigo 39, §2º do Código Florestal de 1934). 
Nesta hipótese, o poder concedente poderia aditar o contrato original para constar os novos capitais que seriam aplicados, as espécies, mecanismos para aquisição de outros serviços, melhoramentos, ressalvados "os interesse nacionais".

$\mathrm{Na}$ concessão florestal daquela época era permitida a transferência dos contratos a terceiros, desde que o poder público reconhecesse a idoneidade do mesmo (artigo 39, §4º do Código Florestal de 1934).

No artigo 40, eram dispostas hipóteses de rescisão do contrato, por parte da Administração Pública, quando houvesse atraso no início da sua execução, fossem descumpridas suas obrigações, especialmente quanto ao replantio. Doutro lado, a rescisão por parte do particular, o artigo 41 estabelecia que deveria ser provada a impossibilidade de transporte dos produtos e a deficiência de madeiras ou outros produtos florestais, de forma a não permitir a exploração em larga escala, de forma a compensar as despesas. Tais hipóteses de rescisão, conforme o artigo 42, não geravam direito à indenização.

Um certo traço de sustentabilidade na exploração da floresta, que, porém, não pode ser qualificado como o moderno manejo florestal sustentável, pode ser vislumbrado nos artigos 43, 44 e 45, do Código Florestal de 1934, cujos conteúdos eram os seguintes:

Art. 43. Quando a exploração consistir apenas na colheita de fructos, sementes, cascas, folhas, seiva e cera, os contractantes procederão de modo a não comprometter, por qualquer forma, a vida e o desenvolvimento natural dos vencimentos de que forem extrahidos.

Art. 44. Quando a exploração tiver por fim o aproveitamento industrial do lenho e determinadas essencias, que, por sua grande abundancia no local, possam ser abatidas sem inconveniencia para as florestas, terá lugar o corte sob a fiscalização da autoridade competente, afim de que só recaia em arvores adultas, convenientemente situadas, e com as dimensões a que se refere $\mathrm{o}$ art. 38, attendidas as determinações deste código, especialmente quanto ao replantio e á defesa das paizagens e bellezas naturaes.

Art. 45. O corte das arvores e a colheita dos productos nas florestas de dominio público, far-se-ão em estações apropriadas e de accôrdo com a boa technica florestal. (grifo nosso)

As preocupações constantes nos dispositivos legais do antigo Código Florestal supra transcritos, podem ser caracterizadas da seguinte forma:

a) a retirada de produtos florestais (frutos, sementes, cascas, folhas, seiva e cera) deveria respeitar a capacidade de produção, o desenvolvimento natural das fontes de tais produtos; 
b) o corte de árvores deveria obedecer a boa técnica e se realizar sob a supervisão do órgão florestal da época, podendo ser objeto de corte somente árvores adultas e com determinadas dimensões;

c) tanto a retirada dos produtos florestais, quanto o corte das árvores, deveriam ser realizados em épocas apropriadas e conforme a boa técnica de manejo florestal daquele tempo.

No conjunto de regras aplicáveis a exploração das antigas florestas públicas de rendimento, também se incluiu a obrigação do concessionário reflorestá-las "sistemática e progressivamente, com preferência de espécies de crescimento rápido e de valor industrial reconhecido", conforme dicção do artigo 46, do Código Florestal de 1934.

Neste tema, por fim, o artigo 47 previa que as florestas de rendimento do domínio estadual e municipal, quando "exploradas administrativamente", eram equiparadas às do domínio particular. Provavelmente, tal regra significava que a gestão direta de florestas pelos Estados e Municípios, chamada de administrativa, deveria se submeter ao mesmo regime jurídico restritivo aplicável às particulares pelo órgão ambiental federal daquele tempo.

Na sucessão legislativa da matéria, especialmente no Código Florestal de 1965 (Lei $\mathrm{n}^{\circ} 4.771$, de 15 de setembro de 1965) e alterações posteriores, o tema não foi mais diretamente disciplinado, até a edição da Lei n ${ }^{\circ} 11.284$, de 02 de março de 2006, atual marco regulatório da matéria, regulamentada posteriormente pelo Decreto $\mathrm{n}^{\circ} 6.603$, de 20 de março de 2007.

Doutro lado, é inegável que o referido Código Florestal, juntamente com a Lei $n^{\circ}$ 6.938, de 31 de agosto de 1981 (Lei da Política Nacional do Meio Ambiente) e a Lei n 9.985 , de 18 de julho de 2000 (Lei do Sistema Nacional de Unidades de Conservação), formavam o arcabouço legal da gestão e proteção florestal brasileira, porém sem um instrumento normativo específico para regulamentar o uso específico das florestas públicas que não se amoldassem àqueles espaços territoriais especialmente protegidos das citadas leis.

Na Exposição de Motivos no 14/MMA/GM, de 16 de fevereiro de 2005, que acompanhou o projeto de lei que originou a Lei Geral de Gestão das Florestas Públicas, constou informação no sentido que o manejo de florestas públicas, no período anterior à nova lei, era praticado pela aprovação de planos de manejo florestal posteriores a obtenção, pelos particulares, da posse e arrendamento de terras públicas. 
Na doutrina, Moisés Villalba González e Carlos José Caetano Bacha, confirmam tal informação, demonstrando, ainda, que as licenças para exploração de florestas públicas, anteriormente ao novo marco regulatório, eram concedidas a título precário e experimental:

Em 02/03/2006 foi promulgada a Lei $\mathrm{n}^{\circ} 11.284$, que dispõe sobre a gestão de florestas públicas para a produção sustentável. (...) Até então, apenas áreas públicas na forma de florestas nacionais podiam, sob licença, ser exploradas pela iniciativa privada e por prazo não compatível com o uso de técnicas de impacto reduzido. Essa nova lei poderá ampliar a exploração privada de florestas públicas, pois até 2005 essas autorizações foram apenas de caráter experimental. (grifo nosso)

Assim, apesar da existência da citada legislação, das licenças experimentais para manejo florestal em terras públicas cedidas ao uso de particulares e da regulamentação do uso em unidades de conservação, inexistia no país um instrumento legal específico para disciplina da gestão dessas florestas, tal como ocorria com outros bens ambientais, como a água, os minerais, o espaço aéreo etc.

Na década de 1970, o antigo Instituto Brasileiro de Desenvolvimento Florestal - IBDF, juntamente com o Programa das Nações Unidas para Desenvolvimento PNUD e Organização das Nações Unidas para Agricultura e Alimentação - FAO iniciaram pesquisas sobre manejo na Floresta Nacional de Tapajós visando verificar a viabilidade de concessões florestais e criar um sistema nacional de florestas públicas.

Em que pese o fato das terras indígenas e unidades de conservação possuíssem regramento jurídico específico, era indispensável a implantação de uma lei para regular o uso das demais florestas existentes em áreas sob o domínio público.

Com isso, o Ministério do Meio Ambiente e o Instituto Brasileiro do Meio Ambiente e Recursos Naturais Renováveis - IBAMA desenvolveram estudos que desaguaram no projeto de lei registrado sob o $\mathrm{n}^{\mathrm{o}} 4.776$, de 16 de fevereiro de 2005, na Câmara dos Deputados (e $n^{\circ}$ 62, de 12 de julho de 2005, no Senado Federal) que fez nascer a Lei $n^{\circ}$ 11.284, de 02 de março de 2006 (Lei Geral de Gestão das Florestas Públicas), marco regulatório da gestão das florestas públicas brasileiras.

A necessidade e relevância dessa pode ser aferida pelo que noticiou o Instituto de Pesquisa Ambiental da Amazônia - IPAM ${ }^{191}$, em 2008, sobre a divulgação do dado, pelo Sistema Florestal Brasileiro, que “duzentos e onze milhões de hectares, ou 25\%

${ }^{191}$ Disponível em: <http://www.ipam.org.br/mais/noticiasitem/id/169> Acesso em: 17 jul. 2009 
do território nacional, é o tamanho do total de florestas públicas cadastradas no Brasil” e que "a maior parte das florestas públicas, cerca de 94\%, está na Região Norte”. (grifo nosso).

Urgente, assim, a instituição de um marco regulatório dirigido a preservação e exploração sustentável desse imenso patrimônio do poder público, dado também o papel estratégico que as florestas têm desempenhado na atualidade.

No novo marco regulatório, além propriamente da disciplina da gestão de florestas públicas para produção sustentável, foi instituído o Serviço Florestal Brasileiro SFB, na estrutura do Ministério do Meio Ambiente, criado o Fundo Nacional de Desenvolvimento Florestal - FNDF, o Cadastro Nacional de Florestas Públicas e o Plano Anual de Outorga Florestal - PAOF, este último instrumento por meio do qual a União Federal descreverá todas as florestas públicas passíveis de concessão florestal.

O decreto regulamentador da Lei Geral de Gestão das Florestas Públicas é o Decreto $n^{\circ}$ 6.063, de 20 de março de 2007, que detalhou as disposições a respeito do Cadastro Nacional das Florestas Públicas, da destinação de florestas públicas às comunidades locais, do Plano Anual de Outorga Florestal, do licenciamento ambiental e das regras para a licitação e gestão do contrato administrativo de concessão florestal.

Conclui-se, deste modo, que o Estado brasileiro optou pela denominada gestão indireta, expressa pela outorga, ao particular, do direito de explorar tal floresta pública por meio de um plano de manejo sustentável aprovado e fiscalizado, ao invés da alienação da floresta ao particular ou a exploração direta.

As razões de tal opção, desnudadas na exposição de motivos que acompanhou o projeto de lei que originou a Lei Geral de Gestão das Florestas Públicas, consistem no entendimento que, em relação à transferência de propriedade das florestas públicas aos particulares, além de não gerar benefícios econômicos, sociais e ambientais, esbarraria na limitação do artigo 49, inciso XVII, da Constituição Federal, que impõe a autorização do Congresso Nacional para áreas públicas com área acima de 2.500 ha (dois mil e quinhentos hectares).

Em relação à segunda hipótese, de gestão direta pelo próprio poder público, entendeu o governo federal que isso representaria intervenção do Estado no domínio econômico, que somente seria possível em casos específicos previstos em lei e reconhecidos os imperativos de segurança nacional ou relevante interesse público, observados setores e áreas de atuação previstos em lei complementar, em atendimento ao 
artigo 137, cumulado com o artigo 37, inciso XIX, da Constituição Federal, que adotou o princípio da subsidiaridade.

Em verdade, afora eventuais limitações jurídicas, o fato é que o Estado brasileiro é proprietário de enormes áreas cobertas por florestas, áreas estas que exigiriam um aparato grandioso para sua manutenção e proteção.

Intensos debates foram promovidos em relação à Lei Geral de Gestão das Florestas Públicas, sendo que o argumento dos opositores a sua aprovação a compreendiam como uma forma do Estado privatizar a floresta pública, possibilitando a sua exploração pelos particulares.

Em direção oposta, os defensores da aprovação de tal lei, defendiam a necessidade da instalação de uma efetiva política pública para a gestão de um patrimônio público e ambiental com enorme valor estratégico, tanto econômico, quanto social.

Maria Luiza Machado Granziera ${ }^{192}$, de forma acertada, aponta que a referida lei, por ser norma recente, para melhor compreensão de seu alcance, merece ser analisada pela verificação se "os instrumentos ali estabelecidos estão coerentes com os princípios estabelecidos e finalidades propostas", ao invés da discussão política simplesmente. Ainda, tal doutrinadora conclui que a Lei Geral de Gestão de Florestas Públicas:

(...) oferece uma proposta inovadora, na medida em que não estabelece apenas proibições mas formula uma real política pública que, no mínimo, fornece campo para a discussão, ao invés de bater na tecla não sem importância mas insuficiente da fiscalização, como único meio de impedir o dano ambiental e a degradação. (grifo nosso)

Concorda-se com a opinião de Maria Luiza Machado Granziera, pois muito se defende a necessidade do Estado apenas fiscalizar as áreas públicas recobertas por florestas, mantendo-as como um patrimônio intocável, mas pouco se discute sobre caminhos alternativos para a concretização de um modo de gestão de tal patrimônio público que atenda o princípio do desenvolvimento sustentável.

Se de um lado, a preservação do patrimônio ambiental é uma exigência constitucional, do outro, a sua exploração econômica baseada na sustentabilidade também o é, cabendo ao Estado e à sociedade construírem um modelo eficiente cujas bases são encontradas no novel diploma legal para gestão do patrimônio florestal público.

\footnotetext{
${ }^{192}$ Mecanismos de efetividade da lei sobre florestas públicas, in Revista de Direito Ambiental, ano 13, n. 49, jan.-mar./2008, p. 201-216.
} 


\subsection{Princípios da gestão das floretas públicas para produção sustentável:}

Em 1985, a Organização das Nações Unidas para Agricultura e Alimentação - FAO, o Programa das Nações Unidas para o Desenvolvimento - PNUD, o Banco Mundial e o "World Resources Institute"193 formularam o "Tropical Forestry Action Plan" (Plano de Ação das Florestas Tropicais), iniciativa na qual foram erigidas as bases para a discussão da implantação do manejo florestal sustentável em florestas tropicais no mundo todo.

$\mathrm{Na}$ Conferência das Nações Unidas sobre o Meio Ambiente e Desenvolvimento, realizada no Rio de Janeiro, no ano de 1992, foi elaborada a Agenda 21, a Declaração do Rio, a Declaração de Princípios sobre o Uso das Florestas, a Convenção sobre a Diversidade Biológica e a Convenção sobre Mudanças Climáticas.

Especificamente no capítulo 11, da Agenda 21, adotada pelos países signatários da Convenção Rio/92, foram inseridos os preceitos base para o combate ao desflorestamento, tais como:

a) manutenção dos múltiplos papéis e funções de todos os tipos de florestas;

b) aumento da proteção, manejo sustentável, conservação e reabilitação das florestas;

c) promoção de métodos eficazes de aproveitamento e avaliação para restauração plena dos bens e serviços proporcionados pelas florestas;

d) estabelecimento e fortalecimento do planejamento, avaliação e acompanhamento de programas, projetos e atividades da área florestal.

Eder Zanetti ${ }^{194}$ também aborda os princípios relativos ao manejo florestal sustentável das florestas, que foram estabelecidos na Conferência das Nações Unidas sobre o Meio Ambiente e Desenvolvimento (UNCED) e avalizados pelo Painel Intergovernamental de Florestas (IPF) e Fórum Intergovernamental de Florestas (IFF), apontando:

a) uso de mecanismos apropriados de participação para envolver todas as partes interessadas;

b) aplicação da descentralização, quando aplicável, e aumento do poder dos governos regionais e locais;

c) reconhecimento e respeito dos direitos tradicionais e costumes dos grupos indígenas, comunidades locais, moradores e proprietários das florestas;

\footnotetext{
${ }^{193}$ Esta é entidade não governamental internacional sediada em Washington, Estados Unidos da América.

${ }^{194}$ Meio Ambiente, Setor Florestal. Curitiba: Juruá, 2009. p. 21
} 
d) arranjos seguros e precisos para as áreas;

e) estabelecimento de mecanismos para coordenação efetiva e resolução de conflitos.

A "World Commission on Forests and Sustainable Development"195, publicou, em 1998, um documento intitulado “Our Forest, our Future” também em defesa da implantação do manejo florestal sustentável, como meio de conservação das florestas no mundo todo, principalmente para os países detentores de grande quantidade de delas.

Nesse documento encontra-se um conjunto de princípios aplicável a tal objetivo, expressos por valores como a indispensabilidade da participação da sociedade na discussão sobre o futuro das florestas e, principalmente, as comunidades que delas dependam para sobreviver, a definição de estratégias para a gestão das florestas, a criação de um sistema de certificação dos produtos florestais, que garanta o comércio somente daqueles provenientes de florestas exploradas de forma racional e sustentável etc.

Perante este quadro não é difícil concluir que há uma gama de princípios regentes da boa gestão das florestas, inclusive para aquelas que são públicas, princípios estes que formam o regramento básico do denominado manejo florestal sustentável.

E nisto que se espelhou o legislador quando, no artigo $2^{\circ}$, da Lei $n^{\circ}$ 11.284, de 02 de março de 2006, instituiu princípios voltados ao regramento da gestão de florestas públicas brasileiras.

Tais princípios da gestão de florestas públicas são os seguintes:

a) a proteção de ecossistemas, do solo, da água, da biodiversidade e valores culturais associados, bem como do patrimônio público;

b) o estabelecimento de atividades que promovam o uso eficiente e racional das florestas e que contribuam para o cumprimento das metas do desenvolvimento sustentável local, regional e de todo o País;

c) o respeito ao direito da população, em especial das comunidades locais, de acesso às florestas públicas e aos benefícios decorrentes de seu uso e conservação;

d) a promoção do processamento local e o incentivo ao incremento da agregação de valor aos produtos e serviços da floresta, bem como à diversificação industrial, ao desenvolvimento tecnológico, à utilização e à capacitação de empreendedores locais e da mão-de-obra regional;

e) o acesso livre de qualquer indivíduo às informações referentes à gestão de florestas públicas, nos termos da Lei n ${ }^{\circ} 10.650$, de 16 de abril de 2003;

\footnotetext{
${ }^{195}$ Também se trata de outra entidade não governamental sediada em Winnipeg, Manitoba, Canadá.
} 
f) a promoção e difusão da pesquisa florestal, faunística e edáfica ${ }^{196}$, relacionada à conservação, à recuperação e ao uso sustentável das florestas;

g) o fomento ao conhecimento e a promoção da conscientização da população sobre a importância da conservação, da recuperação e do manejo sustentável dos recursos florestais;

h) a garantia de condições estáveis e seguras que estimulem investimentos de longo prazo no manejo, na conservação e na recuperação das florestas.

Da primeira assertiva se extrai que a gestão da floresta pública deve ser conduzida mirando-se a proteção dos múltiplos aspectos do meio ambiente, tais como o ecossistema como um todo, elementos naturais e culturais, principalmente das comunidades que dependem da floresta para sua sobrevivência.

As atividades desenvolvidas na gestão de florestas públicas devem promover o uso eficiente e sustentável das mesmas, expresso por práticas como a agregação de valor aos produtos florestais, unindo-se novas tecnologias e capacitação ao povo da floresta.

Também, as pesquisas devem ser direcionadas à conservação, recuperação e uso sustentável aliado à educação e informação ambiental, tudo isto para se construir um ambiente institucional estável para atrair os investimentos privados de longo prazo.

Portanto, os referidos princípios de gestão das florestas públicas gravitam em torno de alguns elementos nucleares: educação, informação e pesquisa ambientais mais a proteção aos valores cultuais das pessoas que garantem sua sobrevivência das florestas.

Os citados princípios devem servir de vetores às legislações estadual, distrital e municipal de caráter supletivo e complementar, o que justifica a intitulação da Lei $\mathrm{n}^{\circ}$ 11.284, de 02 de março de 2006, como "Lei Geral de Gestão das Florestas Públicas", utilizando-se o termo "geral" como designativo do fato das normas nela constantes possuírem caráter básico em relação às aludidas normas que vierem a suplementá-la ou complementá-la.

\footnotetext{
${ }^{196}$ Define-se a fauna edáfica como a fauna que vive diretamente no solo.
} 


\section{CAPÍTULO 4 \\ GESTÃO DAS FLORESTAS PÚBLICAS}

\subsection{Considerações iniciais:}

A Lei Geral de Gestão das Florestas Públicas tem por objeto a disciplina das diversas formas de gestão sustentável das florestas públicas brasileiras, entre elas a concessão florestal que por tal lei foi a mais detalhada.

Assim sendo, a compreensão de todos os componentes da concessão florestal exige um encontro, em primeiro plano, com as demais formas de gestão das florestas públicas, pretensão do presente capítulo.

Para se alcançar cada uma das formas de gestão de florestas públicas previstas na citada lei, de proêmio é necessária uma melhor delimitação do que são as florestas públicas.

No artigo $3^{\circ}$, inciso I, da Lei Geral de Gestão de Florestas Públicas, as florestas públicas são conceituadas como "florestas naturais ou plantadas, localizadas nos diversos biomas brasileiros, em bens sob o domínio da União, dos Estados, dos Municípios, do Distrito Federal ou das entidades da administração indireta”.

O critério legal para determinação da natureza da floresta como pública é o fato dela recobrir uma área sob o domínio da União, Estados, Municípios, Distrito Federal ou entidades da administração pública indireta.

Em relação às áreas inseridas no acervo patrimonial das entidades da administração direta, mesmo não tendo havido a preocupação de se detalhar tal aspecto na lei, deve-se entender que apenas as florestas existentes em áreas sob o domínio de autarquias e fundações públicas é que podem ser qualificadas como públicas, eis que somente estas entidades da administração indireta possuem natureza jurídica de direito público.

A gestão das florestas públicas, conforme prevê o "caput", do artigo $4^{\circ}$, da Lei Geral de Gestão de Florestas Públicas é formada por três modos de atuação da Administração Pública, assim definidos:

a) criação e gestão direta de florestas nacional, estadual e municipal, nos termos do artigo 17, da Lei do Sistema Nacional das Unidades de Conservação; 
b) antes da implementação de concessões florestais, a destinação de florestas públicas às comunidades locais por meio da criação de reservas extrativistas e reservas de desenvolvimento sustentável, concessões de uso e outras formas previstas em lei;

c) a concessão florestal de florestas naturais ou plantadas e das unidades de manejo das florestas nacionais, estaduais e municipais supra referidas.

Portanto, em duas das três formas de gestão de florestas públicas, o uso é outorgado aos particulares, pois, pelo primeiro meio, o poder público mantém para si a gestão das citadas florestas.

Dessas duas modalidades, em que o uso é outorgado ao particular, uma delas é específica para as comunidades locais, enquanto a outra é direcionada a qualquer pessoa jurídica constituída sob as leis brasileiras, inclusive em consórcio e também associações de comunidades locais.

As hipóteses de outorga do uso de florestas públicas às comunidades locais são aquelas previstas no artigo $6^{\circ}$, da Lei Geral de Gestão de Florestas Públicas, melhor delimitadas adiante.

Feitos tais esclarecimentos iniciais, nos tópicos adiante cada um dos instrumentos de gestão das florestas públicas são visitados, com ênfase à concessão florestal, objetivo central deste trabalho, em capítulo apartado.

\subsection{Gestão direta da Floresta Nacional, Estadual e Municipal:}

A primeira modalidade de gestão das florestas públicas é a criação de floresta nacional, estadual e municipal, em atendimento ao artigo 17, da Lei do Sistema Nacional de Unidades de Conservação.

Este tema foi abordado no tópico 1.7.8.2, do capítulo 1, deste trabalho, valendo relembrar o seguinte em relação à floresta nacional, estadual e municipal:

a) é espécie de unidade de uso sustentável, portanto nela se explora o meio ambiente com respeito à biodiversidade, aos atributos ecológicos e de forma socialmente justa e economicamente viável;

b) é uma área recoberta por florestas de espécies predominantemente nativas, pois nela podem ser introduzidas espécies não autóctones, conforme o artigo $31, \S 1^{\circ}$, da citada Lei do Sistema Nacional de Unidades de Conservação, de acordo com o que dispuser seu regulamento e plano de manejo; 
c) tem como objetivo básico o uso múltiplo sustentável dos recursos naturais e a pesquisa científica, com ênfase em métodos para exploração sustentável de florestas nativas;

d) é sempre de posse e domínio públicos, devendo ser desapropriadas as áreas particulares existentes dentro de seus limites;

e) no seu interior é permitida a permanência de populações tradicionais que a habitem quando de sua criação, devendo ser regulamentada a posse e uso das áreas ocupadas por contrato e conforme o regulamento da unidade, em atendimento ao artigo 23, "caput", da Lei do Sistema Nacional de Unidades de Conservação;

f) não é proibida a visitação pública e pesquisa científica;

g) um conselho consultivo é responsável por sua administração, constituído por organizações da sociedade civil, populações residentes e órgão público, devendo a presidência ser exercida por este último.

O que qualifica uma população como tradicional é o fato de ser residente no interior da floresta nacional, estadual e municipal antes de sua criação pelo poder público e, principalmente, ter como base econômica de sobrevivência o extrativismo sustentável dos recursos florestais.

O extrativismo, no artigo $2^{\circ}$, inciso XII, da Lei do Sistema Nacional de Unidades de Conservação é conceituado como "sistema de exploração baseado na coleta e extração, de modo sustentável, de recursos naturais renováveis".

A gestão direta da floresta nacional, estadual e municipal é desempenhada conforme o seu plano de manejo e regulamento.

O plano de manejo, baseado nos objetivos gerais da floresta nacional, estadual e municipal, tem por finalidade três objetivos:

a) fixar o zoneamento de tal unidade de conservação;

b) baixar as normas referentes ao uso e manejo de seus recursos ambientais;

c) prever a implantação de estruturas físicas necessárias à gestão.

O plano de manejo, portanto, é documento técnico composto de normas com características de zoneamento, regramento e plano diretor da floresta nacional, estadual e municipal.

Conforme defende Ana Lucia das Graças Amador ${ }^{197}$, técnica do Instituto Brasileiro do Meio Ambiente e Recursos Naturais Renováveis - IBAMA, o plano de manejo deve ser elaborado de forma participativa, gradativa e contínua, pois: "Dessa

\footnotetext{
${ }^{197}$ Roteiro Metodológico para Elaboração de Plano de Manejo para Florestas Nacionais, Brasília: IBAMA,
} 2003. p. 15 
forma, os conhecimentos sobre os recursos naturais e culturais e a exploração sustentável dos mesmos evoluirão de forma progressiva e integrada, possibilitando ações de manejo de maior eficácia, eficiência e efetividade.".

A doutrinadora também esclarece que a forma de trabalho participativa, agregando "esforços de organismos governamentais, não-governamentais e representantes da sociedade civil" responsáveis pelas deliberações na elaboração do plano de manejo, além de "superar antigo paradigma de autoritarismo estatal", demonstra que "a responsabilidade pela conservação do patrimônio ambiental é de todos os atores sociais envolvidos".

A referida metodologia é constituída basicamente por reuniões técnicas, oficinas de planejamento e elaboração efetiva do plano de manejo da floresta nacional, estadual ou municipal.

Considera-se a orientação da doutrinadora correta, uma vez que a participação de entidades não governamentais, representantes das populações tradicionais residentes, entre outros, na elaboração do plano de manejo da floresta nacional, estadual e municipal, garante a sua eficácia e efetividade, na medida em que um regramento que decorra de consenso entre as partes possibilita que sejam minimizados conflitos futuros.

$\mathrm{Na}$ gestão direta da floresta nacional, estadual e municipal, o poder público também poderá firmar convênios, termos de parceria, contratos ou instrumentos similares com terceiros, observados os procedimentos licitatórios e demais exigências legais pertinentes, para as atividades subsidiárias, conforme artigo $5^{\circ}$, da Lei Geral de Gestão de Florestas Públicas.

Contudo, no $\S 1^{\circ}$, do mesmo dispositivo, foi prevista regra especial quanto à duração dos contratos e instrumentos similares referidos, devendo ficar limitados a 120 (cento e vinte) meses.

Entende-se que essa regra específica afasta a aplicação do artigo 57, incisos II e IV, da Lei no 8.666, de 21 de junho de 1993 (Lei Geral de Licitações e Contratos Administrativos) e alterações posteriores, que prevêem que o prazo nos contratos de prestação de serviços é limitado a 60 (sessenta) meses e nos contratos de aluguel de equipamentos e à utilização de programas de informática é de 48 (quarenta e oito) meses, sendo permitida, nos dois casos, a prorrogação por mais 12 (doze) meses, em caráter excepcional, devidamente justificado e mediante autorização da autoridade superior, conforme $\S^{\circ}$ do mesmo artigo. 
Percebe-se que a Lei Geral de Gestão de Florestas Públicas prevê o dobro do prazo de vigência dos contratos e demais instrumentos similares cujo objeto sejam atividades subsidiárias da gestão desenvolvida conforme o plano de manejo da floresta nacional, estadual ou municipal.

A lei não delineou precisamente quais seriam tais atividades subsidiárias, de tal forma que qualquer contratação ou outra espécie de ajuste de vontades estabelecido em benefício da floresta nacional, estadual e municipal, poderá reger-se pela regra especial que prevê o prazo máximo de 120 (cento e vinte) meses.

A intenção da norma, provavelmente, tenha sido a de adequar a contratação de atividades subsidiárias aos prazos aplicáveis à gestão da floresta nacional, estadual e municipal, geralmente constantes nos planos de manejo.

Deve-se lembrar, também, que a floresta nacional, estadual e municipal não possui personalidade jurídica própria, pois é apenas um espaço territorial especialmente protegido, fazendo parte, assim, do acervo patrimonial do ente público.

A licitação e posterior contratação, desta forma, é conduzida e concretizada perante a pessoa jurídica que detém o domínio e gestão da floresta nacional, estadual e municipal, por intermédio do órgão ambiental competente pela sua gestão.

No capítulo 1, tópico 1.7.8.3, foi anotado que compete à autarquia federal denominada Instituto Chico Mendes de Conservação da Biodiversidade a execução de todas as ações referentes às unidades de conservação federais, entre elas a floresta nacional.

Portanto, compete a tal entidade da administração pública indireta federal conduzir os procedimentos de licitação e contratação de "atividades subsidiárias" à gestão de florestas nacionais (FLONAS), utilizando-se da regra específica de prazo contratual, prevista no artigo $5^{\circ}, \S 1^{\circ}$, da Lei Geral de Gestão de Florestas Públicas.

Outra regra específica está prevista no $\S 2^{\circ}$, do mesmo dispositivo legal, que permite, nas aludidas licitações para contratações de "atividades subsidiárias" à gestão direta, a adoção do critério da melhor técnica, previsto no artigo 26, inciso II, da mesma Lei Geral de Gestão de Florestas Públicas.

Interessante notar que, o referido critério de melhor técnica é delimitado por uma série de subcritérios, cujos parâmetros e fórmulas de aferição devem ser previstos no edital da licitação, a saber:

a) menor impacto ambiental;

b) maiores benefícios sociais diretos; 
c) maior eficiência;

d) maior agregação de valor ao produto ou serviço florestal na região da concessão.

Mais uma vez, a Lei Geral de Gestão de Florestas Públicas inovou em relação aos critérios de julgamento da melhor proposta em licitações, assunto que será esmiuçado adiante.

\subsection{Gestão pela outorga da exploração da floresta pública a comunidades locais:}

A segunda forma de gestão de florestas públicas para a produção sustentável é a destinação às comunidades locais.

O "caput", do artigo $6^{\circ}$, da Lei Geral de Gestão de Florestas Públicas, prevê que, antes mesmo da realização das concessões florestais, as florestas públicas ocupadas ou utilizadas por tais comunidades locais devem ser identificadas e destinadas ao uso de tais comunidades.

As três formas de destinação são as previstas nos incisos do citado dispositivo legal:

a) criação de reservas extrativistas e reservas de desenvolvimento sustentável;

b) concessão de uso por meio de projetos de assentamento florestal, de desenvolvimento sustentável, agroextrativistas ou outros similares, nos termos do artigo 189, da Constituição Federal e das diretrizes do Programa Nacional de Reforma Agrária;

c) outras formas previstas em lei.

Tais formas merecem melhor detalhamento nos tópicos seguintes, assim como o que deve ser entendido como comunidades locais.

\subsubsection{Conceito de comunidades locais:}

$\mathrm{O}$ artigo $3^{\circ}$, inciso $\mathrm{X}$, da Lei Geral de Gestão de Florestas Públicas conceitua comunidades locais como "populações tradicionais e outros grupos humanos, organizados por gerações sucessivas, com estilo de vida relevante à conservação e utilização sustentável da diversidade biológica”.

Antes do estabelecimento desse conceito legal, no artigo 20, da Lei do Sistema Nacional de Unidades de Conservação, na definição da reserva de desenvolvimento sustentável foi inserido conceito para populações tradicionais como populações "cuja existência baseia-se em sistemas sustentáveis de exploração dos recursos 
naturais, desenvolvidos ao longo de gerações e adaptados às condições ecológicas locais e que desempenham um papel fundamental na proteção da natureza e na manutenção da diversidade biológica".

Na Lei Geral de Gestão de Florestas Públicas a expressão utilizada foi "comunidades locais", enquanto na Lei do Sistema Nacional de Unidades de Conservação, a expressão utilizada foi "populações tradicionais".

Na lei mais recente é visível que o conceito de "comunidade local" é um gênero, do qual é espécie a "população tradicional", pois a dicção do dispositivo legal inclui "e outros grupos humanos".

Pode-se considerar, porém, que as duas expressões designam praticamente um mesmo objeto, ou seja, pessoas que sobrevivem há gerações dos recursos ambientais proporcionados pela floresta, de forma sustentável, respeitando a diversidade biológica e, em conseqüência, protegendo o meio ambiente.

Em relação às comunidades locais previstas na Lei Geral de Gestão de Florestas Públicas, podem ser pinçados os seguintes elementos como caracterizadores:

a) espacial: tais pessoas vivem na floresta;

b) cultural: a cultura e costumes dessas pessoas são voltados à exploração dos recursos que a floresta lhes fornece, porém de forma sustentável, pois suas ações causam baixo impacto e contribuam para a conservação da biodiversidade;

c) temporal: são pessoas que há muitas gerações vivem na e da floresta, não tendo precisado a lei um número determinado de tais gerações.

A respeito desse assunto, Márcia Dieguez Leuzinger ${ }^{198}$ manifesta idéia semelhante:

Somente será considerada população tradicional, para os fins de proteção especial conferida pelos diferentes diplomas legais, aquelas cujas ações produzam baixo impacto e/ou contribuam para a proteção da biodiversidade. Isso se confirma com a definição de comunidades locais estabelecida pela Lei $\mathrm{n}^{\circ} 11.284 / 06$, que dispõe sobre a gestão de florestas públicas para utilização sustentável (...) . Este diploma legal trata as comunidades locais como gênero que engloba populações tradicionais. (grifo nosso)

198 Natureza e Cultura - Unidades de Conservação de Proteção Integral e Populações Tradicionais Residentes, Curitiba: Letra da Lei, 2009. p. 209 
A mesma doutrinadora ${ }^{199}$ conclui que, para os fins do uso da floresta pública, deve ser considerada uma comunidade local aquela população tradicional "cujo estilo de vida seja relevante à conservação e utilização sustentável da biodiversidade”.

Além desses dois diplomas legais, na Convenção sobre a Diversidade Biológica - CDB, internalizada no direito pátrio pelo Decreto $\mathrm{n}^{\circ} 2.519$, de 16 de março de 1998 e assinada pelo Brasil durante a ECO-92, foi adotada a expressão "comunidades locais e populações indígenas", no seu artigo $8^{\circ}$, associando-as a grupos humanos "com estilo de vida tradicionais relevantes à conservação e à utilização sustentável da diversidade biológica" (grifo nosso).

Na Medida Provisória n 2.186-16, de 23 de agosto de 2001, que dispõe sobre o acesso ao patrimônio genético, a proteção e conhecimento tradicional associado, a repartição de benefícios e à tecnologia e transferência de tecnologia para sua conservação e utilização, no seu artigo $7^{\circ}$, incisos II e III, são definidos o conhecimento tradicional associado como "informação ou prática individual ou coletiva de comunidade indígena ou de comunidade local, com valor real ou potencial, associada ao patrimônio genético" e a comunidade local como "grupo humano, incluindo remanescentes de comunidades de quilombos, distinto por suas condições culturais, que se organiza, tradicionalmente, por gerações sucessivas e costumes próprios, e que conserva suas instituições sociais e econômicas" (grifo nosso).

Na Lei nº 11.428, de 22 de dezembro de 2006 (Lei de Proteção do Bioma Mata Atlântica), no seu artigo $3^{\circ}$, é assim definida população tradicional: "população vivendo em estreita relação com o ambiente natural, dependendo de seus recursos naturais para a sua reprodução sociocultural, por meio de atividades de baixo impacto ambiental".

No Decreto $n^{\circ}$ 6.040, de 07 de fevereiro de 2007, que instituiu a Política Nacional de Desenvolvimento Sustentável dos Povos e Comunidades Tradicionais, no seu artigo $3^{\circ}$, inciso I, são conceituados povos e comunidades tradicionais como "grupos culturalmente diferenciados e que se reconhecem como tais, que possuem formas próprias de organização social, que ocupam e usam territórios e recursos naturais como condição para sua reprodução cultural, social, religiosa, ancestral e econômica, utilizando conhecimentos, inovações e práticas gerados e transmitidos pela tradição".

Portanto, extrai-se das definiçõos legais, com diferentes graus de detalhamento, que são quase sinônimas as expressões comunidades locais, populações

\footnotetext{
${ }^{199}$ Loc. cit.
} 
tradicionais e comunidades tradicionais, sendo características marcantes aqueles elementos já apontados, quanto ao território (espacial) que ocupam, a cultura e costumes que cultivam há tempos imemoriais (cultural e temporal).

Cristiane Derani ${ }^{200}$ desfila uma série de caracteres que identificariam uma comunidade como tradicional: "1. propriedade comunal; 2. produção voltada para dentro (valor de uso); 3. distribuição comunitária do trabalho não assalariado; 4. tecnologia desenvolvida e transmitida por processo comunitário; 5. transmissão de propriedade, conhecimento, pela tradição comunitária intergeracional".

Dentre os elementos coligidos pela doutrinadora, merece destaque a menção indireta ao fato de tais comunidades viverem em um território, o traço espacial já referido, que não seria necessariamente de propriedade dos seus habitantes.

Além disso, as práticas conservacionistas de tais populações podem ser vislumbradas nas demais características coligidas pela doutrinadora, sendo este o segundo elemento, costumeiro ou cultural.

Todavia, considera-se que os elementos caracterizadores das populações tradicionais elaborados por Márcia Dieguez Leuzinger ${ }^{201}$ são mais completos, a saber:

1 - auto-identificação e identificação pela sociedade envolvente como pertencentes a um grupo distinto;

2 - práticas sustentáveis de exploração dos recursos naturais, que produzam baixo impacto e contribuíam para a proteção da diversidade biológica;

3 - dependência, para sua sobrevivência física e cultural, da natureza, seus ciclos e seus elementos;

4 - importância das atividades de subsistência e reduzida acumulação do capital;

5 - territorialidade, entendida como noção de pertencimento a determinado território, em cujos limites se reproduzem crenças, mitos e práticas, ancestrais ou não, que reatualizam e reivificam a memória coletiva;

6 - posse comunal e gestão compartilhada dos recursos naturais;

7 - transmissão de conhecimento por meio da tradição comunitária intergeracional, normalmente tradição oral.

Desta forma, os destinatários da norma podem ser denominados de comunidades locais ou populações tradicionais, atendidos os elementos caracterizadores constantes na legislação.

\footnotetext{
${ }^{200}$ Patrimônio genético e conhecimento tradicional associado: considerações jurídicas sobre seu acesso. In: LIMA, André. O Direito para o Brasil Socioambiental, Porto Alegre: Fabris Editores, 2002. p. 153

${ }^{201}$ Op. cit., p. 223
} 


\subsubsection{Criação de reservas extrativistas e reservas de desenvolvimento sustentável:}

O primeiro modo de destinação às comunidades locais das florestas públicas tradicionalmente por elas exploradas, previsto no artigo $6^{\circ}$, inciso I, da Lei de Gestão de Florestas Públicas, consiste na criação de reservas extrativistas e reservas de desenvolvimento sustentável, espécies de unidades de uso sustentável também disciplinada pela Lei do Sistema Nacional de Unidades de Conservação.

As principais características das reservas extrativistas e reservas de desenvolvimento sustentável foram expostas no capítulo 1, tópico 1.7.8.2 deste trabalho, podendo-se relembrar que o ponto comum entre elas é que são voltadas ao uso das populações tradicionais, cuja subsistência baseia-se em sistemas de sustentáveis de exploração dos recursos naturais.

A formalização do uso das unidades de manejo das reservas extrativistas e reservas de desenvolvimento sustentável às comunidades locais beneficiárias está disposta no artigo 23, da Lei do Sistema Nacional de Unidades de Conservação, da seguinte forma: "Artigo 23 - A posse e o uso das áreas ocupadas pelas populações tradicionais nas Reservas Extrativistas e Reservas de Desenvolvimento Sustentável serão regulados por $\underline{\text { contrato, }}$ conforme se dispuser no regulamento desta Lei” (grifo nosso).

$\mathrm{O}$ artigo 13, do Decreto $\mathrm{n}^{\mathrm{o}}$ 4.340, de 22 de agosto de 2002 (Regulamento da Lei do Sistema Nacional de Unidades de Conservação), detalhando o referido dispositivo assim prevê:

Artigo 13. O contrato de concessão de direito real de uso e o termo de compromisso firmados com populações tradicionais das Reservas Extrativistas e Reservas de Uso Sustentável devem estar de acordo com o Plano de Manejo, devendo ser revistos, se necessário. (grifo nosso)

Dos dispositivos legais transcritos, conclui-se que são dois os instrumentos de formalização do uso de unidades de manejo, pelas populações tradicionais, nas reservas extrativistas e reservas de desenvolvimento sustentável: $\underline{\text { o contrato de }}$ concessão de direito real de uso e termo de compromisso.

A primeira figura, de índole contratual, na verdade, trata-se de concessão de direito real de uso disciplinada pelo Decreto-lei $\mathrm{n}^{\circ} 271$, de 28 de fevereiro de 1967, com alterações da Lei $\mathrm{n}^{\circ}$ 11.481, de 31 de maio de 2007. 
No artigo $7^{\circ}$, do citado diploma legal modificado, consta que tal concessão de direito real de uso é instituída como direito real resolúvel, para fins específicos de regularização fundiária de interesse social, urbanização, industrialização, edificação, cultivo da terra, aproveitamento sustentável das várzeas, preservação das comunidades tradicionais e seus meios de subsistência ou outras modalidades de interesse social em áreas urbanas, tanto sobre terrenos públicos, quanto particulares, podendo ser remunerada ou gratuita, por tempo certo ou indeterminado.

Essa concessão pode ser contratada por instrumento público ou particular, ou mediante simples termo administrativo, devendo ser escrita e cancelada em livro especial e poderá ser resolvida caso o concessionário destine o imóvel, seu objeto, a uma finalidade diversa da estabelecida no contrato (ou termo) ou descumpra cláusula resolutória do ajuste.

A lei também admite que essa concessão de direito real de uso seja transferida por ato "inter vivos" ou por sucessão legítima ou testamentária, desde que permitido no contrato, como os demais direitos reais sobre coisas alheias, registrando-se a respectiva transferência.

Thiago Marrara ${ }^{202}$ relembra que a concessão de direito real de uso é uma espécie do gênero concessão de uso, o que também é relembrado Floriano Peixoto de Azevedo Marques Neto ${ }^{203}$, para quem a primeira “(...) se particulariza por ter previsão legal, possuir um caráter de direito real reforçado e ser prestante apenas para conferir ao particular o direito de dar ao bem público uma das finalidades especificamente previstas no texto legal.".

Maria Sylvia Zanella Di Pietro ${ }^{204}$ salienta que tal concessão tem por objeto bens públicos imóveis dominicais, podendo também, a letra da lei, ser utilizado em terrenos particulares, entendimento este também expresso por Floriano Peixoto de Azevedo Marques Neto ${ }^{205}$.

Por outro lado, caso o bem público objeto da concessão não seja dominical, entende Marcos Juruena Villela Souto ${ }^{206}$ que dever haver a prévia desafetação,

\footnotetext{
${ }^{202}$ Bens Públicos Domínio Urbano Infra-estrutura. Belo Horizonte: Fórum, 2007. p. 145

${ }^{203}$ O Regime Jurídico das Utilidades Públicas: função social e exploração econômica dos bens públicos, São Paulo, 2008, Tese de livre docência, Data de defesa 02.10.2008, Faculdade de Direito da Universidade de São Paulo, p. 421

${ }^{204}$ Direito Administrativo, São Paulo: Atlas, 2008. p. 664

205 Op. cit., p. 422

${ }^{206}$ Direito Administrativo das Concessões, Rio de Janeiro: Lumen Juris, 2004. p. 321
} 
pois tal concessão é "regida pelo direito público, como os demais contratos administrativos", com o que se concorda.

No caso das reservas extrativistas e reservas de desenvolvimento sustentável, em cujas áreas encontram-se as unidades de manejo objeto da concessão de direito real de uso ora comentada, tratam-se de bens dominicais sob gestão da Administração Pública visando interesse geral de preservação ambiental.

Neste ponto, importante a explicação de Maria Sylvia Zanella Di Pietro ${ }^{207}$, quanto ao fato de ser entendimento hodierno que, quanto aos bens públicos dominicais, "a natureza desses bens não é exclusivamente patrimonial; a sua administração pode visar, paralelamente, a objetivos de interesse geral." (grifo nosso).

A mesma doutrinadora ${ }^{208}$, inclusive, exemplifica que o uso dos bens dominicais pode ser outorgado ao particular visando fins como urbanização, industrialização, cultivo, culturais, recreativos, esportivos, “(...) mesmo quando esses bens não são utilizados por terceiros ou diretamente pela Administração Pública, podem ser administrados no benefício de todos, como as terras públicas onde se situem florestas, mananciais ou recursos naturais de preservação permanente." (grifo nosso).

A finalidade da concessão de direito real de uso para as populações tradicionais, conforme se depreende dos fins que justificam a criação de reservas extrativistas e reservas de desenvolvimento sustentável, é preservar o modo de sobrevivência sustentável dessas comunidades, o que faz concluir que, caso o mesmo seja descaracterizado, poderá ocorrer a resolução do contrato, por desatendimento à sua finalidade.

No mesmo caminho de compreensão trilha Marcos Juruena Villela Souto $^{209}$, quanto à necessidade de atendimento da finalidade no contrato de concessão de direito real de uso: “(...) é, pois, o atendimento de um interesse social dentro do prazo estipulado, resolvendo-se o contrato se essa finalidade não for atendida" (grifo nosso).

Quanto ao uso das reservas extrativistas e reservas de desenvolvimento sustentável pelas comunidades locais, trata-se de uso privativo, pois, conforme bem define Maria Sylvia Zanella Di Pietro ${ }^{210}$ : este uso “(...) é o que a Administração Pública confere, mediante título jurídico individual, a pessoa ou grupo de pessoas determinadas, para que o exerçam, com exclusividade, sobre parcela de bem público." (grifo nosso).

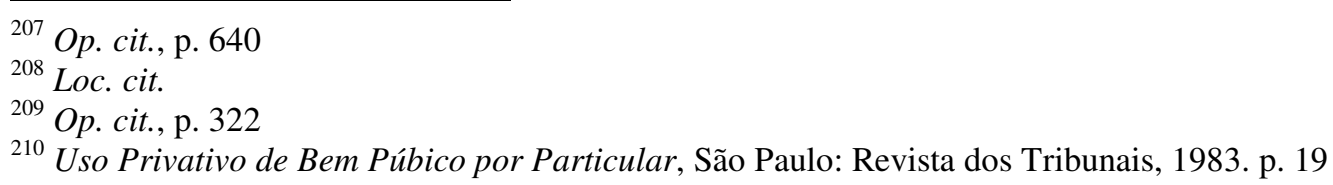


A lei regente da matéria prevê que a concessão de direito real de uso poderá ter caráter oneroso, sendo que, no presente caso, de outorga de uso de áreas das citadas unidades de conservação às populações tradicionais, por haver um interesse social intrínseco, justifica-se a concessão a título gratuito.

Quanto à promoção de licitação prévia ao estabelecimento do contrato de concessão de direito real de uso, prevê o artigo $23, \S 3^{\circ}$, da Lei $n^{\circ} 8.666$, de 21 de junho de 1993, com redação alterada pela Lei n 8.883, de 08 de junho de 1994 (Lei Geral de Licitações e Contratos Administrativos) que a concorrência é a modalidade de licitação cabível, qualquer que seja o valor de seu objeto, também nas concessões de direito real de uso.

Na mesma lei, no artigo 17, inciso I, constam as regras básicas para alienação de bens imóveis da Administração Pública, que deve ser precedida da manifestação de interesse público devidamente justificado, avaliação, autorização legislativa e licitação na modalidade de concorrência.

Tais dispositivos compõem a regra geral de licitação prévia à concessão de direito real de uso, juntamente com a regra do artigo $2^{\circ}$, da Lei Geral de Licitações e Contratos Administrativos, salvo as exceções nela própria existentes.

No presente caso, de concessão de direito real de uso de unidades de manejo de reservas extrativistas e reservas de desenvolvimento sustentável às comunidades locais, prescreve o artigo $6^{\circ}, \S 3^{\circ}$, da Lei Geral de Gestão de Florestas Públicas, que é dispensada a licitação.

Portanto, há uma regra específica de dispensa de licitação para regularização de posses de comunidades locais sobre áreas por elas tradicionalmente ocupadas ou utilizadas, que sejam imprescindíveis à conservação dos recursos essenciais para sua reprodução física e cultural, regra esta aplicável à situação ora debatida.

Mesmo que tal regra não existisse, entende-se que seria dispensável de licitação, uma vez que faltaria um requisito básico para sua exigência: a competitividade decorrente da existência de vários interessados no objeto da futura contratação, que possibilita, em tese, a escolha de uma proposta mais vantajosa à Administração Pública.

Ora, inexiste a referida competitividade na medida em que as comunidades locais são específicas de cada área de manejo das reservas extrativistas e reservas de desenvolvimento sustentável.

Por outro lado, quanto à dispensa de autorização legislativa prévia, não se encontra disciplina de forma direta na Lei Geral de Gestão de Florestas Públicas para a 
concessão de direito real de uso de unidades de manejo de reservas extrativistas e reservas de desenvolvimento sustentável, como ocorre com algumas hipóteses específicas do artigo 17, da Lei Geral de Licitação e Contratos Administrativos.

Em tal dispositivo legal, que disciplina situação específica de regularização fundiária na Amazônia Legal, é exigida uma dimensão máxima de área, de até mil e quinhentos hectares, para tal finalidade.

Desta forma, pode-se discutir a possibilidade de aplicação de tal limite às áreas de unidade de manejo de reservas extrativistas e reservas de desenvolvimento sustentável, com a finalidade de dispensar autorização legislativa específica.

Como o limite previsto na Lei Geral de Licitações e Contratos Administrativos tem por escopo a proteção do caráter social da regularização fundiária de áreas da Amazônia Legal, não se vê óbices à adoção de tal limite também na concessão de direito real de uso de unidades de manejo de reservas extrativistas e reservas de desenvolvimento sustentável às comunidades locais.

Entretanto, caso seja adotado o limite, deverá ser contemplada a regra especifica do artigo 15, $\S 1^{\circ}$, do Decreto $n^{\circ}$ 6.063, de 20 de março de 2007 (Regulamento da Lei Geral de Gestão de Florestas Públicas), que determina que as dimensões das florestas públicas a serem destinadas a comunidades locais, "individual ou coletivamente, deve considerar o uso sustentável dos recursos florestais, bem como o beneficiamento dos produtos extraídos, como a principal fonte de sustentabilidade dos beneficiários" e será, conforme $\$ 2^{\circ}$, do mesmo artigo, decorrente de "estudos e avaliações técnicas" elaboradas pelo Serviço Florestal Brasileiro - SFB.

Em outras palavras, a dimensão das áreas de manejo de tais unidades de conservação, cujo uso se outorga às comunidades locais, decorrerá de estudos técnicos que demonstrem ser tal área necessária ao uso sustentável e beneficiamento dos produtos

No artigo $6^{\circ}, \S 1^{\circ}$, da Lei Geral de Gestão de Florestas Públicas, há disposição no sentido que a destinação das florestas públicas às comunidades locais, antes da realização das concessões florestais, "será feita de forma não onerosa para o beneficiário e efetuada em ato administrativo próprio, conforme previsto em legislação específica" (grifo nosso).

A não onerosidade, portanto, é uma regra para todas as formas de trespasse do uso das florestas públicas às comunidades locais, desde que tais florestas não sejam aquelas destinadas à concessão florestal. 
Assim, a concessão de direito real de uso das unidades de manejo de reservas extrativistas e reservas de desenvolvimento sustentável, por força mesmo deste dispositivo, não deve ser onerosa às comunidades locais.

A expressão "ato administrativo próprio", contudo, não se amolda perfeitamente à hipótese da concessão de direito real de uso das citadas unidades, uma vez que sua natureza é contratual, conforme referido, por força do artigo 23, da Lei do Sistema Nacional de Unidades de Conservação, e artigo 13, do Regulamento de tal Lei, normas específicas que, neste ponto específico, afastam a aplicação da regra geral do artigo $7^{\circ}, \S^{\circ}$, do Decreto-Lei no 271, de 28 de fevereiro de 1967, na qual é admitida a instituição da aludida concessão por ato administrativo, designado como "simples termo administrativo" na dicção de tal dispositivo legal.

Ainda na outorga do uso de florestas públicas nas unidades de manejo de reservas extrativistas e reservas de desenvolvimento sustentável, tem-se a segunda forma, denominada "termo de compromisso" pelo artigo 13, do citado Regulamento da Lei do Sistema Nacional de Unidades de Conservação, retro transcrito, não tendo sido previsto no artigo 23, dessa Lei.

O termo de compromisso para disciplinar o uso, pelas comunidades locais, de unidades de manejo de reservas extrativistas e reservas de desenvolvimento sustentável, contudo, não é detalhado no referido diploma legal.

O termo de compromisso que tal Regulamento da Lei do Sistema Nacional de Unidades de Conservação disciplina é o do seu artigo 39, referente somente à situação das comunidades locais que se encontram temporariamente em áreas de unidades de proteção integral, até que sejam reassentadas, assunto que será melhor abordado adiante.

Neste sentido, o termo de compromisso é um ato administrativo que objetiva disciplinar uma situação temporária, transitória, que, no caso do artigo 39, do citado diploma legal, ocorre em áreas de unidades de proteção integral.

Perquirindo-se a razão da regra jurídica, pode-se entender que o termo de compromisso é instrumento transitório, para dispor sobre o uso de áreas de manejo de reservas extrativistas e reservas de desenvolvimento sustentável em favor das comunidades locais, enquanto tramita o processo de criação de tais unidades de conservação de uso sustentável. 


\title{
4.3.3 Concessões de uso para projetos de assentamento florestal e de outras naturezas:
}

O inciso II, do artigo $6^{\circ}$, da Lei Geral de Gestão de Florestas Públicas, ao disciplinar tal hipótese é bastante genérico, referindo-se a:

a) projetos de assentamento florestal;

b) projetos de desenvolvimento sustentável;

c) projetos agroextrativistas ou outros similares, todos conforme o artigo 189, da Constituição Federal e diretrizes do Programa Nacional de Reforma Agrária.

Nesta segunda modalidade de outorga do uso sustentável das florestas públicas às comunidades locais, denota-se o forte caráter agrário da Lei Geral de Gestão de Florestas Públicas, o que não passou despercebido por Benedito Ferreira Marques ${ }^{211}$ :

\begin{abstract}
Uma análise feita com essa preocupação conduzirá o interprete a concluir, de logo, que a Lei 11.284/06 contempla regras de vários ramos do Direito, notadamente do Direito Administrativo e do Direito Ambiental, mas também embute princípios e regras do Direito Agrário, a partir do objeto precípuo da nova ordem jurídica estabelecida com a promulgação dessa lei, que é a busca da produção, visando ao desenvolvimento sustentável, mediante atividades agrárias consubstanciadas na exploração de produtos e serviços florestais.
\end{abstract}

No mesmo dispositivo da Lei de Gestão de Florestas Públicas é prevista a necessidade de submissão de todos os projetos ao disposto no artigo 189, da Constituição Federal.

Tal dispositivo constitucional, por seu turno, prevê que os beneficiários da distribuição de imóveis rurais pela reforma agrária receberão títulos de domínio ou de concessão de uso, inegociáveis pelo prazo de dez anos, devendo ser conferidos ao homem ou à mulher, ou a ambos, independentemente do estado civil, nos termos e condições previstos em lei.

A legislação aplicável à matéria é basicamente a Lei $\mathrm{n}^{\circ} 4.504$, de 30 de novembro de 1964 (Estatuto da Terra) e Lei ${ }^{\circ}$ 8.629, de 25 de fevereiro de 1993, que minudenciam a concessão de uso de caráter contratual para fins de reforma agrária.

Tal concessão de uso para fins de reforma agrária, por sua vez, se expressa em projetos de assentamento florestal, de desenvolvimento sustentável,

\footnotetext{
211 Nuanças de agrariedade nas concessões de florestas públicas, in Revista de Informação Legislativa,
} Brasília, ano 45, n 177, jan.-mar./2008, p. 159-170 
agroextrativistas e outros similares, e é muito assemelhada àquela regrada pelo artigo $7^{\circ}$, do Decreto-Lei no 271, de 28 de fevereiro de 1967, analisada no tópico precedente.

Apesar da natureza contratual de tal concessão de uso para fins de reforma agrária, a licitação é dispensada, conforme prevê a alínea i), do inciso I e inciso II, do $\S 2^{\circ}$, ambos do artigo 17, da Lei Geral de Licitações e Contratos Administrativos, incluídos pela Lei $\mathrm{n}^{\mathrm{o}} 11.952$, de 25 de junho de 2009.

A hipótese tratada em tal dispositivo legal refere-se à alienação e concessão de direito real de uso, gratuita ou onerosa, de terras públicas rurais da União na Amazônia Legal onde incidam ocupações até o limite de 15 (quinze) módulos fiscais ou 1.500 ha (mil e quinhentos hectares), para fins de regularização fundiária, atendidos os requisitos legais mínimos de cultura, ocupação mansa e pacífica e exploração direta.

\subsubsection{Outras formas de outorga às comunidades locais:}

$\mathrm{O}$ artigo 39, do Decreto $\mathrm{n}^{\circ}$ 4.340, de 22 de agosto de 2002 (Regulamento da Lei do Sistema Nacional de Unidades de Conservação) prevê uma forma de outorga do uso privativo de florestas públicas a comunidades locais, referida no tópico 4.3.2 retro, por meio de termo de compromisso.

Trata-se de uma situação transitória, para disciplinar o uso de comunidades locais que ainda não foram reassentadas, após a criação de uma unidade de conservação de proteção integral.

No primeiro capitulo deste trabalho, precisamente no tópico 1.7.8.2, foram analisadas as diversas espécies de unidades de proteção integral, tais como a estação ecológica, reserva biológica, parque nacional, monumento natural e refúgio da vida silvestre, unidades estas em que os ecossistemas devem ser mantidos livres de alterações causadas por interferência humana, sendo nelas admitido apenas o uso indireto dos seus atributos naturais.

Tal uso indireto, conforme conceitua a própria Lei do Sistema Nacional de Unidades de Conservação (artigo $2^{\circ}$, inciso IX), é aquele que não envolve consumo, coleta, dano ou destruição dos recursos naturais.

Pois bem, por serem unidades de conservação em que não se permite a permanência de comunidades locais ou populações tradicionais, o artigo 42, da Lei do Sistema Nacional de Unidades de Conservação, lhes confere direito a indenização ou 
compensação pelas benfeitorias existentes e realocação, pelo Poder Público, em outras áreas, conforme condições acordadas.

O Regulamento da Lei do Sistema Nacional de Unidades de Conservação, nos artigos 35 a 39, disciplina o aludido procedimento de reassentamento.

O uso de florestas públicas a comunidades locais também pode ser outorgado pela forma prevista no $\S 2^{\circ}$, do artigo 17, da Lei do Sistema Nacional de Unidades de Conservação, que permite a permanência de tais comunidades em áreas de floresta nacional, estadual e municipal, desde que habitantes nelas antes da sua criação, assim como nas áreas de entorno.

$\mathrm{O}$ artigo $2^{\circ}$, inciso III, do Regulamento da Lei do Sistema Nacional de Unidades de Conservação, qualifica tais populações tradicionais como "residentes" e o instrumento de outorga do referido uso é denominado de "termo de uso", pelo artigo 18, do Regulamento da Lei Geral de Gestão de Florestas Públicas.

Segundo o citado dispositivo legal, o termo de uso deve indicar o prazo de vigência, os produtos florestais de uso tradicional e de subsistência, com as restrições e responsabilidades pelo manejo de espécies derivadas de tais produtos, bem como eventuais prejuízos ao meio ambiente e ao poder público.

Tal instrumento de outorga da floresta pública às populações tradicionais residentes deve identificá-las claramente por meio de estudos técnicos que também prevejam os produtos florestais usados e disciplinem a permanência dos comunitários em zonas de amortecimento.

O referido termo de uso é ato administrativo, não possuindo natureza jurídica contratual, podendo-se concluir, assim, que consiste numa permissão de uso bastante singular, aplicável somente a áreas de uma Floresta Nacional, Estadual ou Municipal em favor de indivíduos de comunidades locais.

Finalmente, é possível também o estabelecimento de uma autorização de uso em favor das comunidades locais para exploração de bens e serviços florestais, na forma regulada pelo artigo 25, do Regulamento da Lei do Sistema Nacional de Unidades de Conservação, para exploração de produtos, subprodutos ou serviços inerentes às unidades de conservação, desde que em acordo com os objetivos de cada uma das categorias de tais unidades. 


\subsubsection{Concessão florestal para comunidades locais:}

$\mathrm{O}$ artigo $6^{\circ}, \S 2^{\circ}$, da Lei Geral de Gestão de Florestas Públicas, prevê a possibilidade das comunidades locais participarem de licitação de concessões florestais, desde que se estruturem como associações comunitárias, cooperativas ou outras pessoas jurídicas admitidas na lei.

Tal forma de uso das florestas públicas possibilita, por exemplo, que comunidades de uma determinada localidade se constituam como pessoas jurídicas para concorrer visando explorar áreas de cobertura florestal diversas daquelas tradicionalmente ocupadas.

O objeto de concessões florestais para comunidades locais instituidoras de pessoas jurídicas que a representem, todavia, não são as áreas por elas tradicionalmente ocupadas, por disposição expressa do artigo 11, inciso IV, da Lei Geral de Gestão de Florestas Públicas.

Segundo tal dispositivo, as áreas tradicionalmente ocupadas pelas comunidades locais, juntamente com as terras indígenas e as que sejam de interesse para criação de unidades de conservação de proteção integral, não podem ser incluídas no Plano Anual de Outorga Florestal - PAOF, documento elaborado pelo poder concedente anualmente e descritivo de todas as florestas públicas a serem submetidas a processos de concessão florestal (artigo 10, da Lei Geral de Gestão de Florestas Públicas).

Em que pese o fato o estudo apurado de tal assunto no tópico próprio do capítulo seguinte, adianta-se que, em relação às unidades de conservação de proteção integral (existentes no momento da edição do PAOF), reservas extrativistas, reservas de desenvolvimento sustentável, reservas da fauna e reservas de relevante interesse ecológico, o artigo 11, inciso III, da Lei Geral de Gestão de Florestas Públicas admite que algumas de suas áreas sejam submetidas à concessão florestal, desde que previsto no plano de manejo da unidade de conservação.

Estes dois dispositivos revelam que as áreas ocupadas pelas comunidades locais não podem ser incluídas no PAOF para fins de concessão florestal, em regra, pois se admite que áreas desta espécie, existentes em reserva extrativista ou reserva de desenvolvimento sustentável, sejam objeto de concessão florestal desde que se assim estiver previsto nos respectivos planos de manejo de tais unidades de conservação.

Portanto, unidades de manejo de reserva extrativista ou de reserva de desenvolvimento sustentável, cuja exploração foi outorgada a uma comunidade local por 
meio de concessão de direito real de uso, poderão ser incluídas no PAOF e submetidas a concessão florestal, hipótese em que deverá haver um regramento próprio, dada a superposição de regimes jurídicos e obrigações entre a comunidade local, o poder concedente e o concessionário.

Nesta hipótese, ainda, pode-se até mesmo vislumbrar que a própria comunidade local seja concessionária de direito real de uso de algumas áreas da unidade de manejo e concessionária florestal de outras, de uma mesma reserva extrativista ou reserva de desenvolvimento sustentável.

Nas diferentes áreas, disciplinadas por diferentes instrumentos, a comunidade local explorará a floresta pública com enfoques diversos, pois, por exemplo, nas áreas objeto da concessão florestal não se admite que a exploração seja gratuita, sem remuneração ao poder concedente, conforme o que o artigo $3^{\circ}$, inciso VII, da Lei Geral de Gestão de Florestas Públicas.

Em razão também de tal dispositivo que conceitua a concessão florestal é que se exige a constituição de pessoa jurídica pelas comunidades locais que pretendam ser concessionárias.

Feita a exposição sucinta a respeito da concessão florestal às comunidades locais, as formas de outorga de uso de florestas públicas a comunidades locais podem assim ser resumidas:

a) desde que residentes em áreas antes da criação de unidades de proteção integral ou reservas extrativistas e reservas de desenvolvimento sustentável, por meio de termo de compromisso, com natureza de ato administrativo;

b) em áreas de entorno ou de manejo de reservas extrativistas e reservas de desenvolvimento sustentável, por meio de concessão de direito real de uso, de natureza contratual e não antecedida de licitação;

c) em projetos de assentamento florestal, de desenvolvimento sustentável, agroextrativistas e similares, por meio de concessão de uso para reforma agrária, de natureza contratual e não antecedida de licitação;

d) em áreas de residência nas florestas nacionais, estaduais e municipais, ou seu entorno, por meio de termo de uso, com natureza de ato administrativo;

e) para exploração de produtos, subprodutos ou serviços florestais inerentes às unidades de conservação, por meio de autorização de uso, com natureza de ato administrativo;

f) para áreas de unidades de manejo de reservas extrativistas e reservas de desenvolvimento sustentável cujos planos de manejo permitam e para outras áreas incluídas no PAOF, 
concessão florestal, de caráter contratual e antecedida de licitação, desde que tais comunidades locais constituam pessoa jurídica para tal fim.

\subsection{Concessão florestal:}

A terceira forma de gestão das florestas públicas, prevista no artigo $4^{\circ}$, inciso III, da Lei Geral de Gestão de Florestas Públicas é a concessão de uso de florestas naturais, florestas plantadas e unidades de manejo de floresta nacional, estadual e municipal, denominada concessão florestal.

Mantendo-se na superfície do tema, uma vez que no capítulo seguinte é que se pretende exauri-lo, pinça-se apenas que a concessão florestal é uma espécie de concessão de uso de bem público, de caráter contratual e obrigatoriamente antecedida de licitação na modalidade de concorrência.

A normatização incidente sobre essa espécie de concessão de uso é composta pelos fundamentos doutrinários, de caráter geral, expostos no capítulo 2 deste trabalho e pelas regras jurídicas peculiares da Lei Geral de Gestão de Florestas Públicas sobre as quais se faz o embate no próximo capítulo. 


\section{CAPÍTULO 5 \\ CONCESSÃO FLORESTAL}

5.1 Delimitação do conceito e natureza jurídica da concessão florestal:

Não oferece maior dificuldade a estruturação de um conceito para a concessão florestal, uma vez que o legislador da Lei Geral de Gestão de Florestas Públicas optou por disponibilizar no seu artigo $3^{\circ}$ uma série de definições, inclusive para a concessão florestal, no seu inciso VII.

A concessão florestal assim foi definida pelo legislador: "delegação onerosa, feita pelo poder concedente, do direito de praticar manejo florestal sustentável para exploração de produtos e serviços numa unidade de manejo, mediante licitação, à pessoa jurídica, em consórcio ou não, que atenda às exigências do respectivo edital de licitação e demonstre capacidade para seu desempenho, por sua conta e risco e por prazo determinado".

O conceito contido na lei pode ser qualificado de descritivo, pois expõe os elementos básicos da relação jurídica, tais como o caráter não gratuito, as partes e suas obrigações básicas, o objeto, o prazo determinado e a característica de submissão a regramento próprio.

As expressões técnicas do conceito, tais como "manejo florestal sustentável”, "unidade de manejo", "produtos florestais”, "serviços", também foram objeto de preocupação do legislador, que delineou os seus significados nos incisos do mesmo dispositivo legal.

O primeiro elemento do conceito legal de concessão florestal refere-se à sua onerosidade obrigatória, não sendo admitida a uma concessão florestal a título gratuito.

No artigo $13, \S 1^{\circ}$, da Lei Geral de Gestão de Florestas Públicas ${ }^{212}$, encontra-se regra que confirma o título obrigatoriamente oneroso da concessão florestal, apesar da redação ambígua de tal dispositivo legal induzir à idéia de que a citada onerosidade refere-se à licitação prévia e não à concessão florestal.

A onerosidade gera conseqüências importantes, tal como o fato das comunidades locais terem que remunerar o uso da floresta pública contemplada na concessão florestal, assunto este estudado no capítulo anterior.

\footnotetext{
${ }^{212}$ Dispõe o citado artigo $13, \S 1^{\text {o: }}$ "As licitações para concessão florestal serão realizadas na modalidade de concorrência e outorgadas a título oneroso."
} 
Conforme demonstrado, o caráter das outras formas de outorga da exploração da floresta pública às comunidades locais é sócio-ambiental, e o caráter da concessão florestal é predominantemente econômico-ambiental, o que faz com que o papel exercitado pelas comunidades locais seja diverso nas duas situações.

Se nas primeiras modalidades de exploração sustentável da floresta pública as comunidades locais figuram como beneficiárias de delegação gratuita para manutenção do ancestral modo de interação com o ecossistema do qual fazem parte, na concessão florestal tais comunidades, obrigatoriamente estruturadas como pessoas jurídicas, atuarão como empreendedores, empresários da floresta pública objeto da exploração, o que pode não significar o abandono dos aludidos modos tradicionais de interatividade com a floresta.

O segundo elemento do conceito legal é objetivo, o direito de praticar manejo florestal sustentável por meio da exploração de produtos e serviços de uma unidade de manejo.

Apesar da repetição de termos, o conceito delimita com certa precisão o referido objeto, até porque o manejo florestal sustentável também é conceituado pelo mesmo artigo $3^{\circ}$, inciso VI, da Lei Geral de Gestão de Florestas Públicas como sendo:

"administração da floresta para a obtenção de benefícios
econômicos, sociais e ambientais, respeitando-se os
mecanismos de sustentação do ecossistema objeto do
manejo e considerando-se, cumulativa e alternativamente, a
utilização de múltiplas espécies madeireiras, de múltiplos
produtos e subprodutos não madeireiros, bem como a
utilização de outros bens e serviços de natureza florestal".

É inegável que a administração da floresta de forma sustentada contempla a função sócio ambiental da propriedade e compatibiliza o desenvolvimento econômico com a conservação do meio ambiente, conforme os fundamentos dos artigos 170, incisos III e VI e artigo 225, ambos da Constituição Federal, sendo tais objetivos aplicáveis também ao uso da propriedade pública.

Tanto que, no conceito de manejo florestal sustentável retro transcrito, foram alinhavados dois aspectos indispensáveis para sua caracterização, a compatibilidade entre os benefícios econômicos e sociais decorrentes do uso com os mecanismos de sustentação do ecossistema objeto desse uso e a promoção do chamado uso múltiplo da floresta, adiante estudado. 
Em relação aos produtos e serviços florestais, a própria Lei Geral de Gestão de Florestas Públicas, também no artigo $3^{\circ}$, incisos III e IV, define que os primeiros são "produtos madeireiros e não madeireiros gerados pelo manejo florestal sustentável" e que os segundos é o "turismo e outras ações ou benefícios decorrentes do manejo e conservação da floresta, não caracterizados como produtos florestais".

Apesar da conceituação do serviço florestal de forma excludente, em relação aos produtos florestais, afere-se que o serviço florestal é uma atividade exercida na floresta e o produto florestal é uma coisa retirada da floresta, sejam ou não de origem madeireira.

Nesta senda, são objetos da exploração sustentável das florestas públicas os produtos e serviços florestais, ou seja, coisas (frutos, resinas, folhas etc) extraídas da floresta e atividades exercidas sobre elas.

Interessante notar que Gisele Ferreira de $\operatorname{Araujo}^{213}$ classifica o turismo ambiental como um serviço ambiental cultural. Além de tal categoria, os serviços ambientais seriam de provisão e de regulação. Explica a doutrinadora:

Os serviços ambientais são verdadeiramente essenciais, não somente para a redução da pobreza, mas principalmente para a sobrevivência humana.

Para efeitos de uma categorização, podemos classificar os serviços ambientais em serviços de provisão, serviços de regulação e serviços culturais.

Os serviços ambientais de provisão consistem nos produtos obtidos a partir dos ecossistemas como alimentos, águas, madeira, fibras, bioquímicos e recursos genéticos.

Os serviços de regulação podem ser descritos como aqueles benefícios obtidos pela regulação dos processos ecossistêmicos como, por exemplo, a regulação climática, a regulação de doenças a regulação hídrica, a purificação da água e a polinização.

Os serviços culturais são aqueles benefícios imateriais obtidos dos ecossistemas como o ecoturismo, a herança paisagística, cultural, religiosa, espiritual e educacional. (grifo nosso)

Da doutrina transcrita conclui-se que a doutrinadora denomina de serviços também aquilo que a Lei Geral de Gestão de Florestas Públicas qualifica de produtos florestais, em contraposição a serviços florestais e baliza como benefícios imateriais estes últimos.

\footnotetext{
${ }^{213}$ Estratégias de Sustentabilidade na Amazônia: aspectos científicos, sociais e legais, contexto global, visão
} comparativa. São Paulo: Editora Letras Jurídicas, 2008. p. 88. 
Em relação ao manejo florestal sustentável, para que a exploração da floresta assim seja considerada, também é indispensável, à luz do conceito legal, que ocorra sobre uma área pré-determinada denominada unidade de manejo, que, por seu turno, é conceituada no artigo $3^{\circ}$, inciso VIII, da Lei Geral de Gestão de Florestas Públicas, como:

\begin{abstract}
"perímetro definido a partir de critérios técnicos, socioculturais, econômicos e ambientais, localizado em florestas públicas, objeto de um Plano de Manejo Florestal Sustentável - PMFS, podendo conter áreas degradadas para fins de recuperação por meio de plantios florestais".
\end{abstract}

A unidade de manejo é delimitada por um plano de manejo florestal sustentável, documento técnico composto de várias fases e deve ter seu perímetro georreferenciado, estar incluída no cadastro de florestas públicas e no lote de concessão florestal, em atendimento ao artigo 14 da Lei Geral de Gestão de Florestas Públicas.

O regime de manejo florestal sustentável é um dos regimes de exploração de florestas e de formações sucessoras, tanto no domínio público, quanto no domínio privado, juntamente com o regime de supressão de florestas e formações sucessoras para uso alternativo do solo.

Esta é a classificação imposta pelo artigo $1^{\circ}, \S^{\circ}$, do Decreto $n^{\circ} 5.975$, de 30 de novembro de 2006, que regulamenta o Código Florestal.

No artigo $2^{\circ}$, desse mesmo decreto regulamentador, é previsto que toda exploração de florestas públicas e privadas sob o regime de manejo florestal sustentável depende de prévia aprovação do Plano de Manejo Florestal Sustentável - PMFS pelo órgão competente do Sistema Nacional do Meio Ambiente - SISNAMA.

No parágrafo único do mesmo dispositivo legal, o Plano de Manejo Florestal Sustentável é definido como documento técnico básico que contém as diretrizes e procedimentos para a administração da floresta, visando obter benefícios econômicos, sociais e ambientais.

Quanto ao elemento subjetivo do conceito legal de concessão florestal, constante no artigo $3^{\circ}$, inciso VII, da Lei Geral de Gestão de Florestas Públicas, o concessionário é definido como pessoa jurídica, em consórcio ou não.

No artigo $19, \S 1^{\circ}$, da Lei Geral de Gestão de Florestas Públicas, encontrase a regra de que somente empresas ou pessoas jurídicas constituídas sob as leis brasileiras e cujas sedes e administração estejam localizadas no Brasil, poderão ser habilitadas nas licitações para concessão florestal. 
As pessoas jurídicas em consórcio devem seguir as regras jurídicas básicas previstas no artigo 22, da Lei Geral de Gestão de Florestas Públicas e, caso entenda conveniente o poder concedente e esteja previsto no edital da licitação, deverão constituir empresa antes do entabulamento do contrato de concessão florestal, conforme artigo 23, da mesma lei.

Além disso, a Lei Geral de Gestão de Florestas Públicas traçou regras peculiares às empresas de pequeno porte e micro empresas, tais como no seu artigo $21, \S 3^{\circ}$, artigo 33 e artigo 74, atribuindo-lhes prerrogativas na licitação e no contrato de concessão florestal calcadas no princípio da igualdade material, incorporando-se também nesta lei o valor de se estimular o desenvolvimento de tais agentes econômicos.

No elemento temporal do conceito legal tem-se que não existe concessão florestal por prazo indeterminado, sendo que o artigo 35, da Lei Geral de Gestão de Florestas Públicas, impõe o prazo máximo de 40 (quarenta) anos, salvo na concessão florestal para exploração de serviços florestais, em que tal prazo máximo é reduzido pela metade.

A Lei Geral de Gestão de Florestas Públicas também impõe que o prazo mínimo da concessão florestal deve ser o de um ciclo de colheita ou exploração do produto (ou grupo de produtos), incluído no objeto da concessão, com ciclo mais longo.

$\mathrm{Na}$ concessão florestal para exploração de serviços florestais esse prazo mínimo é de 5 (cinco) anos, portanto não é definido em razão do ciclo de colheita ou exploração de produtos florestais incluídos no objeto da concessão.

Neste particular não se pode olvidar da definição do termo técnico "ciclo", constante no artigo $3^{\circ}$, inciso V, da Lei Geral de Gestão de Florestas Públicas: "período decorrido entre 2 (dois) momentos de colheita de produtos florestais numa mesma área”.

O regramento próprio da concessão florestal, último elemento da definição legal constante no artigo $3^{\circ}$, inciso VII, da Lei Geral de Gestão de Florestas Públicas, é sinalizado na expressão "que atenda às exigências do respectivo edital de licitação e demonstre capacidade para seu desempenho, por sua conta e risco".

A menção às regras do edital de licitação comprova a natureza jurídica contratual da concessão florestal.

A concessão florestal, como alhures citado neste texto, é espécie do gênero concessão de uso e, neste sentido, também opina Floriano Peixoto de Azevedo 
Marques Neto ${ }^{214}$ : "Embora ao definir essa modalidade de concessão pareça o legislador indicar que se trata de uma concessão de serviço público, analisando o seu regime jurídico concluímos tratar-se de uma concessão de uso de bem público.

Para ele, a dicção do artigo $3^{\circ}$, inciso VII, da Lei Geral de Gestão de Florestas Públicas ressaltou como objeto da outorga ao particular a atividade de manejo florestal sustentável.

Contudo, reconhece ele que o que se transfere ao particular é a "conservação e gestão do bem floresta pública", reforçando seu entendimento na doutrina alienígena de Nicola Centofanti ${ }^{215}$ sobre a "concessione di pascolo" do direito italiano, instituto bastante assemelhado à concessão florestal.

O doutrinador reforçou seu entendimento, ainda, com a lembrança do artigo 31, $3^{\circ}$, da Lei Geral de Gestão de Florestas Públicas, que determina a devolução da unidade de manejo ao poder concedente, pelo concessionário florestal, ao final do prazo da concessão florestal, nos termos do contrato, nada se disciplinando sobre a continuidade da atividade de manejo florestal sustentável, pois, para ele, “(...) justamente porque a utilidade concedida é a floresta (bem público) e não a atividade que viabiliza sua conservação".

Maria Luiza Machado Granziera ${ }^{216}$, além de vislumbrar a criação efetiva de uma política pública de gestão de florestas públicas brasileiras, também defende que a natureza jurídica da concessão florestal é de concessão de uso de bem público:

Trata-se da concessão de uso de bem público, para exploração dos recursos ambientais ali existentes, autorizada por ato do poder concedente, mediante a realização de processo licitatório - concorrência com outorga a título oneroso - regido pela Lei 8.666/91, que dispõe sobre normas gerais sobre licitações e contratos administrativos. (grifo nosso)

Vicente Gomes da Silva ${ }^{217}$ também defende que a concessão florestal possui natureza jurídica de concessão de uso de bem público, pois “(...) a concessão se expressa mediante contrato administrativo pelo qual a administração cede ao particular o uso de bem público, para que explore por determinado prazo e condições regulamentares”.

\footnotetext{
${ }^{214}$ O Regime Jurídico das Utilidades Públicas: função social e exploração econômica dos bens públicos. São Paulo, 2008, Tese de livre docência, Dada de defesa 02.10.2008, Faculdade de Direito da Universidade de São Paulo, p. 428

${ }^{215}$ I Beni Publici: Tutela Amministrativa e Giurisdizionale, Milão: Giuffrè, 2007. p. 206

${ }^{216}$ Mecanismos de efetividade da lei sobre florestas públicas, in Revista de Direito Ambiental, ano 13, n. 49, jan.-mar./2008, p. 201-216

217 Aspectos legais sobre a concessão de florestas públicas, in Fórum de Direito Urbano e Ambiental FDUA, Belo Horizonte, ano 5, n. 26, mar./abr. 2006, p. 3153-3156
} 
Júlio da Silveira Moreira ${ }^{218}$ entende que a concessão florestal é espécie de concessão de bem público, apesar de considerar que a Lei Geral de Gestão de Florestas Públicas adaptou tal instituto ao Direito Administrativo.

Posicionamento diferenciado é o de Rafael Véras de Freitas ${ }^{219}$ que, apesar de reconhecer a natureza jurídica contratual da concessão florestal, denominando-a de "contrato de manejo florestal”, não a considera uma concessão de uso de bem público e nem uma concessão de serviço público.

Para ele, trata-se a concessão florestal de um "contrato de exploração econômica - como, por exemplo, os contratos de exploração de petróleo e de energia elétrica (...)".

Esse entendimento não se coaduna com a própria natureza das obrigações assumidas pelo concessionário florestal, previstas principalmente nos artigos 31 a 35, da Lei Geral de Gestão de Florestas Públicas, que comprovam a sua natureza de concessão de uso de bem público, além da inexistência da figura do usuário da atividade de manejo florestal sustentável, que, também por isso, sequer se assemelha a um serviço público.

Portanto, entende-se que a natureza jurídica da concessão florestal é claramente de concessão de bem público, acrescentando-se apenas que o manejo florestal sustentável é uma espécie de uso qualificado do bem público florestal, por tal razão sendo relevante sua disciplina detalhada na lei regente da matéria.

Finalmente, ainda sobre a licitação para a concessão florestal, além das peculiaridades constantes nos artigos 19 a 26 da Lei Geral de Gestão de Florestas Públicas, é antecedida de uma série de medidas prévias relacionadas ao zoneamento e planificação da floresta pública e licenciamento ambiental da atividade de sua exploração, o que se detalha adiante.

\subsection{Medidas prévias à licitação para concessão florestal:}

José Roberto Dromi ${ }^{220}$ define a licitação da seguinte maneira:

(...) procedimento administrativo pelo qual um ente público, no exercício da função administrativa, abre a todos os

\footnotetext{
${ }^{218}$ A Lei de Florestas Públicas sob o crivo da Política Ambiental do Poder Público, in Revista CEJ, Brasília, Ano XII, n. 43, out./dez. 2008, p. 77-83

219 A concessão de florestas e o desenvolvimento sustentável, in Revista de Direito Público da Economia RDPE, Belo Horizonte, ano 7, n. 26, abr./jun. 2009, p. 107-133

${ }^{220}$ Licitación Pública, Buenos Aires: Ediciones Ciudad Argentina, 1995. p. 76
} 
interessados, que se sujeitem às condições fixadas no instrumento convocatório, a possibilidade de formularem propostas dentre as quais selecionará e aceitará a mais conveniente para a celebração do contrato. (grifo nosso)

Conforme a essência do próprio conceito apresentado, a licitação é um procedimento, um conjunto de atos administrativos voltados ao atingimento de uma finalidade, o estabelecimento de um contrato administrativo.

Para Maria Sylvia Zanella Di Pietro ${ }^{221}$, trata-se de procedimento "que exige uma sucessão de atos e fatos da Administração e atos e fatos do licitante" e para Maria Luiza Machado Granziera ${ }^{222}$, é um procedimento que "se desenvolve através de uma sucessão ordenada de atos vinculantes para a Administração e para os licitantes, de forma que todos tenham iguais oportunidades".

Edmir Netto de Araujo $^{223}$, para realçar tal idéia, relembra que a natureza da licitação é de ato administrativo decisório iniciado pela "autuação do procedimento", isto significando “(...) a formalização de atos (passos) em seqüência lógica, em direção ao provimento administrativo visado, sendo por vezes denominado processo administrativo quando o contraditório é previsto (...)" (itálico do original).

Todos os atos do citado procedimento são conduzidos pela Administração Pública, porém há um momento em que o são perante os administrados e com a participação destes.

Esse momento em que é dada a publicidade ao procedimento é o divisor das suas duas fases básicas, denominadas pela doutrina de fase interna e fase externa da licitação. $\mathrm{Na}$ fase interna, pode-se considerar que a Administração Pública ainda não instaurou o procedimento licitatório, o que é confirmado pelo magistério de Dora Maria de Oliveira Ramos ${ }^{224}$ :

O procedimento licitatório divide-se em duas grandes fases: uma interna, em que a Administração pratica uma série de atos preparatórios, como a definição do objeto, a autorização para licitar, a pesquisa de preços, a reserva de recursos necessários, a preparação do edital etc, superada essa fase, dá a Administração início a uma fase externa, para que os particulares interessados em participar do procedimento conheçam seus termos. Somente nesse momento, quando o edital é publicado ou são expedidos os convites respectivos,

\footnotetext{
${ }^{221}$ Op. cit. p. 367

${ }^{222}$ Aspectos jurídicos do saneamento, in Temas de Direito Ambiental e Urbanístico, Guilherme José Purvin de Figueiredo (org.), São Paulo: Max Limonad, 1998. p. 270.

${ }^{223}$ Curso de Direito Administrativo, São Paulo: Saraiva, 2005. p. 562

${ }^{224}$ Temas polêmicos sobre Licitações e Contratos, São Paulo: Malheiros Editores, 2000. p. 147
} 
pode-se considerar propriamente instaurada uma licitação. (grifo nosso)

Diante do transcrito conclui-se que o procedimento de licitação não se inicia, como diz o artigo 38, "caput", da Lei no 8.666, de 21 de junho de 1993 (Lei Geral de Licitações e Contratos Administrativos) e alterações posteriores, com a "abertura de processo administrativo, devidamente autuado, protocolado e numerado, contendo a autorização respectiva, a indicação sucinta de seu objeto e do recurso próprio para a despesa", além de outros documentos citados na lei.

O que disciplina o citado dispositivo legal é a abertura dos autos de registro dos atos que compõem o procedimento administrativo de licitação, sendo esta também a opinião de Maria Sylvia Zanella Di Pietro ${ }^{225}$, sendo a licitação instaurada após a publicação do extrato do instrumento convocatório ou expedição de carta convite.

Edmir Netto de Araujo $^{226}$ esclarece que na fase interna da licitação são juntados documentos como o ato de autorização da autoridade competente para sua abertura, projeto básico, orçamento detalhado de custos, para obras e serviços, adequada caracterização do objeto, no caso de compras e outras modalidades, indicação de reserva de recursos orçamentários, podendo haver já o empenhamento da despesa pública, pesquisa prévia de preços, realização de audiência pública na hipótese do artigo 39, da Lei Geral de Licitações e Contratos Administrativos.

Portanto, em qualquer modalidade de licitação é necessário que a Administração Pública adote uma série de atos "interna corporis" preparatórios da fase em que o procedimento deve se desenvolver perante os administrados.

Não se pode esquecer que mesmo nas hipóteses de contratação direta, por dispensa ou inexigibilidade de licitação, e de retardamento previsto no final do parágrafo único, do artigo $8^{\circ}$, da Lei Geral de Licitações e Contratos Administrativos, impõe-se a obrigação da Administração autuar e registrar atos do procedimento, principalmente para o atendimento de seu artigo 26.

Nesse dispositivo legal explicita-se a referida obrigação, com a finalidade de registro dos atos de justificativa da hipótese legal motivadora da contratação sem licitação prévia, ato de ratificação de autoridade superior, quando for o caso, caracterização de situação emergencial ou calamitosa, quando for o caso, documento de aprovação dos

${ }^{225}$ Op. cit., p. 368

${ }^{226}$ Loc. cit. 
projetos de pesquisa aos quais os bens serão alocados, razão da escolha do fornecedor ou executante e justificativa de preço.

Inegável, pelo conteúdo do dispositivo, que ao menos a manifestação de interesse público justificadora da escolha do fornecedor ou executante, a justificativa de preço, pela juntada de pesquisa prévia do produto ou serviço perante o mercado, além dos citados documentos de reserva orçamentária e prévio empenhamento, são documentos que devem compor os autos de registro de tal procedimento administrativo.

Vera Lúcia Machado D’Ávila ${ }^{227}$ entende que a justificativa de preço e demais hipóteses do dispositivo legal compõem "um mínimo exigido da autoridade contratante para dar seguimento e validade ao procedimento administrativo" e que há "claro comando normativo que demonstra que tais ocorrências (dispensa/inexigibilidade) não são sinônimo de isenção de um procedimento absolutamente formal que deve ser seguido pela Administração, sob pena de nulidade dos atos praticados” (grifo nosso).

Com isso tudo se demonstra que as regras gerais aplicáveis à licitação impõem à Administração Pública o dever de produzir procedimento administrativo composto por atos prévios à sua instauração e mesmo nas hipóteses em que a lei permite sua não realização.

Em relação à licitação para concessão florestal, disciplinada de forma específica pela Lei Geral de Gestão de Florestas Públicas, valem as mesmas regras gerais, acrescidas de outras obrigações em razão das especificidades do bem público florestal objeto da concessão.

O conjunto normativo aplicável à gestão das florestas públicas impõe algumas medidas prévias à licitação da concessão florestal, a saber:

a) formação do Cadastro Nacional de Florestas Públicas, gerido pelo Serviço Florestal Brasileiro - SFB;

b) elaboração de Plano Anual de Outorga Florestal proposto pelo Serviço Florestal Brasileiro e definido pelo Ministério do Meio Ambiente, no âmbito da União, além da elaboração de planos similares pelos Estados, Distrito Federal e Municípios;

c) licenciamento ambiental prévio à exploração de lotes ou unidades de manejo em áreas objeto de concessão florestal.

${ }^{227}$ Temas polêmicos sobre Licitações e Contratos, São Paulo: Malheiros Editores, 2000. p. 129 
As medidas prévias acima citadas relacionam-se diretamente com as atribuições dos órgãos gestores federal, estaduais e municipais, previstas no artigo 53, incisos I a IV, da Lei Geral de Gestão de Florestas Públicas.

Para melhor compreensão de tais medidas prévias, abordam-se cada uma delas nos tópicos seguintes.

\subsubsection{Formação do Cadastro Nacional de Florestas Públicas - CNFP:}

O artigo 54, da Lei Geral de Gestão de Florestas Públicas, criou na estrutura do Ministério do Meio Ambiente o Serviço Florestal Brasileiro, para atuação exclusiva na gestão das florestas públicas brasileiras.

Entre as competências de tal órgão público, encontra-se a prevista no artigo 54, inciso VII, da Lei Geral de Gestão de Florestas Públicas, de gerenciar o Cadastro Nacional de Florestas Públicas - CNFP, mantendo-o organizado e atualizado e adotar as medidas para interligá-lo aos cadastros estaduais e municipais.

O Cadastro Nacional de Florestas Públicas - CNFP, portanto, tem um caráter geral, é interligado ao Sistema Nacional de Cadastro Rural e integrado pelo Cadastro-Geral de Florestas Públicas da União e pelos cadastros de florestas públicas dos Estados, Distrito Federal e Municípios, conforme dispõe o artigo $2^{\circ}$, do Decreto $\mathrm{n}^{\circ} 6.063$, de 20 de março de 2007, Regulamento da Lei Geral de Gestão de Florestas Públicas, todos eles constituídos por bases de dados compartilhadas pelos diversos órgãos gestores das florestas públicas dos citados entes federativos.

Quanto ao Cadastro-Geral de Florestas Públicas da União, também gerido pelo SFB, é composto pelas áreas inseridas no Cadastro de Terras Indígenas, Unidades de Conservação federais, com exceção de áreas privadas localizadas em Unidades de Conservação que não exijam a desapropriação e florestas localizadas em imóveis urbanos ou rurais matriculados ou em processo de arrecadação em nome da União, autarquias, fundações, empresas públicas e sociedades de economia mista (artigo $2^{\circ}, \S 2^{\circ}$, da Lei Geral de Gestão de Florestas Públicas).

Neste particular merece menção a ilegalidade do referido decreto ao incluir no cadastro de florestas públicas aquelas localizadas em áreas sob o domínio de empresas públicas e sociedades de economia mista, uma vez que estes entes da administração indireta são regrados pelo regime jurídico de direito privado. 
Comentando a respeito do conceito de florestas públicas, constante no artigo $3^{\circ}$, inciso I, da Lei Geral de Gestão de Florestas Públicas, que indiscriminadamente conferiu a todas as entidades da administração indireta a titularidade de tais florestas, Floriano Peixoto de Azevedo Marques Neto ${ }^{228}$ criticou tal dispositivo legal anotando que "É certo haver aqui uma pequena impropriedade técnica. Por entes da administração indireta, aqui, entendemos aqueles com personalidade jurídica de direito público".

Portanto, clara a ocorrência de vício de excesso de poder regulamentar pelo Chefe do Poder Executivo, pois desbordou dos limites da lei regulamentada pelo ato administrativo normativo, incluindo expressamente as florestas localizadas em áreas de propriedade de pessoas jurídicas de direito privado no Cadastro-Geral de Florestas Públicas da União.

O decreto regulamentar não é meio hábil para modificar o regime jurídico de direito público para somente determinados bens de uma pessoa jurídica da administração pública indireta regida pelo direito privado.

Quanto à inclusão de florestas públicas em áreas militares, reza o artigo $2^{\circ}, \S 3^{\circ}$, do Regulamento da Lei Geral de Gestão de Florestas Públicas, que depende de autorização do Ministério da Defesa.

No Cadastro-Geral de Florestas Públicas da União são incluídas florestas públicas em três estágios, a saber: de identificação, de delimitação e de demarcação.

No estágio de identificação constam apenas os polígonos georreferenciados de florestas, plantadas ou naturais, localizadas em terras de domínio da União

No estágio de delimitação os polígonos de florestas públicas federais são averbados nas matrículas dos imóveis públicos.

No estágio de demarcação, os polígonos de florestas públicas são materializados no campo e os dados georreferenciados inseridos no citado cadastro.

Note-se que esses estágios nada mais são do que fases do procedimento de georreferenciamento inaugurado pelo artigo $3^{\circ}$, da Lei $\mathrm{n}^{\circ} 10.267$, de 28 de agosto de 2001, que modificou a redação do artigo $176, \S 3^{\circ}$, da Lei $n^{\circ} 6.015$, de 31 de dezembro de 1973 , que dispõe sobre Registros Públicos.

Tal procedimento foi instituído com a finalidade de dar maior confiabilidade ao registro público de terras rurais brasileiras, exigindo que a identificação

${ }^{228}$ Op. cit., p. 429 
de imóveis rurais desmembrados, parcelados ou remembrados em registros públicos seja acompanhada de um memorial descritivo, assinado por profissional habilitado e com a devida Anotação de Responsabilidade Técnica - ART.

O referido memorial descritivo das áreas dos imóveis rurais, ainda segundo a norma, deve conter todas as coordenadas dos vértices que definem os seus limites, georreferenciadas ao Sistema Geodésico Brasileiro e com precisão posicional a ser fixada pelo Instituto Nacional de Colonização e Reforma Agrária - INCRA.

Segundo o artigo $5^{\circ}$, do Regulamento da Lei Geral de Gestão de Florestas Públicas, é competência do Serviço Florestal Brasileiro manter em seus arquivos imagens de satélite e outras formas de sensoriamento remoto que tenham coberto o território nacional desde o ano de 2006, podendo incluir no Cadastro-Geral de Florestas Públicas da União áreas degradadas localizadas nos polígonos de florestas públicas federais, conforme artigo $6^{\circ}$, parágrafo único, do mesmo regulamento.

O Cadastro-Geral de Florestas Públicas da União, segundo determina o artigo $7^{\circ}$, do Regulamento da Lei Geral de Gestão de Florestas Públicas, deve conter informações sobre os dados fundiários do imóvel recoberto pela floresta pública, ressaltando-se:

a) número de matrícula do imóvel no cartório de registro de imóveis, Município e Estado de localização, titular e gestor da floresta;

b) polígono georreferenciado do imóvel;

c) descrição do bioma, tipo e aspectos da cobertura florestal;

d) referências de estudos associados à floresta pública que envolvam recursos naturais renováveis e não-renováveis relativos aos limites da floresta, uso e destinação comunitários;

e) pretensões de posse eventualmente incidentes sobre a área;

f) existência de conflitos fundiários ou sociais;

g) atividades desenvolvidas, certificações, normas, atos, contratos administrativos e cíveis incidentes nos limites da floresta;

h) recomendações de uso formuladas pelo Zoneamento Ecológico Econômico do Brasil.

No artigo $9^{\circ}$, do Regulamento da Lei Geral de Gestão de Florestas Públicas, é previsto que as florestas públicas federais não destinadas a manejo florestal ou para criação de Unidades de Conservação são impossibilitadas de conversão para o uso alternativo do solo até que seja recomendado pelo Zoneamento Ecológico Econômico, esteja oficializada e a conversão seja plenamente justificada nos termos do artigo 72 da Lei 
Geral de Gestão de Florestas Públicas. Tal dispositivo do decreto simplesmente reproduziu o conteúdo do citado artigo da lei.

Porém, merece esclarecimento o que significa o uso alternativo do solo, que é definido no artigo $10, \S 1^{\circ}$, do Decreto $n^{\circ} 5.975$, de 30 de novembro de 2006, da seguinte forma: "Entende-se por uso alternativo do solo a substituição de florestas e formações sucessoras por outras coberturas do solo, tais como projetos de assentamento para reforma agrária, agropecuários, industriais, de geração e transmissão de energia, de mineração e de transporte".

Desta forma, o uso alternativo do solo significa a supressão total da floresta ou formação sucessora para que a área possa ser usada conforme os fins estabelecidos na referida norma.

Deve-se notar, também, que pelo artigo 73, da Lei Geral de Gestão de Florestas Públicas, foram excluídas de concessões florestais áreas que, na data da promulgação da citada lei, estivessem ocupadas e convertidas para o uso alternativo do solo, desde que esta vocação fosse confirmada no Zoneamento Ecológico-Econômico.

Mesmo as florestas públicas não incluídas no Cadastro-Geral de Florestas Públicas da União não perdem a proteção conferida pela Lei Geral de Gestão de Florestas Públicas, assim dispondo o artigo 11, de seu decreto regulamentar.

O Cadastro Nacional de Florestas Públicas, pelo até aqui abordado, é instrumento indispensável à concretização de concessões florestais, na medida em que a União e demais entes federativos, ao organizarem tais cadastros, possibilitam maior racionalização, organização e integração das citadas concessões aos demais instrumentos de gestão dos recursos ambientais do país.

\subsubsection{Elaboração de Plano Anual de Outorga Florestal - PAOF:}

Outra providência específica que o poder concedente deve implementar antes da abertura da licitação para concessão florestal é a prevista no artigo 10, da Lei Geral de Gestão de Florestas Públicas, a definição do Plano Anual de Outorga Florestal PAOF.

Esse plano é basicamente uma relação de todas as florestas públicas que serão submetidas ao processo de concessão florestal no ano em que vigorar e deve ser concluído até o dia 31 de julho do ano anterior, em conformidade com os prazos para a 
elaboração da lei orçamentária anual, nos termos do artigo 23, do Decreto $n^{\circ} 6.063$, de 20 de março de 2007 (Regulamento da Lei Geral de Gestão de Florestas Públicas).

No caso da União, conforme o $\S 1^{\circ}$, do aludido dispositivo, compete à Secretaria de Patrimônio da União, do Ministério do Planejamento, Orçamento e Gestão a manifestação sobre a inclusão de determinada área florestal federal no referido plano e, ao Conselho de Defesa Nacional, conforme o $§ 3^{\circ}$, a apreciação da inclusão de áreas situadas na faixa de fronteira.

A faixa de fronteira, definida no artigo $20, \S 2^{\circ}$, da Constituição Federal é de até cento e cinqüenta quilômetros de largura, ao longo das fronteiras terrestres, considerada fundamental para defesa do território nacional.

Vislumbra-se no Plano Anual de Outorga Florestal a natureza jurídica de planejamento voltada a um zoneamento ambiental, em que pese o fato de incidir exclusivamente sobre áreas públicas recobertas por florestas, decorrendo, portanto, da competência geral prevista no artigo 21, inciso IX, da Constituição Federal, no sentido da União ter que elaborar e executar planos nacionais e regionais de ordenação do território e de desenvolvimento econômico e social.

A planificação (ou planejamento) e zoneamento são atividades promovidas pela Administração Pública tradicionalmente na ordenação do espaço público e privado existentes nas cidades, tanto que, no artigo $4^{\circ}$, da Lei $n^{\circ} 10.257$, de 10 de julho de 2001 (Estatuto das Cidades), são tais atividades incluídas como instrumentos da Política Urbana.

No âmbito do Direito Urbanístico, denota-se que a atividade de planificação e zoneamento são oriundas do exercício do poder de polícia do Estado, com duas vertentes bastante claras, repartição do solo urbano e designação de seu uso.

Tal lógica pode ser transferida ao âmbito da ordenação do uso dos recursos do meio ambiente natural, idéia esta defendida também por Celso Antonio Pacheco Fiorillo ${ }^{229}$ : "Descendo a detalhes, podemos verificar que o zoneamento ambiental possui apenas uma diferença de enfoque do urbano, uma vez que o objetivo daquele é a proteção do meio ambiente, de modo que o uso permitido será estritamente limitado." e "Zonear significa repartir o solo e dar a este determinada designação de uso".

Confirma a doutrina de Paulo Affonso Leme Machado ${ }^{230}$ que planejamento e zoneamento são atividades correlatas e interdependentes: "O zoneamento

\footnotetext{
${ }^{229}$ Curso de Direito Ambiental Brasileiro, São Paulo: Saraiva, 2008. p. 111 e 332
}

${ }^{230}$ Direito Ambiental Brasileiro, São Paulo: Malheiros, 2007. p. 188 
deve ser conseqüência de um planejamento. Um planejamento mal-estruturado, malfundamentado, poderá ensejar um zoneamento incorreto e inadequado.”.

José Afonso da Silva ${ }^{231}$ arremata, em relação ao zoneamento ambiental, anotando sua semelhança com o zoneamento urbano e ressaltando sua função ambiental, da seguinte forma:

(...) podemos, grosso modo, dizer que se trata de um procedimento por meio do qual se instituem zonas de atuação especial com vistas à preservação, melhoria e recuperação da qualidade ambiental. Não difere essencialmente do Zoneamento Urbano, que também tem função ambiental. Em essência, identificam-se no fato de que são ambos zoneamento de uso do solo. A diferença é apenas de enfoque, está apenas no fato de que o objetivo do Zoneamento Ambiental é primordialmente a proteção do meio ambiente, de sorte que o uso aí permitido será estritamente limitado. Ambos constituem, pois, disciplina de uso do solo particular. (itálico do original, grifo nosso)

Neste caminho, pode-se defender que, apesar do PAOF ser constituído somente por áreas sob o domínio público, trata-se efetivamente de zoneamento e planificação das florestas que recobrem tais áreas visando o uso sustentado pelos futuros concessionários.

O objetivo do PAOF é semelhante ao de qualquer plano em que o uso é ordenado pela fixação de diferentes áreas, com diferentes finalidades.

Comprova a natureza de zoneamento ambiental do PAOF o conteúdo do artigo 11 e seus parágrafos, da Lei Geral de Gestão de Florestas Públicas, que condiciona a União, na elaboração de seu PAOF, a considerar as políticas e o planejamento para o setor florestal, a reforma agrária, a regularização fundiária, a agricultura, o meio ambiente, os recursos hídricos, o ordenamento territorial e o desenvolvimento regional, o Zoneamento Ecológico-Econômico nacional e estadual e demais instrumentos que disciplinam o uso, a ocupação e exploração dos recursos ambientais e os planos de outorga dos Estados, Distrito Federal e Municípios.

Cabível a consideração sobre o Zoneamento Ecológico Econômico, que é de caráter nacional e foi instituído pelo Decreto $\mathrm{n}^{\mathrm{o}} 4.297$, de 10 de julho de 2002, para regulamentar o artigo $9^{\circ}$, inciso II, da Lei $\mathrm{n}^{\circ}$ 6.938, de 31 de agosto de 1981 (Lei da Política Nacional do Meio Ambiente) e que, segundo Luís Paulo Sirvinskas ${ }^{232}$, é

${ }^{231}$ Direito Ambiental Constitucional, São Paulo: Malheiros, 2000. p. 239

${ }^{232}$ Manual de Direito Ambiental, São Paulo: Saraiva, 2008. p. 146 
"instrumento de organização do território a ser obrigatoriamente seguido na implantação de planos, obras e atividades públicas e privadas", pois estabelece uma série de medidas e padrões de proteção ambiental destinados a assegurar a qualidade ambiental, dos recursos hídricos, do solo e o desenvolvimento sustentável.

Ainda, nos mesmos dispositivos da Lei Geral de Gestão de Florestas Públicas, impõe-se à União, quando da elaboração do PAOF, a obrigação dele excluir áreas das unidades de conservação de proteção integral, das reservas de desenvolvimento sustentável, das reservas extrativistas, das reservas de fauna e das áreas de relevante interesse ecológico, salvo para áreas em que o plano de manejo da unidade de conservação permita a atividade de concessão florestal.

O Plano Anual de Outorga Florestal, em atendimento ao artigo $11, \S 1^{\circ}$ da Lei Geral de Gestão de Florestas Públicas, deverá contemplar os planos similares dos Estados, Distrito Federal e Municípios, nisto espelhando-se a necessidade de integração dos entes públicos, encaminhados até o dia 30 de junho de cada ano, sob pena de ser considerado somente no plano do ano seguinte (artigo $23, \S \S 1^{\circ}$ e $2^{\circ}$, do Regulamento da Lei Geral de Gestão de Florestas Públicas).

Entende-se que as citadas limitações impostas pela Lei Geral de Gestão de Florestas Públicas, quanto às áreas que devem ou não figurar no Plano Anual de Outorga Florestal, devem ser aplicadas por simetria aos planos similares desenvolvidos pelos Estados, Distrito Federal e Municípios, com suas devidas adaptações, o que comprova o caráter geral da Lei.

O Plano Anual de Outorga Florestal também deve ser instrumento complementar ao Cadastro Nacional de Florestas Públicas, analisado no tópico anterior, pois naquele só poderão ser incluídas as florestas públicas devidamente identificadas neste, nos termos da regra do artigo 19, parágrafo único, do Regulamento da Lei Geral de Gestão de Florestas Públicas.

O conteúdo mínimo do Plano Anual de Outorga Florestal, conforme artigo 20, do Regulamento da Lei Geral de Gestão de Florestas Públicas, deve ser composto por: a) identificação do total de florestas públicas constantes do Cadastro-Geral de Florestas Públicas da União;

b) área total já submetida a concessões florestais federais e previsão de produção dessas áreas;

c) identificação da demanda por produtos e serviços florestais; 
d) identificação da oferta de produtos e serviços oriundos do manejo florestal sustentável nas regiões que abranger, incluindo florestas privadas, florestas destinadas às comunidades locais e florestas públicas submetidas à concessão florestal;

e) identificação georreferenciada das florestas públicas federais passíveis de serem submetidas a processo de concessão florestal, durante o período de sua vigência;

f) identificação georreferenciada das terras indígenas, das unidades de conservação, das áreas destinadas às comunidades locais, áreas prioritárias para recuperação e áreas de interesse para criação de unidades de conservação de proteção integral, que sejam adjacentes às áreas destinadas à concessão florestal federal;

g) compatibilidade com outras políticas setoriais; descrição da infra-estrutura, condições de logística, capacidade de processamento e tecnologia existentes nas regiões por ele abrangidas;

h) indicação de adoção de mecanismos de acesso democrático às concessões florestais, pela explicitação das regras de definição das unidades de manejo e do percentual máximo de área de concessão florestal que um concessionário, individualmente ou em consórcio, poderá deter relativo à área destinada à concessão florestal no Plano Anual de Outorga Florestal vigente e executados nos anos anteriores;

i) descrição das atividades previstas para o seu período de vigência, em especial aquelas relacionadas à revisão de contratos, monitoramento, fiscalização e auditorias;

j) previsão dos meios necessários para sua implementação, incluindo recursos humanos e financeiros, por meio de consideração na elaboração do projeto de lei orçamentária anual, enviado ao Congresso Nacional a cada ano.

Do conteúdo mínimo do Plano Anual de Outorga Florestal, comprova-se que é planejamento e zoneamento ambiental florestal que contempla aspectos técnicos e econômicos que são indispensáveis ao sucesso da concessão florestal.

Primeiramente, confirma a natureza de zoneamento as obrigações dos itens e) e f) supra, referentes a identificação de florestas públicas federais passíveis de submissão a concessão florestal, combinada com a identificação de terras indígenas, de unidades de conservação, das áreas destinadas ao uso de comunidades locais, das áreas prioritárias para recuperação e de áreas de interesse para criação de unidades de conservação de proteção integral adjacentes àquelas primeiras.

Isto demonstra que a preocupação do legislador em ordenar a exploração das florestas públicas por concessão florestal de forma concatenada ao uso das áreas adjacentes para outras finalidades de conservação e preservação. 
A atenção ao aspecto econômico, indispensável à viabilidade, eficiência e eficácia da concessão florestal, pode ser vislumbrada nas obrigações dos itens b), c), d) e g) supra, principalmente na previsão de produção das áreas de concessão florestal, a identificação da oferta e demanda por produtos e serviços florestais, descrição da infraestrutura, condições de logística, capacidade de processamento e tecnologia existentes nas regiões abrangidas no Plano Anual de Outorga Florestal.

A preocupação com o acesso democrático às concessões florestais também foi incluída como conteúdo mínimo do Plano Anual de Outorga Florestal, até para que se faça valer o que prevê o artigo 34, da Lei Geral de Gestão de Florestas Públicas.

Em tal dispositivo legal foram previstas medidas de proteção da concorrência, salvaguardas para se evitar a concentração econômica no âmbito das concessões florestais.

As aludidas salvaguardas são de duas naturezas, a primeira de proibição de outorga a cada concessionário, individualmente ou em consórcio, mais de dois contratos em cada lote de concessão florestal e a segunda, de fixação de um limite percentual máximo de área de concessão florestal para cada concessionário, individual ou em consórcio.

No Plano Anual de Outorga Florestal devem também, conforme referido, haver consideração sobre as áreas de convergência com outros setores, sendo que no artigo 22, do Regulamento da Lei Geral de Gestão de Florestas Públicas, se definiu que devem ser considerados os contratos de concessão, autorizações, licenças e outorgas para mineração, petróleo, gás, estradas, linhas de transmissão, geração de energia, oleodutos, gasodutos e para o uso da água para tal fim.

Finalmente, no Plano Anual de Outorga Florestal também deverão ser definidas unidades de manejo pequenas, médias e grandes, baseadas em critérios técnicos que atendam peculiaridades regionais, considerando os parâmetros de área necessária para completar um ciclo de produção da floresta para os produtos manejados, a estrutura, porte e capacidade dos agentes envolvidos na cadeia produtiva, conforme artigo 24 , do Regulamento da Lei Geral de Gestão de Florestas Públicas.

Esta regra visa dar efetividade ao que prevê o artigo 33, da Lei Geral de Gestão de Florestas Públicas, que garante o direito de acesso às concessões florestais por pessoas jurídicas de pequeno porte, micro e médias empresas.

De tudo o que foi estudado, conclui-se que o Plano Anual de Outorga Florestal é providência prévia à licitação para concessão florestal que lhe confere a 
sustentabilidade, pois em tal documento são insertas normas de caráter ambiental, social e econômico que podem garantir a viabilidade da concessão florestal.

Finalmente, impõe o artigo 75, da Lei Geral de Gestão de Florestas Públicas, que, após 5 (cinco) anos da implantação do primeiro Plano Anual de Outorga Florestal, deverá ser realizada uma avaliação sobre os aspectos técnicos, econômicos, sociais e ambientais da aplicação da referida lei, dando-se publicidade.

\subsubsection{Licenciamento ambiental:}

O licenciamento ambiental é definido no artigo $1^{\circ}$, inciso I, da Resolução CONAMA nº 237, de 19 de dezembro de 1997, como:

(...) procedimento administrativo pelo qual o órgão ambiental competente licencia a localização, instalação, ampliação e a operação de empreendimentos e atividades utilizadoras de recursos ambientais, consideradas efetiva ou potencialmente poluidoras ou daquelas que, sob qualquer forma, possam causar degradação ambiental, considerando as disposições legais e regulamentares e as normas técnicas aplicáveis ao caso" (grifo nosso).

Para Celso Antonio Pacheco Fiorillo ${ }^{233}$, o licenciamento ambiental é “(...) o complexo de etapas que compõe o procedimento administrativo, o qual objetiva a concessão de licença ambiental. Dessa forma, não é possível identificar isoladamente a licença ambiental, porquanto é uma das fases do procedimento".

A definição de Luís Paulo Sirvinskas ${ }^{234}$ é a seguinte: “(...) sucessão de atos concatenados com o objetivo de alcançar uma decisão final externada pela licença ambiental (licença prévia, de instalação e de operação)".

E, Luis Manuel Fonseca Pires ${ }^{235}$ entende que o licenciamento ambiental deve ser compreendido como:

(...) processo administrativo que precede a emissão do ato de licença ou do ato de seu indeferimento, e por isto deve observar os princípios constitucionais referentes ao contraditório e à ampla defesa (art. 5', LIV e LV, da Constituição Federal) em relação aos atos praticados durante o procedimento que possam interferir substancialmente na apreciação do pedido, como ocorre com o estudo de impacto

\footnotetext{
233 Op. cit., p. 91

${ }^{234}$ Op. cit. , p. 156

${ }^{235}$ Regime Jurídico das Licenças, São Paulo: Quartier Latin, 2006. p. 112
} 
ambiental (art. 225, $\S 1^{\circ}$, IV da Constituição Federal) e as audiências públicas (...)" (grifo nosso)

De todas as definições desfiladas conclui-se que o licenciamento ambiental é um procedimento administrativo, portanto um conjunto de atos administrativos logicamente organizados para o atingimento de uma finalidade, a emissão de uma licença ambiental.

A licença ambiental, por sua vez, é definida no artigo $1^{\circ}$, do inciso II, da Resolução CONAMA nº 237, de 19 de dezembro de 1997, da seguinte forma:

(...) ato administrativo pelo qual o órgão ambiental competente, estabelece as condições, restrições e medidas de controle ambiental que deverão ser obedecidas pelo empreendedor, pessoa física ou jurídica, para localizar, instalar, ampliar e operar empreendimentos ou atividades utilizadoras dos recursos ambientais consideradas efetiva ou potencialmente poluidoras ou aquelas que, sob qualquer forma, possam causar degradação ambiental. (grifo nosso)

O conceito legal supra transcrito apenas explicita dois aspectos de tal ato administrativo:

a) seu conteúdo unilateral, de estabelecimento de condições e medidas de controle ambiental que devem ser observadas pelo particular (empreendedor), seu destinatário;

b) seu objeto de facultar ao particular o exercício de uma atividade.

Portanto, tal conceito diretamente não expõe se a natureza da licença ambiental é discricionária ou vinculada, o que gera discussão doutrinária quanto ao sua inserção nos gêneros licença ou autorização.

Nesta discussão, Paulo Affonso Leme Machado ${ }^{236}$ contribui com a idéia de que "Licença e autorização - no Direito brasileiro - são vocábulos 'empregados sem rigor técnico'. O emprego na legislação e na doutrina do termo 'licenciamento' ambiental não traduz necessariamente a utilização da expressão jurídica licença, em seu rigor técnico.".

Ainda, ele entende que “(...) razoável é concluir que o sistema de licenciamento ambiental passa a ser feito pelo sistema de autorizações, conforme entendeu o texto constitucional", motivo pelo qual adotou em sua obra como "equivalente" as expressões "licenciamento ambiental" e "autorização ambiental" (grifo nosso).

\footnotetext{
${ }^{236}$ Direito Ambiental Brasileiro, São Paulo: Malheiros, 2007. p. 273
} 
Tal doutrinador, portanto, entende que sempre há discricionariedade da Administração Pública na outorga de uma licença ambiental.

Celso Antonio Pacheco Fiorillo ${ }^{237}$, noutra direção, entende que a licença ambiental pode possuir caráter discricionário "sui generis" ou vinculado a depender do resultado do Estudo Prévio de Impacto Ambiental - EPIA e do Relatório de Impacto Ambiental - RIMA decorrente.

$\mathrm{Na}$ sua maneira de ver, defende Celso Antonio Pacheco Fiorillo ${ }^{238}$ que “(...) a licença ambiental - enquanto licença - deixa de seu um ato vinculado para ser um ato com discricionariedade sui generis (...)”, pois “(...) a existência de um EIA/RIMA favorável condiciona a autoridade à outorga da licença ambiental, existindo, dessa feita, o direito de o empreendedor desenvolver sua atividade econômica. Temos nessa hipótese o único caso de uma licença ambiental vinculada.” e “(...) se o EIA/RIMA mostra-se desfavorável, totalmente ou em parte, caberá à Administração, segundo critérios de conveniência e oportunidade, avaliar a concessão ou não da licença ambiental (...) Essa possibilidade retrata uma discricionariedade sui generis." (itálico do original, grifo nosso).

Luís Paulo Sirvinskas ${ }^{239}$ entende que “(...) a licença ambiental não pode ser considerada mera autorização ou permissão nos termos do direito administrativo", porque o estabelecimento de um prazo determinado, apesar de não lhe conferir um caráter de definitividade, visa dar segurança ao empreendedor para não ficar "a mercê da mudanças políticas ou da vontade da Administração Pública, que poderia revogar ou cassar a licença a qualquer momento". E, assim a conceitua: "Ela é espécie de ato administrativo negocial, concedido pela Administração Pública por prazo determinado, podendo ser revogado se a empresa ou atividade estiver causando prejuízo à saúde humana, danos ao meio ambiente ou descumprir as determinações legais ou regulamentares".

Márcia Walquiria Batista dos $\operatorname{Santos}^{240}$, ao analisar a licença em matéria ambiental, anotou que:

(...) na quase totalidade, as denominadas licenças representam autorização, permissão ou concessão. Se se trata de exploração e utilização de bens ambientais, poderse-á não estar diante de uma licença. Não há, em geral, direito subjetivo e direito adquirido, em matéria ambiental, o que nos faz concluir que a anuência do Poder Público poderá

\footnotetext{
${ }^{237}$ Op. cit., p. 92

${ }^{238}$ Loc. cit.

${ }^{239}$ Op. cit., p. 160

${ }^{240}$ Licença Urbanística, São Paulo: Malheiros, 2001. p. 41
} 
dar guarida, mais freqüentemente, a outros institutos afins $\mathrm{e}$ de forma muito ocasional, à licença. (...) (grifo nosso)

Para a doutrinadora ${ }^{241}$, em Direito Ambiental existem diversos tipos de licenças, as mais complexas, que exigem o EIA/RIMA, e as menos complexas, para outros atos que não dependem do EIA/RIMA, como, por exemplo, "caçar, pescar, penetrar nas florestas etc".

Para as primeiras, mais complexas, “(...) não seria razoável pressupor que existindo um EIA/RIMA aprovado, pudesse a Administração negar-se a expedir o alvará. Aqui se trata, portanto, de um ato final caracterizado como licença".

Para as demais, menos complexas, é possível configurarem autorizações e não licenças.

Márcia Walquiria Batista dos Santos ${ }^{242}$ realça que o critério diferenciador por ela utilizado em seu magistério “(...) é o mesmo que utilizamos para a licença urbanística - preexistência de direito subjetivo à emissão do alvará" (grifo nosso).

O magistério citado assemelha-se muito ao de José Afonso da Silva ${ }^{243}$, para quem só pode ser considerada licença o ato administrativo aplicável “(...) naquelas hipóteses em que preexiste o direito subjetivo ao exercício da atividade. Se esse direito não existe, se o exercício da atividade vai nascer com o ato da autoridade, então este não será licença.”. Para ele, ainda, a autorização:

(...) não pressupõe um direito anterior a ser exercido. Vale dizer, o direito ao exercício da atividade autorizada nasce com a outorga da autorização. Ao contrário, ela pressupõe uma proibição geral, expressa ou decorrente do sistema, ao exercício da atividade. Sua outorga consiste, assim, em remover esse obstáculo em favor de alguém, por razões de conveniência ou de mera liberalidade da Administração.

Por meio deste critério, o doutrinador analisa o termo licença em cada situação prevista na legislação ambiental para confirmar, caso a caso, a sua natureza jurídica de licença ou de autorização, não estabelecendo "a priori” uma natureza específica para a licença ambiental.

\footnotetext{
${ }^{241}$ Op. cit., p. 43

${ }^{242}$ Loc. cit.

${ }^{243}$ Op. cit. p. 244
} 
Em sentido contrário, Luis Manuel Fonseca Pires ${ }^{244}$, considera que a licença ambiental, sem delimitar situações específicas, subsiste como ato vinculado, pois possui todos os traços que delimitam gênero licença no Direito Administrativo:

E tal como as licenças urbanísticas têm uma dimensão coletiva (...) que ainda mais legitima a estipulação de prazos de eficácia dos atos administrativos que são emitidos, também para as licenças ambientais, em razão da incontrastável importância de âmbito difuso que representa o meio ambiente, justifica-se a fixação de lapsos de eficácia destes atos.

No entender desse doutrinador ${ }^{245}$, as licenças ambientais, tal como as licenças urbanísticas, são caracterizadas por serem usadas como "instrumentos para relações de sujeição geral: para o exercício das limitações administrativas à liberdade e à propriedade ('poder de polícia').".

Sem demérito aos posicionamentos dos doutrinadores, melhor caminho para a compreensão da natureza jurídica das licenças ambientais é analisar o direito subjetivo que detém o particular, objeto de reconhecimento pela Administração Pública na emissão do ato administrativo que permite o seu exercício, cumpridas determinadas condições previstas na lei.

O direito subjetivo é o da exploração sustentável do meio ambiente, que deve ser aferida pela Administração Pública pelo procedimento de licenciamento ambiental, onde pode se inserir outros instrumentos como, por exemplo, o estudo prévio de impacto ambiental, o relatório de impacto ambiental etc.

Assim, demonstrada a sustentabilidade da exploração por intermédio de um estudo prévio de impacto ambiental favorável, confirmado está o direito subjetivo a ser reconhecido pela licença ambiental.

Em caso contrário, se o estudo prévio de impacto ambiental for desfavorável e houver decisão da Administração Pública no sentido de outorgar a licença ambiental, ao contrário do que defende Celso Antonio Pacheco Fiorillo, não houve discricionariedade, mas sim confirmação da vinculação, pois esta teve que demonstrar a inconsistência do referido instrumento, substituindo-o por sua decisão motivada, decisão esta que deve demonstrar a sustentabilidade da atividade objeto da licença ambiental.

${ }_{245}^{244}$ Op. cit., p. 112

${ }^{245}$ Op. cit., p. 19 
A vinculação, ao contrário do raciocínio do referido doutrinador, não reside na obrigatória observância do Estudo Prévio de Impacto Ambiental - EPIA, mas na demonstração de que a atividade do particular não causará degradação ambiental, independentemente do instrumento de tal demonstração.

Quanto às demais situações, em que a licença ambiental não depende de estudo prévio de impacto ambiental, em situações em que a Administração Pública faculta ao particular o exercício de uma atividade genericamente proibida, o conteúdo da licença ambiental é, na verdade, de autorização.

Portanto, considera-se que só pode ser considerada licença ambiental aquela decorrente de licenciamento ambiental, não havendo razão para a adoção da dicotomia elaborada por Celso Antonio Pacheco Fiorillo.

Em relação à dicotomia desenhada por Márcia Walquiria Batista dos Santos, baseada na doutrina de José Afonso da Silva, entende-se que é servível na apreciação da natureza jurídica de atos de outorga de direito ao particular, em relação ao meio ambiente, em situações específicas disciplinadas pela legislação ambiental, pois, em muitos casos, esta pode disciplinar uma hipótese de autorização, porém erroneamente nominando-a de licença.

Ainda, para melhor enfrentamento do tema no âmbito específico da exploração de florestas públicas, não se pode olvidar que existem três espécies de licenças ambientais, que podem ser expedidas isolada ou sucessivamente, de acordo com a natureza, características e fase do empreendimento ou atividade previstas no artigo $8^{\circ}$, da Resolução CONAMA nº 237, de 19 de dezembro de 1997, a saber:

a) licença prévia (LP): concedida na fase preliminar do planejamento do empreendimento ou atividade, para aprovar a localização e concepção, atestar a viabilidade ambiental e estabelecer os requisitos básicos e condicionantes a serem atendidos nas próximas fases de sua implementação, com prazo de validade máximo de cinco anos;

b) licença de instalação (LI): autoriza a instalação do empreendimento ou atividade, de acordo com as especificações constantes dos planos, programas e projetos aprovados, incluindo as medidas de controle ambiental e demais condicionantes, da qual constituem motivo determinante, com prazo máximo de validade de seis anos;

c) licença de operação (LO): autoriza a operação da atividade ou empreendimento, após a verificação do efetivo cumprimento do que consta das licenças anteriores, com as medidas de controle ambiental e condicionantes determinados para a operação, com prazo de validade mínimo de quatro e máximo de dez anos. 
Os estudos ambientais devem ser definidos pelo órgão ambiental em conjunto com o empreendedor, antes do início do processo de licenciamento ambiental da licença requerida, conforme artigo 10, inciso I, do aludido ato administrativo normativo, sendo esta uma regra geral.

No artigo $1^{\circ}$, inciso III, da Resolução CONAMA n 237, de 19 de dezembro de 1997, é conceituado o gênero "estudos ambientais", como "todos e quaisquer estudos relativos aos aspectos ambientais relacionados à localização, instalação, operação e ampliação de uma atividade ou empreendimento, apresentado como subsídio para a análise da licença requerida, tais como: relatório ambiental, plano e projeto de controle ambiental, relatório ambiental preliminar, diagnóstico ambiental, plano de manejo, plano de recuperação de área degradada e análise preliminar de risco" (grifo nosso).

Portanto, o Relatório Ambiental Preliminar (RAP) é “(...) mais sucinto e

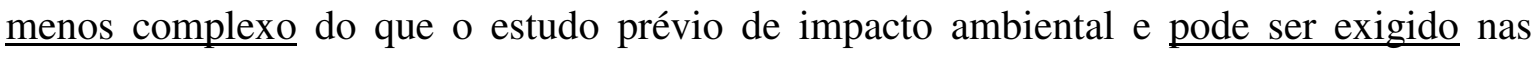
hipóteses em que as atividades ou obras não forem potencialmente causadoras de significativa degradação ambiental" (itálico do original, grifo nosso), no magistério de Luís Paulo Sirvinskas $^{246}$.

Desta forma, no artigo 18, da Lei Geral de Gestão de Florestas Públicas, é determinado que a licença prévia para uso sustentável da unidade de manejo de uma concessão florestal será requerida pelo órgão gestor, mediante a apresentação de Relatório Ambiental Preliminar (RAP) ao órgão ambiental competente integrante do Sistema Nacional do Meio Ambiente - SISNAMA, regra esta que é repetida no artigo 25, do Regulamento da Lei Geral de Gestão de Florestas Públicas.

Considerou-se a atividade de manejo florestal sustentável como de menor potencial ofensivo ao meio ambiente, por isso tendo sido exigido no licenciamento apenas a apresentação de Relatório Ambiental Preliminar (RAP), para obtenção da licença prévia.

Contudo, no $\S 1^{\circ}$, do mesmo dispositivo legal, foi previsto que deverá ser exigido o Estudo Prévio de Impacto Ambiental (EPIA) para obtenção da licença prévia naqueles casos de significativa degradação do meio ambiente, assim considerados, entre outros aspectos, a escala, a intensidade do manejo florestal e a peculiaridade dos recursos ambientais.

Para as diferentes unidades de manejo integrantes de um mesmo lote de concessão florestal, desde que estejam situadas no mesmo ecossistema e no mesmo Estado,

${ }^{246}$ Op. cit., p. $154-155$ 
o órgão ambiental licenciador poderá optar pela realização de Relatório Ambiental Preliminar (RAP) e Estudo Prévio de Impacto Ambiental (EIA), conforme o $2^{\circ}$, do aludido dispositivo legal.

Nos termos do artigo 28, do Regulamento da Lei Geral de Gestão de Florestas Públicas, o Relatório Ambiental Preliminar (RAP) deverá observar um termo de referência, preparado em conjunto pelo IBAMA e pelo Serviço Florestal Brasileiro - SFB, com, no mínimo, o seguinte conteúdo descritivo:

a) das unidades de manejo e sua localização georreferenciada;

b) das características de solo, relevo, tipologia vegetal e classe de cobertura;

c) da flora e da fauna, inclusive com a indicação daquelas ameaçadas de extinção e endêmicas;

d) dos recursos hídricos das unidades de manejo;

e) dos resultados do inventário florestal;

f) da área do entorno;

g) da caracterização das áreas de uso comunitário, unidades de conservação, áreas prioritárias para a conservação, terras indígenas e áreas quilombolas adjacentes às unidades de manejo;

h) da identificação dos potenciais impactos ambientais e sociais e ações para prevenção e mitigação dos impactos negativos;

i) das recomendações de condicionantes para execução de atividades de manejo florestal.

O Relatório Ambiental Preliminar (RAP) ou Estudo Prévio de Impacto Ambiental (EPIA) terão seus custos ressarcidos ao órgão público pelo ganhador da licitação, após contratação da concessão florestal (artigo 18, §3º da Lei Geral de Gestão de Florestas Públicas) e a licença prévia tem por objetivo autorizar a elaboração do Plano de Manejo Florestal Sustentável (PMFS) e, no caso de unidade de manejo inserida no PAOF, a licitação para a concessão florestal ( $§ 4^{\circ}$, do mesmo dispositivo).

Portanto, a licença prévia é obtida pelo órgão gestor das florestas públicas para duas finalidades, a elaboração de Plano de Manejo Florestal Sustentável (PMFS) e viabilizar a inserção de determinada unidade de manejo inserida no PAOF numa licitação para concessão florestal.

Assim sendo, a licença prévia tem caráter preparatório, pois, somente com a licença de operação, obtida pelo concessionário, e a aprovação do respectivo Plano de Manejo Florestal Sustentável (PMFS), pelo órgão competente do SISNAMA, é que 
poderão ser iniciadas as atividades florestais na unidade de manejo, nos termos do artigo $18, \S 5^{\circ}$ da Lei Geral de Gestão de Florestas Públicas.

Interessante notar, que o licenciamento ambiental para uso sustentável da unidade de manejo de concessão florestal não exige a obtenção da licença de instalação, sendo exigidas somente as citadas licenças prévia e de operação, por força do artigo $18, \S$ $6^{\underline{0}}$ da Lei Geral de Gestão de Florestas Públicas.

Na hipótese de criação de Floresta Nacional, Estadual ou Municipal, conforme disciplina o artigo $4^{\circ}$, inciso I, da Lei Geral de Gestão de Florestas Públicas, em que o poder público exercerá a gestão direta de tais florestas públicas, o plano de manejo de tais Unidades de Conservação substitui a licença prévia abordada neste tópico, sem prejuízo da elaboração de estudo de prévio de impacto ambienta (EPIA) exigido em determinadas situações e observância de outros requisitos do licenciamento ambiental, conforme artigo $18, \S 8^{\circ}$ da mesma lei.

Para o licenciamento ambiental do manejo florestal, o concessionário submeterá à análise técnica do Instituto Brasileiro do Meio Ambiente e dos Recursos Naturais Renováveis - IBAMA o Plano de Manejo Florestal Sustentável - PMFS e os empreendimentos industriais incidentes nas unidades de manejo e as obras de infraestrutura não inerentes ao referido plano, deverão observar normas específicas de licenciamento ambiental, nos termos dos artigos 26 e 27, do Regulamento da Lei Geral de Gestão de Florestas Públicas.

O quanto abordado neste tópico pode assim ser resumido:

a) o licenciamento ambiental para uso sustentável da floresta pública é composto por somente duas fases, a da licença prévia e a da licença de operação, uma vez que não se aplica a licença intermediária, de instalação;

b) a licença prévia deve ser obtida pelo órgão gestor, antes da inserção de uma unidade de manejo em licitação para concessão florestal, por meio da apresentação de Relatório Ambiental Preliminar (RAP), para atividades de menor potencial de degradação ambiental, caso contrário deverá se exigido um Estudo Prévio de Impacto Ambiental (EPIA);

c) a licença de operação deve ser obtida pelo concessionário, mediante a apresentação do Plano de Manejo Florestal Sustentável (PMFS);

d) poderão ser exigidos licenciamentos ambientais específicos para outros empreendimentos industriais e obras de infra-estrutura inseridas na unidade de manejo.

De tudo o que se abordou, conclui-se que as licenças ambientais prévia e de operação, específicas no licenciamento ambiental para o uso sustentável de florestas 
públicas pela concessão florestal, possuem natureza jurídica efetiva de licença e não autorização, uma vez que são instrumentos declaratórios do direito subjetivo do empreendedor à citada exploração sustentável da floresta, conforme previsto na lei e disciplinado pelo contrato de concessão florestal.

A rigor, o licenciamento ambiental como providência prévia à licitação é composto apenas pela fase inicial, de obtenção da licença prévia, mediante a apresentação do Relatório Ambiental Preliminar (RAP) ou Estudo Prévio de Impacto Ambiental (EPIA), nos casos previstos na Lei Geral de Gestão de Florestas Públicas, pelo órgão gestor das florestas públicas, pois a fase final, de obtenção da licença de operação, ocorre em momento posterior ao entabulamento do contrato de concessão florestal e fica a cargo do concessionário.

\subsection{Autorização legislativa prévia:}

A correta análise deste tema exige sua divisão em três questões:

a) a primeira: se é exigível ou não a autorização legislativa prévia à alienação de bens públicos;

b) a segunda: sendo exigível para a citada alienação, se o sentido de tal expressão deve ser ampliado para abarcar a hipótese de concessão de uso de bem público ao particular e, portanto, se a autorização legislativa é exigível em concessões florestais, independentemente da área da unidade de manejo;

b) a terceira: se a regra constitucional de autorização legislativa do Congresso Nacional para a concessão de áreas públicas de grande dimensão é ou não aplicável à concessão florestal e qual o âmbito dessa aplicação.

\subsubsection{Autorização legislativa na transferência de propriedade de bens públicos:}

Em relação à primeira questão, Floriano Peixoto de Azevedo Marques Neto $^{247}$ professa que a "exigência de lei prévia para alienação de bens imóveis é de constitucionalidade duvidosa", pois a Constituição Federal teria reservado "a exigência de autorização legislativa apenas à alienação de um tipo específico de bem público (dimensão territorial significativa)", motivo pelo qual uma norma infraconstitucional não poderia ampliar esta exigência", aliado ao fato também de que "a exigência de autorização

${ }^{247}$ Op. cit., p. 359-360 
legislativa para a gestão dos bens públicos, por caracterizar uma exceção ao princípio da separação dos poderes, deve ser aplicada restritivamente".

Em direção oposta, Marçal Justen Filho ${ }^{248}$ entende que a autorização legislativa é condição da alienação do bem público e relata que parte da doutrina defende que tal autorização ser exigida somente para bens afetados.

Entretanto, realçou o doutrinador que seu entendimento é que tal autorização deve ser exigida para qualquer espécie de bem público, seja de uso comum, especial ou dominical, uma vez que o artigo 48, inciso V, da Constituição Federal “(...) não faz diferenciação entre bens afetados ou não afetados. Portanto, a natureza dominical do bem não significa a ausência de necessidade de autorização legislativa para a sua alienação.”, ressaltando, ainda, que em relação aos bens de uso comum e de uso especial a lei de desafetação pode implicitamente autorizar a alienação de tais bens.

Diogenes Gasparini ${ }^{249}$, por seu turno, ao explicar o procedimento para a alienação de bens públicos imóveis, expôs que somente será legítima se observada, entre outros requisitos, a regra da autorização legislativa prévia.

Ele $^{250}$ também expõe que, no âmbito da União, a autorização legislativa não é exigível, pois o artigo 23, da Lei ${ }^{\circ}$ 9.636, de 15 de maio de 1998, declara ser suficiente ato do Presidente da República, sempre precedido de parecer da Secretaria de Patrimônio da União - SPU, quanto à oportunidade e conveniência, podendo tal competência ser delegada ao Ministro de Estado da Fazenda, permitida até a subdelegação.

O doutrinador ${ }^{251}$ assevera que tal regra é aplicável somente à União, pois “A alienação de bens de outras entidades da Federação, a cada caso, há de ser precedida de autorização legislativa, segundo, a exemplo de outras, prescreve a Constituição de São Paulo (art. 19, IV)".

Do relatado, conclui-se que uma linha doutrinária defende que a autorização legislativa representaria uma interferência indevida do Poder Legislativo na gestão de bens públicos, atribuição esta exclusiva do Poder Executivo e que a norma do artigo 17, "caput", da Lei Geral de Licitações e Contratos Administrativos feriria a autonomia dos entes federativos estaduais e municipais.

Em sentido contrário, outra linha doutrinária defende que a autorização legislativa não é exigível no âmbito federal, por causa de lei posterior e específica em

\footnotetext{
${ }^{248}$ Op. cit., p. 219

${ }^{249}$ Direito Administrativo, São Paulo: Saraiva, 2008. p. 917

${ }^{250}$ Loc. cit.

${ }^{251}$ Loc. cit.
} 
sentido contrário, possuindo a regra do citado artigo 17, "caput”, apenas caráter federal, pois regra estadual e municipal poderia determinar sua observância na alienação (entendida restritivamente como transferência de propriedade) de bens públicos.

Do cotejo das duas linhas doutrinárias, entende-se que a autorização legislativa prévia à alienação de bens públicos, prevista no citado dispositivo legal, não configura desrespeito de um poder sobre outro e que é possível tal regra ser afastada por lei posterior apenas no âmbito federal.

A regra do artigo 17, "caput", da Lei Geral de Licitações e Contratos Administrativos, possui caráter geral e se aplica aos Estados, Distrito Federal e Municípios, podendo tais entes também, como fez o Estado de São Paulo, prever em lei local a obrigatoriedade de tal autorização legislativa, reforçando aquele dispositivo legal.

Por se tratar de competência legislativa concorrente, os Estados, Distrito Federal e Municípios não podem legislar de forma diversa (artigos 22, inciso XXVII cumulado com o artigo 24, §4 , da Constituição Federal).

\subsubsection{Autorização legislativa na concessão de uso de bens públicos:}

A segunda questão decorre da defesa, por determinada linha de doutrinadores, de que o artigo 17, "caput", da Lei no 8.666, de 21 de junho de 1993 (Lei Geral de Licitações e Contratos Administrativos), ao disciplinar a "alienação", o fez em sentido amplo, neste termo devendo ser incluídas as hipóteses de outorga do uso do bem público ao particular, ou seja, de apenas um atributo da propriedade.

Com efeito, essa corrente doutrinária alarga o significado do termo “alienação", constante no citado artigo 17, extrapolando-o para outras situações além da transferência de propriedade.

Nesta senda é a doutrina de Marçal Justen Filho ${ }^{252}$ que cerziu o comentário ao dispositivo legal em apreço assim:

$\mathrm{O}$ art. 17 concentra as normas da Lei $\mathrm{n}^{\circ} 8.666$ atinentes à alienação de bens e direitos por parte da Administração Pública. A expressão "alienação" é utilizada numa acepção ampla. Compreende-se tanto a alienação no sentido próprio e técnico como também outros institutos que possibilitam a outro sujeito o uso e a fruição parcial ou temporária de bens e de direitos de titularidade da Administração Pública. (...) Mas o dispositivo trata também de outros institutos que

${ }^{252}$ Comentários à Lei de Licitações e Contratos Administrativos, São Paulo: Dialética, 2008. p. 212 
propiciem a atribuição a terceiros de direitos de uso e fruição sobre bens imóveis. Rigorosamente, essas figuras não se enquadram no conceito de "alienação", mas estão abrangidas nas regras correspondentes eis que envolvem a transferência pela Administração da posse e de faculdades de uso e fruição quanto a bens públicos. Os interesses em jogo são similares e há uma equivalência quanto ao tipo de relacionamento entre a Administração e os particulares. (grifo nosso)

Se adotada tal forma de pensar, esta regra deve ser considerada geral para toda e qualquer concessão de uso de bem público imóvel ao particular, o que foi explicitado pelo mesmo doutrinador ${ }^{253}$ : “Assim, por exemplo, afigura-se claro que o art. 17 alcança as outorgas de concessão de uso e de direitos reais sobre bens públicos." (grifo nosso).

$\mathrm{Na}$ segunda linha de doutrinadores, encontram-se aqueles que defendem a desnecessidade de autorização legislativa prévia à concessão de uso de bem público (e outras hipóteses de outorga do uso), pois adotam interpretação restritiva do termo "alienação" do mencionado artigo 17, da Lei Geral de Licitações e Contratos Administrativos, se comparados aos doutrinadores da primeira linha de pensamento.

É exemplo de doutrinador que pensa desta maneira Floriano Peixoto de Azevedo Marques Neto ${ }^{254}$, que ensina que o termo "alienação" deva ser usado para expressar a “(...) transferência de domínio do bem, por qualquer negócio jurídico admitido (...)" e que ressalta: "Firmamos isso para deixar desde logo apartada a hipótese de alienação do bem público das hipóteses de outorga, aos particulares, de direitos especiais (privativos) de uso." (grifo nosso).

Caminha na mesma trilha Edmir Netto de Araújo ${ }^{255}$, para quem o termo "alienação" deve ser entendido como a definição do artigo 6 ${ }^{\circ}$, inciso IV, da Lei no 8.666/93 e alterações posteriores, tratando-se de "transferência, para outrem, do direito de propriedade (eliminando eventuais dúvidas sobre alienação da posse-concessão, permissão), e abrangendo transferências não onerosas, além das remuneradas: alienação é gênero de "venda", “doação", "permuta", "investidura", "dação em pagamento" etc" (itálico do original, grifo nosso).

Mas, o mesmo doutrinador chama atenção para o fato que, no âmbito do Estado de São Paulo, a autorização legislativa prévia à concessão de uso de bem público é

\footnotetext{
${ }^{253}$ Op. cit., p. 213

${ }^{254}$ Op. cit., p. 358

${ }^{255}$ Curso de Direito Administrativo, São Paulo:Saraiva, 2005. p. 499
} 
obrigatória em razão de dispositivos constitucionais estaduais (artigo 19, incisos IV e V, da Constituição do Estado de São Paulo).

Vale lembrar, ainda, que não é incomum as Leis Orgânicas de Municípios atribuírem ao Poder Legislativo a competência de autorizar, por lei, previamente, a alienação de bens públicos a pessoa jurídica pública ou privada, entendendo-se tal “alienação" na acepção ampla, também de outorga do uso privativo.

Não se pode olvidar que, no âmbito da concessão de serviço público, regra geral semelhante, impositiva da autorização legislativa prévia à realização da concessão é encontradiça no artigo $2^{\circ}$, da Lei $\mathrm{n}^{\circ} 9.074$, de 07 de julho de 1995, que modificou a Lei $\mathrm{n}^{\circ}$ 8.987, de 13 de fevereiro de 1995 (Lei Geral de Concessões e Permissões), sendo ela dispensada somente nos casos expressos da Constituição Federal, Constituições Estaduais, Leis Orgânicas Municipais e no saneamento básico e limpeza urbana.

E mais, também em relação à concessão de serviço público adoção de tal regra não é pacífica, havendo doutrinadores que defendem a sua desnecessidade, tal como Marcos Juruena Vilela Souto ${ }^{256}$, baseado nos seguintes argumentos:

a) que a "delegação do serviço público mediante concessão configura ato de gestão, que, na sistemática constitucional da separação de Poderes, cabe, principiologicamente, ao Poder Executivo";

b) que tal autorização da lei federal feriria o pacto federativo, pois a Lei Geral de Concessões e Permissões de Serviço Público, "não se tratando de norma geral, não poderia (...) descer a minúcias que interfiram na autonomia municipal e estadual”.

Além de tal doutrinador, Maria Sylvia Zanella Di Pietro ${ }^{257}$, conforme demonstrado no tópico 2.3 deste trabalho, também defende a inconstitucionalidade da regra de imposição de autorização legislativa prévia em licitações para concessão de serviço público, com argumentos semelhantes.

Diante dos entendimentos doutrinários expostos, entende-se que o termo “alienação", constante no artigo 17, "caput”, da Lei n 8.666, de 21 de junho de 1993 (Lei Geral de Licitações e Contratos Administrativos) deve ser interpretado de forma restrita, tal como definido no artigo $6^{\circ}$, inciso IV, da mesma Lei.

Desta forma, não sendo aplicável o dispositivo geral aos Estados, Distrito Federal e Municípios, tais entes federativos, poderão estabelecer regra impositiva da

\footnotetext{
${ }^{256}$ Direito Administrativo das Concessões, Rio de Janeiro: Lumen Juris, 2004. p, 48

${ }^{257}$ Parcerias na Administração Pública, Concessão, Permissão, Franquia, Terceirização, Parceria PúblicoPrivada e outras Formas, São Paulo: Atlas, 2006. p. 89 - 90
} 
autorização legislativa prévia em concessão de serviço público e concessão de uso de bem público (inclusive concessão florestal), porém, conforme entendimentos de Maria Sylvia Zanella Di Pietro e Marcos Juruena Vilela Souto, tal regra poderá ser questionada quanto à constitucionalidade, pelo desrespeito ao artigo $2^{\circ}$, da Constituição Federal (cláusula de separação dos poderes), até porque no próprio texto constitucional não foi estabelecida regra específica que permita a interferência de um poder sobre o outro em ato de gestão de transferência de serviço público ou uso de bem público a particular.

\subsubsection{Autorização legislativa do Congresso Nacional:}

A terceira questão refere-se à aplicação do artigo 49, inciso XVII e artigo 188, $\S 1^{\circ}$, ambos da Constituição Federal, na concessão de uso de bem público imóvel cuja área seja superior a 2.500 há (dois mil e quinhentos hectares), inclusive na concessão de uso de florestas.

A polêmica a respeito da observância dessas disposições constitucionais na concessão florestal instalou-se em dois momentos, durante a tramitação do projeto de lei que originou a Lei Geral de Gestão de Florestas Públicas e na licitação para a primeira concessão florestal no país, em três lotes da Floresta Nacional do Jamari, no Estado de Rondônia, procedimento iniciado em 14 de novembro de 2007.

Durante a tramitação do aludido projeto de lei perante o Senado Federal foram introduzidas emendas no seu artigo 10 para fixar a obrigatoriedade de submissão prévia ao Conselho de Defesa Nacional da concessão florestal em áreas situadas na faixa de fronteira, definida no artigo $20, \S 2^{\circ}$, da Constituição Federal e a obrigatoriedade de prévia autorização do Congresso Nacional quando a área objeto da concessão fosse superior a 2.500 há (dois mil e quinhentos hectares), em obediência ao artigo 49, inciso XVII e artigo $188, \S 1^{\circ}$, também da Constituição Federal.

No artigo 10, $\S 3^{\circ}$, da Lei Geral de Gestão de Florestas Públicas, foi mantida a regra referente às terras situadas na faixa de fronteira, com prévia apreciação do Plano Anual de Outorga Florestal - PAOF, pelo Conselho de Defesa Nacional.

Contudo, o artigo $10, \S 4^{\circ}$, da Lei Geral de Gestão de Florestas Públicas foi vetado pelo Chefe do Executivo que, na Mensagem de Veto $\mathrm{n}^{\circ} 124$, de 02 de março de 2006, argumentou que a manutenção de tal regra feriria o princípio insculpido no artigo $2^{\circ}$, inciso VIII, da mesma lei, que garante condições estáveis e seguras para estimular investimentos de longo prazo no manejo, na conservação e recuperação das florestas, além 
de submeter o Plano Anual de Outorga Florestal - PAOF “(...) a contingências políticas de curto prazo, além de criar novos processos administrativos para a tramitação da matéria."

Consigna-se, neste ponto, que a submissão do PAOF à análise e autorização legislativa prévia do Congresso Nacional, conforme objetivava a referida emenda parlamentar inserida no Senado Federal, não era o mais razoável, pois tal plano é atribuição do Poder Executivo, não havendo sentido o Poder Legislativo interferir em seu conteúdo, sob pena de atentado ao princípio da separação de poderes da República, insculpido no artigo $2^{\circ}$, da Constituição Federal.

Em que pese tal entendimento, o fato é que no Supremo Tribunal Federal tramita uma ação direta de inconstitucionalidade (ADI $n^{\circ} 3.989 / \mathrm{DF}$ ), manejada pelo Partido Popular Socialista - PPS, com o objetivo de declarar a inconstitucionalidade parcial do artigo 10, da Lei Geral de Gestão de Florestas Públicas, por ofensa ao citado dispositivo constitucional, ação esta ainda pendente de julgamento.

O segundo momento de polêmica sobre a aplicação dos dispositivos constitucionais que determinam a prévia autorização legislativa do Congresso Nacional para concessão de uso de áreas de grande dimensão, relata Stela Maria Ramos de Melo ${ }^{258}$, ocorreu antes da fase de julgamento das propostas técnicas das licitantes, na licitação da Floresta Nacional do Jamari.

Tal processo de licitação foi interrompido por uma decisão de antecipação de tutela proferida pelo Primeiro Tribunal Regional Federal de Rondônia, fundamentada no argumento que tal processo deveria ter sido antecedido da autorização legislativa do Congresso Nacional, para cumprir o que determina o artigo 49, inciso XVII e o artigo 188, $\S 1^{\circ}$, ambos da Constituição Federal, pois as unidades de manejo possuíam áreas superiores a 2.500 ha (dois mil e quinhentos hectares).

A União encaminhou o caso ao Supremo Tribunal Federal, em ação ${ }^{259}$ na qual o Ministro Presidente Gilmar Mendes revogou os efeitos da decisão que suspendera o processo licitatório argumentando em sua decisão individual que:

(...) não se mostra indispensável a submissão prévia ao Parlamento Nacional para aprovação ou não de tal certame porque não se trata de alienação de domínio. Não se pode confundir concessão florestal com concessão dominial. A concessão florestal não implica em transferência da posse da terra pública, mas sim a delegação onerosa do direito de praticar o manejo florestal sustentável na área e o artigo 10,

${ }^{258}$ Loc. cit.

${ }^{259}$ Suspensão de tutela antecipada STA n ${ }^{\circ} 235$, ainda pendente de julgamento final. 
parágrafo $4^{\circ}$ da Lei $11.284 / 2006$, citado pelo MPF e que exigia, no caso, a autorização do Congresso Nacional, foi vetado pelo presidente Lula." (grifo nosso).

Diante de tal polêmica, duas vertentes foram erigidas, uma favorável e outra contrária à observância do artigo 49, inciso XVII e artigo 188, §1º, da Constituição Federal, nas concessões florestais de áreas superiores a 2.500 ha (dois mil e quinhentos hectares).

Vicente Gomes da Silva ${ }^{260}$ pertence à primeira corrente de entendimento e, defendendo a observância do mandamento constitucional, anotou:

É importante notar que a lei fala de concessão de florestas, não se pode desconhecer que a floresta é bem público, encravada sobre a terra, acessório indissociável da mesma, e por isso, a floresta não existe sem a terra e dela não pode desgarrar-se. (...) Atender ao preceito legal de inspiração constitucional significa maior participação popular sobre o uso e destinação dos bens públicos e efetivo controle social sobre as atividades do governo. (grifo nosso)

Também entende dessa forma Marçal Justen Filho ${ }^{261}$, ressaltando apenas que, para os demais entes federativos, além da União, deverão obter "além da autorização legislativa de competência do próprio ente político (...) uma segunda autorização, de competência do Congresso Nacional.".

Em direção oposta caminha Rafael Véras de Freitas que professa que “(...) a transferência para o particular da exploração de produtos florestais não necessita de prévia autorização do Congresso Nacional, tendo em vista a autonomia dos conceitos de propriedade do solo e da exploração de seus acessórios".

Para reforçar sua tese, argumenta que a Constituição Federal, em diversos dispositivos, divorcia a propriedade do solo da circulação de seus acessórios, como ocorre no seu artigo 176, que dispõe sobre as jazidas, demais recursos minerais e potenciais de energia elétrica, que constituem propriedade distinta da do solo para efeito de exploração ou aproveitamento, e pertencem à União, garantida ao concessionário a propriedade do produto da lavra, o que é confirmado pelo artigo 1.230, do Código Civil.

Entende-se, porém, que tal argumento não merece prosperar, pois se alicerça em dispositivo constitucional que disciplina uma situação específica das jazidas

\footnotetext{
${ }^{260}$ Op. cit., p. 3154
}

${ }^{261}$ Op. cit. p. 220 
minerais e potenciais de energia elétrica, não podendo ser acolhida uma interpretação ampliativa, ou mesmo analógica, que abarque as florestas públicas.

Além disso, não se pode deduzir que a citada regra constitucional criou uma hipótese de livre circulação de acessórios da propriedade pública sem a referida autorização legislativa prévia, pois, se assim desejasse o legislador constitucional teria disposto de forma ampla sobre a matéria.

Nesta trilha, as regras do artigo 49 , inciso XVII e artigo $188, \S 1^{\circ}$, ambos da Constituição Federal são muito evidentes e específicas para uma situação definida: toda e qualquer concessão de terras públicas de grande dimensão, assim entendidas aquelas maiores que dois mil e quinhentos hectares, deverá ser submetida previamente ao crivo do Poder Legislativo federal.

A regra constitucional é específica para essa situação, independentemente da finalidade do repasse destas ao particular e do ente público que sobre elas exerça o domínio.

Por outro lado, entende-se que é uma daquelas exceções ao princípio da separação dos poderes, por isso mesmo explicitada no próprio texto constitucional, o que também conduz à conclusão que não podendo existir uma lei local, estadual ou municipal, por exemplo, que afaste a obrigatoriedade de sua observância.

Se a imposição de prévia autorização legislativa estivesse no bojo da Lei Geral de Gestão de Florestas Públicas e inexistisse dispositivo constitucional específico, ocorreria situação semelhante à relatada no subtópico anterior, relativa às concessões de serviço público, sendo claramente inconstitucional tal dispositivo legal aventado.

Com tal entendimento, o fato é que o Poder Executivo de qualquer ente federativo, por intermédio do órgão gestor das florestas públicas, pode incluir uma área maior do que o limite da regra constitucional num lote de concessão florestal, contudo, na tramitação do processo, antes da abertura do procedimento licitatório, deverá obter a concordância do Congresso Nacional por meio de lei específica.

Tratando-se, por sua vez, de florestas estaduais ou municipais e havendo dispositivo em Constituição Estadual ou Lei Orgânica Municipal que exija autorização legislativa para concessão de uso de terras públicas de qualquer medida, tais entes federativos também deverão providenciar tal autorização das Assembléias Legislativas ou Câmaras de Vereadores, podendo, porém, tais dispositivos serem contestados pelos argumentos expostos no subtópico anterior, referentes à concessão de serviço público. 
Neste diapasão, vislumbra-se desacerto nos fundamentos da decisão liminar do Supremo Tribunal Federal, pois na concessão florestal também se transfere a posse, que se expressa na exploração sustentável da floresta pública.

Deste modo alinhavado, confirma-se a obrigatoriedade de autorização legislativa prévia também nas concessões florestais, em qualquer âmbito federativo, caso a área recoberta pela floresta seja de dimensão superior ao limite constitucional de dois mil e quinhentos hectares.

\subsection{Procedimento da licitação para concessão florestal:}

A licitação, como todo procedimento administrativo, é composta por fases que visam o atingimento de um provimento final.

$\mathrm{Na}$ doutrina consagrou-se posicionamento quanto à existência da fase preliminar (ou fase interna), fase de publicação do edital, fase de habilitação, fase de classificação das propostas, fase de julgamento, fase de homologação e fase de adjudicação, para melhor compreensão da matéria.

Em razão das especificidades da concessão florestal, com amplo regramento próprio na Lei Geral de Gestão de Florestas Públicas, nos tópicos antecedentes foram analisadas as principais medidas que compõem a fase preliminar da licitação para concessão florestal, restando algumas que são analisadas no tópico seguinte, na fase de publicação do edital.

Em caráter preliminar, cabe apontar que no artigo $7^{\circ}$, da citada Lei, consta que a concessão florestal é "autorizada em ato do poder concedente" e "formalizada mediante contrato" e deve observar o referido regramento específico, além do contido no edital de licitação.

A redação do citado dispositivo é imperfeita, pois o legislador faz uso de termo ("autorizar"), referente a outro instrumento de outorga do uso de bem público a particular (a autorização de uso), para designar uma concessão de uso.

Também é imperfeita a menção a um "ato" de outorga da concessão florestal, pois, conforme alhures demonstrado neste trabalho, esta é uma espécie de concessão de uso, portanto, com natureza jurídica contratual, bilateral, e não de mero ato administrativo, unilateral. 
A expressão "formalizada mediante contrato" também induz a interpretação de toda errônea que o termo "contrato" não se refere à relação jurídica, mas somente ao instrumento contratual, mero veículo de seu registro.

Ultrapassados os desencontros iniciais, a Lei Geral de Gestão de Florestas Públicas delineia vários aspectos do procedimento de licitação e do contrato administrativo dele decorrente que merecem investigação tópica para melhor ordenação.

No artigo 13, da Lei Geral de Gestão de Florestas Públicas, há regra que dispõe que a Lei $n^{\circ}$ 8.666, de 21 de junho de 1993 e alterações posteriores deve ser aplicada supletivamente, respeitados os princípios da legalidade, moralidade, publicidade, igualdade, do julgamento por critérios objetivos e da vinculação ao instrumento convocatório, motivo pelo qual, neste trabalho, há o cotejo das normas específicas da Lei Geral de Gestão de Florestas Públicas com aquelas gerais da Lei Geral de Licitações e Contratos Administrativos.

No artigo 69, da Lei Geral de Gestão de Florestas Públicas, é permitida a delegação de atividades relacionadas à concessão florestal, mediante convênio firmado com o órgão gestor competente, pelos Estados, Distrito Federal e Municípios à União, bem como por esta aos demais entes federados, sem prejuízo das competências materiais comuns de proteção do meio ambiente e preservação da flora e fauna, dispostas no artigo 23, incisos VI e VII, da Constituição Federal.

Esta regra, em verdade, não se relaciona especificamente à fase de publicação do edital da licitação, possuindo um caráter geral, pois não houve clara definição de quais seriam as atividades relacionadas à concessão florestal que podem ser objeto de delegação pelos entes públicos entre si.

Assim, em princípio, a própria realização de uma concorrência para concessão florestal incidente sobre áreas sob o domínio de um Município poderia ser delegada à União Federal, sem dúvida melhor aparelhada para a promoção de tal procedimento, até porque possui o Serviço Florestal Brasileiro, órgão administrativo especializado na matéria.

Visualiza-se a possibilidade de um convênio para a delegação de atividades acessórias, porém indispensáveis à licitação para concessão florestal, como a elaboração de documentos técnicos, de Relatório Ambiental Preliminar - RAP, Estudo Prévio de Impacto Ambiental - EPIA entre outros, como também de atividades inerentes a condução do contrato de concessão florestal, tal como a gestão técnica, fiscalização etc. 
Assevera o artigo 69, parágrafo único, da Lei Geral de Gestão de Florestas Públicas, que é vedado ao órgão gestor conveniado exigir do concessionário sob sua ação complementar de regulação, controle e fiscalização obrigação não prevista previamente em contrato.

A inserção de tal regra pelo legislador federal procurou reforçar que a delegação de atribuições de um ente federativo para outro, no âmbito da gestão de concessões florestais, encontra limite, em relação ao concessionário, no conjunto normativo composto pelas cláusulas do contrato de concessão florestal ${ }^{262}$ ao qual aderiu.

Finalmente, ainda no campo das regras gerais, tem-se que a competência para a formulação de estratégias, políticas, planos e programas em matéria de gestão de florestas públicas e, em especial a definição do Plano Anual de Outorga Florestal, oitiva do órgão ambiental consultivo quanto às ações, estabelecimento dos termos de licitação, critérios de seleção, publicação de editais, julgamento de licitações, definição e formalização dos contratos para manejo florestal sustentável e concessões florestais, além do planejamento de ações voltadas à regulação do mercado florestal, quando couber, é do poder concedente, representado, no caso da União, pelo seu Ministério do Meio Ambiente, podendo, porém, as atividades de operacionalização da licitação e celebração dos contratos ser delegadas ao órgão gestor, no caso, o Serviço Florestal Brasileiro - SFB, conforme artigo 49 e seus $\S$, da Lei Geral de Gestão de Florestas Públicas.

Ultrapassadas as regras gerais aplicáveis à licitação e ao contrato de concessão florestal, adentra-se em cada uma das fases teóricas da licitação.

\subsubsection{Fase de publicação do edital:}

A publicação do edital na licitação para concessão florestal, assim como ocorre nas licitações em geral, delimita o momento da efetiva abertura do procedimento.

A Lei Geral de Gestão de Florestas Públicas, em relação a tal fase, delineou algumas especificidades que merecem detida atenção, o que é abordado nos tópicos seguintes, onde são analisadas providências prévias à publicação do edital e os todos os aspectos que devem ser nele disciplinados.

\footnotetext{
${ }^{262}$ Não só na concessão florestal, como também na concessão de direito real de uso de unidade de manejo sustentável para comunidades locais, que pode ser denominado de contrato de manejo florestal sustentável.
} 


\subsubsection{Disponibilização na rede mundial de computadores:}

Prevê o artigo $7^{\circ}$, parágrafo único, da Lei Geral de Gestão de Florestas Públicas, que o Sistema Florestal Brasileiro é obrigado a disponibilizar na rede mundial de computadores o edital e demais documentos que o instruem, tais como relatórios ambientais preliminares, licenças ambientais, relatórios de impacto ambiental, termo contratual etc.

Essa regra também é aplicável a publicidade daqueles documentos produzidos após o perfazimento da concessão florestal, tais como relatórios de fiscalização, relatórios de auditorias e outros documentos relevantes do processo de concessão florestal.

Por óbvio, tal publicidade na rede mundial de computadores é apenas medida suplementar àquelas formas de publicidade estabelecidas no artigo 21 , incisos I a III, da Lei no 8.666, de 21 de junho de 1993 (Lei Geral de Licitações e Contratos Administrativos) e alterações posteriores, tais como publicação do extrato do edital e demais atos da licitação no veículo de imprensa oficial e jornais de grande circulação.

No artigo 32, parágrafo único, do Regulamento da Lei Geral de Gestão de Florestas Públicas, tal regra de disponibilização do edital na rede mundial de computadores foi repetida, agregando-se a obrigação de disponibilização também nos locais públicos na região de abrangência do lote de concessão florestal, definidos no edital.

\subsubsection{Direito a informação e acesso aos documentos da licitação:}

Além da medida de disponibilização dos documentos referentes à licitação na rede mundial de computadores, no artigo 24, "caput", é previsto que estudos, levantamentos, projetos, obras, despesas ou investimentos efetuados na unidade de manejo e vinculados ao processo de licitação para concessão, realizados pelo poder concedente ou com a sua autorização, devem ser colocados à disposição dos interessados.

No artigo 25, da mesma Lei, foi conferido direito a qualquer pessoa de acesso aos contratos, decisões ou pareceres relativos à licitação ou à concessão florestal.

Tais dispositivos, na verdade, praticamente reproduzem o conteúdo do artigo 63, da Lei Geral de Licitações e Contratos Administrativos, que confere a qualquer interessado o direito de obtenção de cópia autenticada dos termos do contrato e do 
respectivo processo licitatório, mediante o pagamento dos emolumentos devidos, o que também é notado por Toshio Mukai ${ }^{263}$.

A inserção de uma regra específica na Lei Geral de Gestão de Florestas Públicas só contribui para reafirmar o direito de qualquer cidadão, cuja fonte é encontrada nos direitos fundamentais do cidadão, de petição e certidão, previstos no artigo $5^{\circ}$, inciso XXXIV, alienas a) e b), da Constituição Federal, e no princípio da publicidade, que delimita a atuação da Administração Pública, previsto no artigo 37. "caput", da Constituição Federal.

\subsubsection{Audiência pública obrigatória:}

Na licitação para concessão florestal também foi prevista a realização de audiência pública, de caráter obrigatório, antes da publicação do instrumento convocatório, a ser realizada por região, sem prejuízo de outras formas de consulta pública (artigo $8^{\circ}$, da Lei Geral de Gestão de Florestas Públicas).

No artigo 20, $\S 2^{\circ}$, da Lei Geral de Gestão de Florestas Públicas, que trata do edital, prevê expressamente que ele deve ser submetido a audiência pública "previamente ao seu lançamento", reportando-se ao referido dispositivo legal.

Ao esmiuçar tal obrigação legal, o Regulamento da Lei Geral de Gestão de Florestas Públicas, em seu artigo 30, prevê que a audiência pública deverá ser amplamente divulgada, convocada com antecedência mínima de quinze dias da data de publicação do edital e ser conduzida pelo Serviço Florestal Brasileiro - SFB, órgão gestor das florestas públicas.

Para que a audiência pública seja efetiva, impõem os $\S \S 1^{\circ}$ e $2^{\circ}$, do citado dispositivo, que deve ser realizada no local de abrangência do respectivo lote, em datas e locais divulgados nos meios de comunicação de maior acesso ao público da região, além da rede mundial de computadores, e buscar os seguintes objetivos básicos:

a) identificar e debater o objeto da concessão florestal e as exclusões;

b) identificar e debater os aspectos relevantes do edital de concessão, em especial, a distribuição e forma das unidades de manejo e os critérios e indicadores para seleção da melhor oferta;

\footnotetext{
${ }^{263}$ Licitações nas Concessões Florestais, in Revista JML de Licitações e Contratos, Ano I, nº 02, mar. 2007, p. $18-21$
} 
c) propiciar aos diversos atores interessados a possibilidade de oferecerem comentários e sugestões sobre a matéria em discussão; e

d) dar publicidade e transparência às suas ações.

Também, os documentos utilizados para subsidiar a discussão da matéria na audiência pública deverão ser disponibilizados para consulta na rede mundial de computadores e enviados para as prefeituras e câmaras de vereadores dos Municípios abrangidos pelo edital.

Segundo Stela Maria Ramos de Melo $^{264}$, a fixação de obrigatoriedade de audiência pública cumpre princípios exarados na Declaração de Consenso Global sobre gestão de florestas, realizada na Conferência das Nações Unidas, no Rio de Janeiro, em 14 de agosto de 1992, particularmente o quinto princípio que estabelece o reconhecimento e apoio à participação de comunidades e indígenas existentes na área envolvida na referida gestão.

A promoção de audiência pública em licitação não é uma novidade, pois no artigo 39, da Lei Geral de Licitações e Contratos Administrativos, é prevista sua realização obrigatória quando o valor estimado para uma licitação ou para um conjunto de licitações simultâneas ou sucessivas for superior a 100 (cem) vezes o limite previsto no artigo 23, inciso I, alínea c), da mesma lei ${ }^{265}$.

São simultâneas as licitações com objetos similares e com realização prevista para intervalos não superiores a trinta dias e sucessivas aquelas em que, também com objetos similares, o edital subseqüente tenha uma data anterior a cento e vinte dias após o término do contrato resultante da licitação antecedente

Tal audiência pública da Lei Geral de Licitações e Contratos Administrativos deve ser realizada com antecedência mínima de 15 (quinze) dias úteis da data prevista para a publicação do edital e divulgada com a antecedência mínima de 10 (dez) dias úteis de sua realização, pelos mesmos meios previstos para a publicidade da licitação.

Nas duas situações previstas na lei específica e na lei geral o objetivo comum da realização da audiência é proporcionar a transparência dos atos da Administração Pública, contudo, em relação à matéria específica da gestão das florestas públicas, soma-se a tal objetivo geral o corolário do dever de participação da coletividade

\footnotetext{
${ }^{264}$ Loc. cit.

${ }^{265}$ O limite previsto no artigo 23, inciso I, alínea c), da Lei $\mathrm{n}^{\circ}$ 8.666/93 e alterações posteriores é de $\mathrm{R} \$$ 1.500.000 (hum milhão e quinhentos mil reais).
} 
na defesa e preservação do meio ambiente, para as atuais e futuras gerações, previsto no artigo 225, "caput", da Constituição Federal e só se torna efetivo se garantida a aplicação do princípio da informação analisado no subtópico anterior.

Com fundamento em tal princípio é que também pode ser promovida audiência pública em procedimento de licenciamento ambiental, após a apresentação do Relatório de Impacto Ambiental - RIMA, audiência pública esta disciplinada pelas Resoluções CONAMA n $n^{\circ}$ 01, de 23 de janeiro de 1986 e $n^{\circ}$ 09, de 03 de dezembro de 1987, uma vez que não há disposição sobre ela na Resolução CONAMA nº 237, de 19 de dezembro de 1997, que dispõe sobre o procedimento de licenciamento ambiental.

Tal audiência pública em licenciamento ambiental, entretanto, ao contrário da abordada neste subtópico, é de caráter facultativo, conforme artigo $2^{\circ}$, da Resolução CONAMA nº 09, de 03 de dezembro de 1987.

Desta forma, caso seja necessário a elaboração de Estudo Prévio de Impacto Ambiental - EPIA, para a condução da concessão florestal, poderá ocorrer audiência pública após a apresentação do Relatório de Impacto Ambiental - RIMA, com fundamento nas citadas normas e antes da publicação do edital para a citada concessão florestal, no artigo $8^{\circ}$, da Lei Geral de Gestão de Florestas Públicas.

Caso não seja realizada a audiência pública do artigo $8^{\circ}$, da Lei Geral de Gestão de Florestas Públicas, cabível a declaração de nulidade do contrato de concessão florestal, com fundamento no artigo 49, $\S 2^{\circ}$, da Lei Geral de Licitações e Contratos Administrativos, com a aplicação das conseqüências previstas no artigo 59, da mesma lei, devendo o concessionário ser indenizado pelo que houver executado do contrato e por danos que comprovar, contanto que não lhe sejam imputáveis.

Essas regras, entretanto, devem ser aplicadas com a devida razoabilidade, uma vez que, se comprovada que a concessão florestal tenha sido a melhor possível e não se podendo apontar qualquer prejuízo à economicidade, a declaração de nulidade do contrato poderá acarretar maior prejuízo à coletividade e à Administração Pública, motivo pelo qual deve subsistir a contratação da concessão florestal mesmo ausente a referida audiência pública e desde que também não comprovada má-fé.

Além disso, não se vislumbra a audiência pública prévia um meio direto de resguardo do princípio da isonomia e da seleção da proposta mais vantajosa, para alguns denominado princípio da "vantajosidade", previstos no artigo $3^{\circ}$, da Lei Geral de Licitações e Contratos Administrativos, motivo pelo qual a não realização de tal audiência pública poderá ser relevada, observadas as cautelas supra mencionadas. 
Contudo, vale anotar o comentário de Maria Sylvia Zanella Di Pietro ${ }^{266}$ que, ao analisar matéria semelhante constante no artigo 10, inciso VI, da Lei $\mathrm{n}^{\mathrm{o}}$ 11.079, de 30 de dezembro de 2004 (Lei Geral das Parcerias Público-Privadas), de submissão de edital à consulta pública em tais subespécies de concessão de serviço público, de todo aplicável também à concessão florestal:

Não há dúvida de que a exigência é útil em termos de participação dos interessados. Mas ela será inútil para o cumprimento dos princípios da democracia participativa se as sugestões não forem efetivamente examinadas e a sua recusa devidamente justificada. A consulta não poder transformar-se em mero instrumento formal para dar aparência de legalidade à exigência, como costuma acontecer com relação a medidas semelhantes previstas em outras leis.

Concorda-se com a opinião da doutrinadora, que possui maior pertinência em relação à concessão florestal, na medida em que as questões ambientais, conforme demonstrado, exigem discussão principalmente das populações diretamente atingidas por um empreendimento.

Aponta-se, finalmente, que se vislumbra de difícil ocorrência prática a não realização de tal audiência pública, dada e existência dos demais instrumentos de informação e publicidade do edital previstos na Lei Geral de Gestão de Florestas Públicas que acabam por amarrá-la ao procedimento licitatório como um todo.

\subsubsection{Manifestação técnica de conveniência da concessão florestal:}

Além da obrigação de disponibilização dos documentos da licitação (e posterior contratação) na rede mundial de computadores, respeito ao direito de qualquer interessado à informação sobre o procedimento, a realização de audiência pública e a inclusão somente de áreas insertas no PAOF na licitação para concessão florestal, no artigo 12, da L Lei Geral de Gestão de Florestas Públicas, se impõe ao poder concedente a publicação, previamente a do edital de licitação, de um ato administrativo justificando a conveniência da concessão florestal, caracterizando seu objeto e a unidade de manejo.

Trata-se tal ato de justificativa de caráter técnico, assim sendo referido pelo artigo 31, do Regulamento da Lei Geral de Gestão de Florestas Públicas, que também

${ }^{266}$ Direito Administrativo, São Paulo: Atlas, 2008. p. 302 
atribui ao Serviço Florestal Brasileiro - SFB a competência de sua elaboração, cabendo a publicação ser conduzida pelo Ministério do Meio Ambiente.

Nota-se que, tanto na lei, quanto em seu regulamento, não houve uma definição precisa quanto à espécie, conteúdo e forma de tal ato administrativo.

Assim, por se tratar de um ato unilateral e discricionário, por meio do qual a Administração Pública exerce um controle "a priori” dos atos administrativos que compõem o procedimento de licitação, entrevê-se, quanto ao conteúdo, tratar-se de uma aprovação.

Quanto à forma, por configurar ato geral emanado de autoridade diversa do Chefe do Poder Executivo, pode-se concluir que uma resolução ou portaria seriam suficientes para veicular tal manifestação técnica de conveniência da licitação para concessão florestal de determinada unidade de manejo.

Mais uma vez, merece reflexão a hipótese de ausência de tal manifestação técnica de conveniência em determinado procedimento de licitação para concessão florestal, se acarretaria ou não a nulidade de tal concessão, com todas as conseqüências que a Lei Geral de Licitações e Contratos Administrativos determinam, tais como indenização ao concessionário, apuração de responsabilidade etc.

Preliminarmente, deve-se notar que da redação dos dispositivos legais supra comentados não se infere propriamente um dever ao órgão gestor e poder concedente de exarar tal manifestação técnica sob pena de nulidade do procedimento, o que, por sua vez, confirma que, quanto ao conteúdo, tal ato administrativo é uma aprovação.

Noutro sentido, mesmo que seja considerada obrigatória a inserção de tal manifestação no procedimento, sua ausência não acarreta a nulidade do mesmo se demonstrada a economicidade na contratação e o respeito ao princípio da isonomia, atendendo-se o disposto no artigo $3^{\circ}$, da Lei Geral de Licitações e Contratos Administrativos.

Merece anotação também o fato desse ato ser muito semelhante à manifestação de interesse público prevista no artigo 17, “caput", da Lei no 8.666, de 21 de junho de 1993 (Lei Geral de Licitações e Contratos Administrativos), que disciplina a hipótese de alienação de bens públicos, cuja função, no entender de Marçal Justen Filho ${ }^{267}$ é de "evidenciar o cabimento da alienação em face da legislação própria e o cumprimento

${ }^{267}$ Comentários à Lei de Licitações e Contratos, São Paulo: Dialética, 2008. p. 218 
de eventuais requisitos exigidos para tanto. Ademais disso, deverá determinar os atos subseqüentes, necessários à formalização propriamente dita da alienação.”.

Guardadas as devidas proporções, é o que também ocorre na licitação para concessão florestal, pois a manifestação prévia à licitação explicita o fato de uma determinada floresta pública sujeitar-se ao regime jurídico apropriado e sinaliza as medidas posteriores à outorga de seu uso sustentável.

\subsubsection{Florestas públicas elegíveis à concessão florestal:}

As florestas públicas elegíveis à concessão florestal é tema que foi analisado no tópico 5.2.2 retro, podendo-se relembrar que são somente apenas aquelas constantes em unidades de manejo previstas no Plano Anual de Outorga Florestal e no Cadastro-Geral de Florestas Públicas da União e em outros dos Estados, Distrito Federal e Municípios, nos termos do artigo $9^{\circ}$, da Lei Geral de Gestão de Florestas Públicas e artigo 29, inciso I, do Regulamento da Lei Geral de Gestão de Florestas Públicas.

Para constar no Cadastro-Geral de Florestas Públicas da União, em relação às unidades de manejo localizadas dentro dos limites de uma Floresta Nacional, basta o estágio de identificação e nas localizadas fora dos citados limites exige-se o estágio de delimitação, podendo ser contíguas e, neste último caso, se também constituintes de um mesmo PAOF, devem obrigatoriamente compor um mesmo lote de concessão florestal [artigo 29, inciso II, alienas a) e b), $\S \S 1^{\circ}$ e $2^{\circ}$, do Regulamento da Lei Geral de Gestão de Florestas Públicas.

O objeto da exploração, conforme também explicado no tópico 5.1, no início deste capítulo, são os produtos e serviços florestais, especificados no contrato, existentes na unidade de manejo, com perímetro georreferenciado e incluída no lote de concessão florestal (artigo 14, "caput”, da Lei Geral de Gestão de Florestas Públicas).

No edital da licitação deverão também ser definidos claramente quais os produtos e serviços florestais cuja exploração será outorgada, conforme artigo 15, da Lei Geral de Gestão de Florestas Públicas.

Já, os produtos de uso tradicional e de subsistência para as comunidades locais também devem ser explicitados no edital, juntamente com a definição das restrições e da responsabilidade pelo manejo das espécies das quais derivam esses produtos, bem como por eventuais prejuízos ao meio ambiente e ao poder concedente, não podendo ser objeto de concessão florestal (artigo 17, da Lei Geral de Gestão de Florestas Públicas). 
Denota-se dessas regras que os instrumentos prévios de classificação e delimitação das unidades de manejo para concessão florestal são indispensáveis para a promoção do procedimento de licitação, o que também demonstra a existência de uma efetiva política pública de gestão das florestas públicas.

\subsubsection{Modalidade de licitação e impossibilidade de declaração de inexigibilidade:}

No artigo $13, \S \S 2^{\circ}$ e $3^{\circ}$, da Lei Geral de Gestão de Florestas Públicas, são encontradas duas regras que, apesar da aparente singeleza, conferem à concessão florestal importantes especificidades que a diferenciam de outras contratações públicas semelhantes, disciplinadas pelo regramento geral.

Primeiramente, é fixado no citado artigo $13, \S 1^{\circ}$, que as licitações para concessão florestal devem ser realizadas na modalidade concorrência e outorgadas a título oneroso.

Esta regra faz não existir qualquer dúvida quanto à impossibilidade de adoção de outra modalidade de licitação para a concessão florestal, pois, para a concessão de uso comum a Lei Geral de Licitações e Contratos Administrativos não prevê uma modalidade licitatória específica, o que é confirmado por Maria Sylvia Zanella Di Pietro $^{268}$ : "No entanto, a lei se omite quanto à modalidade de licitação cabível na concessão de uso".

Em razão da inexistência de previsão de uma modalidade específica, a doutrinadora $^{269}$ defende que “(...) a disciplina da matéria ficou automaticamente relegada para Estados e Municípios, dentro da sua competência supletiva para legislar sobre licitação e contrato" e "No silêncio das leis estaduais e municipais, a autoridade administrativa poderá optar livremente pela modalidade que lhe parecer mais adequada, já que sua discricionariedade não está limitada por qualquer norma legal.”.

Também defende que não se deve aplicar o critério de valor, previsto no artigo 23, da Lei Geral de Licitações e Contratos Administrativos, uma vez que tal regra é aplicável somente aos contratos de obras, serviços e compras.

Ademais, tal solução de interpretação não necessita ser aplicada às licitações para concessão florestal, diante do dispositivo legal que elegeu a concorrência como única modalidade cabível.

\footnotetext{
${ }^{268}$ Temas polêmicos sobre Licitações e Contratos, São Paulo: Malheiros Editores, 2000. p. 51

${ }^{269}$ Op. cit., p. 52
} 
A segunda regra, prevista no artigo $13, \S 2^{\circ}$, da Lei Geral de Gestão de Florestas Públicas, é aquela que veda a declaração de inexigibilidade prevista no artigo 25, da Lei Geral de Licitações e Contratos Administrativos.

No citado dispositivo da lei geral de licitações, são disciplinadas três situações em que a competição é inviável, em que há “impossibilidade de licitar", na feliz expressão de Maria Sylvia Zanella Di Pietro ${ }^{270}$, sendo elas meramente exemplificativas, pois “(...) outras, não textualmente indicadas, poderão ocorrer no mundo fático quando comprovadamente se estiver diante da inviabilidade de competição”.

Em que pese o esforço do legislador em esmiuçar todos os aspectos relevantes da concessão florestal, não se vislumbra a possibilidade de ocorrerem hipóteses de inexigibilidade passíveis de justificar a não realização de licitação para a concessão florestal, pois, reitera-se, trata-se de uma espécie de concessão de uso e não de aquisição de produtos ou serviços, hipóteses estas disciplinadas pelo artigo 25, da Lei Geral de Licitações e Contratos Administrativos. Portanto, entende-se que a explicitação da inexistência de tal inexigibilidade de licitação na concessão florestal objetivou apenas reforçar o fato.

Não se pode olvidar também que, no artigo $23, \S 1^{\circ}$, da Lei $n^{\circ} 9.427$, de 26 de dezembro de 1996, que dispõe sobre as concessões de serviço público de energia elétrica, foi inaugurada a disciplina desse assunto com disposição genérica semelhante, proibitiva da declaração de inexigibilidade "nas licitações destinadas a contratar concessões e permissões de serviço público e uso de bem público" e, no $\S 2^{\circ}$, do mesmo artigo, é previu que, em tais licitações, “a declaração de dispensa de licitação só será admitida quando não acudirem interessados à primeira licitação e esta, justificadamente, não puder ser repetida sem prejuízo para a Administração, mantidas, neste caso, todas as condições estabelecidas no edital, ainda que modifiquem condições vigentes de concessão, permissão ou uso de bem público cujos contratos estejam por expirar".

Portanto, se esses dispositivos legais forem considerados de caráter geral, a Lei Geral de Gestão de Florestas Públicas não inovou na matéria e o citado dispositivo relativo às hipóteses de dispensa de licitação também se aplica à concessão florestal.

Em relação às hipóteses de dispensa de licitação, tal como dispõe a lei da concessão de energia elétrica, aquela caracterizada pela licitação deserta, ou seja, em que não comparecem interessados, é, sem dúvida, a que merece reconhecimento.

${ }^{270}$ Op. cit., p. 98 
Independentemente da aplicação de tal dispositivo da lei específica das concessões de energia elétrica, a disciplina subsidiária da Lei no 8.666, de 21 de junho de 1993 nas concessões florestais autoriza o reconhecimento da ocorrência das hipóteses de dispensa de licitação de seu artigo 24, em especial a situação de licitação deserta, desde que sejam situações compatíveis e devidamente justificadas.

\subsubsection{Prazo de publicação do aviso do edital:}

Na Lei Geral de Gestão de Florestas Públicas não foi estabelecido um prazo para publicação do aviso de edital, podendo-se adotar aquele previsto no artigo 21 , $\S 2^{\circ}$, inciso I, alínea b), da Lei Geral de Licitações e Contratos Administrativos, com redação dada pela Lei $n^{\circ} 8.883$, de 08 de junho de 1994, de quarenta e cinco dias até o recebimento das propostas ou realização do evento.

A rigor, tal prazo de quarenta e cinco dias é aplicável somente à concorrência cujo contrato a ser celebrado contemple regime de empreitada integral ou se a licitação for de melhor técnica ou técnica e preço, sendo que, fora desses casos, o prazo é de trinta dias, conforme artigo $21, \S 2^{\circ}$, inciso II, alínea a), da Lei Geral de Licitações e Contratos Administrativos.

Contudo, deve-se notar que a razão da lei ter estabelecido prazo mais dilatado para determinadas concorrências deveu-se ao fato da maior complexidade destas, podendo, portanto, à concorrência para concessão florestal ser aplicado prazo igualmente maior, uma vez que o critério de julgamento das propostas nela apresentadas é uma combinação do maior preço com a melhor técnica, na forma do artigo 26, da Lei Geral de Gestão de Florestas Públicas, comprovando tratar-se de concorrência de maior complexidade também.

Se na Lei Geral de Gestão de Florestas Públicas houve silêncio quanto ao prazo, no artigo 32, do seu Regulamento, foi previsto que o edital de licitação para concessão florestal, no âmbito federal, deve ser publicado com antecedência mínima de quarenta e cinco dias da abertura do processo de julgamento das propostas.

Denota-se que a redação de tal dispositivo não é muito técnica, pois melhor teria sido a definição do termo final como data de recebimento das propostas, momento este que demarca a terceira fase do procedimento de licitação, a fase de habilitação. 
Noutro aspecto, houve acerto no dispositivo do decreto regulamentar, uma vez que a competência do Chefe do Poder Executivo federal é adstrita a disciplina do prazo de publicação do edital de concorrência para concessão de florestas sob domínio da União, não podendo estender-se sobre as concessões florestais de competência dos Estados, Distrito Federal e Municípios.

Aos Estados, Distrito Federal e Município, aplica-se o entendimento expendido anteriormente, ou seja, que nas concorrências para concessão florestal conduzidas por tais entes federativos deve-se adotar a regra genérica do artigo $21, \S 2^{\circ}$, inciso I, alínea b), da Lei Geral de Licitações e Contratos Administrativos, não havendo, por outro lado, impedimento do ente federativo manejar sua competência legislativa suplementar para disciplinar tal assunto fixando um prazo específico para tal fim.

A fixação de prazo razoável de, no mínimo, quarenta e cinco dias tal como adotado no decreto regulamentar federal, por parte dos Estados, Distrito Federal e Municípios se impõe, uma vez que seria incongruente a fixação de prazo menor do que o adotado para as outras modalidades de licitação, conforme a lei geral.

\subsubsection{Local de realização dos atos da licitação:}

Quanto ao local de realização da licitação para concessão florestal, a Lei Geral de Gestão de Florestas Públicas não o previu, devendo, neste particular, ser aplicada a regra do artigo 20, da Lei Geral de Licitações e Contratos Administrativos, que dispõe que as licitações serão efetuadas no local onde se situar a repartição interessada, salvo por motivo de interesse público, devidamente justificado.

De forma similar a disciplina do prazo de publicação do edital, somente no artigo 33, do Regulamento da Lei Geral de Gestão de Florestas Públicas, foi que se previu que todos os atos inerentes ao processo de licitação serão realizados na sede do Serviço Florestal Brasileiro - SFB ou no âmbito de suas unidades regionais, conforme justificativa técnica, exceto as audiências públicas e outros atos, previstos em resolução do mesmo órgão.

Relembra-se que, quanto às audiências públicas, comentadas no subtópico 5.4.1.3, devem ser realizadas por regiões (artigo $8^{\circ}$, da Lei Geral de Gestão de Florestas Públicas) e no local de abrangência do respectivo lote (artigo 30, $\$ 1^{\circ}$, do seu Regulamento). 
Portanto, a disciplina do assunto na norma regulamentar é ampliativa, em relação ao dispositivo da lei geral de licitações.

\subsubsection{Requisitos mínimos do edital:}

O artigo 20, da Lei Geral de Gestão de Florestas Públicas, disciplina os requisitos mínimos e específicos do edital da concorrência para concessão florestal, expressamente reafirmando a aplicabilidade das normas e critérios gerais constantes, principalmente, no artigo 40, da Lei Geral de Licitações e Contratos Administrativos.

A rigor, tais disposições aplicáveis particularmente à concessão florestal nem precisariam ser explicitadas na Lei Geral de Gestão de Florestas Públicas, uma vez que o próprio artigo 40, inciso XVII, da Lei Geral de Licitações e Contratos Administrativos, permite que no edital sejam inseridas as "indicações específicas ou peculiares da licitação", portanto, abarcando situações específicas.

Também, em muitos dos incisos de tal dispositivo da Lei Geral de Gestão de Florestas Públicas houve, em síntese, uma repetição das disposições da Lei Geral de Licitações e Contratos Administrativos.

No entanto, no estabelecimento dos requisitos mínimos do edital da concorrência para concessão florestal, houve preocupação em se caracterizar o objeto perante a série de documentos técnicos específicos.

São requisitos mínimos que devem constar no corpo do edital de concorrência para concessão florestal:

a) o objeto com a descrição dos produtos e dos serviços a serem explorados;

b) a delimitação da unidade de manejo, com localização, topografia, mapas, imagens de satélite e informações públicas disponíveis sobre ela;

c) os resultados do inventário amostral;

d) o prazo da concessão e as condições de prorrogação;

e) a descrição da infra-estrutura disponível;

f) as condições e datas para a realização de visitas de reconhecimento das unidades de manejo e levantamento de dados adicionais;

g) a descrição das condições necessárias à exploração sustentável dos produtos e serviços florestais;

h) os prazos para recebimento das propostas, julgamento da licitação e assinatura do termo contratual; 
i) o período, com data de abertura e encerramento, o local e o horário em que serão fornecidos aos interessados os dados, estudos e projetos necessários à elaboração dos orçamentos e apresentação das propostas;

j) os critérios e a relação dos documentos exigidos para a aferição da capacidade técnica, da idoneidade financeira e da regularidade jurídica e fiscal;

k) os critérios, os indicadores, as fórmulas e parâmetros a serem utilizados no julgamento da proposta;

1) o preço mínimo da concessão e os critérios de reajuste e revisão;

m) a descrição das garantias financeiras e dos seguros exigidos;

n) as características dos bens reversíveis, incluindo as condições em que se encontram aqueles já existentes;

o) as condições de liderança da empresa ou pessoa jurídica responsável, na hipótese em que for permitida a participação de consórcio;

p) a minuta do respectivo termo de contrato, que conterá as cláusulas essenciais referidas no artigo 30 da Lei Geral de Gestão de Florestas Públicas;

q) as condições de extinção do contrato de concessão.

Quanto à delimitação da unidade de manejo (localização, topografia, mapas, imagens de satélite e informações públicas) e os resultados do inventário amostral, deverão corresponder à escala da unidade de manejo florestal, caso não se justifique a exigência do detalhamento (artigo 20, $\S 1^{\circ}$, da Lei Geral de Gestão de Florestas Públicas).

Para dar efetividade a tal norma, que possibilita tratamento diferenciado às unidades de manejo pequenas ou médias, pelo artigo 38, do Regulamento da Lei Geral de Gestão de Florestas Públicas, permite-se a utilização dos resultados de inventários florestais de áreas adjacentes ou com características florestais semelhantes.

O inventário amostral, citado na referida norma, é uma espécie de levantamento realizado sobre uma pequena porção da floresta que a ser explorada, normalmente no porcentual de 1 a 2,5\% (um a dois e meio por cento), com a finalidade de verificar o potencial madeireiro, as características físicas (topografia, hidrografia, por exemplo) e projetar as estradas da área de manejo florestal sustentável.

Trata-se de espécie de inventário preliminar, que Eder Zanetti ${ }^{271}$ assim explica:

${ }^{271}$ Certificação e Manejo de Florestas Nativas Brasileiras, Curitiba: Juruá, 2007. p. 137 
Para levantar as capacidades produtivas dos diferentes tipos florestais, os inventários preliminares são utilizados, fornecendo uma visão geral do potencial, principalmente madeireiro, mas também não-madeireiro, das áreas objetivo do programa de manejo sustentado.

O inventário florestal preliminar cumpre com algumas determinações básicas para justificar sua realização, são elas:

a) Identificação das áreas produtivas e estimativas do estoque corrente de madeira em cada área;

b) Permitir estimativas da produtividade sustentada de madeira por unidade de área usando dados levantados com informações preexistentes, com ferramentas de software disponíveis;

c) Fornecer informações que subsidiem a escolha de áreas para conservação;

d) Levantar as possibilidades de mercado para PFNM através da coleta de dados de espécies selecionadas. (grifo nosso)

Não se deve olvidar que a responsabilidade pela demarcação da unidade de manejo é outro requisito que deve ser disposto no edital, devendo ser aprovada pelo Serviço Florestal Brasileiro quando competir ao concessionário, nos termos do artigo $42 \mathrm{e}$ seu parágrafo único, do Regulamento da Lei Geral de Gestão de Florestas Públicas.

A responsabilidade de demarcação da unidade de manejo, portanto, apesar de não ter sido disciplinada num dos incisos do artigo 20, figurando em dispositivo diverso, deverá ser incluída entre as disposições do edital de concorrência para concessão florestal.

Um detalhamento mínimo sobre a definição dos bens reversíveis no edital foi também relegada ao artigo 43, do Regulamento da Lei Geral de Gestão de Florestas Públicas, que dispõe que em tais bens deverão ser incluídos, pelo menos, a demarcação da unidade de manejo, a infra-estrutura de acesso, as cercas, aceiros, porteiras, construções e instalações permanentes.

Neste particular a Lei Geral de Gestão das Florestas Públicas tangencia a Lei $n^{\circ}$ 8.987, de 13 de fevereiro de 1995 (Lei Geral de Concessões e Permissões de Serviço Público), que também determina em seu artigo 18, incisos X e XI, que o poder concedente indique no edital os bens reversíveis, suas características, condições em que serão postos à disposição, nos casos em que houver sido extinta a concessão anterior.

Além disso, por força do artigo 23, inciso X, da Lei Geral de Concessões e Permissões de Serviço Público, os bens reversíveis devem figurar entre as cláusulas 
essenciais do termo contratual, da mesma forma que disciplina o artigo 30, inciso XVI, da Lei Geral de Gestão de Florestas Públicas.

Comparando-se os dispositivos das duas leis, verifica-se que se manteve praticamente uma mesma disciplina jurídica dos bens reversíveis, ou seja, a Lei Geral de Gestão de Florestas Públicas seguiu sistemática similar àquela adotada (Lei Geral de Concessões e Permissões de Serviço Público.

Porém, o fundamento para a reversão dos bens ao poder concedente, uma vez extinta uma concessão de serviço público é o princípio da continuidade do serviço público, o que Maria Sylvia Zanella Di Pietro ${ }^{272}$ assim justifica:

Encerrada a concessão ou a permissão, aqueles bens necessários à prestação do serviço, em regra, só interessam a quem vai dar continuidade à prestação do serviço. Imaginem-se os maquinários, instalações, equipamentos, utilizados nos serviços de energia elétrica, telecomunicações, navegação aérea etc. Extinto o contrato por qualquer das modalidades previstas no art. 35 da Lei $\mathrm{n}^{\circ}$ 8.987, pode, portanto, ocorrer a reversão.

A função da reversão, portanto, é manter a o serviço público em qualquer das hipóteses em que o contrato de concessão for rompido, até mesmo pelo decurso de seu prazo.

Diante de tal finalidade, há de se perquirir a razão dos bens reversíveis em um contrato de concessão florestal, dada sua natureza de concessão de uso de bem público e não de concessão de serviço público.

Dizendo doutra forma, não se vislumbra um serviço público na atividade de manejo florestal sustentável que exija sua não interrupção, caso o contrato seja rescindido, por exemplo.

Sem dúvida, o fundamento para a previsão na Lei de Geral de Gestão de Florestas Públicas da definição, no edital e contrato, de bens reversíveis não se embasa no mesmo fundamento da definição de bens reversíveis na concessão de serviço público, ou seja, não se pode dizer que é o princípio da continuidade do serviço público que justifica a instituição de bens reversíveis na concessão florestal.

O fundamento para a instituição de bens reversíveis na concessão florestal parece ser o próprio princípio do desenvolvimento sustentável, além de certa nota do princípio da precaução, ambos pousados no artigo 225, “caput”, da Constituição Federal.

${ }^{272}$ Parcerias na Administração Pública, Concessão, Permissão, Franquia, Terceirização, Parceria PúblicoPrivada e outras formas, São Paulo: Atlas, 2006. p. 107 
O princípio do desenvolvimento sustentável justifica a instituição dos bens reversíveis na concessão florestal para que a atividade de manejo florestal sustentável não venha a sofrer interrupção, com eventual rompimento da relação jurídica, o que poderia acarretar prejuízo ambiental, além de manter a unidade de manejo dotada da infraestrutura mínima que a mantenha atrativa perante outros possíveis concessionários.

Também se vislumbra o princípio da precaução como fundamento da existência dos citados bens reversíveis, na medida em que manutenção da infra-estrutura necessária a condução do manejo florestal sustentável evita a ocorrência de dano ao meio ambiente.

A complexidade do manejo florestal sustentável, que exige uma série de estudos técnicos (desde relatório ambiental preliminar a estudo prévio de impacto ambiental, inventário amostral, plano de manejo entre outros), licenciamento ambiental, por si só comprova a necessidade de, ao final de uma concessão florestal, seja por qual motivo for, deve ser mantida a infra-estrutura mínima para a continuidade da atividade.

Por outro lado, a desmobilização da infra-estrutura mínima indispensável à atividade de manejo sustentável da floresta pública, pela não manutenção dos bens reversíveis previamente indicados no edital e disciplinados no termo contratual, poderia causar uma perda significativa de qualidade ambiental ou, até mesmo, dano ambiental.

E, o custo social do dano ambiental é elevado, daí a importância da prevenção no empreendimento, pois "De fato, a prevenção é preceito fundamental, uma vez que os danos ambientais, na maioria das vezes, são irreversíveis e irreparáveis.", conforme lição de Celso Antonio Pacheco Fiorillo ${ }^{273}$.

No fundo, verifica-se que o ponto em comum do regime de reversão nas concessões de interesse público e nas concessões florestais, que é o interesse público pela continuidade da atividade em si, para atender uma necessidade pública.

A continuidade do manejo florestal sustentável, garantida pela existência dos bens reversíveis na concessão florestal, atende a necessidade pública de manutenção do equilíbrio ecológico, da qualidade do meio ambiente sustentável.

Verifica-se na própria descrição do conteúdo mínimo dos bens reversíveis, conforme relacionados no artigo 43, do Regulamento da Lei Geral de Gestão de Florestas Públicas (demarcação da unidade de manejo, a infra-estrutura de acesso, as cercas, aceiros,

${ }^{273}$ Curso de Direito Ambiental, São Paulo: Saraiva, 2008. p. 49 
porteiras, construções e instalações permanentes), que eles visam não permitir a degradação da unidade de manejo e, conseqüentemente, a degradação ambiental.

A reversão na concessão florestal, assim como ocorre na concessão de serviço público, deve ser indenizada, para que não se configure um confisco do patrimônio do concessionário.

$\mathrm{Na}$ indenização dos bens reversíveis na concessão florestal pode ser adotada a mesma solução da concessão de serviço público, apontada por Maria Sylvia Zanella Di Pietro ${ }^{274}$, por meio de uma amortização paulatina, no decorrer do prazo do contrato.

Entretanto, no caso da concessão de serviço público, na composição da tarifa uma parte pode ser reservada para tal fim, enquanto, na concessão florestal, por não haver contraprestação nenhuma de um usuário ao concessionário, a referida amortização deve compor o próprio preço florestal.

O poder concedente, assim, quando compuser o preço florestal mínimo, item este que também deve constar no edital (artigo 20, inciso XII, da Lei Geral de Gestão de Florestas Públicas) deverá nele contemplar um desconto para a finalidade de indenização do concessionário pelos bens reversíveis.

Em verdade, isto não é uma novidade nas concessões de uso de bens públicos, quando, por exemplo, o concessionário do espaço público necessita nele erigir uma infra-estrutura indispensável ao exercício de sua atividade econômica, como, por exemplo, a instalação de equipamentos para uma lanchonete, restaurante ou agência bancária, hipótese em que o poder público pode conceder um desconto no preço público por determinado período, com o objetivo de indenizar o concessionário pelo que despendeu para montar a referida infra-estrutura.

No artigo 21, da Lei Geral de Gestão de Florestas Públicas, é previsto que as garantias devem incluir a cobertura de eventuais danos causados ao meio ambiente, erário e terceiros, e podem também incluir a cobertura do desempenho do concessionário em termos de produção florestal e, segundo seu $\S 1^{0}$, tais garantias devem ser suficientes e compatíveis com os ônus e riscos envolvidos nos contratos de concessão florestal.

Pela descrição das finalidades, conclui-se que se trata de garantia para execução do contrato, tal qual aquela prevista no artigo $56, \S 1^{\circ}$, Lei Geral de Licitações e Contratos Administrativos, e não de garantia para participação na licitação, conforme

${ }^{274}$ Op. cit., p. 108 
aquela prevista no artigo 31, inciso III, da citada lei das licitações em geral, exigida na fase de habilitação.

No artigo 47, parágrafo único, do Regulamento da Lei Geral de Gestão de Florestas Públicas, encontra-se previsão de "garantia da proposta" com o objetivo de assegurar que o vencedor do processo licitatório firme, no prazo previsto no edital, o contrato de concessão nos termos da proposta vencedora, à qual se encontra vinculado", sem prejuízo da aplicação das penalidades cabíveis.

Nesse dispositivo, no "caput", também se encontra regra geral no sentido que a implementação e hipóteses de execução das garantias, previstas no art. 21, da Lei Geral de Gestão de Florestas Públicas, deverão ser especificadas mediante resolução do Serviço Florestal Brasileiro.

Entende-se que a citada "garantia de proposta" equivale à garantia para execução do contrato e não à garantia para participação na licitação.

Em relação à garantia para participação na licitação, prevista no artigo 31, inciso III, da Lei Geral de Licitações e Contratos Administrativos, Marçal Justen Filho 275 entende que é “(...) incompatível com o disposto no art. 37, inc. XXI, da CF/88” que resguarda o princípio da competitividade pelo estabelecimento de regra proibitiva de restrições a interessados em participar da licitação, asseverando, porém, que atualmente tem sido atenuado tal posicionamento, pois muitos têm nela vislumbrada uma forma de comprovação da capacidade econômico-financeira do licitante, pois “(...) a impossibilidade de obtenção da garantia prevista no inc. III comprovaria a absoluta ausência de idoneidade do sujeito.".

Diante disto, o estabelecimento de garantia para participação na licitação para concessão florestal pode, em tese, ser estabelecida com fundamento na regra incidente sobre as licitações em geral, mais a garantia para execução do contrato prevista no regramento próprio da concessão florestal, em que pese haver silêncio sobre isso tanto na lei, quanto em seu decreto regulamentador.

As modalidades de garantia, previstas no artigo $21, \S 2^{\underline{0}}$ da Lei Geral de Gestão de Florestas Públicas são:

a) caução em dinheiro; 
b) títulos da dívida pública emitidos sob a forma escritural, mediante registro em sistema centralizado de liquidação e de custódia autorizado pelo Banco Central do Brasil, e avaliados pelos seus valores econômicos, conforme definido pelo Ministério da Fazenda;

c) seguro-garantia;

d) fiança bancária;

e) outras admitidas em lei.

As modalidades de garantia previstas na Lei Geral de Gestão de Florestas Públicas são idênticas àquelas previstas no artigo $56, \S 1^{\circ}$, da Lei Geral de Licitações e Contratos Administrativos, podendo ter havido, portanto, apenas previsão de remissão ao citado dispositivo legal da regra aplicável às licitações em geral.

Para a garantia de execução da concessão florestal também não foi prevista uma regra limitadora do seu montante, tais como os $\S \S 2^{\circ}$ e $3^{\circ}$, da Lei Geral de Licitações e Contratos Administrativos, que prevêem, no máximo e respectivamente, 5\% (cinco por cento) e $10 \%$ (dez por cento) do valor do contrato, este último percentual para obras, serviços e fornecimentos de grande vulto, envolvendo alta complexidade técnica e riscos financeiros consideráveis, desde que com demonstração de tal fato em parecer técnico aprovado pela autoridade competente.

Dada a regra de possibilidade de aplicação subsidiária da Lei Geral de Licitações e Contratos Administrativos na concessão florestal, tais percentuais poderão ser adotados, até que ocorra a regulamentação por resolução do Serviço Florestal Brasileiro com base na regra retro aludida.

Aponta-se, apenas, que tal resolução deverá observar os limites da Lei Geral de Licitação e Contratos Administrativos, em razão do princípio da hierarquia das normas.

Ainda sobre o tema garantias, o artigo $21, \S 3^{0}$ da Lei Geral de Gestão de Florestas Públicas foi prevista a possibilidade de formas alternativas para disciplinar a fixação de garantias e preços florestais, em regulamento.

\subsubsection{Universo de licitantes:}

Na definição do conceito legal de concessão florestal, constante no artigo $3^{\circ}$, inciso VII, da Lei Geral de Gestão de Florestas Públicas, foi explicitado que o concessionário florestal sempre deverá ser uma pessoa jurídica, em consórcio ou não, conceito este dissecado no tópico 5.1, deste Capítulo. 
Para possibilitar a participação das comunidades locais na licitação para concessão florestal, o artigo $6^{\circ}, \S 2^{\circ}$, da Lei Geral de Gestão de Florestas Públicas, determina que elas devem ser constituídas na forma de pessoa jurídica, como associação comunitária, cooperativa ou outra forma permitida em lei, assunto este abordado no tópico 4.3.5, do Capítulo 4.

Em relação a todas essas categorias de participantes é exigida a constituição sob as leis brasileiras, assim como a sede e administração no Brasil, por imposição do artigo $19, \S 1^{\circ}$ e artigo 79 , ambos da Lei Geral de Gestão de Florestas Públicas.

Portanto, dessa primeira delimitação dos licitantes, conclui-se que somente pessoas jurídicas brasileiras, com sede e administração no Brasil é que podem participar da licitação para concessão florestal, sendo vedada a participação de estrangeiros.

Quanto ao estabelecimento de restrição à participação de estrangeiros em licitação pública, trata-se de assunto que já rendeu bastante discussão, hoje estando mais pacífico o entendimento que não há descumprimento ao princípio constitucional da isonomia, na fixação de preferências às empresas brasileiras, uma vez que tal princípio só garante a isonomia entre brasileiros e estrangeiros em matéria de direitos fundamentais.

Sob o ponto de vista pragmático, entretanto, vislumbra-se a possibilidade do capital estrangeiro alimentar empresas constituídas sob a lei brasileira, burlando-se o propalado fim da norma legal, de se evitar a "internacionalização" da floresta pública brasileira.

No mesmo sentido é a opinião de Maria Luiza Machado Granziera ${ }^{276}$, que entende que a lei não impede que grupos estrangeiros, por intermédio de empresas constituídas sob o direito pátrio e com sede no Brasil, mas sob seu controle, participem da licitação.

A Lei Geral de Gestão de Florestas Públicas, no seu artigo 22, também permite a participação de pessoas jurídicas em consórcio, desde que:

a) comprovado o estabelecimento de compromisso de constituição de consórcio, por instrumento público ou particular subscrito pelas consorciadas;

b) indicada a empresa-líder que deve observar as condições de liderança estipuladas no edital e ser representante das consorciadas perante o poder concedente;

\footnotetext{
${ }^{276}$ Mecanismos de efetividade da lei sobre florestas públicas, in Revista de Direito Ambiental, ano 13, n. 49, jan.-mar./2008, p. 201-216
} 
c) apresentados os documentos de aferição da capacidade técnica, idoneidade financeira e regularidade jurídica e fiscal de todas as consorciadas.

Deve-se notar que é impedida a participação de empresas consorciadas na mesma licitação por intermédio de mais de um consórcio ou isoladamente (artigo 22, inciso V, da mesma Lei), ou seja, se uma empresa optar por participar de um consórcio é impedida de participar de outro ou participar sozinha da licitação.

Após vencer a licitação e antes de celebrar o contrato de concessão florestal, o consórcio é obrigado a promover sua constituição legal e registro público, nos termos do compromisso assumido e toda e qualquer alteração na sua constituição deve ser submetida ao poder concedente previamente para verificação da manutenção das condições de habilitação, sob pena de rescisão do contrato (artigo $22, \S \S 1^{\circ}$ e $3^{\circ}$, da Lei).

Renato Poltronieri ${ }^{277}$, comentando o teor do artigo 33, da Lei $\mathrm{n}^{\circ} 8.666$, de 21de junho de 1993 (Lei Geral de Licitações e Contratos Administrativos), que permite também a participação de empresas em consórcio nas licitações em geral, ressalta que o regramento dos consórcios de empresas no Brasil encontra-se na Lei $n^{\circ}$ 6.404, de 15 de dezembro de 1976 (Lei das Sociedades Anônimas) e que sua principal característica, como nos demais países, é a "despersonalidade", ou seja, "não possui personalidade jurídica, não sendo, portanto, um sujeito de direito tampouco apto a assumir responsabilidades”.

Apesar da inexistência de personalidade jurídica, as "ações representam as ações de seus componentes, o que permite uma fiscalização por parte da Administração, especialmente com relação aos objetivos do ente consorciado criado".

A pessoa jurídica líder é responsável pelo cumprimento da concessão florestal perante o poder concedente, sem prejuízo da responsabilidade solidária de cada consorciada (artigo 22, §2 $2^{\circ}$, da Lei).

A Lei Geral de Gestão de Florestas Públicas refere-se à "empresa-líder", dando a entender que um consórcio só poderia ser constituído pela associação de empresas.

Vislumbra-se, entretanto, a possibilidade de consórcio entre outras espécies de pessoas jurídicas, como associações de comunidades locais, fundações, cooperativas e associações qualificadas como organizações da sociedade civil de interesse público ou organizações sociais, desde que permitidas por seus atos constitutivos.

As pessoas jurídicas que não se dedicarem a atividade lucrativa, porém, deverão necessariamente consorciar-se com pelo menos uma empresa, uma vez que a

${ }^{277}$ Licitação e Contratos Administrativos, segundo o Direito Positivo. São Paulo: Editora Juarez de Oliveira, 2004, p. 133-134 
concessão florestal é atividade econômica e não apenas social, ou melhor, é atividade econômica e sócio-ambiental.

Deste modo, vislumbra-se a possibilidade de uma série de arranjos num consórcio para participação na licitação para concessão florestal, em que, por exemplo, na futura contratação as organizações não governamentais possam se dedicar a atividades sócio-ambientais, educativas, sem conflitar com o objeto principal do manejo florestal sustentável.

Não há impedimento também para que empresas de pequeno porte e microempresas se consorciem com a finalidade de concorrer à concessão florestal, neste caso, apenas, devendo o órgão gestor velar pela preservação do princípio da igualdade e competitividade na licitação, uma vez que a Lei Geral de Gestão de Florestas Públicas e o Estatuto das Microempresas e Empresas de Pequeno Porte conferem uma série de prerrogativas a tais espécies empresariais.

A constituição de sociedade de propósito específico é facultada pelo artigo 23, da Lei Geral de Gestão de Florestas Públicas, desde que autorizado no edital e antes da celebração do contrato.

Neste ponto, indispensável a menção à orientação de Maria Sylvia Zanella Di Pietro ${ }^{278}$ que, ao analisar dispositivo semelhante da Lei Geral de Concessões e Permissões (de serviço público) concluiu que, muitas vezes o interesse público pode exigir a constituição de sociedade de propósito específico, afastando-se a discricionariedade, para melhor execução do serviço público:

O dispositivo já foi comentado (...) onde foi ressaltado que, embora a lei faculte ao poder público fazer a exigência no edital de licitação, nem sempre se trata de mera faculdade discricionária, pois, se o interesse público o exigir, existe a obrigatoriedade de inclusão no edital. Na prática, essa exigência tem sido feita como regra geral." (itálico do original, grifo nosso)

Do trecho doutrinário transcrito, conclui-se que, também na concessão florestal, a realidade poderá exigir que seja prevista a obrigatoriedade de constituição de uma sociedade de propósitos específicos para melhor condução do manejo florestal sustentável.

\footnotetext{
${ }^{278}$ Parcerias na Administração Pública, Concessão, Permissão, Franquia, Terceirização, Parceria PúblicoPrivada e outras formas, São Paulo: Atlas, 2006. p. 179
} 
Neste caso, o órgão gestor deve prever a obrigação de constituição de sociedade de propósito específico, principalmente se permitido o consórcio com outras pessoas jurídicas, sem fins lucrativos, como as citadas associações de comunidades locais, cooperativas, fundações, organizações sociais e organizações da sociedade civil de interesse público.

Merece menção o fato que a participação de empresas em consórcio é disciplinada ainda no artigo 20, da Lei n 8.987, de 13 de fevereiro de 1995 (Lei Geral de Concessões e Permissões), tendo por objetivo esta norma a separação de recursos públicos dos privados e, com isso, a melhor gestão do serviço público, quando assim exigir o interesse público.

No caso da concessão florestal, semelhante pensamento pode ser elaborado, pois a constituição de uma sociedade de propósitos específicos, ou mesmo a constituição de uma nova empresa "mediante cisão ou criação de uma subsidiária integral", como aventado por Maria Sylvia Zanella Di Pietro ${ }^{279}$ ao comentar o referido dispositivo legal da Lei Geral de Concessões e Permissões, pode proporcionar melhor execução do manejo florestal sustentável, se assim for considerado pelo órgão gestor e poder concedente.

Na mesma toada, Rafael Véras de Freitas ${ }^{280}$ explica que a “"joint venture’ (...) não implica perda da identidade e individualidade da empresa" e que "não há, pois, qualquer margem de dúvida acerca da vantajosidade da criação de uma SPE, em parceria com o Poder Público, para o desenvolvimento da atividade das concessões florestais, pois com a criação de uma pessoa jurídica autônoma ocorrerá a segregação dos riscos do empreendimento".

A participação de pessoas jurídicas de pequeno porte, micro e médias empresas também é estimulada na Lei Geral de Gestão de Florestas Públicas, tanto que, em seu artigo 33, é previsto que o Plano Anual de Concessão Florestal deve definir lotes de concessão compostos por várias unidades de manejo de tamanhos diversos.

Além de tal regra, no artigo 74 da mesma Lei, foi previsto que os parâmetros para definição de tais tamanhos deveriam ser definidos em regulamento antes da aprovação do primeiro Plano Anual de Outorga Florestal.

Tais disposições estão em consonância com o regramento inaugurado pela Lei Complementar $\mathrm{n}^{\circ}$ 123, de 14 de dezembro de 2006 (Estatuto da Microempresa e

${ }^{279}$ Op. cit. p. 137
Loc. cit. 
Empresa de Pequeno Porte) que, em especial, na matéria relativa às licitações, conferiu a microempresa e empresa de pequeno porte benefícios, tais como possibilidade de regularização fiscal tardia e lance suplementar em caso de empate ficto, que são de observância obrigatória pela Administração Pública em qualquer modalidade de licitação.

Em relação ao tema, vale transcrever a lição de Marçal Justen Filho ${ }^{281}$ :

Os referidos benefícios são de observância obrigatória por todas as entidades administrativas que promovem licitações. A fruição dos benefícios por parte das ME e das EPP não se subordina a alguma decisão discricionária da Administração Pública. Trata-se de determinação legal imperativa, derivada do exercício pela União de sua competência legislativa privativa para editar normas gerais sobre licitação $(\mathrm{CF} / 88$, art. 22, inc. XXXVI). (grifo nosso)

Da mesma forma, as prerrogativas existentes na Lei Geral de Gestão de Florestas Públicas em favor das microempresas e empresas de pequeno porte devem ser obrigatoriamente inseridas nos editais de licitação para concessão florestal.

Os referidos tamanhos das unidades de manejo, por sua vez, devem ser estabelecidos com base em critérios técnicos, levando-se em conta as condições e necessidades do setor florestal, peculiaridades regionais, estrutura das cadeias produtivas, infra-estruturas locais e o acesso aos mercados.

Reitera-se, também, que no artigo $21, \S 3^{\circ}$, da mesma Lei, foi estabelecida a possibilidade de formas alternativas de fixação de garantias e preços florestais para concessionárias pessoas jurídicas de pequeno porte, microempresas e associações de comunidades locais.

No edital também são indicados os valores de estudos, levantamentos, projetos, obras, despesas ou investimentos efetuados na unidade de manejo e vinculados à licitação que devem ser ressarcidos pelo vencedor da licitação, estando dispensadas de tal ressarcimento as empresas de pequeno porte, microempresas e associações de comunidades locais, conforme artigo $24, \S \S 1^{\circ}$ e $2^{\circ}$, da Lei Geral de Gestão de Florestas Públicas.

Para o cálculo do referido preço de ressarcimento, o artigo 37, do Regulamento da Lei Geral de Gestão de Florestas Públicas, previu que deve ser definido com base no custo médio do edital por hectare, considerando os custos do inventário florestal, dos estudos preliminares contratados especificamente para compor o edital, do

${ }^{281}$ O Estatuto da Microempresa e as Licitações Públicas, São Paulo: Dialética, 2007. p. 21 
relatório ambiental preliminar - RAP, do processo de licenciamento e da publicação e julgamento das propostas.

Entretanto, deve ser excluído do chamado custo do edital aqueles relacionados às ações do poder público que, por sua natureza, geram benefícios permanentes ao patrimônio público.

\subsubsection{Fase de habilitação:}

A fase de habilitação é uma fase intermediária, que ocorre após a entrega dos envelopes pelos licitantes e tem por objetivo averiguar se são aptos a participar das fases seguintes.

Nesta fase são analisadas a habilitação jurídica, regularidade físcal, qualificação técnica e qualificação econômico-financeira, conforme artigos 28 a 31, da Lei Geral de Licitações e Contratos Administrativos, aplicáveis também à concessão florestal.

Em relação a tal fase, a Lei Geral de Gestão de Florestas Públicas inovou, pois estabeleceu em seu artigo 19, incisos I e II, além do cumprimento das normas aplicáveis às licitações em geral retro citadas, a comprovação de ausência de:

a) débitos inscritos na dívida ativa relativos a infração ambiental nos órgãos competentes integrantes do Sistema Nacional do Meio Ambiente - SISNAMA;

b) decisões condenatórias, com trânsito em julgado, em ações penais relativas a crimes contra o meio ambiente, a ordem tributária ou previdenciários, respeitada a reabilitação prevista no artigo 93, do Código Penal.

Quanto a citada comprovação de ausência de débitos inscritos na dívida ativa relativos a infração ambiental, prevê o artigo 33, do Regulamento da Lei Geral de Gestão de Florestas Públicas, que deverá ser feito por meio de documentos emitidos pelos órgãos integrantes do SISNAMA da localização das unidades de manejo pretendidas e da sede do licitante.

Também prevê que a emissão de tais documentos deve ser feita, preferencialmente, por meio da rede mundial de computadores, nos termos do Decreto $\mathrm{n}^{\mathrm{o}}$ 5.975, de 30 de novembro de 2006.

Em conformidade com o exposto neste trabalho, no tópico 1.8.1, no Capítulo 1, este decreto regulamenta vários dispositivos do Código Florestal e da Lei Geral de Gestão de Florestas Públicas, disciplinando, especialmente, assuntos como o plano de manejo florestal sustentável, os regimes de supressão a corte raso de florestas e formações sucessoras para uso 
alternativo do solo, a utilização de matéria-prima florestal, a obrigação de reposição florestal e a licença para transporte de produtos e subprodutos florestais de origem nativa e, finalmente, a publicidade de informações por meio da "internet".

\subsubsection{Fase de classificação das propostas e julgamento:}

Na fase de classificação a Administração Pública, por intermédio da comissão de licitação, avalia as propostas técnicas, quanto aos aspectos tecnológicos, meios de execução do objeto da licitação, conforme os critérios definidos em edital e encaminha o procedimento para a fase seguinte, de análise das propostas comerciais, a fase de julgamento.

Nos artigos 46, $\S \S 1^{\circ}$ e $2^{\circ}$, da Lei Geral de Licitações e Contratos Administrativos, é definido o procedimento da fase de classificação, utilizada somente nas licitações do tipo "melhor técnica" e "técnica e preço", com abertura prévia das propostas técnicas e, posteriormente, as propostas de preço.

A disciplina dos critérios de julgamento na licitação para concessão florestal, constante na Lei Geral de Gestão de Florestas Públicas é diferenciada em relação às normas aplicáveis às licitações em geral.

No artigo 26, da Lei Geral de Gestão de Florestas Públicas, é previsto que no julgamento da licitação, a melhor proposta será considerada em razão da combinação dos critérios de maior preço ofertado como pagamento ao poder concedente pela outorga da concessão florestal e melhor técnica.

No inciso II, do referido dispositivo, apresenta-se o que deve ser considerado para a aferição da melhor técnica:

a) o menor impacto ambiental;

b) os maiores benefícios sociais diretos;

c) a maior eficiência;

d) a maior agregação de valor ao produto ou serviço florestal na região da concessão.

Portanto, na licitação para concessão florestal pode-se afirmar a existência de duas etapas definidas na fase de classificação da proposta, a primeira técnica, para contemplar os requisitos retro referidos, exigidos na lei, e a segunda, que contempla a proposta de maior preço ofertado como contraprestação ao uso da área objeto da concessão florestal. 
A Lei de Geral de Gestão de Florestas Públicas inovou ao adotar a combinação dos critérios de maior preço com o de melhor técnica, em relação aos critérios previstos no artigo 45, da Lei Geral de Licitações e Contratos Administrativos, de forma semelhante ao que foi adotado no artigo 15, da Lei Geral de Concessões e Permissões de Serviço Público.

Conforme disciplina uniforme para todas as espécies de licitação, sejam as comuns ou para concessão de serviço público, nas concessões florestais os referidos critérios devem sempre ser estabelecidos no edital de licitação, com regras e fórmulas precisas para avaliação ambiental, econômica, social e financeira, assim como os parâmetros e exigências para formulação de propostas técnicas, devendo o poder concedente recusar propostas manifestamente inexeqüíveis ou financeiramente incompatíveis com os objetivos da licitação (artigo $26, \S \S 1^{\circ}$ a $3^{\circ}$, da Lei Geral de Gestão de Florestas Públicas).

No artigo 35, do Regulamento da Lei Geral de Gestão de Florestas Públicas, houve repetição do inteiro teor do citado artigo 26, porém, com melhor aclaramento do critério melhor técnica.

Em tal dispositivo esclarece-se que, no menor impacto ambiental deve ser analisado o menor impacto negativo ou o maior impacto positivo, na maior eficiência a derivada do uso dos recursos florestais e conceituou a região de concessão como os Municípios abrangidos pelo lote de concessão, para fins de aferição do critério maior agregação de valor ao produto ou serviço florestal.

$\mathrm{Na}$ concessão florestal foi adotado um sistema de avaliação da melhor oferta baseado em indicadores, composto por pelo menos um indicador para cada um dos critérios de melhor preço e melhor técnica, segundo o artigo 36, "caput" e $\S 1^{\circ}$, do Regulamento da Lei Geral de Gestão de Florestas Públicas.

Tais indicadores poderão ser utilizados para fins de pontuação para definição da melhor proposta ou para fins de bonificação e deverão ter as seguintes características:

a) ser objetivamente mensuráveis;

b) relacionar-se a aspectos de responsabilidade direta do concessionário; e

c) ter aplicabilidade e relevância para avaliar o respectivo critério, conforme o $\S 2^{\circ}$, do citado dispositivo legal.

Tomando-se por base os indicadores, a melhor oferta é aferida por uma fórmula precisa de cálculo prevista no edital e a metodologia de pontuação máxima deverá 
ser montada de tal forma a garantir que o peso de cada critério não seja menor que um ou maior que três, sejam os critérios de melhor preço e melhor técnica, sejam aqueles que definem o de melhor técnica ( $\S 3^{\circ}$ e $4^{\circ}$, do citado artigo). O peso do critério de melhor técnica deve ser maior ou igual ao peso do critério de melhor preço $\left(\$ 5^{\circ}\right.$, do mesmo artigo).

Ainda sobre os indicadores dos critérios de julgamento da licitação para concessão florestal, os seus objetivos devem ser eliminatório, classificatório e bonificador, conforme prevê o $\S 6^{\circ}$, do aludido artigo, quando, respectivamente, indicar parâmetros mínimos a serem atingidos para a qualificação do concorrente, pontuação no julgamento das propostas, durante o processo licitatório e, finalmente, para atingimento de bonificação na execução do contrato pelo concessionário.

Toshio Mukai ${ }^{282}$ entende que a discussão sobre os critérios de seleção é assunto "dos mais problemáticos em qualquer legislação que disponha sobre o julgamento das licitações, eis que existem nela sempre critérios que levam ao subjetivismo nos julgamentos", exemplificando com o que ocorre nos tipos de licitações de melhor técnica e técnica e preço da Lei Geral de Licitações e Contratos Administrativos.

No caso específico da licitação para concessão florestal, quanto à regra do artigo 26, § 2º da Lei n $^{\circ}$ 11.284, de 02 de março de 2006 (Lei Geral de Gestão de Florestas Públicas), entendo o doutrinador que, apesar do citado artigo prever a necessidade de parâmetros e exigências para formulação das propostas técnicas, estes, "por mais que sejam precisos, não terão o condão de retirar do julgamento técnico toda a subjetividade natural de que ele se compõe".

Realmente, o doutrinador tem razão ao considerar que qualquer julgamento técnico é caracterizado por determinada margem de subjetividade, contudo, deve-se observar que a Lei Geral de Gestão de Florestas Públicas e seu regulamento procuraram fixar regras que contemplam o princípio da razoabilidade na fixação e apreciação de tais parâmetros, sem prejuízo de tal aspecto ser aferido por órgão de controle externo.

Maria Luiza Machado Granziera ${ }^{283}$, ao analisar os critérios de julgamento da melhor proposta em concessão florestal, defende que o critério maior preço não pode alterar o julgamento calcado no critério de melhor técnica e sugere a adoção, nos editais de licitação, de “ponderações da ordem 9 para 1, por exemplo, na relação proposta técnica -

\footnotetext{
${ }^{282}$ Licitações nas Concessões Florestais, in Revista JML de Licitações e Contratos, Ano I, nº 02, mar. 2007, p. 18-21

${ }^{283}$ Mecanismos de efetividade da lei sobre florestas públicas, in Revista de Direito Ambiental, ano 13, n. 49, jan.-mar./2008, p. 201-216
} 
preço, pois esse tipo de ponderação minimizaria a importância do fator preço ofertado, privilegiando a proposta técnica".

Para a doutrinadora, a decisão de desenho do edital da forma sugerida é discricionária, porém, lembrou que "cabe ao administrador público buscar a alternativa mais próxima da finalidade da licitação: a garantia de que a melhor proposta apresentada não seja preterida em função de um valor monetário oferecido para obter o direito de explorar a floresta".

\subsection{Regramento do contrato de concessão florestal:}

Assim como procedido em relação à licitação para concessão florestal, no presente tópico do trabalho são focadas apenas as regras específicas, aplicáveis a tal tipo de contratação, em comparação com o regramento genérico.

\subsubsection{Prévia existência do Plano de Manejo Florestal Sustentável - PMFS:}

A aprovação de Plano de Manejo Florestal Sustentável, pelo órgão competente do Sistema Nacional do Meio Ambiente - SISNAMA, é requisito indispensável para o início das operações de exploração de produtos e serviços florestais, conforme regra do artigo 32, §2 , da Lei Geral de Gestão de Florestas Públicas.

Complementando tal regra, o artigo 41, do Regulamento da Lei Geral de Gestão de Florestas Públicas, prevê que no edital de licitação deve ser estipulado um prazo máximo de doze meses para que o concessionário apresente o Plano de Manejo Florestal Sustentável ao órgão competente, após assinatura do termo de contrato de concessão.

A disciplina jurídica do referido Plano de Manejo Florestal Sustentável PMFS é encontradiça no Decreto $n^{\circ} 5.975$, de 30 de novembro de 2006 e foi analisada no item 1.81., do Capítulo 1, deste trabalho, uma vez que trata de instrumento necessário ao regime de manejo florestal sustentável.

Conforme se pode extrair das regras básicas, a entrega do Plano de Manejo Florestal Sustentável é uma condição para que o concessionário florestal possa iniciar as atividades da concessão florestal, sendo que sua não apresentação pelo concessionário, no prazo indicado no edital, poderá ser considerada inexecução total do contrato, com as conseqüências previstas nos artigos 77 e seguintes da Lei Geral de Licitações e Contratos Administrativos. 
O poder concedente, para formalizar a rescisão contratual deverá promover processo administrativo, com ampla defesa e contraditório, podendo também, em tese, ser aplicadas penalidades contratuais, conforme artigo 87, da Lei Geral de Licitações e Contratos Administrativos.

\subsubsection{Cláusulas obrigatórias do termo contratual:}

O artigo 30, da Lei Geral de Gestão de Florestas Públicas prevê que são cláusulas essenciais do termo de contrato de concessão florestal as relativas:

a) ao objeto, com a descrição dos produtos e dos serviços a serem explorados e da unidade de manejo;

b) ao prazo da concessão;

c) ao prazo máximo para o concessionário iniciar a execução do PMFS;

d) ao modo, à forma, às condições e aos prazos da realização das auditorias florestais;

e) ao modo, à forma e às condições de exploração de serviços e prática do manejo florestal;

f) aos critérios, aos indicadores, às fórmulas e aos parâmetros definidores da qualidade do meio ambiente;

g) aos critérios máximos e mínimos de aproveitamento dos recursos florestais;

h) às ações de melhoria e recuperação ambiental na área da concessão e seu entorno assumidas pelo concessionário;

i) às ações voltadas ao benefício da comunidade local assumidas pelo concessionário;

j) aos preços e aos critérios e procedimentos para reajuste e revisão;

k) aos direitos e às obrigações do poder concedente e do concessionário, inclusive os relacionados a necessidades de alterações futuras e modernização, aperfeiçoamento e ampliação dos equipamentos, infra-estrutura e instalações;

1) às garantias oferecidas pelo concessionário;

m) à forma de monitoramento e avaliação das instalações, dos equipamentos, dos métodos e práticas de execução do manejo florestal sustentável e exploração de serviços;

n) às penalidades contratuais e administrativas a que se sujeita o concessionário e sua forma de aplicação;

o) aos casos de extinção do contrato de concessão;

p) aos bens reversíveis;

q) às condições para revisão e prorrogação; 
r) à obrigatoriedade, à forma e à periodicidade da prestação de contas do concessionário ao poder concedente;

s) aos critérios de bonificação para o concessionário que atingir melhores índices de desempenho socioambiental que os previstos no contrato, conforme regulamento;

t) ao foro e ao modo amigável de solução das divergências contratuais.

A regra geral, prevista no artigo 27, da Lei Geral de Gestão de Florestas Públicas é no sentido de que seja adotado para cada unidade de manejo licitada um contrato de concessão florestal, exclusivo com um único concessionário, sendo vedada a subconcessão $\left(\S 4^{\circ}\right.$, do mesmo artigo).

Portanto, conforme opinião comungada por Toshio Mukai ${ }^{284}$, a concessão florestal é uma concessão "inteiramente 'intuitu personae"”, não ocorrendo o mesmo em outras espécies de concessão.

Maria Sylvia Zanella Di Pietro ${ }^{285}$, no âmbito da concessão de serviço público, explica que a subconcessão possui a mesma natureza jurídica da concessão, de direito público, sendo "um contrato celebrado à imagem da concessão a que se vincula" e implica também em outorga de "poderes do subconcedente para o subconcessionário, de tal modo que assume as mesmas prerrogativas, os mesmos encargos e mesmas responsabilidades".

Primeiramente, há de se diferenciar que a subconcessão é autorizada na concessão de serviço público, no artigo 25, "caput", da Lei no 8.987, de 13 de fevereiro de 1995 (Lei de Concessões e Permissões), desde que com a concordância do poder concedente, o mesmo não ocorrendo em relação à concessão florestal, onde, ao contrário, é vedada expressamente na lei.

Em segundo lugar, tem-se que na concessão de serviço público o concessionário é investido de certos poderes, necessários à gestão do serviço público, que conferem prerrogativas, tais como possibilidade de desapropriar, instituir servidões, administrar receitas públicas e exercer poder de polícia sobre bens, que não se verificam na concessão florestal.

Portanto, o regramento próprio da subconcessão de serviço público não se aplica à concessão florestal.

\footnotetext{
${ }^{284}$ Os Contratos de Concessões Florestais, in Boletim de Licitações e Contratos, Editora NDJ Ltda., Ano XIX, nº 10, out. 2006.

${ }^{285}$ Parcerias na Administração Pública, Concessão, Permissão, Franquia, Terceirização, Parceria PúblicoPrivada e outras Formas, São Paulo: Atlas, 2006. p. 127
} 
O concessionário deve ser responsável por todas as obrigações contratuais e responde pelos prejuízos causados ao poder concedente, ao meio ambiente ou a terceiros, não sendo tal responsabilidade excluída ou atenuada pela fiscalização do poder concedente ou órgãos competentes.

Tal regra, em verdade, é quase que idêntica àquela constante no artigo 70, da Lei $\mathrm{n}^{\mathrm{o}}$ 8.666, de 21 de junho de 1993 (Lei Geral de Licitações e Contratos Administrativos),

Também é permitida a contratação de terceiros para o desenvolvimento de atividades inerentes ou subsidiárias ao manejo florestal sustentável dos produtos e à exploração dos serviços florestais concedidos, sem prejuízo da aludida responsabilidade do concessionário, devendo tais contratações ser regidas pelo direito privado.

Além disso, tais contratações não envolvem o poder concedente, sendo estabelecidas exclusivamente entre o concessionário e terceiros e deverão observar normas regulamentares relacionadas a essas atividades.

Em tais contratações, quando estabelecidas no âmbito da concessão de serviço público, explica Maria Sylvia Zanella Di Pietro ${ }^{286}$ o concessionário continua respondendo pelos serviços terceirizados perante o poder concedente e o usuário.

Semelhante raciocínio pode ser deduzido em relação às terceirizações em concessões florestais, na disciplina da responsabilidade do concessionário florestal perante o poder concedente, uma vez que não existe a figura do usuário em tal espécie de concessão.

O artigo 44, do Regulamento da Lei de Gestão de Florestas Públicas, define quais devem ser consideradas atividades inerentes ao manejo florestal, para o fim da contratação de serviços de terceiros retro referida, a saber:

a) planejamento e operações florestais, incluindo a elaboração do inventário florestal, do Plano de Manejo Florestal Sustentável, do planejamento operacional, a construção e manutenção de vias de acesso e ramais, a colheita e transporte de produtos florestais, a silvicultura pós-colheita, o monitoramento ambiental e a proteção florestal;

b) atividades subsidiárias ao manejo florestal tais como operações de apoio (segurança e vigilância, manutenção de máquinas e infra-estrutura, gerenciamento de acampamentos e proteção florestal), operações de processamento de produtos florestais e operações de serviço (guia de visitação e transporte de turistas).

${ }^{286}$ Direito Administrativo, São Paulo: Atlas, 2008. p. 283 
Quanto ao modo amigável de solução de divergências contratuais, a Lei Geral de Gestão de Florestas Públicas seguiu a trilha do que consta no artigo 23-A, da Lei $n^{\circ}$ 8.987, de 13 de fevereiro de 1995 (Lei de Concessões e Permissões), com redação alterada pela Lei $n^{\circ} 11.196$, de 21 de novembro de 2005, que prevê a submissão do contrato de concessão de serviços públicos a mecanismos privados de resolução de disputas, inclusive a arbitragem, assim como o que consta no artigo 11 , inciso III, da Lei $\mathrm{n}^{\circ}$ 11.079, de 30 de dezembro de 2004 (Lei de Parcerias Público Privadas), que prevê regra semelhante.

Portanto, em mais uma oportunidade, o legislador da Lei Geral de Gestão Pública, para disciplinar um relevante aspecto da espécie de concessão de uso de bem público, a concessão florestal, bebeu na fonte da concessão de serviço público.

E, assim agindo, traz as qualidades e defeitos dos institutos da concessão de serviço público, sendo que, neste caso, merece menção o magistério de Maria Sylvia Zanella Di Pietro, que, analisando a disposição legal impositiva da arbitragem, chamou atenção ao fato que a Lei no 9.307, de 23 de setembro de 1996, que dispõe sobre tal meio de resolução de conflitos, "expressamente afasta essa possibilidade com relação aos interesses indisponíveis".

Desta forma, a doutrinadora conclui: "O certo seria que a lei delimitasse as hipóteses em que a arbitragem pode ser utilizada, restringindo a discricionariedade do poder concedente na elaboração do edital".

Realmente, concorda-se com a doutrinadora que a utilização da arbitragem para a resolução de conflitos que provenham da concessão florestal poderá trazer discussões, ainda mais quando estiver em jogo interesses jurídicos ambientais e sociais, cuja característica de indisponibilidade pode se configurar.

\subsubsection{Direitos e obrigações do concessionário:}

Em que pese o fato das partes contratantes da concessão florestal serem o poder concedente e o concessionário florestal, a Lei Geral de Gestão de Florestas Públicas dedicou-se a estabelecer as obrigações somente do concessionário florestal, agregadas principalmente no seu artigo 31, assim podendo ser resumidas por temas:

a) Plano de Manejo Florestal Sustentável (incisos I e XII): sua elaboração, execução e monitoramento;

b) unidade de manejo florestal (incisos VIII, IX, XI e XIII): 
- realizar benfeitorias necessárias,

- realizar usa manutenção e da infra-estrutura, executar medidas de prevenção e controle de incêndios e

- zelar pela integridade dos bens e benfeitorias vinculados a ela;

c) ecossistema (incisos II e III):

- evitar ações ou omissões geradoras de danos a ele ou a qualquer de seus elementos e

- informar a autoridade competente sobre tais ações ou omissões, próprias ou de terceiros, assim como fatos, que acarretem tais danos;

d) responsabilidade objetiva na recuperação de áreas degradadas (inciso IV): se a degradação tiver nexo de causalidade com suas ações ou omissões, sem prejuízo das responsabilidades contratuais, administrativas, civis ou penais;

e) manejo florestal (incisos V, VI, VII, XIV e XV):

- cumprir e fazer cumprir suas normas, regras de exploração de serviços e cláusulas contratuais,

- garantir a execução do ciclo contínuo, iniciada dentro do prazo máximo fixado no edital, buscar o uso múltiplo da floresta, nos limites contratualmente definidos e observadas as restrições aplicáveis às áreas de preservação permanente e as demais exigências da legislação ambiental,

- manter atualizado o inventário e o registro dos bens vinculados à concessão,

- comercializar o produto florestal auferido do manejo;

- elaborar e disponibilizar o relatório anual sobre a gestão dos recursos florestais ao órgão gestor, nos termos definidos no contrato;

f) submissão à fiscalização e auditoria florestal (inciso XVI): permitir amplo e irrestrito acesso aos encarregados da fiscalização e auditoria, a qualquer momento, às obras, aos equipamentos e às instalações da unidade de manejo, bem como à documentação necessária para o exercício da fiscalização;

g) realizar os investimentos ambientais e sociais definidos no contrato de concessão (inciso XVII).

No contraponto das obrigações, quanto aos direitos do concessionário florestal, prevê o artigo 16, $\S 1^{\circ}$, da Lei Geral de Gestão de Florestas Públicas que a concessão florestal não confere qualquer dos seguintes direitos:

a) titularidade imobiliária ou preferência na aquisição da área objeto da concessão;

b) acesso ao patrimônio genético para fins de pesquisa e desenvolvimento, bioprospecção ou constituição de coleções; 
c) uso dos recursos hídricos acima do especificado como insignificante, nos termos da Lei n 9.433, de 08 de janeiro de 1997 (Lei da Política Nacional dos Recursos Hídricos);

d) exploração dos recursos minerais;

e) exploração de recursos pesqueiros ou da fauna silvestre;

f) comercialização de créditos decorrentes da emissão evitada de carbono em florestas naturais, sendo esta permitida somente no caso de reflorestamento de áreas degradadas ou convertidas para uso alternativo do solo, se incluído no objeto da concessão, nos termos de regulamento ( $\$ 2^{\underline{o}}$, do citado artigo)

As comunidades locais poderão realizar o manejo da fauna silvestre, conforme a legislação específica (artigo 16, $\S 3^{\underline{0}}$, da Lei Geral de Gestão de Florestas Públicas).

Entretanto, no artigo 50, do Regulamento da Lei Geral de Gestão de Florestas Públicas é previsto que o contrato de concessão florestal federal deve também prever os direitos e obrigações para sua integração a contratos, autorizações, licenças e outorgas daqueles direitos que não são incluídos na concessão florestal, retro referidos, disciplinados pelo artigo $16, \S 1^{\circ}$, da citada Lei.

No artigo $31, \S \S 1^{\circ}$ e $3^{\circ}$, da Lei Geral de Gestão de Florestas Públicas também é previsto que, ao fim do contrato de concessão florestal, o concessionário é obrigado a devolver a unidade de manejo ao poder concedente nas condições previstas no termo contratual, sob pena de sofrer sanções contratuais, administrativas, penais, civis e as decorrentes da Lei no 6.938, de 31 de agosto de 1981 (Lei da Política Nacional do Meio Ambiente) e as benfeitorias permanentes devem reverter sem ônus ao titular da área ao final do contrato de concessão, ressalvados os casos previstos no edital de licitação e no contrato de concessão.

Outra importante obrigação do concessionário florestal é a de obter prévia anuência do poder concedente para promover a transferência do controle societário, sob pena de rescisão da concessão florestal, com aplicação das sanções contratuais e execução das garantias oferecidas (artigo 28, da Lei Geral de Gestão de Florestas Públicas).

E, para isto, o concessionário florestal que pretender transferir o controle societário deverá continuar atendendo as exigências da habilitação e comprometer-se a cumprir todas as cláusulas do contrato em vigor, por força do aludido artigo 28, parágrafo único.

Tal regra possui conteúdo assemelhado àquela do artigo 27 , da Lei $\mathrm{n}^{\circ}$ 8.987, de 13 de fevereiro de 1995 (Lei de Concessões e Permissões). 
Todavia, a Lei Geral de Gestão de Florestas Públicas não disciplinou o assunto permitindo a assunção do controle societário da concessionária por financiadores, com a finalidade de promover reestruturação financeira e, com isso, permitir a continuidade da prestação do serviço público ( $\$ 1^{\circ}$ a $4^{\circ}$, do citado artigo).

Comentando tal dispositivo legal, Maria Sylvia Zanella Di Pietro ${ }^{287}$ realça:

Em princípio, não há impedimento à transferência do controle acionário, devendo ser observada a regra do art. 27, (...) que exige anuência do poder concedente; além disso, a transferência do controle acionário deve ser feita de tal modo que não afete as exigências de capacidade técnica, idoneidade financeira e regularidade jurídica e fiscal necessárias à prestação do serviço.

Mesmo referindo-se à concessão de serviço público, a doutrina aplica-se também à concessão florestal, na medida em que sua lei específica, de forma semelhante, cercou o poder concedente de garantias para a manutenção das condições de habilitação e compromisso de cumprimento das cláusulas contratuais.

O concessionário florestal, ainda em relação à unidade de manejo florestal sustentável, deverá destacar uma área geograficamente delimitada destinada à reserva absoluta, representativa dos ecossistemas florestais manejados, equivalente a, no mínimo, 5\% (cinco por cento) do total da área concedida, para conservação da biodiversidade e avaliação e monitoramento dos impactos do manejo florestal, não se incluindo no cálculo de tal percentual a área de preservação permanente (artigo 32 e $§ 1^{\circ}$, da Lei Geral de Gestão de Florestas Públicas).

A reserva absoluta não pode ser objeto de qualquer tipo de exploração econômica e sua área pode ser definida pelo órgão gestor previamente à elaboração do Plano de Manejo Florestal Sustentável ( $§ 2^{\circ}$ e $3^{\circ}$, do mesmo artigo).

Tecnicamente tal reserva absoluta é uma espécie de amostragem, que assim Eder Zanetti ${ }^{288}$ explica: "Dependendo da variabilidade dos usos da terra ou mesmo das tipologias florestais, o tamanho da amostragem pode também vir a variar, rotineiramente aceitando-se um limite mínimo de $1 \%$ e não necessitando mais de $2,5 \%$ do terreno em virtude dessas variações descritas.".

\footnotetext{
${ }^{287}$ Parcerias na Administração Pública, Concessão, Permissão, Franquia, Terceirização, Parceria PúblicoPrivada e outras formas, São Paulo: Atlas, 2006. p. 129

${ }^{288}$ Certificação e Manejo de Florestas Nativas Brasileiras, Curitiba: Juruá, 2007. p. 141
} 
Da opinião técnica e doutrinária retro transcrita, denota-se que houve uma preocupação até exacerbada na Lei Geral de Gestão de Florestas Públicas em determinar o percentual da reserva absoluta em cinco por cento da área da unidade de manejo concedida, o que, por outro lado, pode garantir maior controle da manutenção da biodiversidade e, em consequiência, sustentabilidade da atividade.

\subsubsection{Prazo da concessão florestal:}

No tópico 5.1, do presente Capítulo, quando da análise do conceito legal de concessão florestal, foi abordada a disciplina jurídica do prazo da concessão florestal, constante no artigo 35, da Lei Geral de Gestão de Florestas Públicas.

Segundo tal dispositivo legal, o prazo da concessão florestal será estabelecido de acordo com o ciclo de colheita ou exploração, considerando o produto ou grupo de produtos com ciclo mais longo incluído no objeto da concessão, podendo ser fixado prazo equivalente a, no mínimo, um ciclo e, no máximo, 40 (quarenta) anos.

Em relação às concessões florestais cujo objeto exclusivo seja a exploração de serviços florestais, o prazo é de, no mínimo, 5 (cinco) e, no máximo, 20 (vinte) anos.

Interessante notar que os prazos de concessão florestal não são curtos, o que está em conformidade com o que tecnicamente se defende, pois Claudio Ferraz e Ronaldo Seroa da Motta ${ }^{289}$ explicam que não são adequados prazos muito curtos para as concessões florestais, pois estimulam o concessionário a tentar maximizar seus lucros pela exploração exagerada de madeira, causando maior dano ambiental.

Tais técnicos exemplificaram com situações negativas ambientalmente ocorridas nas Filipinas, Indonésia, Libéria, Gabão, Sabah e República da África Central, aonde os prazos de concessão são de até vinte anos e outros países, aonde chegam a cinco e dez anos, pois, "a maior parte das florestas tropicais requerem pelo menos de 60 a 100 anos para a sua regeneração parcial”, e assim explicam:

O concessionário tendo em vista um período relativamente curto para explorar a sua área de concessão, agirá de forma racional e tentará maximizar os seus lucros. Dado que ele não se beneficiaria de um processo de regeneração da floresta, ele terá todos os incentivos para cortar o máximo de

289 Concessões Florestais e Exploração Madeireira no Brasil, Condicionantes para a Sustentabilidade, Brasília: Ministério do Meio Ambiente, Programa Nacional de Florestas, 2002, p. 28 
madeira possível dentro do seu período de concessão. Dessa forma, os incentivos dados por um período de concessão muito curto são perversos e vão contra qualquer requerimento mínimo de sustentabilidade. (grifo nosso)

Portanto, é condição para a manutenção da sustentabilidade um prazo contratual mais longo, que não venha a servir de estímulo à destruição da floresta.

Por outro lado, segundo Antonio Benedito de Siqueira ${ }^{290}$, o investimento florestal "implica na demanda de um montante não desprezível de capital, sendo que o dinheiro alocado na atividade fica imobilizado por muito tempo, haja vista que a maturação do negócio é assaz longa", pois existem duas variáveis a ser consideradas, "o montante a ser aplicado e o tempo que fica imobilizado" e conclui que tais variáveis "têm influência decisiva nas expectativas de quem está investindo dinheiro próprio ou emprestado e de quem está concedendo o crédito para financiar o empreendimento florestal”.

As razões técnicas retro expostas demonstram a necessidade de fixação de maiores prazos na concessão florestal, tanto em razão do investimento na atividade, quanto na manutenção da sustentabilidade dos ecossistemas, afastando-se a aplicação do artigo 57, da Lei $n^{\circ}$ 8.666, de 21 de junho de 1993 (Lei Geral de Licitações e Contratos Administrativos).

Maria Sylvia Zanella Di Pietro ${ }^{291}$, ao analisar a questão de prazos mais longos em concessão de uso de bem público, portanto sem considerar a situação específica da concessão florestal, reconheceu a inaplicabilidade de tal dispositivo legal, merecendo transcrição sua lição:

Existem contratos de concessão de uso somente viáveis se o prazo for bastante longo. É o que ocorre nas concessões que exigem instalações onerosas por parte do concessionário, hipótese em que a curta duração do contrato afastaria eventuais interessados, por não permitir a recuperação dos gastos. Por outras palavras, a curta duração é incompatível com os contratos de concessão de uso. (grifo nosso)

Realmente, entende-se que a doutrinadora está repleta de razão, pois o caso específico da concessão florestal amolda-se exatamente à consideração por ela posta, de tratar-se de uma concessão que exige instalações onerosas, entre outros aspectos ressaltados.

\footnotetext{
${ }^{290}$ Produção Florestal Empresarial e Associativa, Análise e Contextualização Macroeconômicas, Curitiba: Juruá, 2009. p. 75

${ }^{291}$ Temas polêmicos sobre Licitações e Contratos, São Paulo: Malheiros Editores, 2000. p. 274
} 
Além disso, Deoclides Ricardo de Souza ${ }^{292}$ anota que as florestas tropicais nativas possuem uma complexidade de ecossistemas que "dificulta as avaliações de parâmetros biológicos, principalmente os relacionados com o crescimento e produção".

Explica, também, que em razão de não se ter ainda uma tradição de estruturas de produção sustentável nessas florestas:

(...) é necessária a fixação do tamanho ótimo de ciclos de corte para atingir uma distribuição diamétrica e uma composição de espécies adequadas aos propósitos do manejo de modo a permitir a regeneração, o crescimento e o desenvolvimento prioritariamente de árvores de valor comercial.

Diante de tal explicação dos motivos técnicos, compreende-se o motivo da Lei Geral de Gestão de Florestas Públicas ter determinado a fixação do prazo da concessão florestal em função do ciclo de corte das espécies, critério este indispensável para a manutenção da sustentabilidade.

\subsubsection{Regime econômico e financeiro da concessão florestal:}

O regime econômico e financeiro de um contrato de concessão de uso de bem público envolve questões como a fixação da contraprestação devida pelo concessionário pelo uso privativo do bem público, de natureza jurídica de preço público, o reajustamento de preço, a taxa de juros na hipótese de atraso no pagamento de tal preço, a fixação de multa moratória, entre outros aspectos.

No caso da concessão florestal, a Lei Geral de Gestão de Florestas Públicas estabeleceu numerosas regras a respeito do assunto, dada a especificidade da atividade de manejo florestal sustentável, podendo ser pinçados os seguintes aspectos:

a) critérios de formação do preço público ("preço florestal");

b) critérios para o reajuste de tal preço público;

c) inadimplemento do preço público pelo concessionário;

d) fixação de salvaguardas de proteção da concorrência;

e) fixação de bônus ao concessionário (desconto no preço público);

f) compromisso de investimento mínimo;

g) garantia de direitos emergentes da concessão em financiamentos.

${ }^{292}$ Ciclo de Corte Econômico Ótimo em Floresta Ombrófila Densa de Terra Firme sob Manejo Florestal Sustentável, Amazônia Oriental, in Revista Árvore, vol. 28, 2004, n ${ }^{\circ}$, Viçosa/MG, p. 681-689 
Para maior didática, tais aspectos são analisados nos subtópicos adiante.

\subsubsection{Formação do preço florestal:}

Primeiramente, o regime econômico e financeiro ao qual o preço florestal está submetido, conforme o artigo 36, incisos I a IV, deve compreender:

a) o pagamento de preço calculado sobre os custos de realização do edital de licitação da concessão florestal da unidade de manejo;

b) o pagamento de preço, não inferior ao mínimo definido no edital de licitação, calculado em função da quantidade de produto ou serviço auferido do objeto da concessão ou do faturamento líquido ou bruto;

c) a responsabilidade do concessionário de realizar outros investimentos previstos no edital e no contrato;

d) a indisponibilidade, pelo concessionário, salvo disposição contratual, dos bens considerados reversíveis.

De forma mais simplificada, pode-se denominar o preço florestal de “preço florestal total”, uma vez que ele é composto pelas seguintes parcelas, fixadas para atender as referidas finalidades do regime econômico financeiro da concessão florestal:

a) parcela remuneratória dos custos da licitação, podendo ser denominada de "preço da licitação";

b) parcela remuneratória do manejo florestal, podendo ser denominada de "preço de manejo";

c) parcela para realização de investimentos, podendo ser denominada de "preço de investimento";

d) parcela indenizatória dos bens reversíveis, podendo ser denominada de "preço de indenização de bens reversíveis", que, na verdade, é um desconto no preço, adiante melhor explicado.

Entendida a composição do "preço florestal total" pelo "preço da licitação", "preço de manejo", "preço de investimento" e "preço de indenização dos bens reversíveis", abordam-se as regras específicas para cada um deles.

Em relação ao "preço da licitação", no artigo $36, \S 1^{\circ}$, da Lei Geral de Gestão de Florestas Públicas é prevista uma regra de que o seu valor deve ser previsto no edital da licitação e pode ser parcelado em até um ano pelo concessionário. 
Conforme já estudado no subtópico 5.4.1.10 do presente trabalho, as regras aplicáveis ao cálculo de tal "preço da licitação" são aquelas constantes no artigo 37, do Regulamento da Lei Geral de Gestão de Florestas Públicas que determinam que seja levado em consideração, basicamente, os valores gastos com a elaboração do inventário florestal, dos estudos preliminares, do relatório ambiental preliminar (RAP), do licenciamento ambiental e da publicação e julgamento das propostas.

Para a segunda parcela do "preço florestal total", o "preço de manejo", aplica-se o previsto no artigo 37, incisos I e II, da Lei Geral de Gestão de Florestas Públicas, que estabelece que compreende seu valor o estabelecido no termo contratual e os valores resultantes da aplicação de critérios de revisão ou de reajuste, nas condições contratuais e definição em ato do órgão gestor, com antecedência mínima de 30 (trinta) dias em relação à data de pagamento (parágrafo único, do mesmo artigo).

Também se aplica à formação do "preço de manejo" o previsto no artigo 39, do Regulamento da Lei Geral de Gestão de Florestas Públicas, que fixa parâmetros que devem ser especificados no edital de licitação e considerar os seguintes aspectos dos produtos e serviços:

a) unidades de medida;

b) critérios de agrupamento de produtos e serviços florestais, que devem permitir a inclusão de novos produtos e serviços $\left(\S 1^{\circ}\right.$, do mesmo artigo); e

c) metodologia de medição e quantificação.

Isto significa que o edital deve definir previamente estes parâmetros, de forma uniforme, para que os licitantes possam ofertar suas propostas de preço florestal.

Para o "preço de investimento", terceira parcela do "preço florestal total", a Lei Geral de Gestão de Florestas Públicas dedicou apenas o artigo 38, prevendo que, no termo contratual da concessão florestal, pode ser previsto um compromisso de investimento mínimo anual, por parte do concessionário, destinado à modernização da execução do Plano de Manejo Florestal Sustentável, visando sua sustentabilidade.

A última parcela do "preço florestal total", referente à indenização dos bens reversíveis, a Lei Geral de Gestão de Florestas Públicas não definiu regras específicas, apenas considerou no artigo 36, inciso IV, possibilidade do termo contratual discipliná-lo.

A reversão no contrato de concessão florestal foi estudada no subtópico 5.4.1.9 deste trabalho, tendo sido demonstrada a necessidade, em regra, de indenização ao 
concessionário pelos bens reversíveis, para que não fique caracterizado um confisco por parte do poder concedente.

Desta forma, a parcela do "preço florestal total" referente à indenização pelos bens reversíveis, caso seja a primeira concessão florestal sobre a área, é um desconto do preço, pois os bens reversíveis são aqueles que o concessionário agregou ao patrimônio público e que, cessada a concessão florestal, permanecem sob o domínio do poder concedente, em razão do princípio da precaução e do desenvolvimento sustentável.

Conforme demonstrado no referido subtópico, se fosse uma concessão de serviço público, o fundamento seria outro, o princípio da continuidade do serviço público.

Dessa forma pensando, reitera-se, para uma primeira concessão florestal de uma área, uma melhor proposta de preço florestal é aquela que contempla um maior desconto na indenização, pela Administração Pública, dos bens reversíveis, em favor do concessionário.

Outra situação é da área em que já tenha ocorrido uma concessão florestal, em que o há equipamentos agregados ao manejo florestal sustentável que eram considerados bens reversíveis na primeira concessão.

Neste caso, adota-se a mesma sistemática das demais parcelas do "preço florestal total", ou seja, o uso de tais bens reversíveis (que a rigor, se incorporados ao patrimônio público, não deveriam assim ser mais denominados) deverá ser remunerado pelo concessionário da mesma forma que o manejo florestal em si.

Analisadas as regras aplicáveis a cada parcela que compõe o preço florestal, indispensável compreender que ele nasce da melhor proposta, apresentada pelo licitante vencedor e que, para qualquer proposta possa ser apresentada é indispensável a existência de um parâmetro mínimo calculado pelo poder concedente e informado no edital.

Em linguagem mais simples, o poder concedente deve calcular um preço florestal mínimo e incluí-lo no edital de licitação para que os interessados possam apresentar suas propostas acima de tal valor.

Em relação à formação desse preço mínimo pela Administração, a Lei Geral de Gestão de Florestas Públicas estabelece em seu artigo 36, §2º que ele deverá considerar:

a) estímulo à competição e à concorrência;

b) garantia de condições de competição do manejo em terras privadas;

c) cobertura dos custos do sistema de outorga; 
d) geração de benefícios para a sociedade, aferidos inclusive pela renda gerada;

e) estímulo ao uso múltiplo da floresta;

f) manutenção e a ampliação da competitividade da atividade de base florestal;

g) referências internacionais aplicáveis.

A esta regra, se soma aquela prevista no artigo $39, \S 2^{\circ}$, do Regulamento da Lei Geral de Gestão de Florestas Públicas, que determina que a definição do preço mínimo possa ser feita a partir de:

a) preços mínimos de cada produto ou serviço;

b) estimativa de arrecadação anual total dos produtos e serviços;

c) combinação do método de unidades de medida e critérios de agrupamento de produtos e serviços florestais, tal como adotado na definição do "preço florestal total", suso analisado.

Além do preço mínimo, que também pode ser denominado de "preço referencial" da licitação para concessão florestal, compete ao poder concedente fixar um valor mínimo de preço florestal que, conforme artigo $36, \S 3^{\circ}$, da Lei de Geral de Gestão de Florestas Públicas, deve ser exigido anualmente independentemente da produção e dos valores auferidos pelo manejo florestal sustentável.

Neste ponto importante ressaltar: não se pode confundir o preço mínimo com o valor mínimo de preço florestal.

O primeiro é calculado pelo poder concedente para servir de parâmetro mínimo para os licitantes apresentarem suas ofertas, ou seja, é um preço referencial da licitação.

O segundo é um valor mínimo, um piso de preço florestal, fixado no termo contratual, para ser pago pelo concessionário, em periodicidade anual, independentemente da produzido pelo manejo florestal.

Pois bem, em relação ao valor mínimo (piso) do preço florestal aplicam-se as seguintes regras, previstas no artigo $36, \S \S 3^{\circ}, 4^{\circ}$ e $5^{\circ}$, da Lei Geral de Gestão de Florestas Públicas:

a) é exigido anualmente do concessionário;

b) independe da produção do manejo florestal;

c) integra os pagamentos anuais do "preço de manejo";

d) a "soma dos valores pagos" não pode ser superior a 30\% (trinta) por cento do "preço de manejo". 
O artigo 40, do Regulamento da Lei Geral de Gestão de Florestas Públicas, esmiúça o cálculo e demais regras aplicáveis ao piso de preço florestal determinando:

a) que deve ser de até trinta por cento do preço anual vencedor do processo licitatório, calculado em função da estimativa de produção fixada no edital e os preços de produtos e serviços contidos na proposta vencedora;

b) o percentual aplicável na definição de tal piso deve ser fixado no edital ( $\S 1^{\circ}$, do citado artigo);

c) o seu valor deve ser fixado e expresso no contrato de concessão em moeda corrente do País, cabendo revisões e reajustes ( $\$ 2^{\circ}$, do citado artigo);

d) o seu pagamento deve ser compensado no "preço de manejo", desde que ocorra no mesmo ano;

e) só exigível após a aprovação do Plano de Manejo Florestal Sustentável pelo IBAMA, salvo quando o atraso em tal aprovação for de responsabilidade do concessionário.

Denota-se que a vagueza do artigo $36, \S 5^{\circ}$, da Lei Geral de Gestão de Florestas Públicas, quanto ao montante sobre o qual o percentual de $30 \%$ (trinta por cento) incidiria foi resolvida com a regra do artigo 40, "caput", que delimitou tratar-se do preço anual vencedor da licitação.

\subsubsection{Reajuste do preço florestal:}

O reajuste dos preços florestais deve ser anual, com base em metodologia a ser definida pelo Serviço Florestal Brasileiro e especificada no edital de licitação e no contrato de concessão, conforme regra do artigo 48, do Regulamento da Lei Geral de Gestão de Florestas Públicas.

Para tal fim, conforme artigo 49, do mesmo Regulamento, o referido órgão gestor desenvolverá e manterá atualizado sistema de acompanhamento dos preços e outros aspectos do mercado de produtos e serviços florestais

\subsubsection{Fixação de bônus:}

No contrato de concessão florestal foi adotada a sistemática de concessão de bônus ao concessionário que atingir parâmetros de desempenho socioambiental, além 
das obrigações legais e contratuais, conforme previsão do artigo 46, da Lei Geral de Gestão de Florestas Públicas.

Tais bônus, em verdade, nada mais são do que descontos no valor do preço florestal pago pelo concessionário, segundo critérios e indicadores de desempenho definidos pelo Serviço Florestal Brasileiro e que devem ser previamente expressos no edital de licitação ( $\$ 1^{\circ}$ e $2^{\circ}$, do referido dispositivo).

Finalmente, segundo o $\S 3^{\underline{0}}$, do mesmo artigo, a aplicação de bônus ou descontos no preço florestal não pode ser maior do que o preço mínimo fixado pelo poder concedente como referencial na licitação, ou seja, o teto do bônus é o preço florestal mínimo adotado pela Administração.

\subsubsection{Inadimplência do preço florestal:}

A hipótese de inadimplemento do preço florestal é tratada somente no artigo 51, do Regulamento da Lei Geral de Gestão Florestal.

Tal dispositivo do ato administrativo normativo determina que, em caso de não pagamento dos preços florestais, o órgão gestor poderá determinar a suspensão do contrato de concessão florestal, até que haja o pagamento do valor mínimo anual ( $\S 1^{\circ}$, do mesmo artigo).

A redação de tal dispositivo legal é criticável, pois confunde uma hipótese de não pagamento do preço florestal com outras hipóteses de descumprimento do contrato de concessão florestal em questões técnicas.

A suspensão das atividades de manejo florestal sustentável, com a finalidade de adequação da conduta do concessionário no respeito às normas técnicas é até justificável, mas, tão somente para a resolução da inadimplência no pagamento do preço florestal, não parece ser a via mais adequada.

Um concessionário inadimplente até mesmo de preço florestal mínimo, fora de hipóteses em que isto é justificável, conforme $\S 1^{\circ}$, do citado artigo 51 , deve ter a concessão florestal declarada rescindida, após devido processo legal, com a aplicação das sanções contratuais cabíveis e posterior levantamento da garantia contratual, além da perda de benfeitorias e bens reversíveis, conforme previsto em contrato.

A suspensão, na hipótese de inadimplência de preços florestais, servirá, em verdade, analisado o comportamento do concessionário na situação concreta, para a promoção do referido processo administrativo. 
Os $\S \S 2^{\underline{o}}$ e $3^{\circ}$, do citado dispositivo regulamentar, prevêem que devem ser indicados, no termo contratual, procedimentos administrativos para solução de divergências na interpretação e na aplicação dos contratos de concessão florestal e solução de conflitos sociais, sob pena de adoção de penalidades.

Mais uma vez merece crítica a redação da norma regulamentar, pois prevê genericamente uma obrigação de resolução de conflitos sociais que em nada relacionam-se com o objeto da concessão florestal.

\subsubsection{5: Salvaguardas da concorrência:}

A Lei Geral de Gestão de Florestas Públicas, em seu artigo 34, denominou de "salvaguardas" as seguintes medidas para evitar a concentração econômica na concessão florestal:

a) em cada lote de concessão florestal, não poderão ser outorgados a cada concessionário, individualmente ou em consórcio, mais de 2 (dois) contratos de concessão florestal;

b) cada concessionário, individualmente ou em consórcio, terá um limite percentual máximo de área de concessão florestal, definido no Plano Anual de Outorga Florestal.

Segundo o parágrafo único, do mesmo dispositivo legal, o referido limite deve ser aplicado sobre o total da área destinada à concessão florestal pelo Plano Anual de Outorga Florestal e pelos planos anuais de outorga em execução aprovados nos anos anteriores.

No artigo 77, da Lei Geral de Gestão de Florestas Públicas é previsto que, ao final dos 10 (dez) primeiros anos, contados da data de publicação da referida Lei, cada concessionário, individualmente ou em consórcio, não poderá concentrar mais de $10 \%$ (dez por cento) do total da área das florestas públicas disponíveis para a concessão em cada esfera de governo.

Ainda sobre tal tema, no artigo 53, incisos XVII, XVIII, XIX e XXI, da Lei Geral de Gestão de Florestas Públicas, são previstas competências dos órgãos gestores das florestas públicas no âmbito federal, estadual e municipal, no seguinte sentido:

a) atuar em cooperação com órgãos de defesa da concorrência, para impedir a concentração econômica nos serviços e produtos florestais e promover a concorrência;

b) acompanhar as práticas de mercado dos agentes do setor florestal, com a finalidade de zelar pelo cumprimento da legislação de defesa da concorrência e incentivar competitividade; 
c) efetuar controle prévio e posterior de atos e negócios jurídicas celebrados entre concessionários, impondo-lhes restrições à mútua constituição de direitos e obrigações, especialmente comerciais, incluindo a abstenção do próprio ato ou contrato ilegal;

d) promover ações de disciplina dos mercados de produtos florestais e derivados, para controlar a competição de produtos florestais de origem não sustentável.

No artigo 45, do Regulamento da Lei Geral de Gestão de Florestas Públicas, é reiterada a regra de competência do Serviço Florestal Brasileiro, no âmbito federal e definida a competência deste para submeter outros aspectos inerentes aos atos e negócios jurídicos a serem celebrados entre concessionários ao Sistema Brasileiro de Defesa da Concorrência, quando necessário.

Percebe-se, pela estruturação da legislação, que houve uma preocupação da União de criar um órgão gestor de florestas públicas com atribuições até mesmo de defesa da concorrência no setor florestal.

A competência, porém, de tal atividade regulatória é do citado Sistema Brasileiro de Defesa da Concorrência, competindo ao órgão gestor de florestas públicas a ele a submissão das questões que julgar tratar-se de defesa da concorrência no setor, respeitados os limites da lei.

\subsubsection{Financiamento garantido por direitos emergentes:}

Os concessionários, nos contratos de financiamento, podem oferecer em garantia direitos emergentes da concessão florestal, até um limite que não comprometa a operacionalização e a continuidade do Plano de Manejo Florestal Sustentável ou das demais atividades florestais, devendo ser tal limite definido pelo órgão gestor das florestas públicas. Estas são as regras do artigo 29, “caput” e seu parágrafo único, da Lei Geral de Gestão de Florestas Públicas.

Tal dispositivo legal é praticamente idêntico ao artigo 28, da Lei $n^{\circ} 8.987$, de 13 de fevereiro de 1995 (Lei de Concessões e Permissões), que mereceu o seguinte comentário de Maria Sylvia Zanella Di Pietro ${ }^{293}$ : “Embora a norma não o diga, é evidente que essa cessão dos créditos futuros não pode ser feita em prejuízo da continuidade do serviço.".

${ }^{293}$ Direito Administrativo, São Paulo: Atlas, 2008. p. 284 
Feitas as devidas adaptações, o mesmo pode ser dito em relação ao dispositivo da Lei Geral de Gestão de Florestas Públicas, ou seja, desde que não haja prejuízo à continuidade da sustentabilidade no manejo florestal, tal cessão de créditos futuros emergentes da concessão florestal, com a finalidade de garantir financiamentos, deverá ser permitida.

\subsubsection{Gestão do contrato de concessão florestal:}

Indispensável ao sucesso da concessão florestal, como em qualquer outro contrato administrativo, uma fiscalização eficiente do cumprimento de suas regras pelo concessionário, ou seja, a gestão pelo poder concedente.

Antonio Carlos Cintra do Amaral ${ }^{294}$, de forma muito completa, resume as atividades componentes da gestão de contratos administrativos ressaltando o planejamento, o controle das obrigações das partes, o controle de providências de cada uma delas, o diligenciamento ("fazer as coisas acontecerem, conduzir o processo"), a informação e a coordenação de interfaces, articulando internamente pessoas e áreas envolvidas na execução do contrato e, finalmente, o registro de tais atividades.

Mesma sistemática deve ser adotada na concessão florestal, uma vez que se trata de um contrato administrativo.

Maria Luiza Machado Granziera ${ }^{295}$, inclusive, entende que o sistema contratual em gestão ambiental "tem a vantagem de ser absolutamente claro e objetivo das condições, obrigações e responsabilidades estabelecidas" e conclui "que o acompanhamento e a fiscalização da execução dos contratos públicos (...) são fatores de efetividade da norma e constituem poder-dever da Administração, em decorrência do princípio da indisponibilidade do interesse público".

Concorda-se com tal opinião e anota-se que, sobre tal temática, a Lei Geral de Gestão de Florestas Públicas regulamenta a atividade de fiscalização do órgão gestor e as auditorias florestais, dois instrumentos indispensáveis à consecução do fim pretendido de se velar pela sustentabilidade do manejo florestal.

Segundo o artigo 42, da Lei Geral de Gestão de Florestas Públicas, sem prejuízo das ações de fiscalização ordinárias, as concessões devem ser submetidas a

${ }^{294}$ Licitação e Contrato Administrativo, Estudos, Pareceres e Comentários, Belo Horizonte: Editora Fórum, 2006. p. 222-223

${ }^{295}$ Mecanismos de efetividade da lei sobre florestas públicas, in Revista de Direito Ambiental, ano 13, n. 49, jan.-mar./2008, p. 201-216. 
auditorias florestais, de caráter independente, em prazos não superiores a 3 (três) anos, cujos custos são de responsabilidade do concessionário.

Admite, porém, uma exceção à regra do prazo de três anos, para os casos previstos no edital de licitação nos quais a escala da atividade florestal torne inviável o pagamento dos custos de tais auditorias florestais pelo concessionário.

As auditorias florestais, conforme o $\$ 2^{\circ}$, do mesmo artigo, devem constatar o regular cumprimento do contrato de concessão, a existência de deficiências sanáveis, que devem ser saneadas no prazo máximo de 6 (seis) meses e o descumprimento do contrato, que, devidamente validado pelo órgão gestor, implica a aplicação de sanções segundo sua gravidade e até a rescisão contratual.

As auditorias florestais, por seu turno, devem ser previamente reconhecidas em ato administrativo do órgão gestor.

O artigo 55, do Regulamento da Lei Geral de Gestão de Florestas Públicas, estabelece que o órgão gestor federal deve definir os critérios, indicadores, conteúdo, prazos e condições para a realização e a forma de garantir a publicidade das auditorias florestais, realizadas em florestas públicas federais.

Quanto à formação de um sistema de acreditação de entidades públicas ou privadas de auditorias florestais, a definição de critérios mínimos de auditoria, a criação de modelos de relatórios das auditorias florestais e fixação de prazos para a entrega de relatórios, o artigo 57, do referido Regulamento, atribuiu tal competência ao Instituto Nacional de Metrologia, Normalização e Qualidade Industrial - INMETRO, o que foi reiterado no artigo 58, apenas acrescentando-se que, obrigatoriamente, deverão ocorrer verificações em campo e consultas à comunidade e autoridades locais.

Para viabilizar as auditorias em pequenas unidades de manejo, o artigo 59, do Regulamento da Lei Geral de Gestão de Florestas Públicas, previu a possibilidade do Serviço Florestal Brasileiro adotar auditorias em grupo, procedimentos simplificados definidos pelo INMETRO e desconto no preço dos recursos florestais auferidos da floresta pública.

O mesmo Regulamento, em seu artigo 52, considera que o monitoramento das florestas públicas federais deve ater-ser, no mínimo, aos aspectos de verificação da implementação do Plano de Manejo Florestal Sustentável, na proteção de espécies endêmicas e ameaçadas de extinção, dos corpos d'água, da floresta contra incêndios, desmatamentos, explorações ilegais e outras ameaças, a dinâmica de desenvolvimento da floresta. 
Neste monitoramento, também devem ser considerados aspectos sociais, tais como as condições de trabalho, existência de conflitos socioambientais, impactos sociais, ambientais, econômicos e outros que possam afetar a segurança pública e a defesa nacional, e aspectos econômicos, tal como a qualidade da indústria de beneficiamento primário, além do cumprimento em si do contrato de concessão florestal.

O Serviço Florestal Brasileiro, no monitoramento das florestas públicas, deve articular com outros órgãos e entidades responsáveis pelo planejamento, gestão e execução dos sistemas de monitoramento, controle e fiscalização, e expedirá o Relatório Anual de Gestão de Florestas Públicas da União, que pode, inclusive, ser debatido em audiências públicas, conforme prevêem os artigos 53 e 54, do citado Regulamento da Lei Geral de Gestão de Florestas Públicas.

O órgão gestor das florestas públicas federais, por conta do artigo 55, do mesmo Regulamento, é obrigado a disponibilizar na rede mundial de computadores dispositivos para acesso aos sistemas usados no monitoramento da gestão de florestas públicas federais.

Com isso, mais uma demonstração de que o princípio da participação, previsto no artigo 225, "caput", da Constituição Federal, foi prestigiado também neste aspecto da gestão de florestas públicas.

No artigo 43, da Lei Geral de Gestão de Florestas Públicas, foi conferido o direito a qualquer pessoa física ou jurídica, de forma justificada e devidamente assistida por profissionais habilitados, de fazer visitas de comprovação às operações florestais de campo, desde que não obstando o regular desenvolvimento das atividades, devendo tal visita ser previamente autorizada e programada pelo órgão gestor.

$\mathrm{Na}$ gestão do contrato de concessão florestal, vislumbra-se, ainda, a possibilidade do estabelecimento de convênios ou outros tipos de parceria com organizações do terceiro setor, tais com organizações da sociedade civil de interesse público, associações entre outras, pelo poder concedente, em modelo similar àquele adotado na gestão de unidades de conservação, previsto no artigo 30, da Lei $n^{\circ}$ 9.985, de 18 de julho de 2000 (Lei do Sistema Nacional de Unidades de Conservação).

\subsubsection{Extinção da concessão florestal:}

O artigo 44, da Lei Geral de Gestão de Florestas Públicas, prevê como hipóteses de extinção da concessão florestal as seguintes causas: 
a) esgotamento do prazo contratual;

b) rescisão;

c) anulação;

d) falência ou extinção do concessionário e falecimento ou incapacidade do titular, no caso de empresa individual;

e) desistência e devolução, por opção do concessionário, do objeto da concessão.

Os efeitos da extinção da concessão florestal, previstos nos $\S \S 1^{\circ}$ a $5^{\circ}$, da citada Lei, são os seguintes:

a) retorno ao titular da floresta pública de todos os bens reversíveis, direitos e privilégios transferidos ao concessionário, conforme previsto no edital e estabelecido em contrato;

b) ocupação das instalações e utilização, pelo titular da floresta pública, de todos os bens reversíveis, independentemente de notificação prévia;

c) nas hipóteses de rescisão, falência ou extinção do concessionário, falecimento ou incapacidade do titular e desistência ou devolução do objeto da concessão, por opção do concessionário, o poder concedente fica autorizado a executar as garantias contratuais, sem prejuízo da responsabilidade civil por danos ambientais prevista na Lei no 6.983 , de 31 de agosto de 1981 (Lei da Política Nacional do Meio Ambiente);

d) na hipótese de desistência e devolução de áreas, a inexistência de qualquer ônus ao poder concedente e inexistência de qualquer direito de indenização pelos bens reversíveis ao concessionário, devendo tais bens passar ao domínio do poder concedente;

e) em qualquer das hipóteses, deve o concessionário, por conta e risco exclusivos, remover os equipamentos e bens que não sejam objetos de reversão, ficando obrigado a reparar ou indenizar os danos decorrentes de suas atividades e praticar os atos de recuperação ambiental determinados pelos órgãos competentes.

Além de tais efeitos específicos, a inexecução total ou parcial do contrato, a critério do poder concedente, acarreta a rescisão da concessão florestal com a aplicação das sanções contratuais, execução das garantias e promoção da responsabilidade civil por danos ambientais prevista na Lei da Política Nacional do Meio Ambiente, além das sanções nas esferas administrativa e penal, conforme artigo 45, "caput", da Lei Geral de Gestão de Florestas Públicas.

A expressão "a critério do poder concedente" expressa discricionariedade, merecendo interpretação, pois tal poder alcança a decisão quanto a proceder-se ou não a rescisão do contrato, a aplicação ou não de sanções e execução de garantias, desde que resguardado o interesse público, no caso sócio-ambiental. 
Também, a responsabilidade ambiental deve ser levada em consideração, uma vez que não há margem de discricionariedade em sua apreciação, sendo esta a opinião também de Toshio Mukai ${ }^{296}$ : "Quanto a exercer o direito à responsabilização ambiental e a aplicar as sanções administrativas e penais, entendemos que aí não há discricionariedade do poder concedente. A efetivação dessas providências é obrigatória." (grifo nosso).

As hipóteses em que é cabível a rescisão unilateral da concessão florestal, pelo poder concedente, são aquelas do $\S 1^{\circ}$, incisos I a X, do mesmo artigo, e ocorrem quando o concessionário:

a) descumprir as cláusulas contratuais ou disposições legais e regulamentares concernentes à concessão;

b) descumprir o Plano de Manejo Florestal Sustentável, de forma que afete elementos essenciais de proteção do meio ambiente e a sustentabilidade da atividade;

c) paralisar a execução do referido plano, por prazo superior ao previsto no contrato, ressalvadas as hipóteses decorrentes de caso fortuito ou força maior, ou as que, com anuência do órgão gestor, visem à proteção ambiental;

d) descumprir, total ou parcial, da obrigação de pagamento dos preços florestais;

e) perder as condições econômicas, técnicas ou operacionais para manter a regular execução do Plano de Manejo Florestal Sustentável;

f) não cumprir as penalidades impostas por infrações, nos devidos prazos;

g) não atender a notificação do órgão gestor no sentido de regularizar o exercício de suas atividades;

h) for condenado em sentença transitada em julgado por crime contra o meio ambiente ou a ordem tributária, ou por crime previdenciário;

i) ocorrer fato superveniente de relevante interesse público que justifique a rescisão, mediante lei autorizativa específica, com indenização das parcelas de investimento ainda não amortizadas vinculadas aos bens reversíveis que tenham sido realizados;

h) o concessionário submeter trabalhadores a condições degradantes de trabalho ou análogas à de escravo ou explorar o trabalho de crianças e adolescentes.

$\mathrm{Na}$ hipótese de rescisão do contrato de concessão florestal, deve ser precedida de processo administrativo, assegurado o direito de ampla defesa, para comprovação da inadimplência por parte do concessionário ( $\left(2^{\circ}\right.$, do citado artigo).

\footnotetext{
296 Os Contratos de Concessões Florestais, in Boletim de Licitações e Contratos, Editora NDJ Ltda., Ano
} XIX, n 10 , out. 2006. 
Porém, a instauração do referido processo administrativo só pode ocorrer após o escoamento de prazo concedido ao concessionário florestal para corrigir as falhas e transgressões verificadas, em notificação pelo poder concedente $\left(\$ 3^{\circ}\right.$, do citado artigo).

A promoção de processo administrativo, com ampla defesa ao contratado, é disposição também do artigo 78, parágrafo único, da Lei no 8.666, de 21 de junho de 1993 (Lei Geral de Licitações e Contratos Administrativos), possuindo caráter geral para toda e qualquer decisão da Administração Pública que atinja o patrimônio jurídico do particular e a possibilidade do contratado corrigir as falhas, antes da rescisão do contrato, também tem sua fonte no artigo 69, da mesma Lei.

Neste ponto, portanto, a Lei Geral de Gestão de Florestas Públicas não inovou.

Conforme $\S \S 4^{\circ}$ e $5^{\circ}$, do mencionado dispositivo legal da Lei Geral de Gestão de Florestas Públicas, após a conclusão do processo administrativo, o poder concedente declara rescindida a concessão florestal e, além das sanções contratuais, o concessionário responde nas esferas administrativa, civil e penal, não resultando ao poder concedente ou ao órgão gestor qualquer responsabilidade em relação aos encargos, ônus, obrigações ou compromissos com terceiros ou com empregados do concessionário.

No artigo 45, § $6^{\circ}$, da Lei Geral de Gestão de Florestas Públicas, é conferida ao poder público a possibilidade de instituir seguro para cobertura da indenização das parcelas de investimento ainda não amortizadas vinculadas aos bens reversíveis realizados, quando a extinção da concessão florestal se der em razão da ocorrência de fato superveniente de relevante interesse público.

A hipótese de desistência e devolução do objeto da concessão, conforme conceitua o artigo 46, "caput", da Lei Geral de Gestão de Florestas Públicas, é um ato formal, irrevogável e irretratável pelo qual o concessionário manifesta o desinteresse pela continuidade da concessão florestal, devendo ser aceita, de forma expressa, pelo poder concedente para que se concretize.

Além disso, a referida aceitação expressa do poder concedente é condicionada a uma avaliação prévia, pelo órgão competente, determinante do cumprimento ou não do Plano de Manejo Florestal Sustentável, conforme $\S 1^{\circ}$, do citado artigo.

E, nos termos dos $\S \S 1^{\circ}$ e $2^{\circ}$, do mesmo artigo, o concessionário desistente deve arcar com o custo da referida avaliação prévia e, conforme o caso, com as obrigações emergentes, além de não ficar desonerado de suas obrigações com terceiros. 
Interessante notar que a Lei Geral de Gestão de Florestas Públicas, neste particular inovou, pois previu uma forma de rescisão do contrato de concessão amigável, o que não se encontra nas demais leis que disciplinam as outras espécies de concessão.

Maria Sylvia Zanella Di Pietro ${ }^{297}$, porém, antecipando-se à nova disciplina legal, ao comentar as modalidades de extinção da concessão de serviço público, previstas na Lei $\mathrm{n}^{\circ}$ 8.987, de 13 de fevereiro de 1995 (Lei de Concessões e Permissões), cogitou a hipótese de rescisão amigável, nos seguintes termos:

A lei não faz referência expressa à rescisão amigável, o que pode levar ao entendimento de que ela não é possível na concessão; temem-se os conluios contrários ao interesse público. Contra esse entendimento, podem ser opostos os seguintes argumentos: o art. 35, inciso IV, fala em rescisão, sem fazer qualquer distinção quanto à modalidade; $o$ art. 23, ao indicar as cláusulas essenciais do contrato, inclui, no inciso $\mathrm{XV}$, a pertinente ao "foro e ao modo amigável de solução das divergências contratuais". Além disso, se o concessionário não quiser dar continuidade ao contrato, por razões aceitáveis, e isto não trouxer prejuízos maiores para o interesse público, não há por que esperar que ele vá a juízo e sobrecarregue a Administração com o ônus de uma demanda judicial. (negrito do original, grifo nosso)

Tendo em vista a opinião doutrinária, com a qual se concorda integralmente, a Lei Geral de Gestão de Florestas Públicas contribuiu para melhor racionalização na extinção do contrato, na medida em que, desde que não ocasione prejuízo ao manejo florestal sustentável, a referida rescisão amigável por desistência e devolução da unidade de manejo poderá configurar a melhor solução.

Ou seja, o interesse público neste caso não reside na continuidade de um serviço público, mas na continuidade de uma atividade sustentável de exploração da natureza.

Finalmente, prevê o artigo 47, da Lei Geral de Gestão de Florestas Públicas, que para o contrato de concessão florestal ser rescindido por iniciativa do concessionário, no caso de descumprimento das normas contratuais pelo poder concedente, deverá aquele promover ação judicial especialmente para esse fim.

Rafael Véras de Freitas ${ }^{298}$ critica tal dispositivo legal, sob o argumento de que a concessão florestal seria "contrato situado no âmbito do direito econômico - fora do âmbito do 'jus imperi' Estatal" e propõe uma revisão, "dentro do citado contexto da

${ }^{297}$ Parcerias na Administração Pública, Concessão, Permissão, Franquia, Terceirização, Parceria PúblicoPrivada e outras Formas, São Paulo: Atlas, 2006. p. 133

${ }^{298}$ Loc. cit. 
processualização do direito administrativo", podendo o concessionário florestal ingressar com pedido de rescisão administrativa que obrigue o Poder Público se pronunciar, sob pena de mandado de segurança na hipótese de omissão.

Com o devido respeito ao entendimento doutrinário, o fundamento da regra impositiva de ajuizamento de ação judicial em caso de rescisão motivada por ato do poder concedente, visa garantir a observância do princípio da indisponibilidade do interesse público.

Como a extinção da concessão florestal motivada pelo descumprimento contratual do poder concedente fatalmente gera direito à indenização ao particular, sendo esta, geralmente, de grande monta, não se vislumbra uma possibilidade da própria Administração Pública transigir sobre a rescisão e conseqüente montante de indenização, a não ser em ação judicial específica para tal fim.

As hipóteses em que o poder público assume sua responsabilidade civil ou mesmo extracontratual, são restritas às indenizações com determinado patamar, em processo administrativo simplificado, não se amoldando a esta hipótese a extinção de uma vultosa concessão florestal.

Por isso, e para se assegurar maior certeza do controle externo dos atos da Administração, entende-se que não é desacertada a regra da Lei Geral de Gestão de Florestas Públicas que impõe ao particular a obrigação de ajuizamento de ação judicial para extinguir a concessão florestal motivada por descumprimento contratual por parte do poder concedente.

\subsection{Fundo e repartição de receitas:}

A Lei Geral de Gestão de Florestas Públicas, além de criar as normas específicas da licitação e do contrato, instituir o órgão gestor de floretas públicas federais, também criou um fundo e dispôs sobre a repartição das receitas provenientes da concessão florestal.

\subsubsection{Repartição de receitas da concessão florestal:}

A repartição das receitas da concessão florestal, prevista no artigo 39, da Lei Geral de Gestão de Florestas Públicas, utiliza dois critérios de divisão combinados: o primeiro é o valor mínimo de preço florestal (piso), que deve ser de até 30\% (trinta por 
cento) do valor do "preço florestal total", e o segundo é o fato da concessão florestal ter por objeto áreas dentro ou fora de florestas nacionais.

Assim, para as áreas sob domínio da União, submetidas à concessão florestal, localizadas fora dos limites da floresta nacional:

a) sobre o valor mínimo de preço florestal:

- 70\% (setenta por cento) ao Serviço Florestal Brasileiro;

- 30\% (trinta por cento) ao Instituto Brasileiro do Meio Ambiente e dos Recursos Naturais Renováveis - IBAMA;

b) sobre o valor restante (o que sobra após a retirada do citado valor mínimo):

- 30\% (trinta por cento) aos Estados, nos quais se localizem os lotes de concessão florestal;

- 30\% (trinta por cento) aos Municípios, onde também se localizem tais lotes;

- 40\% (quarenta por cento) ao Fundo Nacional de Desenvolvimento Florestal - FNDF.

Para as áreas sob domínio da União, submetidas à concessão florestal, só que localizadas no interior dos limites da floresta nacional:

a) o valor mínimo é direcionado integralmente ao Serviço Florestal Brasileiro;

b) sobre o valor restante:

- 40\% (quarenta por cento) ao Instituto Chico Mendes de Conservação da Biodiversidade;

- 20\% (vinte por cento) aos Estados em que se localizam os lotes de concessão;

- 20\% (vinte por cento) aos Municípios, onde se localizam os citados lotes também;

- 20\% (vinte por cento) ao Fundo Nacional de Desenvolvimento Florestal - FNDF.

Os Estados e Municípios somente fazem jus ao repasse, com periodicidade trimestral, se possuírem conselhos de meio ambiente, com participação social, sendo tais conselhos competentes para aprovar o cumprimento de metas para a aplicação dos recursos provenientes da referida repartição de receitas da concessão florestal no ano anterior e programar a aplicação de tais recursos no ano em curso (artigo 39, $\$ 3^{\circ}$ combinado com o artigo 40, todos da Lei Geral de Gestão de Florestas Públicas).

\subsubsection{Fundo Nacional de Desenvolvimento Florestal - FNDF:}

No artigo 41, da Lei Geral de Gestão de Florestas Públicas, foi criado o Fundo Nacional de Desenvolvimento Florestal - FNDF, de natureza contábil, gerido pelo Serviço Florestal Brasileiro e destinado a fomentar o desenvolvimento de atividades sustentáveis de base florestal no Brasil e a promover a inovação tecnológica do setor. 
As atividades para as quais os recursos do referido fundo serão aplicados são as seguintes:

a) pesquisa e desenvolvimento tecnológico em manejo florestal;

b) assistência técnica e extensão florestal;

c) recuperação de áreas degradadas com espécies nativas;

d) aproveitamento econômico racional e sustentável dos recursos florestais;

e) controle e monitoramento das atividades florestais e desmatamentos;

f) capacitação em manejo florestal e formação de agentes multiplicadores em atividades florestais;

g) educação ambiental;

h) proteção ao meio ambiente e conservação dos recursos naturais.

$\mathrm{Na}$ gestão do referido fundo deve existir um conselho consultivo, composto por representantes dos entes federativos e da sociedade civil, cuja função é de opinar sobre a distribuição dos seus recursos e a avaliação de sua aplicação.

Constituem receitas do referido FNDF:

a) as receitas provenientes da concessão florestal de áreas localizadas fora e dentro de floresta nacional;

b) a reversão dos saldos anuais não aplicados;

c) doações realizadas por entidades nacionais ou internacionais, públicas ou privadas;

d) orçamentos compartilhados com outros entes da Federação;

e) outras fontes de recursos que lhe forem especificamente destinadas.

É vedada a prestação de garantias pelo FNDF e os seus recursos devem ser aplicados conforme um plano anual regionalizado, podendo ser destinados a projetos de órgãos, entidades públicas e entidades privadas sem fins lucrativos, devendo, porém, ser prioritariamente a entidades públicas de pesquisa ( $\S 5^{\circ}$ a $8^{\circ}$, do citado artigo).

Finalmente, poderão ser beneficiárias dos projetos financiados por recursos do FNDF as comunidades indígenas, comunidades locais e outros $\left(\S 9^{\underline{0}}\right.$, do mesmo artigo).

Interessante notar que estas regras do atual direito positivo brasileiro, possuem muita similaridade com as regras que disciplinavam o primeiro fundo florestal na França, conforme relato de Osny Duarte Pereira em sua clássica obra. 
Em 1950, Osny Duarte Pereira ${ }^{299}$ explicou que o Fundo Florestal Nacional foi criado em 30 de setembro de 1946, na França, composto por financiamento decorrente de "taxa sobre os produtos das serrarias e outros da exploração florestal, exceto os destinados a combustíveis", portanto tributo cobrado especificamente sobre a atividade de exploração florestal.

Entre as finalidades de tal antigo fundo francês, que inspirou a criação de tantos outros pelo mundo, incluía-se a de recomposição de florestas metropolitanas, criação de melhor infra-estrutura para a atividade de exploração florestal e, curiosamente, a manutenção da indivisibilidade de uma floresta em caso de morte e sucessão, pois, naquela época, poderia haver fragmentação da floresta, em porções cada vez menores, após a morte de seu proprietário e a sua sucessão. Este fundo, então, sub-rogava em dinheiro os herdeiros que não herdassem a floresta, mantendo-a indivisível perante apenas um herdeiro.

Além dessas atribuições, o Fundo Florestal Nacional francês também oferecia subvenções e financiamento aos proprietários e exploradores da floresta.

Guardadas as devidas diferenças de espaço e tempo, o importante é verificar que a essência da idéia de constituição de um fundo gerido pelo poder público, para fomento da recuperação e exploração florestal, que na atualidade deve ser obrigatoriamente sustentável, foi adotada na Lei Geral de Gestão de Florestas Públicas.

${ }^{299}$ Direito Florestal Brasileiro - Ensaio, Rio de Janeiro: Editor Borsoi, 1950. p. 35-37 


\section{CONCLUSÃO}

No limiar do presente estudo foi-se no encalço da demonstração, da forma mais completa possível, do conjunto de regras jurídicas que tutelam a flora brasileira, em especial a Lei $\mathrm{n}^{\circ}$ 4.771, de 15 de setembro de 1965 (Código Florestal) e a Lei nº 9.985, de 18 de julho de 2000 (Lei do Sistema Nacional de Unidades de Conservação).

Após a análise dos instrumentos de proteção do patrimônio florestal, certificou-se que a Lei $n^{\circ}$ 11.284, de 02 de março de 2006 (Lei Geral de Gestão de Florestas Públicas) veio para se somar às duas outras leis, formando o tripé básico da aludida proteção florística, sobre o qual são erigidas as demais normas.

Tal disciplina da gestão de florestas públicas veio em boa hora, pois tal candente assunto se encontrava num vácuo normativo, uma vez que o último diploma legal que o disciplinava era o antigo Código Florestal, Decreto $n^{\circ} 23.793$, de 23 de janeiro de 1934, sob a forma do vetusto instituto das florestas de rendimento, numa concepção de exploração econômica da floresta que em nada guardava parecença com o hodierno uso múltiplo, forma de exploração sustentável, defendida, inclusive, por ampla principiologia internacional.

Do conhecimento dos principais instrumentos, reconheceu-se que as florestas públicas e a exploração sustentável, regradas pela nova lei, constituem efetivamente nova forma de proteção da flora e que o contrato pelo qual se desenvolve tal atividade, a concessão florestal, é uma subespécie de concessão de uso de bem público.

Da comparação da concessão florestal com a concessão de serviço público revelou-se que a primeira adotou uma série de institutos jurídicos próprios da segunda, institutos estes que, curiosamente, foram criados na origem para dar sustentação a melhor execução do serviço público, no interesse dos usuários e do poder concedente.

Apesar da utilização dos citados instrumentos próprios da concessão de serviço público, a concessão florestal se mantém como subespécie de concessão de uso de bem público porque a atividade que compõe seu objeto, o manejo florestal sustentável, não é voltada à satisfação de necessidades coletivas diretamente, em outras palavras, não é um serviço público.

Tanto não o é, por exemplo, que na concessão florestal não existe a figura de um usuário da atividade desempenhada pelo concessionário e não há, em consequiência, remuneração ao concessionário por tarifa. 
As obrigações da concessão florestal, ao contrário, decorrem de uma relação jurídica cujo objeto é o uso privativo da floresta pública, desenvolvido de uma determinada forma especialíssima que visa atender requisitos técnicos à sustentabilidade.

Tal forma especial de uso privativo do bem público floresta, nada mais é do que o manejo florestal sustentável, que deve ser antecedido de uma série de outras atividades igualmente complexas sob o ponto de vista técnico, tais como a estruturação de um plano de manejo e a condução de licenciamento ambiental.

Entretanto, conforme dito, a série de institutos próprios da concessão de serviço públicos que foi incorporada nas normas regentes da concessão florestal, assim não o foram em razão do princípio da continuidade do serviço público, mas para dar continuidade à atividade econômica e sócio-ambiental sustentável.

Ou seja, se instrumentos como reversão, encampação, caducidade, com os poderes a eles inerentes exercitáveis pelo poder concedente, foram adotados para a concessão florestal não em razão do princípio da continuidade do serviço público, mas, sim, para atender o princípio da precaução e o princípio do desenvolvimento sustentável, basilares do meio ambiente protegido consagrado no artigo 225, da Constituição Federal.

Quanto às experiências estrangeiras de gestão de florestas públicas e a existência de princípios internacionais de gestão de florestas para produção sustentável, demonstrou-se que a Lei Geral de Florestas Públicas contemplou em seu bojo influências de tais experiências e a quase totalidade desses princípios.

Adentrando-se nas normas jurídicas disciplinadoras da licitação para concessão florestal, descortinou-se que algumas regras gerais de licitações foram aperfeiçoadas, com a finalidade de adaptação do procedimento administrativo ao objeto especial, a atividade de manejo florestal sustentável.

A possibilidade de participação de pessoas jurídicas consorciadas, a obrigatoriedade de constituição de sociedade de propósito específico, a criação de prerrogativas às microempresas e empresas de pequeno porte, a vedação da subconcessão, as especificidades nos critérios de julgamento e na formação do preço florestal, são exemplos de temas que foram aperfeiçoados na licitação para concessão florestal, de tal forma a possibilitar maior eficiência e adequação no procedimento.

Em relação ao contrato administrativo de concessão florestal, também se verificou semelhante melhoramento, por exemplo, em temas como o regime econômicofinanceiro do contrato, a criação de salvaguardas da concorrência, a inovação quanto ao sistema de bonificação do concessionário que atingir determinados patamares de 
desenvolvimento sócio-ambiental, o financiamento garantido por direitos emergentes, a possibilidade de extinção amigável da concessão por meio de desistência e devolução da unidade de manejo pelo concessionário florestal, entre outros.

Aliado a isso tudo, não foram esquecidas de melhoramento as outras formas de gestão da floresta pública, com especial atenção àquelas em que se garantiu às comunidades locais oportunidade de dar continuidade ao seu peculiar modo de vida sustentável na floresta, constituindo a lei uma série de alternativas de desenvolvimento econômico e social a tais comunidades.

Diante de tal quadro, não é difícil se vislumbrar a construção de outros arranjos na gestão das florestas públicas, com a participação de organizações não governamentais, além do poder público, no estabelecimento de parcerias para desenvolver a concessão florestal, principalmente em suas estruturas de governança, auditoria e certificação.

A concessão florestal, desse modo, demonstra ser fruto de uma pensada política pública de gestão de um recurso natural de enorme dimensão e importância estratégica para o país, cuja eficiência e eficácia dependem da profunda reorganização do poder público para promover uma gestão racional do patrimônio público ambiental que garanta a reversão dos frutos econômicos e sócio-ambientais de tal forma sustentável de exploração do patrimônio nacional em benefício da Humanidade.

A Lei Geral de Gestão de Florestas Públicas já plantou as estacas para que esse almejado fim se torne realidade.

E, nesse ponto, o objeto dessa concessão de uso de bem público especialíssima, o uso sustentável da floresta pública, uma vez mais rouba um elemento próprio do serviço público, pois não existe necessidade mais básica de todo ser humano que mereça o adequado atendimento pelo Estado do que viver num meio ambiente ecologicamente equilibrado. 


\section{BIBLIOGRAFIA}

AMADOR, Ana Lúcia das Graças. et al. Roteiro Metodológico para Metodológico para Elaboração de Plano de Manejo para Florestas Nacionais, Brasília: IBAMA, 2003.

AMARAL, Antônio Carlos Cintra do. Licitação e Contrato Administrativo, Estudos, Pareceres e Comentários, Belo Horizonte: Editora Fórum, 2006.

AMARAL, Diogo Freitas do. Curso de Direito Administrativo, Coimbra: Almedina, 2001.

ANTUNES, Paulo de Bessa. Direito Ambiental, Rio de Janeiro: Editora Lumen Juris, 1999.

ARAÚJO, Edmir Netto de. Curso de Direito Administrativo. São Paulo: Saraiva, 2005.

ARAUJO, Gisele Ferreira de. Estratégias de Sustentabilidade na Amazônia: aspectos científicos, sociais e legais, contexto global, visão comparativa. São Paulo: Editora Letras Jurídicas, 2008.

BANDEIRA DE MELLO, Oswaldo. Princípios Gerais de Direito Administrativo, Rio de Janeiro: Editora Forense, 1969.

BARROS, Wellington Pacheco. Curso de Direito Ambiental, $2^{\mathrm{a}}$ ed., São Paulo: Atlas, 2008.

BENATTI, José Heder. Posse Agroecológica \& Manejo Florestal à luz da Lei 9.985/00, Curitiba: Juruá, 2008.

BENJAMIN, Antônio Herman de Vasconcellos e. Os princípios do estudo de impacto ambiental como limites da discricionariedade administrativa, Revista Forense, $\mathrm{n}^{\mathbf{o}} 317$, jan./mar., 1992, Rio de Janeiro. p. 25-45 
Reflexões sobre a Hipertrofia do Direito de Propriedade na Tutela da Reserva Legal e das Áreas de Preservação Permanente. Anais do Congresso Internacional de Direito Ambiental, 5 anos após a ECO-92, São Paulo, 1997.

Desapropriação, Reserva Florestal Legal e Áreas de Preservação Permanente, in Temas de Direito Ambiental e Urbanístico, São Paulo: Max Limonad, 1998, ano II, nº 03, p. $62-79$

, Introdução ao Direito Ambiental Brasileiro, in Anais do $3^{o}$ Congresso Internacional de Direito Ambiental, 30 de maio a 02 de junho de 1999: a proteção jurídica das florestas tropicais, organizado por Antônio Hermann de Vasconcelos e Benjamin, São Paulo: IMESP, 1999. p. 75-113

CAVEDON, Fernanda de Salles, VIEIRA, Ricardo Stanziola, DIEHL, Francelise Pantoja, Regime Jurídico das Áreas de Preservação Permanente e Desenvolvimento Econômico. Conciliação ou Flexibilização? in Revista de Direitos Difusos, Meio Ambiente, Saúde e Desenvolvimento Econômico I, São Paulo, ano VIII, vol. 43, jul-set. 2007, p. 15-37

CENTOFANTI, Nicola. I Beni Publici: Tutela Amministrativa e Giurisdizionale, Milão: Giuffrè, 2007.

CRETELla JUNIOR, José. Tratado do Domínio Público, Rio de Janeiro: Forense, 1984. , Dos Contratos Administrativos, Rio de Janeiro: Editora Forense, 2001.

CUTANDA, Blanca Lozano. Derecho Ambiental Administrativo, Madrid: Dykinson, 2003.

DALLARI, Adilson Abreu. FIGUEIREDO, Lucia Valle, Temas de Direito Urbanístico, São Paulo: RT, 1987.

DEBONI, Giuliano. Florestas: Competência para Legislar e Fiscalizar, Revista Magister de Direito Ambiental e Urbanístico, ano III, n. 14, out.-nov./2007, p. 81-101 
DELGADO, José Augusto. A proteção jurídica das florestas tropicais e a ação de desapropriação indireta. Doutrina e jurisprudência, in Anais do $3^{\circ}$ Congresso Internacional de Direito Ambiental, 30 de maio a 02 de junho de 1999: a proteção jurídica das florestas tropicais, organizado por Antônio Hermann de Vasconcelos e Benjamin, São Paulo: IMESP, 1999, p. 245-278

DERANI, Cristiane. Patrimônio genético e conhecimento tradicional associado: considerações jurídicas sobre seu acesso. In: LIMA, André. O Direito para o Brasil Socioambiental, Porto Alegre: Fabris Editores, 2002.

DEUS, Teresa Cristina de. Tutela da flora em face do direito ambiental brasileiro, São Paulo: Juarez de Oliveira, 2003.

DI PIETRO, Maria Sylvia Zanella. Uso privativo de bem público por particular, São Paulo: Revista dos Tribunais, 1983.

Polícia do meio ambiente, Revista Forense, vol. 317, Rio de Janeiro: Forense, 1992, p. 179-187

, et al. Temas polêmicos sobre Licitações e Contratos, São Paulo: Malheiros Editores, 2000.

, Parcerias na Administração Pública, Concessão, Permissão, Franquia, Terceirização, Parceria Público-Privada e outras formas, São Paulo: Atlas, 2006.

Direito Administrativo, São Paulo: Saraiva, $21^{\mathrm{a}}$ ed., 2008.

DIAS, Edna Cardozo. Gestão de florestas públicas. Biblioteca Digital Fórum de Direito Urbano e Ambiental - FDUA, Belo Horizonte, ano 5, n. 29, set./out. 2006. Disponível em:<http://www.editoraforum.com.br/bid/bidConteudoShow.aspx?idConteudo=37937>. Acesso em: 16 julho 2009.

DROMI, Jose Roberto. Licitación Pública, Buenos Aires: Ediciones Ciudad Argentina, 1995. 
FARIA, Eliana Goulart Leão de. O Código Florestal brasileiro e seu aperfeiçoamento, in DALLARI, Adilson Abreu. FIGUEIREDO, Lucia Valle, Temas de Direito Urbanístico, São Paulo: RT, 1987, p. 74-106.

FERRAZ, Claudio. SEROA DA MOTTA, Ronaldo. Concessões Florestais e Exploração Madeireira no Brasil, Condicionantes para a Sustentabilidade, Brasília: Ministério do Meio Ambiente, Programa Nacional de Florestas, 2002.

FIGUEIREDO, Guilherme José Purvin de. (org.) Temas de Direito Ambiental $e$ Urbanístico, São Paulo: Max Limonad, 1998.

FIORILlO, Celso Antonio Pacheco. Curso de Direito Ambiental Brasileiro, 9a ed., São Paulo: Saraiva, 2008.

ABELHA RODRIGUES, Marcelo. Manual de direito ambiental e legislação aplicável, São Paulo: Max Limonad, 1999.

FRANCO, José Gustavo de Oliveira. Direito Ambiental - Matas Ciliares, Conteúdo Jurídico e Biodiversidade, Curitiba: Juruá, 2009.

FREITAS, Rafael Véras de. A concessão de florestas e o desenvolvimento sustentável, in Revista de Direito Público da Economia - RDPE, Belo Horizonte, ano 7, n. 26, abr.jun. 2009, p. 107-133.

GASPARINI, Diogenes. Direito Administrativo, São Paulo: Saraiva, 2008.

GODOY, Amália Maria Goldberg. A gestão sustentável e a concessão das florestas públicas. Revista de Economia Contemporânea, Rio de Janeiro, 10(3), p. 631-654, set./dez. 2006.

GUEDES, Alexandre de Matos. A concretização da Reserva Legal via de Ação Civil Pública proposta em face de Tabeliães de Registro de Imóveis, in Anais do $3^{\circ}$ Congresso Internacional de Direito Ambiental, 30 de maio a 02 de junho de 1999: a proteção jurídica 
das florestas tropicais, BENJAMIN, Antonio Herman de Vasconcellos e. São Paulo: IMESP, 1999. p. 17-26.

GONÇALEZ, Nara Maria Esteves Fonseca et al. Contribuição da legislação florestal francesa para a legislação brasileira, Brasília a. 43, nº 169, jan./mar. 2006, p. 265-276.

GONZÁLEZ, Moisés Villalba. BACHA, Carlos José Caetano. As Políticas Florestais do Brasil e Paraguai, in Teoria e Evidência Econômica, Passo Fundo, v. 14, n. 28, p. 37-56, maio 2007.

GRANZIERA, Maria Luiza Machado. Mecanismos de efetividade da lei sobre florestas públicas, in Revista de Direito Ambiental, ano 13, n. 49, jan.-mar./2008, p. 201-216.

IBGE - Fundação Instituto Brasileiro de Geografia e Estatística, Manual Técnico da Vegetação Brasileira, Rio de Janeiro: IBGE, 1992, disponível em http://biblioteca.ibge.gov.br/visualizacao/monografias/GEBIS\%2020RJ/ManuaisdeGeocie ncias/Manual\%20Tecnico\%20da\%20Vegetacao\%20Brasileira\%20n.1.pdf acesso em 17.05.2009

JUSTEN FILHO, Marçal. Curso de Direito Administrativo, São Paulo: Saraiva, 2005. ; O Estatuto da Microempresa e as Licitações Públicas, São Paulo: Dialética, 2007. , Comentários à Lei de Licitações e Contratos Administrativos, São Paulo: Dialética, 2008.

LEUZINGER, Márcia Dieguez. Natureza e Cultura: Unidades de Conservação de Proteção Integral e Populações Tradicionais Residentes, Curitiba: Letra da Lei, 2009.

MACHADO, Paulo Affonso Leme. Direito Ambiental Brasileiro, $15^{\mathrm{a}}$ ed., São Paulo: Malheiros, 2007. , Reserva Legal Florestal, in Revista de Direitos Difusos, São Paulo: ADCOAS, ano VI, vol. 31, maio - jun. 2005, p. 07-17. 
MAGNANI, Italo. Beni Pubblici, Problemi teorici e di gestione. Milão: Franco Angeli Editore, 1974.

MARQUES, Benedito Ferreira. Nuanças de agrariedade nas concessões de florestas públicas, in Revista de Informação Legislativa, Brasília, ano 45, n 177, jan.-mar./2008, p. 159-170.

MARQUES NETO, Floriano Peixoto de Azevedo. O Regime Jurídico das Utilidades Públicas: função social e exploração econômica dos bens públicos. São Paulo, 2008, Tese de livre docência, Data de defesa 02.10.2008, Faculdade de Direito da Universidade de São Paulo, 539 p.

MARRARA, Thiago. Bens Públicos Domínio Urbano Infra-estrutura. Belo Horizonte: Editora Fórum, 2007.

MASAGÃO, Mário. Curso de Direito Administrativo, São Paulo: Editora Revista dos Tribunais, 1968.

MASCARENHAS, Luciane Martins de Araújo. Desenvolvimento Sustentável, Estudo de Impacto Ambiental e Estudo de Impacto de Vizinhança. Curitiba: Letra da Lei, 2008.

MEDAUAR, Odete. Direito Administrativo Moderno, São Paulo: Editora Revista dos Tribunais, 2001.

MELO, Stela Maria Ramos de. Concessão de Florestas Púbicas, in Biblioteca Digital Fórum de Direito Urbano e Ambiental - FDUA, Belo Horizonte, ano 7, n. 40, jul./ago.2008.Disponível em: <www.editoraforum.com.br/bid/bidConteudoShow.aspx? idConteudo=54702>. Acesso em: 16 julho 2009.

MEIRELLES, Hely Lopes. Direito Administrativo Brasileiro, São Paulo: Malheiros, 1998.

MILARÉ, Edis. Direito do Ambiente, São Paulo: Editora Revista dos Tribunais, 2005.

MORAES, Luís Carlos Silva de. Código Florestal Comentado, São Paulo: Atlas, 2009. 
MORAND-DEVILLER, Jacqueline. Cours de Droit Administratif des Biens, Paris: Montcherestien, $3^{\mathrm{a}}$ ed., 2003.

MOREIRA, Julio da Silveira. A Lei de Florestas Públicas sob o crivo da Política Ambiental do Poder Público, in Revista CEJ, Brasília, Ano XII, n. 43, out./dez. 2008, p. 77-83.

MOREIRA NETO, Diogo de Figueiredo. Curso de Direito Administrativo, Rio de Janeiro: Editora Forense, 2006.

MUKAI, Toshio. Os Contratos de Concessões Florestais, in Boletim de Licitações e Contratos, Editora NDJ Ltda., Ano XIX, nº 10, out. 2006, p. 1019-1024

Licitações nas Concessões Florestais, in Revista JML de Licitações e Contratos, Ano I, nº 02, mar. 2007, p. 18-21

NAPOLITANO, Ângela Aparecida. HAONAT, Ângela Issa. Recomposição Florestal em APPs pelo Poder Público: Análise do Artigo 18 do Código Florestal, in Revista de Direitos Difusos, São Paulo, ano VI, vol. 31, maio-jun. 2005, p. 1126-137

NUSDEO, Ana Maria de Oliveira. Servidão Florestal para fins de compensação de Reserva Legal: instrumento de incentivo à proteção florestal? in Revista Brasileira de Direito Ambiental, São Paulo: Editora Fiúza, v. 48, 2007, p. 30-45

PARADA, Ramon. Derecho Administrativo III Bienes Públicos Derecho Urbanístico, Madrid, Barcelona: Marcial Pons, Ediciones Jurídicas y Sociales, S.A., 2000.

PEREIRA, Osny Duarte. Direito Florestal Brasileiro - Ensaio, Rio de Janeiro: Editor Borsoi, 1950.

PEREIRA, Polyana Faria. SCARDUA, Fernando Paiva. Espaços Territoriais Especialmente Protegidos: conceito e implicações jurídicas, in Ambiente \& Sociedade, Campinas, v. XI, n. 1, p. 81-97, jan.-jun. 2008 
PIRES, Luis Manuel Fonseca. Regime Jurídico das Licenças, São Paulo: Quartier Latin, 2006.

PIVA, Rui Carvalho. Bem ambiental, São Paulo: Max Limonad, 2000.

PRADO, Luiz Regis. Crimes contra o ambiente, São Paulo, Revista dos Tribunais, 1998.

RIBEIRO, Mauricio Portugal. PRADO, Lucas Navarro. Comentários à Lei de PPP Parceria Público-Privada, Fundamentos Econômico-Jurídicos, São Paulo: Malheiros, 2007.

RINHEL, Ricardo Domingos. Direito ambiental: incidência do percentual da área de preservação permanente na reserva florestal legal, Revista de Direito Ambiental, n. 40, out.-dez./2005, p. 163-185.

RUFINO, Gilberto D’Ávila. Direito Florestal da Amazônia (uma análise do regime florestal e suas implicações fundiárias), in Anais do $3^{\circ}$ Congresso Internacional de Direito Ambiental, 30 de maio a 02 de junho de 1999: a proteção jurídica das florestas tropicais, organizado por Antônio Hermann de Vasconcelos e Benjamin, São Paulo: IMESP, 1999, p. $141-164$

SALGE JR., Durval. Instituição do bem ambiental no Brasil, pela Constituição Federal de 1988. Seus reflexos jurídicos ante os bens da União. São Paulo: Editora Juarez de Oliveira, 2003.

SANTOS, Márcia Walquiria Batista dos. Licença Urbanística, São Paulo: Malheiros, 2001.

SANTOS, Saint-Clair Honorato. Direito Ambiental - Unidades de Conservação, Limitações Administrativas. Curitiba: Juruá, 2008.

SILVA, Américo Luís Martins da. Direito do Meio Ambiente e dos Recursos Naturais, Vol. 02, São Paulo: Editora Revista dos Tribunais, 2005. 
SILVA, José Afonso da. Direito Ambiental Constitucional, $3^{\text {a }}$ ed., São Paulo: Malheiros Editores, 2000.

SILVA, Vicente Gomes da. Aspectos Legais sobre a Concessão de Florestas Públicas, in Fórum de Direito Urbano e Ambiental - FDUA, Belo Horizonte, ano 5, n. 26, p. 3153 3156, mar./abr. 2006.

SIQUEIRA, Antonio Benedito. Produção Florestal Empresarial e Associativa, Análise e Contextualização Macroeconômicas, Curitiba: Juruá, 2009.

SIRVINSKAS, Manual de Direito Ambiental, 6ª ed., São Paulo: Saraiva, 2008.

SOUTO, Marcos Juruena Villela. Direito Administrativo das Concessões, Rio de Janeiro: Lumen Juris, 2004.

SOUZA, Deoclides Ricardo et al. Ciclo de Corte Econômico Ótimo em Floresta Ombrófila Densa de Terra Firme sob Manejo Florestal Sustentável, Amazônia Oriental, in Revista Árvore, vol. 28, 2004, n 5, Viçosa/MG, p. 681-689

STRUCHEL, Andréa. SERVILHA, Élson Roney. O Direito, as Leis e a Gestão das Florestas, in Revista de Direito Ambiental, ano 12, n. 46, p. 17-40, abr.-jun./2007.

VIRGA, Pietro. Diritto Amministrativo, Milão: Giuffrè Editore, 1983.

ZANETTI, Eder. Certificação e Manejo de Florestas Nativas Brasileiras, Curitiba: Juruá, 2007. , Meio Ambiente, Setor Florestal. Curitiba: Juruá, 2009. 